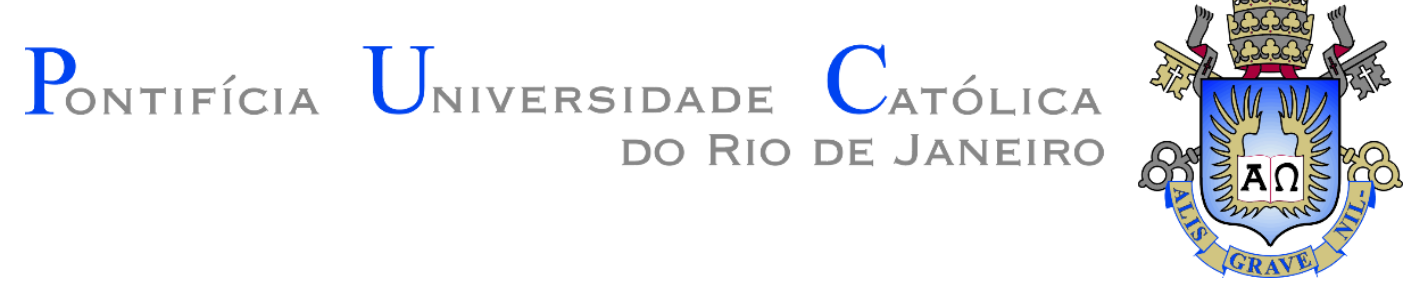

Leonardo Henrique Piacente

\title{
A COMPARAÇÃO DA ECLESIOLOGIA DE IRINEU DE LIÃO COM A LUMEN GENTIUM
}

\section{Tese de Doutorado}

Tese apresentada como requisito parcial para obtenção do grau de Doutor em Teologia Sistemático-Pastoral, pelo Programa de Pós-Graduação em Teologia, do Departamento de Teologia da PUC-Rio.

Orientador: Prof. Dr. Pe. André Luiz Rodrigues da Silva

Rio de Janeiro

Fevereiro de 2021 


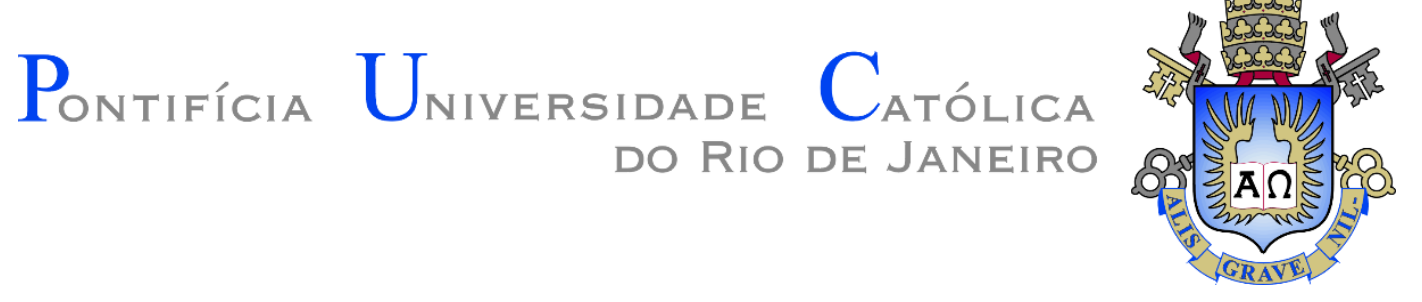

Leonardo Henrique Piacente

\section{A comparação da eclesiologia de Irineu de Lião com a Lumen gentium}

Tese apresentada como requisito parcial para obtenção do grau de Doutor pelo Programa de PósGraduação em Teologia, da PUC-Rio. Aprovada pela Comissão Examinadora abaixo assinada.

Prof. Pe. André Luiz Rodrigues da Silva

Orientador

Departamento de Teologia - PUC-Rio

Prof. Pe. Everaldo Bon Robert Instituto Eclesiástico de Filosofia e Teologia Santo Tomás de Aquino

Prof. Pe. Paulo Sérgio Lopes Gonçalves

PUCCAMP

Prof. Pe. Antonio Luiz Catelan Ferreira

Departamento de Teologia - PUC-Rio

Prof. Pe. Abimar Oliveira de Moraes Departamento de Teologia - PUC-Rio 
Todos os direitos reservados. A reprodução, total ou parcial do trabalho é proibida sem autorização da universidade, do autor e do orientador.

\section{Leonardo Henrique Piacente}

Cursou pós-graduação em Ciências da Religião pela PUC Campinas, obtendo o título de Mestre em 2017. Graduou-se em Teologia pela PUC Campinas em 2007. Filosofia pela UNICAMP (Universidade Estadual de Campinas) em 2003. Participou de diversos congressos na área de Teologia e Ciências da Religião. É professor do Departamento de Teologia da PUC Campinas.

Ficha Catalográfica

Piacente, Leonardo Henrique

A comparação da eclesiologia de Irineu de Lião com a Lumen gentium / Leonardo Henrique Piacente; orientador: André Luiz Rodrigues da Silva. - 2021. 222f.; $30 \mathrm{~cm}$

Tese (doutorado)-Pontifícia Universidade Católica do Rio de Janeiro, Departamento de Teologia, 2021.

Inclui bibliografia

1. Teologia - Teses. 2. Irineu de Lião. 3. Lumen gentium. 4. Eclesiologia. 5. Retorno às fontes. 6. Concílio Vaticano II. I. Silva, André Luiz Rodrigues da. II. Pontifícia Universidade Católica do Rio de Janeiro. Departamento de Teologia. III. Título.

CDD: 200 
Para meus pais Sebastião e Meires, pelo testemunho de fé.

Para a comunidade São Gabriel, pela vivência da fé. 


\section{Agradecimentos}

O presente trabalho foi realizado com apoio da Coordenação de Aperfeiçoamento de Pessoal de Nível Superior - Brasil (CAPES) - Código de Financiamento 001.

Ao meu orientador Prof. Dr. Pe. André Luiz Rodrigues da Silva pela atenção, dedicação e parceria.

Ao CNPq e à PUC-Rio, pelos auxílios concedidos, sem os quais este trabalho não poderia ter sido realizado.

Ao Prof. Dr. Pe. Abimar Oliveira de Moraes por me acolher na PUC-Rio.

Aos meus amigos Pe. Guilherme, Pe. Everaldo, José, Marcelo, Alexandre e Cristiano pelas conversas, pesquisas, sugestões e partilhas.

Ao Prof. Dr. Pe. Paulo Sérgio Lopes Gonçalves pelo encorajamento e indicação para esta pesquisa.

À Pontifícia Universidade Católica de Campinas e a Faculdade de Teologia pelo incentivo a esta pesquisa.

Aos professores que participaram da Comissão examinadora.

A todos os professores e funcionários do Departamento de Teologia pelos ensinamentos e pela ajuda.

A todos os amigos e familiares que de uma forma ou de outra me estimularam ou me ajudaram.

À Paróquia São Miguel Arcanjo, em Sumaré, pela paciência e incentivo nos estudos. 


\section{Resumo}

Piacente, Leonardo Henrique. A comparação da eclesiologia de Irineu de Lião com a Lumen gentium. Rio de Janeiro, 2021, 222 p. Tese de Doutorado - Departamento de Teologia, Pontifícia Universidade Católica do Rio de Janeiro.

A comparação da eclesiologia de Irineu de Lião com a Lumen gentium surge no contexto do movimento de retorno às fontes cristãs nos séculos XIX e XX. O Concílio Vaticano II foi influenciado por este movimento no seu processo de aggiornamento da Igreja no mundo moderno. A nova perspectiva teológica, ainda em construção, influenciou o Concílio Vaticano II e as discussões eclesiológicas, tanto no que se referia à compreensão sobre Igreja quanto à sua atuação e presença no mundo. Tudo isso ficou mais notório com a elaboração da Constituição Dogmática Lumen gentium. De modo especial, Irineu de Lião, bispo e mártir do século II, surge como uma das fontes para este retorno na Lumem gentium que atesta duas citações diretas entre as cinco referências feitas ao texto dele em todo texto conciliar. O bispo de Lião não se incumbe de escrever um tratado teológico, na Adversus haereses e na Epideixis, mas se dedica a defender a fé cristã, que estava se emancipando das comunidades judaicas e ganhando sua autonomia de doutrina, de ensinamento e de culto. Paralelamente a este processo de emancipação crescem outras doutrinas diferentes no seio do cristianismo como foi o caso das doutrinas gnósticas. Para Irineu o conhecimento da verdade é a doutrina que a Igreja recebeu e ensina. Portanto, a agregação a Cristo necessita do conhecimento claro do que é a regula fidei, que norteará a compreensão das Sagradas Escrituras, ordenará o verdadeiro culto a Deus e conduzirá o fiel a testemunhar a presença de Cristo no mundo. A teologia sobre a Igreja em Irineu de Lião não se encontra sistematizada em seus livros, mas aparece em várias partes dos seus escritos enquanto formula suas denúncias e refutações. No entanto, para o bispo de Lião, a Igreja é obra de Deus, que criou o ser humano no seu amor de Pai, e como este se perdeu, enviou o seu Filho para recapitular toda a criação e reunir um novo povo, que ouvisse a sua voz e se voltasse para ele. O ressourcement, por mais que utilizasse de novas metodologias para a construção do pensamento teológico e o ensino de teologia, muitos dos padres conciliares ainda carregavam um modelo manualístico e indireto de abordagem teológica. Portanto, ao comparar o pensamento eclesiológico de Irineu com o desenvolvido 
na Lumen gentium, busca-se tanto as referências que estão no texto conciliar quanto as múltiplas concepções de Igreja que surjam por uma análise comparativa, para assim perceber como o modelo eclesiológico do início do cristianismo possibilita uma compreensão maior e mais profunda de um texto contemporâneo.

\section{Palavras-chave}

Irineu de Lião; Lumen gentium; eclesiologia; retorno às fontes; Concílio Vaticano II. 


\section{Abstract}

Piacente, Leonardo Henrique. The comparison of the Irenaeus of Lyon's ecclesiology with the Lumen gentium. Rio de Janeiro, 2021, 222 p. Doctoral Thesis - Department of Theology, Pontifical Catholic University of Rio de Janeiro.

The comparison of the Irenaeus of Lyon's ecclesiology with the Lumen gentium arises in the context of the return to the Christian Sources in the nineteenth and twentieth centuries. This move had a capital influence in the Second Vatican Council concerning the process of aggiornamento of the Church in the modern world. In this regard, the fresh theological perspective, that was still growing, had an impact both in the ecclesiological discussions and the comprehension about the presence and action of the Church in the world. Furthermore, this whole set has increased in importance through the devising of the Dogmatic Constitution Lumen gentium. Particularly, Irenaeus, bishop of Lyon and martyr of the second century, emerges as a central source for the Lumen gentium since the Constitution includes five references of his writings, two of which are direct quotes. Both in Adversus haereses and Epideixis, the bishop of Lyon doesn't aim to write a theological treatise. Instead of that, his target is to defend the Christian faith, which was emancipating from the Jewish communities and achieving autonomy in the doctrine, the teachings, and the way of cult. In parallel with this emancipation process, different doctrines gain ground within Christianity, as, for example, the gnostic ones. However, according to Irenaeus, the only knowledge of the truth comes from the doctrine which the Church holds and teaches. As a result, for someone to belong to Christ it is mandatory to clearly know the regula fidei, which instructs about the comprehension of the Holy Scriptures, organizes the real God's cult, and guides the devotee to testify Christ's presence in the world. There isn't a systematic Theology about the Church in Irenaeus of Lyon's works, but this matter is recorded in many of his complaints and denials. It can be noticed by the fact that, to him, the Church is God's work. As the human being got apart from the Father's love, God has sent his own Son to recapitulate the whole creation and gather a New People, that could hear his voice and turn back towards him. Despite the ressourcement has applied new methodologies to build up theological thinking and to teach Theology, many Council Fathers were still used to an indirect theological approach, based on the 
use of handbooks. Therefore, comparing the Irenaeus' ecclesiology to the one developed in Lumen gentium is an assignment that requires research both in the references of the conciliar text and the multiple conceptions of Church collected through analysis. Thus, it is possible to develop a deeper knowledge of a contemporary text in light of an ecclesiological model from the beginning of Christianity.

\section{Keywords}

Irenaeus of Lyon; Lumen gentium; ecclesiology; return to the Sources; II Vatican Council. 
Sumário

1. Introdução

2. Fontes patrísticas e bíblicas

2.1. Fontes patrísticas dos séculos I-II: termos "assembleia" e "agregação"

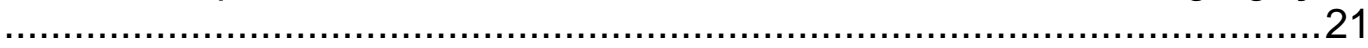

2.1.1. A ekklesía nas Sagradas Escrituras ..........................................21

2.1.1.1. A ekklesía no Antigo Testamento: cerne da comunidade cristã ..21

2.1.1.2. A ekklesía dos crentes em Cristo: Novo Testamento ...................24

2.1.2. Clemente Romano................................................................ 31

2.1.3. Inácio de Antioquia ........................................................ 35

2.1.4. Hermas ............................................................................... 40

2.1.5. Justino de Roma.............................................................. 44

2.1.6. Melitão de Sardes.................................................................. 48

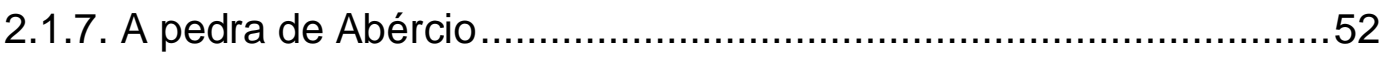

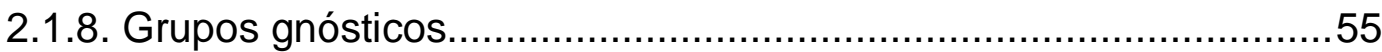

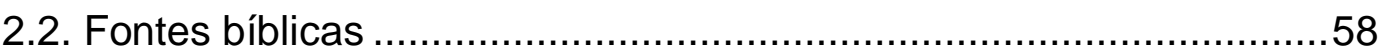

2.2.1. As Sagradas Escrituras na obra de Irineu de Lião ........................58

2.2.2. As referências bíblicas à Igreja ..............................................65

3. A ortodoxia de Irineu de Lião............................................................. 75

3.1. A hierarquia do Pleroma gnóstico.............................................. 76

3.1.1 A gnose valentiniana de Ptolomeu, um modelo de estudo ..............76

3.1.2. A estrutura hierárquica do Pleroma: superioridade e inferioridade. 87

3.2. A ortodoxia de Irineu como chave de eclesiologia ..........................92

3.2.1. Os escritos de Irineu de Lião ................................................92

3.2.2. A eclesiologia na Adversus haereses e na Epideixis................... 101

3.2.2.1. A Igreja e suas características............................................ 102

3.2.2.2. A importância do batismo ................................................. 116

3.2.2.3. A regula fidei..................................................................... 121

3.2.2.4. A atuação da Igreja ........................................................ 124

3.2.2.5. A Tradição Apostólica............................................................129

3.2.2.6. A sucessão apostólica e os ministérios ..................................132

3.2.2.7. A Virgem Maria no mistério da recapitulação de Jesus Cristo ..135

4. A Lumen gentium e a eclesiologia de Irineu de Lião ..........................142

4.1. O retorno às fontes e sua influência no Concílio Vaticano II ............ 142

4.2. A Constituição Dogmática Lumen gentium.................................147

4.3. A Lumen gentium e a eclesiologia de Irineu de Lião .......................151

4.3.1. O mistério da Igreja ........................................................ 151

4.3.2. O Povo de Deus ...................................................................... 163 


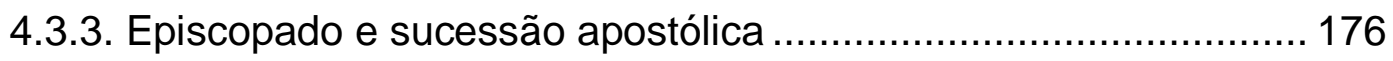

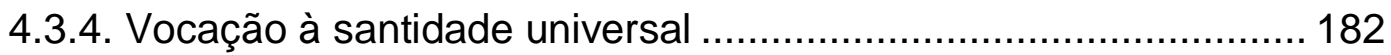

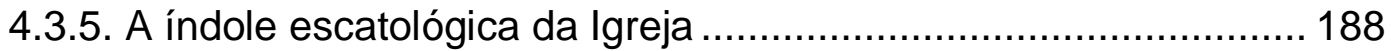

4.3.6. A bem-aventurada Virgem Maria no mistério de Cristo e da Igreja 190

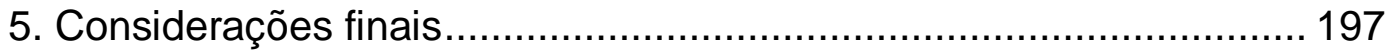

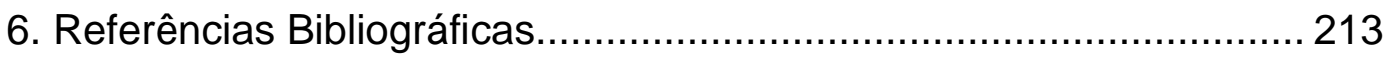




\section{1. Introdução}

O movimento de retorno às fontes cristãs - ressourcement - adentrou o Concílio Vaticano II por dois caminhos. O primeiro foi pelos teólogos que nos séculos XIX e XX discutiam e propunham novas metodologias teológicas para um diálogo mais aberto com as ciências modernas e com aquelas epistemologias que outrora estavam sendo desenvolvidas. O segundo caminho foi introduzido pelo papa João XXIII que, no discurso de abertura do Concílio, exortou os padres conciliares sobre a necessidade do depósito da fé ser fielmente respeitado, aprofundado e exposto segundo as exigências daquela época ${ }^{1}$.

A nova perspectiva teológica, ainda em construção, influenciou o Concílio Vaticano II e, de modo especial, as discussões eclesiológicas, tanto no que se referia à compreensão sobre Igreja quanto à sua atuação e presença no mundo. Tudo isso ficou mais notório com a elaborção da Constituição Dogmática Lumen gentium, não seguindo os parâmetros do Concílio Vaticano I como estava presente no primeiro esquema De Ecclesia, rejeitado pelos padres conciliares no primeiro período, que assumiriam uma nova visão teológica e novos métodos. De certo o retorno às fontes cristãs patrísticas lançaram as bases de fundamentação para uma nova forma de compreender a fé e o modo de vida das primeiras comunidades cristãs.

De modo especial, Irineu de Lião, bispo e mártir do século II, surge como uma das fontes para este retorno na Lumen gentium que atesta duas citações diretas entre as cinco referências feitas ao texto dele em todo texto conciliar.

Entre os Padres da Igreja, Irineu se destaca por assumir uma posição de intermédio entre os escritos pastorais-catequéticos e o surgimento das escolas teológicas de grande relevância nos séculos III e IV. O bispo de Lião não se incumbe de escrever um tratado teológico, mas se dedica a defender a fé cristã, que estava se emancipando das comunidades judaicas e ganhando sua autonomia de doutrina, de ensinamento e de culto. Paralelamente a este processo de

\footnotetext{
${ }^{1}$ JOÃO XXIII, Discurso de sua Santidade papa João XXIII na abertura do SS. Concílio.
} 
emancipação crescem outras doutrinas diferentes no seio do cristianismo como foi o caso das doutrinas gnósticas.

Oriundos de fontes diversas, os gnósticos encontraram nas comunidades cristãs um campo fértil e amplo para o desenvolvimento de suas teorias e doutrinas. Não que tenham trazido um conjuto de propostas prontas e inserido dentro do movimento cristão, mas se desenvolvendo conjuntamente com o cristianismo. Os cristãos organizavam a vida das comunidades, a doutrina, os textos sagrados e formas de culto, reunindo e agregando as pessoas em torno do Cristo. Os gnósticos, com uma perspectiva filosófica dualista, se baseavam em uma compreensão mistérica da realidade e em um culto esotérico. Ambos encontraram um ponto de convergência, não intencional, mas ocasional, na interpretação dos textos bíblicos da tradição judaica e daqueles textos que posteriormente seriam selecionados como canônicos pela literatura cristã. Além disso, o que agregava ambos os grupos era a consciência de não pertencer a este mundo, no qual não eram aceitos, pois não cultuavam os deuses do Império Romano, e também, respeitando as devidas compreensões, tinham uma hierarquia de valores diversa do ambiente em que estavam. No entanto o que conjugava os dois grupos era a confiança no advento de um reino definitivo no céu e a não pertença a este mundo.

Como o cristianismo ainda vivia um processo de emancipação do judaísmo e de compreensão da sua presença neste universo helenizado, ao radiografar de modo genérico tal contexto, as fontes cristãs mais antigas acabaram revelando um processo multicultural e polivalente, no que diz respeito às tradições e informações transmitidas. Em cada região e em cada comunidade os cristãos construíam uma forma peculiar de se inserir nas realidades diversas, desde como saber discernir quais eram as escrituras corretas, a como proceder nas reuniões de culto ao Senhor, como transmitir seus conhecimentos sagrados, como acolher novos irmãos e irmãs para a comunidade e como agregarem novos membros ao Corpo de Cristo.

Irineu de Lião, oriundo do cristianismo asiático e marcado por suas tradições e cultura, se insere numa perspectiva de comunhão entre as igrejas cristãs, indo, ainda como jovem, a Roma na companhia de Policarpo, bispo de Esmirna, para resolver uma dissensão entre a igreja de Roma e as igrejas asiáticas. Posteriormente aparece na Gália, num período de perseguição aos cristãos de Lião 
e Viena, levando as atas dos mártires a Roma em um ato chancelado pela comunidade cristã gaulesa que confia-lhe tal tarefa por ser um ilustre presbítero. Sucessivamente surge como bispo das igrejas da Gália.

Seu escrito maior, Adversus haereses, tem como objetivo, segundo o próprio bispo de Lião, “apresentar [ao caríssimo amigo] o maior número possível de subsídios para contrabater os hereges, converter os que se afastaram e reconduzilos à Igreja de Deus"2. Irineu compreende como heresia as doutrinas gnósticas, marcionitas, valentinianas se espalharam pelas igrejas da Gália. Ademais, na sua consciência de conduzir e pastorear o próprio rebanho de fiéis conforme lhe fora incumbido, também se empenha em confirmar os neófitos para que se mantivessem firmes na fé que tinham recebido de maneira intacta da Igreja, para que não se deixassem corromper pelos que tentavam ensinar o erro para afastá-los da verdade.

Para o bispo de Lião o conhecimento da verdade, ou seja, da doutrina que a Igreja recebeu e ensina, juntamente com a denúncia da falsa doutrina, agrega na comunidade os que realmente se deixam conduzir pelo Senhor. A adesão à comunidade de fé não se dá apenas pelo batismo, já que os gnósticos não somente batizam, mas também participam das eucaristias nas comunidades cristãs. Portanto, a agregação a Cristo plenamente necessita do conhecimento claro do que é a regula fidei, que norteará a compreensão das Sagradas Escrituras, ordenará o verdadeiro culto a Deus e conduzirá o fiel a testemunhar a presença de Cristo no mundo.

A teologia sobre a Igreja em Irineu de Lião não se encontra sistematizada em seus livros, mas aparece em várias partes dos seus escritos enquanto formula suas denúncias e refutações. No entanto, é possível perceber que, para o bispo de Lião, a Igreja é obra de Deus, que criou o ser humano no seu amor de Pai, e como este se perdeu, enviou o seu Filho para recapitular toda a criação e reunir um novo povo, que ouvisse a sua voz e se voltasse para ele.

O ressourcement, por mais que utilizasse de novas metodologias para a construção do pensamento teológico e o ensino de teologia, tanto os padres conciliares como muitos peritos envolvidos no Concílio ainda carregavam um modelo manualístico e indireto de abordagem teológica. Portanto, esta pesquisa,

\footnotetext{
${ }^{2}$ IRINEU de Lião, Adversus haereses V, prefácio.
} 
ao comparar o pensamento eclesiológico de Irineu com o desenvolvido na Lumen gentium, busca tanto as referências que estão no texto conciliar quanto as múltiplas concepções de Igreja que surjam por uma análise comparativa, para assim perceber como o modelo eclesiológico do início do cristianismo possiblita uma compreensão maior e mais profunda de um texto contemporâneo.

Para tanto na abordagem da Lumen gentium foi apresentado o universo histórico da composição do texto e suas principais contribuições para uma nova compreensão da Igreja. De certo, como afirmou o papa Paulo VI, o intuito dos debates conciliares era dar respostas a uma Igreja inserida na realidade e não fora dela. A pastoralidade deveria conduzir os debates para que pudessem compreender a missão da comunidade eclesial e assim chegar à definição eclesiológica.

A presente pesquisa tem o objetivo de estudar a semelhança do pensamento de Irineu de Lião, principalmente sua compreensão sobre a Igreja, com a eclesiologia do Concílio Vaticano II, na constituição dogmática Lumen gentium.

O objeto material desta pesquisa é a teologia sobre a Igreja no seu surgimento nos séculos I e II e no seu desenvolvimento na contemporaneidade.

O objeto formal será a investigação da obra de Irineu para compreender a eclesiologia presente no pensamento do autor de modo que nos permita uma análise da eclesiologia do Concílio Vaticano II na perspectiva de retorno às fontes cristãs.

A metodologia utilizada na pesquisa é de acesso às fontes comparadas, com especial dedicação à abordagem dos textos anteriores a Irineu, para percorrer o caminho da compreensão da Igreja até chegar nas duas obras do bispo de Lião Adversus haereses e Epideixis. Ao tratar da Lumen gentium, o estudo se concentra nos antecedentes históricos e teológicos, e no desenvolvimento da teologia dos padres conciliares. Finalmente, a investigação propõe a comparação das duas abordagens eclesiológicas. Sendo que os elementos eclesiológicos inerentes a Irineu de Lião são colocados juntos aos elementos da Lumen gentium num processo de correlação, no qual a teologia irineana ganha maior destaque.

A relevância da presente pesquisa se propõe em algumas premissas. Primeiramente porque os debates sobre a compreensão da Igreja com sua presença e atuação na realidade é sempre uma discusão atual a partir da Constituição Dogmática Lumen gentium dando origem, com sua proposta de aggiornamento, a 
muitas linhas de pesquisa e estudos sobre a Igreja. Em segundo lugar, o movimento de ressourcement convocou a Igreja a mergulhar no arcabouço da sua história e no desenvolvimento do pensamento teológico para alcançar uma compreensão mais profunda e viva de si mesma. Em terceiro e último lugar, Irineu de Lião por estar inserido num contexto cultural bastante característico não somente por causa da emancipação das comunidades cristãs, mas também por causa do aparecimente de interpretações errôneas da fé que surgiam dentro das comunidades cristãs - apresenta um conteúdo eclesiológico plausível ao interno da sua refutação contra as controvérsias. A originalidade do pensamento irineano se torna uma importante fonte e que em muito contribui para a compreensão da fé cristã nos tempos atuais.

O caráter inovador da pesquisa está no fato de relacionar dois temas estudados separadamente e não no seu conjunto. No mesmo sentido destaca-se o propósito de sistematizar o pensamento irineano sobre a Igreja à luz dos resultados que foram alcançados com o retorno às fontes durante o Concílio Vaticano II. Sobre o estudo da eclesiologia presente na teologia de Irineu de Lião foram encontradas as seguintes iniciativas: L. Spikowski, La doctrine de l'Eglise dans Saint Irénée, 1926, tese de doutorado, apresenta um abordagem da obra irineana fundamentando a visão eclesiológica do Concílio Vaticano I; G. Jossa, Regno di Dio e Chiesa. Ricerche sulla concezione escatológica ed ecclesiologica dell'Adversus haereses di Ireneo di Lione, publicado em 1970, em que se aborda o pensamento eclesiológico de Irineu de Lião a partir da organização em três estudos sobre a perspectiva da Igreja: Povo de Deus, Corpo de Cristo e Mãe dos crentes. Mesmo publicado seis anos após a promulgação da Lumen gentium não toca nas discussões conciliares. O artigo de G. Laiti, La Chiesa nell'economia di Dio secondo Ireneo di Lione, 2005, mostra diversas abordagens e imagens da Igreja na obra Adversus haereses de Irineu de Lião. Este artigo está inserido no livro Consonantía salutis, studi su Ireneo di Lione, fruto de diversas pesquisas e reflexões sobre a teologia de Irineu de Lião.

Em virtude da escassez de pesquisas específicas na eclesiologia irineana, alguns autores que tratam da teologia de Irineu mais aprofundadamente foram importantes para a pesquisa: A. Benoit, Saint Irénée, introduction a l'étude de sa théologie, 1960; J. Faus, Carne de Dios, significado salvador de la Encarnaión en la teologia de san Ireneo, 1969; J. Fantino, La thélogie d'Iréné, 1994; B. Sesboüé, 
Tout récapituler dans le Christ, 2000; E. Osborn, Irenaeus of Lyons, 2001. Além da monumental obra de A. Orbe, com inúmeros livros, comentários e artigos sobre Irineu de Lião. É oportuno notar que há uma concentração de artigos sobre Irineu de Lião no período em que Orbe lecionava (de 1948 até 2000) na Universidade Gregoriana de Roma. Contudo, depois de sua morte, há uma escassez de pesquisas nesta área. Destaca-se ainda o fato de que Orbe tenha publicado somente um artigo sobre o tema da eclesiologia no pensamento de Irineu: Ecclesia, sal terrae, según san Ireneo. No decorrer da pesquisa foram descobertos vários artigos sobre a teologia de Irineu em pesquisadores da Université Catholique de Lyon, na França. Alguns, por estarem disponíveis por meios eletrônicos, foram utilizados, mas, na grande maioria, o acesso físico ficou prejudicado por conta da pandemia.

Entre os estudos e publicações mais relevantes sobre a Constituição Dogmática Lumen gentium estão as obras: G. Philips, A Igreja e seu mistério no II Concílio do Vaticano, 1968, na qual o autor, como responsável pela elaboração do esquema que deu origem a Lumen gentium, relata o desenvolvimento histórico e teológico da constituição; um dos textos mais citados nos artigos e livros que se dedicam aos estudos da eclesiologia do Concílio Vaticano II é G. Baraúna, A Igreja do Vaticano II, 1965, uma coletânea de artigos de peritos e padres conciliares, editada para ajudar na compreensão do texto conciliar; S. Noceti e R. Repole, Lumen gentium, 2018, em que jovens teólogos foram convidados a refletirem sobre a Lumen gentium, apresentando o texto conciliar com comentários sobre o seu desenvolvimento histórico e teológico. Ademais, foram utilizados outros diversos artigos e livros sobre a Lumen gentium, no decorrer destes cinqüenta anos de sua promulgação, tanto de teólogos diretamente envolvidos com a eleaboração do texto - Y. Congar, H. De Lubac, J. Ratzinger, J. Daniélou, K. Rahner - como outros teólogos atuais que refletem o desenvolvimento da obra - S. Pié-Ninot, W. Kasper, G. Tangorra, D. Vitali.

Sobre a relação determinada pela comparação entre o pensamento de Irineu de Lião e a Constituição Dogmática Lumen gentium não foram encontradas referências bibliográficas que aludissem a tal paralelo, nem tampouco foram mencionados pesquisas ou teses nos catálogos consultados das Universidades Católicas do Brasil e de Roma. Contudo, foram encontradas algumas teses sobre a teologia de Irineu de Lião: uma sobre a doutrina do Corpo e Sangue de Jesus 
Cristo, no Instituto Patrístico de Roma; doze teses na Pontifícia Universidade Gregoriana de Roma, sendo que em uma delas o autor pesquisou a relação do pensamento de Irineu com o Concílio Vaticano II: A soteriologia ireneana e seu influxo na constituição "Gaudium et spes" como relevância para a acolhida da salvação na alta modernidade, de Geraldo dos Reis Maia, ex-reitor do Colégio Pio Brasileiro em Roma, defendida em 2013 quando ainda era hóspede do Colégio.

Sobre a influência dos Padres da Igreja nos textos do Concílio Vaticano II, de modo especial na Constituição Dogmática Lumen gentium destaca-se D. Gianotti, I Padri dela Chiesa al Concilio Vaticano II: la teologia patrística nella Lumen gentium, 2010. Segundo o autor, este foi o primeiro estudo que pesquisou no texto da Lumen Gentium todas as citações e referências aos Padres da Igreja. Ademais, C. Pietri, L'ecclésiologie patristique et Lumen gentium, 1986, artigo que explicita a utilização dos textos patrísticos durante o Concílio e o conhecimento que os Padres conciliares tinham do mesmo.

Com referência ao movimento teológico pré-conciliar que motivou um processo de retorno às fontes cristãs - medievais e patrísticas - no decorrer da pesquisa algumas obras foram essenciais para sua compreensão: H. Boersma, Nouvelle théologie \& sacramental ontology: a return to mystery, 2009; D. Gianotti, Ressourcement: una teologia dalle fonti, 2012; G. Flynn e P. Murray, Ressourcement: a movement for renewal in twentieth-century catholic theology, 2012.

Em relação aos artigos publicados sobre o pensamento de Irineu e o Concílio Vaticano II, tendo consultados os principais periódicos de teologia no Brasil, pouco foi encontrado sobre o pensamento de Irineu. No entanto, surgem vários comentários aos documentos conciliares, principalmente nos períodos comemorativos da realização do Concílio. Nas consultas realizadas em Roma, nos periódicos da Universidade Gregoriana, no Instituto Patrístico e na Universidade Lateranense, pouco foi encontrado sobre o pensamento do bispo de Lião e o Concílio, ao passo que abundam artigos específicos sobre cada uma das partes desta pesquisa isoladamente.

O percurso desenvolvido na pesquisa apresenta-se como segue: após a Introdução, o segundo capítulo aborda a fontes bíblicas e patrísticas anteriores a Irineu concentrando-se na compreensão primitiva sobre a assembleia e a 
agregação cristã. Partindo do contexto bíblico, diversas compreensões do termo ekklesia são apresentadas conforme a abordagem do Antigo e Novo Testamento.

No terceiro capítulo se estuda o pensamento de Irineu de Lião, presente na Adversus haereses e na Epideixis, sobre os grupos gnósticos e suas teorias denunciadas pelo autor. Mais especialmente se dedica a investigar nos escritro de Irineu sua ortodoxia, tendo como foco principal como constrói e como pensa a eclesiologia.

No quarto momento se analisa o movimento teológico que motivou o retorno às fontes cristãs, que influenciaram o desenvolvimento histórico e teológico da Constituição Dogmática Lumen gentium. A partir daí se desenvolve uma comparação de ambas as abordagens eclesiológicas: Irineu e Lumen gentium, mostrando a influência do pensamento irineano na obra, mas também os limites metodológicos na abordagem das fontes no período conciliar e a prossibilidades de interpretação e aprofundamento eclesiológico atual que esta relação entre as duas abordagens eclesiológicas apresentam.

Em princípio, o projeto de Tese propunha para o título "As raízes patrísticas da Lumen gentium". Contudo, no desenvolvimento da pesquisa, com as leituras e análise dos textos, percebe-se que o tal tema abrangeria toda a patrística cristã, o que o tornaria o trabalho muito extenso e vago. Visto que desde o princípio o objetivo da pesquisa trazia a obra de Irineu e a Lumen gentium como os pontos referenciais, buscou-se fazer com que o tema refletisse com mais precisão aquilo que estava sendo estudado. Por esse motivo, escolhe-se por título da Tese: $A$ comparação da eclesiologia de Irineu de Lião com a Lumen gentium. Ou seja, uma abordagem da eclesiologia patrística de Irineu e seus antecedentes, para então abordar o texto conciliar e comparar a eclesiologia irineana e a conciliar.

Mesmo desenvolvendo a coleta bibliográfica nos anos iniciais da pesquisa, materialmente os textos e os artigos coletados foram os oriundos das bibliotecas das Universidades de Roma, além de livros adquiridos sobre o pensamento de Irineu. Porém os textos que estavam disponíveis nas bibliotecas no Brasil, principalmente na Pontifícia Universidade Católica do Rio de Janeiro, que tratavam dos temas mais ligados ao Concílio Vaticano II e à Lumen gentium, não foram adquiridos de forma mateiral, pois no tempo oportuno poderiam ser requisitados facilmente. Com o encerramento das atividades presenciais em virtude da pandemia e o acesso às bibliotecas fechado, a utilização de muitas 
fontes foi extremamente prejudicado. $\mathrm{Na}$ medida do possível, várias fontes bibliográficas foram utilizadas de forma virtual, somando para a viabilidade de uma reflexão suficientemente fundamentada. 


\section{2. \\ Fontes patrísticas e bíblicas}

2.1.

Fontes patrísticas dos séculos I-II: termos "assembleia" e "agregação"

\subsection{1.}

\section{A ekklesía nas Sagradas Escrituras}

A consciência dos cristãos dos primeiros séculos, como povo reunido pelo Senhor para uma nova e definitiva Aliança, que nasce a partir da Revelação de Jesus Cristo e de sua ressurreição, traz um vínculo fundamental com a descendência de Abraão. Tanto os escritores bíblicos, com uma Revelação imediata, como os propagadores dessa Boa Nova, com uma Revelação continuada, sempre tiveram clareza "que os primórdios da sua fé e eleição já se encontram, segundo o mistério divino da salvação, nos patriarcas, em Moisés e nos profetas" ${ }^{3}$.

Sendo assim, a compreensão de Povo de Deus, como assembleia dos fiéis, ou comunidade reunida no Senhor, entre os cristãos dos dois primeiros séculos, sofre influência da noção teológica do povo da primeira Aliança. Por isso, o Concílio Vaticano II afirmou que é necessário evidenciar que estas comunidades cristãs não nasceram a partir do nada, mas sim estão misteriosamente prefiguradas no Israel do Antigo Testamento e, em continuidade com a missão confiada por Deus aos hebreus, constituem um único Povo de Deus ${ }^{4}$.

\subsubsection{1.}

\section{A ekklesía no Antigo Testamento: cerne da comunidade cristã}

A constituição das comunidades eclesiais veterotestamentárias é muito variada na sua forma de existência e de difícil definição para os nossos tempos, pois está condicionada às diversas experiências de fé, tradições religiosas, fatos

\footnotetext{
${ }^{3}$ CONCÍLIO VATICANO II, Nostra aetate 4.

${ }^{4}$ CONCÍLIO VATICANO II, Lumen gentium 13-16.
} 
históricos e culturas com os quais Israel estabeleceu contato durante seu caminho com o Senhor.

A eclesiologia do Antigo Testamento qualifica as comunidades de fé de diversas formas ${ }^{5}$, no decorrer da história da salvação: povo de Deus, liga de tribos, santo resto, diáspora, comunidade de culto, cidade santa, reino de Davi, os reinos separados de Judá e de Israel, e Reino de Deus. Contudo, mesmo que os autores afirmem que estas formas de existência de Israel sucederam-se historicamente, isso não se deu de maneira continuada e ascendente, mas em muitos momentos a ekklesía veterotestamentária existiu em diversas formas, visto que suas características se entrelaçam numa realidade contínua e essencial. Mas "essa mesma essência não é passível de enquadrar-se numa única fórmula ou até de confinar-se numa única definição" .

Israel, visto como comunidade de $\mathrm{Culto}^{7}$, é a forma da comunidade veterotestamentária que muitos autores acreditam ter sido a que mais claramente deu origem às primeiras comunidades cristãs, ou o modo de ser comunidade mais latente e viva nos inícios do movimento de Jesus e dos seus seguidores. E esta comunidade não representava somente os que ali estavam reunidos, mas todo o povo de Deus disperso, todas as doze tribos, ou seja, era a grande reunião dos irmãos.

Na perspectiva sacerdotal e pós-exílica, a designação dessa comunidade de Culto se dava pelo termo 'eda, que é traduzido como reunião, mas a palavra expressava uma passividade no seu significado. Em contrapartida, na concepção deuteronomista o termo utilizado era qahal, que se traduz por assembleia e denota um sentido ativo. Mesmo tendo traduções um pouco diferentes no grego da Septuaginta, os termos muitas vezes são utilizados como sinônimos.

O termo ${ }^{8}$ hebraico 'eda aparece 225 vezes traduzido na Septuaginta pelo termo grego synagoge e nunca aparece como ekklesía, contudo no grego clássico, o termo synagoge não tem o sentido que os tradutores da Septuaginta quiseram dar, pois designava reuniões cúlticas, ligadas à refeição e aos sacrifícios, e não ao lugar da assembleia, da congregação, do povo que se reúne em torno da tenda da

\footnotetext{
${ }_{6}^{5}$ FÜGLISTER, N., Formas da existência da ekklesia do Antigo Testamento, p. 12-40.

${ }^{6}$ FÜGLISTER, N., Formas da existência da ekklesia do Antigo Testamento, p. 73.

${ }^{7}$ FÜGLISTER, N., Formas da existência da ekklesia do Antigo Testamento, p. 24-28.

${ }^{8}$ SCHILLEBEECKX, E., Por uma Igreja mais humana, p. 60-61; BROW, C.; COENEN, L., ekklesia, p. 984-998.
} 
congregação. “A palavra expressa o conceito de corporeidade, no qual se ressalta não a totalidade dos indivíduos, e, sim, a unidade da comunhão" ${ }^{9}$, sendo assim, o sentido do termo não é só cúltico ou legal, e representa a comunidade como um povo em sua totalidade, que não está preso a uma terra ou território, mas que no deserto caminha em unidade.

Em virtude da obediência à Lei que caracterizava tão fortemente a vida do povo, 'eda não precisa vir acompanhada de qualificações específicas, como qahal, pois essa carrega em si a totalidade semântica que compreende todos os membros do povo, sem sectarismos.

O termo qahal ${ }^{10}$ significa uma convocação para uma assembleia, ato de reunir-se, ajuntamento para revista. Sendo assim, o termo designa desde o ajuntamento para o serviço militar, a reunião para consultas políticas ou audiências jurídicas, até a assembleia para o culto. Na tradução da Septuaginta, o vocábulo qahal é quase sempre traduzido pelo termo grego ekklesía, mas algumas vezes também por synagoge, principalmente no Pentateuco e nos profetas.

Já no livro do Deuteronômio, qahal ganha um sentido cúltico muito significativo, pois representa a congregação do Povo de Deus, reunida para completar a Aliança; uma assembleia especial e solene, que se reúne quando convocada pelo próprio Deus. Por isso, vem seguida de conceitos que a definem, revelando detalhes de sua característica: qahal YHWH $(\mathrm{Nm} \mathrm{16,3)}$ e qahal elohim (Ne 13,1). E esta congregação do Senhor, que aparece 13 vezes no Antigo Testamento (Nm 20,4; Dt 23,2-4, 1Cr 28,8) terá uma grande relevância no Novo Testamento, pois é a forma que mais se aproxima da ekklesía kuriou, ou seja: a Igreja do Senhor.

Portanto, 'eda significa a totalidade da comunidade judaica, é um grupo fixo geralmente definido pela questão do nascimento, diferente de qahal que é a comunidade convocada uma ou outra vez. Enfim, Israel, entendido como comunidade de culto a partir das palavras 'eda e qahal, amadurece o sentido mais profundo da constituição do Povo, entendendo que "Deus que a reuniu e a

\footnotetext{
${ }^{9}$ SCHILLEBEECKX, E., Por uma Igreja mais humana, p. 60.

${ }^{10}$ SCHILLEBEECKX, E., Por uma Igreja mais humana, p. 60-61; BROW, C.; COENEN, L., ekklesia, p. 984-998.
} 
congrega sempre de novo como sua comunidade, nela se presencializa, para se the comunicar pessoalmente por sua Palavra reveladora e seus sinais santificantes"11.

\subsubsection{2.}

\section{A ekklesía dos crentes em Cristo: Novo Testamento}

O termo mais significativo para expressar as comunidades dos crentes em Cristo no Novo Testamento é "a palavra grega ekklesía, utilizada para comunidades domésticas individuais, para as comunidades locais constituídas eventualmente por diversas comunidades domésticas e para todos os crentes em Cristo" $" 12$.

Sua utilização mais remota foi atribuída a Paulo, nas cartas, que ao invés de utilizar a tradução do termo hebraico 'eda, prefere compreender as primeiras comunidades cristãs como o significado de qahal, utilizando para tanto o termo ekklesía $^{13}$. Este tem sua origem na tradução da Septuaginta e também na compreensão que a primitiva comunidade helenista terá sobre si, a partir da missão que Jesus lhe confiou. Contudo, nesta identificação com a ekklesía do Antigo Testamento ${ }^{14}$, os cristãos também se assumem como Povo de Deus ${ }^{15}$, enquanto, aos poucos, esta comunidade nascente vai ganhando características rituais, locais de culto, forma de anúncio e linguagem diferentes do universo judaico, consolidando, assim, uma autonomia do grupo cristão ${ }^{16}$.

No Novo Testamento ${ }^{17}$, é possível encontrar dois aspectos fundamentais da ekklesía, ou seja, a reunião de pessoas e o vínculo comunitário existente entre elas. No primeiro aspecto, utilizando o termo ekklesía juntamente com o genitivo de Deus ou de Cristo, as comunidades crentes assumiram o conceito veterotestamentário (qahal Elohim ou qahal Yahweh), reconhecendo-se como o verdadeiro povo de Deus, ou seja, ekklesía tou Theou, assembleia de Deus, Igreja de Deus, congregação de Deus. Portanto, veem-se convocadas e reunidas por

${ }^{11}$ FÜGLISTER, N., Formas da existência da ekklesia do Antigo Testamento, p. 28.

12 STEGEMANN, E.; STEGEMANN, W., História social do protocristianismo, p. 297.

${ }^{13}$ WIEDENHOFER, S., Eclesiologia, p. 65-70.

14 DANIÉLOU, J., La chiesa dei primi tempi, p. 15-23; BERGER, K., Los primeros cristianos, p. 49-50.

${ }^{15}$ SCHLIER, H., A Eclesiologia do Novo Testamento, p. 126.

${ }^{16}$ GROSSI, V., Linee di ecclesiologia patrística, p. 9-10.

${ }^{17}$ O termo ekklesía não aparece nos Evangelhos, com exceção de Mateus, contudo é citado 114 vezes nos outros escritos do Novo Testamento, sendo que 46 vezes em Paulo e 23 vezes nos Atos dos apóstolos (BROW, C.; COENEN, L., Ekklesía, p. 984-998). 
Deus, como povo que Ele escolheu e congregou para constituir o novo Israel. Dessa forma, os primeiros cristãos "reivindicavam uma origem divina para o surgimento de suas comunidades" $" 18$.

No segundo aspecto, "a palavra ekklesía no Novo Testamento não significa tanto a real reunião dos cristãos, quanto principalmente o grupo cristão em si, quer local, quer espalhado como muitas comunidades domésticas em todo o mundo de

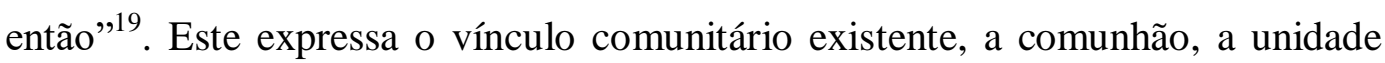
dos crentes em Cristo, que se agregam como novo povo de Deus.

Tendo em vista a busca da compreensão de Igreja nos dois primeiros séculos do cristianismo, também é importante verificar como esse conceito se apresenta nos Evangelhos de Mateus, Lucas, João e em Paulo. Nestes não há um padrão único de definição do que possa ser a ekklesía. Nos vários escritos, são narradas experiências e vivências diversas do sentir e ser Igreja, sempre ligados ao Cristo.

A compreensão eclesial que Mateus tem e vive é a Igreja do Messias Jesus Cristo (Mt 16,18 ekklesía), que não é somente uma realidade prometida por Jesus, mas na qual Ele vive e ocultamente é o seu início. A perspectiva mateana de ekklesía parte do significado semítico de assembleia (qahal) e designa no AT a comunidade do povo eleito. Mas, para Mateus, essa comunidade messiânica tem uma particularidade, mesmo sendo escatológica, começa já na terra sua presença clara, como uma sociedade que tem Pedro como chefe. Porém, este não tem em si a totalidade da Igreja, pois a ekklesía é do mestre Jesus Cristo $^{20}$, e a ela há uma agregação a partir de uma experiência de discipulado.

Ser discípulo não é apenas diferenciar-se da multidão que acorre ao Mestre, mas também é ser companheiro, servidor, confidente e mensageiro de Jesus. Juntos, os discípulos constituem uma comunidade de irmãos, na qual um serve o outro, mesmo ainda conservando a fragilidade humana, marcados pela incompreensão e incompetência ${ }^{21}$. Esse discipulado, no qual a especificação numérica é irrelevante, tem características fundamentais, pois foi chamado pelo Senhor, a exemplo do chamado dos quatro primeiros discípulos (Mt 4,18-22), mas também foi conquistado e motivado por Jesus, em virtude da proximidade do

\footnotetext{
${ }^{18}$ STEGEMANN, E.; STEGEMANN, W., História social do protocristianismo, p. 298.

${ }^{19}$ SCHILLEBEECKX, E., Por uma Igreja mais humana, p. 61.

${ }^{20}$ BERGER, K., Los primeros cristianos, p. 161-162.

${ }^{21}$ SCHLIER, H., A eclesiologia do Novo Testamento, p. 85-86.
} 
Reino de Deus, para formar essa comunidade aberta, uma fraternidade de irmãos e irmãs, na qual desapareceram as diferenças e superioridades (Mt 23,8-10), pois todos são discípulos do mestre Jesus ${ }^{22}$.

A Igreja, para Mateus, reúne todos os povos convocados por Jesus - mesmo que no fim dos tempos todos se reunirão em torno do Filho do Homem (Mt 25,32). Essa reunião acontece agora e em todos os lugares, pois o Emanuel já veio e a reunião já se iniciou. A Igreja é este novo Israel reunido pelo Senhor. São os discípulos e discípulas que o Enviado e Ressuscitado manda à sua frente para anunciar o seu Reino.

Na obra de Lucas, Evangelho e Atos dos apóstolos, a Igreja é obra de Deus, que se concretiza no cumprimento da promessa, em Jesus. Este se revela a todos, judeus e gentios, cumprindo a promessa do Deus de Israel de formar um só povo de Deus. Porém, a experiência com Jesus Cristo ressurreto e vivo é fundante e clara para a formação deste novo povo de Deus, somente os que se deixam iluminar pelo Espírito a compreendem e tornam-se seguidores do Mestre.

Desta forma, os discípulos-apóstolos - Paulo, as mulheres e a multidão dos crentes - vão concretizando o anúncio da ressurreição e o Espírito confirma e consolida em cada pessoa a pertença à comunidade de fé. E em cada ação e anúncio, os seguidores veem se concretizar as promessas de Jesus aos discípulos, “pois o Espírito Santo vos ensinará naquele momento o que deveis dizer" (Lc 12,12). Os sinais que acompanham a pregação manifestam a ação do Espírito, que acompanha a Igreja nascente. Uma característica desta Igreja, significativa para Lucas, é a reunião dos irmãos, a marca da fraternidade: as pessoas reúnem-se em torno da Palavra e escutam o que ela diz (At 13,44) ${ }^{23}$.

Esta forma de assembleia ou reunião aparece, na obra lucana, desde o início da comunidade cristã: mulheres anunciam a ressurreição (Lc 24,9-11), discípulos de Emaús voltam para Jerusalém (Lc 24,33-35), aparição do Ressuscitado aos discípulos reunidos (Lc 24,36-42), substituição de Judas Iscariotes (At 1,12-26), Pentecostes (At 2,1-13), comunidade cristã (At 2,42-47; 4,32-35) e no Templo (At 3,1-9). Essa Palavra que convoca e que reúne os que creem faz com que a própria Palavra cresça. A Igreja é "onde se ouve, aceita e crê nessa Palavra, onde se

${ }^{22}$ SCHILLEBEECKX. E., Por uma Igreja mais humana, p. 120.

${ }^{23}$ DANIÉLOU, J., La chiesa dei primi tempi, p. 10-14; SCHLIER, H., A eclesiologia do Novo Testamento, p. 104. 
realiza a conversão, que é selada pelo batismo, forma-se o discipulado e a fraternidade da Igreja" 24 .

No Evangelho de João, a Igreja ${ }^{25}$ é compreendida não como uma estrutura clara, mas sim como a comunidade daqueles que se relacionam com Jesus Cristo. Nem o termo ekklesía aparece no escrito joanino. Mas a Igreja está claramente presente na obra como um todo, pois ela é a multidão dos fiéis que, em Cristo, compreenderam e acolheram a Boa Nova (Jo 1,12); os que nascem de novo (Jo 3,3); os que creram no nome do Filho de Deus (Jo 3,36); os que se decidem livremente (Jo 6,66). Três perícopes expressam claramente essa adesão ao projeto de Jesus: a videira verdadeira (Jo 15), o Bom Pastor (Jo 10) e Jesus na Samaria (Jo 4). A intrínseca união entre a videira e os ramos é que possibilita a produção de frutos; o cristão que crê em Cristo produz os frutos de vida eterna, pois descobre nele que "sem mim, nada podeis fazer" (Jo 15,5). A permanência no Cristo não se dá somente por decisão do fiel, mas também porque compreende que o Senhor é a comunidade de fé, e a agregação à videira, por parte do ramo, é naturalmente o seu fim (Jo 15,4).

Tendo como perspectiva a profecia de Ezequiel (Ez 34), a perícope do Bom Pastor (Jo 10) traça a unidade entre o Cristo e os fiéis, como o Pastor ao rebanho. As ovelhas reconhecem em Jesus Cristo o verdadeiro pastor. Elas o escutam e seguem; descansam, entram e saem, mas sempre encontram pastagens. A relação de confiança não se dá somente pelo senhorio e a submissão, mas sim porque o Senhor dá a vida pelas suas ovelhas e elas reconhecem nele a sua possibilidade de existência. Há um só rebanho e um só Pastor, cumprindo assim a profecia veterotestamentária. Ao ler a passagem de Jesus pela Samaria, a comunidade de fé compreende que, para constituir uma comunidade de vida com o seu Senhor, é preciso descobrir "que os verdadeiros adoradores adorarão o Pai em espírito e verdade, pois estes são os adoradores que o Pai precisa" (Jo 4,23). Neste ato de adoração, é o homem como tal que volta toda sua vida para relacionar-se com Deus, é sua verdadeira expressão religiosa.

Assim, a comunidade entende uma nova perspectiva de relacionamento com Deus, não mais nos ritos e sacrifícios, mas na vida colocada diante do Senhor ${ }^{26}$,

\footnotetext{
${ }^{24}$ SCHLIER, H., A eclesiologia do Novo Testamento, p. 109.

${ }^{25}$ SCHLIER, H., A eclesiologia do Novo Testamento, p. 110-119.

${ }^{26}$ GROSSI, V., Linee di ecclesiologia patrística, p. 10.
} 
visto que nele encontrou a água da vida (batismo) e a Palavra da verdade (Jesus Cristo). Deste modo, não têm mais sede, pois agregam-se em torno do Messias, que lhes concede um alimento de vida, e dos apóstolos, que comunicam essa vida verdadeira.

Nas cartas paulinas, a designação de Igreja como povo de Deus aparece somente em duas citações do AT (Rm 9,5 e 2Cor 6,16), pois Paulo acredita ser um termo pouco abrangente para a compreensão do que a Igreja é realmente. Para manifestar o sentido mais pleno e solene de povo de Deus reunido, Paulo designa a Igreja como ekklesía tou Theou, termo colhido da tradição veterotestamentária, a partir da tradução da Septuaginta, e também da primitiva comunidade helenista ${ }^{27}$. Tal termo origina-se na tradução da qahal hebraica, que, em Deuteronômio, Crônicas e Salmo, designa o conjunto da comunidade de Israel e sua assembleia. Essa ekklesía tou Theou aparece várias vezes nos escritos paulinos - 1Cor 1,2; 10,32; 11,16.22; 15,9; G1 1,13; 1Ts 2,14; 2Ts 1,4 - e é uma compreensão peculiar de Paulo, pois somente At 20,28, no NT, usará o mesmo termo e sentido paulino: "subentendendo-se a Igreja como povo de Deus reunido, que é agora o povo em Deus Pai e no Senhor Jesus Cristo, ou em Cristo, neste, ou naquele lugar" ${ }^{28}$.

Sendo assim, algumas características desta ekklesía tou Theou podem ser compreendidas na interpretação das epístolas paulinas. Primeiramente, a Igreja de Cristo é claramente a continuação do Povo de Deus no Antigo Testamento, pois na oliveira nobre - Jesus - foi enxertada a oliveira bravia - Israel - $(\mathrm{Rm} 11,17)$, que assume a missão de não mais estar ligado pela circuncisão da carne, mas sim circuncidado no Espírito $^{29}$ (Fl 3,3). Além disso, a Igreja de Deus em Cristo Jesus também é o povo de Deus escatológico, que, reunido, celebrará a sua nova Aliança com Deus. A terceira característica da Igreja, segundo Paulo, é ser local, domiciliar, mas também una. "A una Igreja de Deus aparece em Corinto ou em Roma ou em Tessalônica ou onde quer que seja, na Igreja local correspondente. O uno povo de Deus está de vez em vez presente em cada comunidade local ou domiciliar particular"30.

${ }^{27}$ DE LUBAC, H., Paradosso e mistero della Chiesa, p. 97-98; SCHLIER, H., A eclesiologia do Novo Testamento, p. 126.

${ }^{28}$ SCHLIER, H., A eclesiologia do Novo Testamento, p. 126.

${ }^{29}$ BERGER, K., Los primeros cristianos, p. 117-118.

${ }^{30}$ SCHLIER, H., A eclesiologia do Novo Testamento, p. 128. 
Desta forma, a assembleia reunida localmente representa a sagrada assembleia festiva. Por isso, Paulo nomeia os seus membros (1Cor e Rm), para mostrar quem são os participantes distintos. E estes listados não são somente os destinatários da Carta, mas sim o povo santo, que foi eleito, chamado e reunido para a sagrada assembleia ${ }^{31}$. "Uma igreja [ekklesía], no sentido grego, é, muito concretamente, uma assembleia. Não se trata de assembleias de filósofos, nem de sessões místicas: os cristãos obedecem a uma 'convocação' divina e formam o povo de Deus" ${ }^{32}$. Por último, Paulo compreende a ekklesía como o Israel de Deus, como a reunião dos judeus e gentios num só povo, para os tempos finais, que peregrinam nesta terra como membros da família humana e pertencentes ao mundo político presente, os quais anseiam por viverem a Jerusalém celeste.

Nas cartas aos Efésios e aos Colossenses, Paulo amplia sua compreensão de ekklesía, apresentando a perspectiva da Igreja como o Corpo de Cristo $^{33}$ e Cristo como a cabeça da Igreja. Há uma relação intrínseca entre Cristo e os que estão inseridos nele como membros pela via da Igreja: uma relação essencial, de vida. A Igreja é Cristo no seu corpo. "Essa sobre-ordenação de Cristo ao seu corpo, a Igreja, não se resume, porém em ter o domínio sobre ela, mas em ser Cristo, ainda, como cabeça do corpo, o centro a partir do qual e em direção ao qual o corpo cresce $(\mathrm{Ef} 4,15), 34$.

Além disso, a Igreja Corpo de Cristo remete a uma compreensão de abrangência e união de todos, pois o corpo uno é o corpo unificante que encerra todos. A partir desta perspectiva de unidade do Corpo de Cristo, que é a Igreja, em Rm 12 e 1Cor 12, surge outra forma de compreensão ${ }^{35}$ estabelecida por Paulo, ou seja, os membros deste Corpo de Cristo têm uma relação com seu Senhor e também uma relação entre si, onde o Corpo é a comunidade dos fiéis, uma estrutura social, uma corporação. Desta forma, os membros estabelecem uma relação entre si, pois são dependentes uns dos outros, assim como são responsáveis uns pelos outros.

Este vínculo estabelecido na alegria e no sofrimento, na esperança e na desilusão conduz a vivência fundamental da fé em Jesus Cristo: amando-se uns

\footnotetext{
${ }^{31}$ GROSSI, V., Linee di ecclesiologia patrística, p. 9.

${ }^{32}$ DE LUBAC, H., Paradosso e mistero della Chiesa, p. 97.

${ }^{33}$ DE LUBAC, H., Paradosso e mistero della Chiesa, p. 99-101.

${ }^{34}$ SCHLIER, H., A eclesiologia do Novo Testamento, p. 130.

35 BERGER, K., Los primeros cristianos, p. 94; SCHLIER, H., A eclesiologia do Novo Testamento, p. 131-132.
} 
aos outros $(\operatorname{Rm} 12,3 ; 1$ Cor 12,14; Ef 4,1). Essa mútua relação de amor entre os membros do Corpo de Cristo, que é a Igreja, marca a união e agregação do povo de Deus.

A partir da compreensão paulina de Igreja como o Corpo de Cristo pendente na cruz, surge o questionamento: como esta assembleia de fiéis edifica-se? A Igreja se edifica pelo Evangelho de Cristo, que ela anuncia (1Ts 3,2; 2Ts 1,8; Rm 10,14). “O Evangelho apostólico, anunciado na virtude do Espírito, não só fala sobre o que anuncia, mas faz com que o assunto que atesta possa falar com seu impacto e, nesse sentido, atingir os homens do presente" ${ }^{\text {36 }}$. E este ministério espiritual que Paulo apresenta nas suas cartas (1Cor 12,28) são os dons que o Cristo exaltado derrama sobre a Igreja: apóstolos, profetas e evangelistas, que lançaram os fundamentos de toda a Igreja, bem como pastores e doutores, que continuam a atuar nas comunidades locais ${ }^{37}$.

Além destas duas perspectivas edificantes da Igreja, o anúncio do Evangelho e o ministério, o Apóstolo apresenta outras duas perspectivas fundantes para a edificação da Igreja: o batismo e a ceia do Senhor ${ }^{38}$. Os batizados em Cristo, para Paulo, são os membros do Corpo de Cristo e integrados nesse evento salvífico na morte e ressurreição (Ef 2,5). "Os que foram apropriados a Cristo pelo batismo e admitidos à história salvífica e à dimensão salvífica representam as pedras de que consiste o templo de Deus, o sagrado espaço concreto do Corpo de Cristo, a Igreja"39. E essa construção e estruturação do corpo crucificado de Cristo, pela ação do Espírito, é que concretiza a dimensão salvífica da Igreja na terra, repete-se todas as vezes que os fiéis se reúnem, em assembleia, para a ceia do Senhor, que Paulo designa por eucaristia (1Cor 11,17$34)$.

A compreensão da presença real e oculta de Jesus na eucaristia faz com que a comunidade primitiva se sinta como a continuação da comunhão de vida com Jesus. Os cristãos descobrem na assembleia litúrgica a possibilidade de acessar o mistério pascal do seu Senhor. Neste sentido, a crítica de Paulo à comunidade que se reúne somente para comer e beber (1Cor 11,17-34) é porque não

\footnotetext{
${ }^{36}$ SCHLIER, H., A eclesiologia do Novo Testamento, p. 139.

${ }^{37}$ BERGER, K., Los primeros cristianos, p.192-196; SCHLIER, H., A eclesiologia do Novo Testamento, p. 143.

${ }^{38}$ DE LUBAC, H., Paradosso e mistero della Chiesa, p. 103-105; SCHLIER, H., A eclesiologia do Novo Testamento, p. 141-143

${ }^{39}$ SCHLIER, H., A eclesiologia do Novo Testamento, p. 140.
} 
compreenderam que a comunidade não é um amontoado de pessoas ruidosas e querelantes, mas que tem um núcleo central: a realidade humana.

Toda vez que a comunidade se reúne em assembleia, esta deve agregar em cada membro o amor, a unidade e a paz. Por isso a celebração acontece no oitavo dia da criação, ou seja, no dia que o Senhor preparou para o ser humano realizar essa conexão fundamental de vida, uns com os outros, e também com seu Senhor, que concede a verdadeira vida no oitavo dia ${ }^{40}$. "A eucaristia é, de fato, por um lado, a ceia, a assembleia de culto, a reunião visível do povo de Deus, uma expressão de sua unidade; e é também, por outro lado, o mistério, a realidade profunda que, dessa unidade, constitui o elo místico, invisível, mas eficaz" ${ }^{41}$.

Portanto, os fiéis que acolhem a Boa Nova anunciada pelos apóstolos, presbíteros, diáconos, e deixam-se lavar nas águas da vida, que os integra ao evento salvífico de Cristo crucificado, como membros do seu corpo, agregam-se como comunidades de fé para celebrarem os mistérios deste Deus, que se presencializa no sacrifício da ceia do Senhor e nos sinais que opera na assembleia pelo Espírito.

\subsection{2.}

\section{Clemente Romano}

A vida de Clemente de Roma é de difícil definição, porém muitos estudiosos $^{42}$ da Igreja nos seus primeiros tempos apresentam algumas soluções para isso. A partir de Irineu de Lião, sabe-se que Clemente é inserido como terceiro sucessor de Pedro na comunidade de Roma, e segundo o Liber Pontificalis "governou a Igreja durante nove anos. Reorganizou a comunidade de Roma, dividindo a cidade em sete setores, recomendando-os a sete diáconos. Fez redigir com cuidado as atas dos mártires" ${ }^{\text {"43 }}$.

A datação da morte de Clemente é conflitante, porém o mais provável é que tenha sido no final do primeiro século cristão, como atesta Eusébio de Cesareia, visto que Clemente afirma na Carta aos Coríntios que demorou para escrever à comunidade de Corinto, pois se abateu sobre a comunidade de Roma uma grande

\footnotetext{
${ }^{40}$ BERGER, K., Los primeros cristianos, p. 141-146.

${ }^{41}$ DE LUBAC, H., Paradosso e mistero della Chiesa, p. 105.

${ }^{42}$ BARDY, G., La Théologie de l'Église, p. 108-109; CALVO, J., Clemente de Roma, p. 20-58; DANIÉLOU, J., La chiesa dei primi tempi, p. 86-88; DROBNER, H., Manual de Patrologia, p. 59; LOPES, G., Patrística pré-nicena, p. 53-56;

${ }^{43}$ LOPES, G., Patrística pré-nicena, p. 52-53.
} 
perseguição, durante o mandato do imperador romano Domiciano (81-96 d.C.). Sendo assim, Clemente deve ter morrido logo após escrever a carta.

A Carta aos Coríntios sempre foi atribuída, pela Tradição, à autoria de Clemente, como cabeça (epíscopo/presbítero) da Igreja de Roma, entre os anos 96 e 98. Contudo, ao invés de continuar pensando que esta obra possa ser de autoria pessoal de Clemente, alguns estudiosos apontam para a autoria da comunidade de Roma em conjunto, pois na própria carta o autor fala de si no plural, mostrando que a comunidade toda é a remetente e que a iniciativa de exortar é conjunta. A carta contém 65 partes, nas quais o autor trata de vários temas, e somente o trecho de 40-58 é dedicado à exortação sobre as notícias de divisão na comunidade de Corinto. Uma perspectiva muito peculiar de Clemente, neste texto, é a utilização dos textos da Septuaginta para citação do AT, uma característica do judeocristianismo em Roma, além das citações do NT terem como fonte a tradição oral $^{44}$.

Contudo, aqui neste estudo a interpretação desta epístola detém-se somente na abordagem que Clemente faz ao referir-se à Igreja como uma agregação de fiéis ou como a possa ter caracterizado, como uma assembleia ou reunião.

O termo ${ }^{45}$ ekklesía aparece três vezes na obra de Clemente (introdução; 44,$3 ; 47,6$ ), porém ele se utiliza de outros termos correlatos para referir-se à Igreja de Deus: rebanho do Senhor, povo eleito, Corpo de Cristo. Mas como um bom conhecedor da Septuaginta, Clemente conhecia o termo ekklesía, que como mostramos anteriormente possui o significado de qahal Yahweh, que ele designa como Israel, e como assembleia de Deus. Sendo assim, não é difícil conceber que o autor compreende a Igreja como este novo Israel, novo povo eleito, depositário das promessas de Deus. Isso aparece expresso na grande oração (59-61), no final da carta: "Que todas as nações reconheçam que tu és o único Deus, que Jesus Cristo é o teu Filho e nós somos o teu povo e ovelhas do teu rebanho"46.

A Igreja de Cristo $^{47}$ é chamada por Ele a reunir-se como um povo, independentemente de onde esteja - "a Igreja de Deus que vive como estrangeira em Roma, para Igreja de Deus que vive como estrangeira em Corinto" ${ }^{48}$-, pois o

\footnotetext{
${ }^{44}$ DANIÉLOU, J., La chiesa dei primi tempi, p. 87-88.

${ }^{45}$ CALVO, J., Clemente de Roma, p. 42-43.

${ }^{46}$ CLEMENTE de Roma, Carta aos coríntios 59,4.

${ }^{47}$ SINISCALCO, P., Il cammino di Cristo nell'Impero romano, p. 113.

${ }^{48}$ CLEMENTE de Roma, Carta aos coríntios, saudação.
} 
importante não é a cidade, local, nível social, mas sim ter ouvido o chamado e respondido a ele com a sua vida. "Portanto, aproximemo-nos dele na santidade de alma, erguendo para Ele mãos puras e sem mancha e amando nosso Pai benévolo e misericordioso, que nos fez participar de sua escolha" ${ }^{49}$. Ainda cita o autor referindo à Igreja: "nós, que por sua vontade fomos chamados em Jesus Cristo, não somos justificados por nós mesmos, nem pela nossa sabedoria, piedade ou inteligência, nem pelas obras que realizamos com pureza de coração, e sim pela fé",50; "essa bem-aventurança é para os que Deus escolheu por meio de Jesus Cristo nosso Senhor" "51; "tu que multiplicas os povos sobre a terra e entre todos escolhestes aqueles que te amam, por meio de Jesus Cristo, teu amadíssimo Filho, mediante o qual nos educaste, santificaste e honraste" ${ }^{\mathrm{P}}$.

O povo chamado por Deus, em Jesus Cristo, responde a este chamado de duas formas, primeiramente reunindo-se em torno do seu Senhor e formando assim comunidades locais para viverem a Boa Nova de Cristo. Como a nova Arca de Noé ${ }^{53}$, a comunidade agrega as diversas realidades da criação, ou seja, os diversos povos, para formar um único povo batizado no Cristo ${ }^{54}$.

Ao responderem a esse chamado e ao se agregarem como Corpo de Cristo ${ }^{55}$, porção santa ${ }^{56}$ e rebanho do Senhor ${ }^{57}$, é preciso que os membros de Cristo se amem como Cristo amou a Igreja. Esta segunda resposta ao chamado é muito significativa em Clemente, pois muitas são as vezes ${ }^{58}$ que na carta ele exorta a comunidade de Corinto, e sua comunidade, ao amor ao outro. Neste sentido, o grande modelo de serviço aos irmãos é o Cristo, "é no amor que o Senhor nos atraiu a si. É por causa de seu amor para conosco, que Jesus Cristo nosso Senhor, conforme a vontade de Deus, deu o seu sangue por nós, sua carne pela nossa carne, e sua vida por nossa vida",59.

\footnotetext{
${ }^{49}$ CLEMENTE de Roma, Carta aos coríntios 29,1.

${ }^{50}$ CLEMENTE de Roma, Carta aos coríntios 32,3.

${ }^{51}$ CLEMENTE de Roma, Carta aos coríntios 50,7.

${ }^{52}$ CLEMENTE de Roma, Carta aos coríntios 59,3.

${ }^{53}$ CLEMENTE de Roma, Carta aos coríntios 9,4.

${ }^{54}$ RAHNER, H., Simboli della chiesa, p. 900.

${ }^{55}$ CLEMENTE de Roma, Carta aos coríntios 37-38.

${ }^{56}$ CLEMENTE de Roma, Carta aos coríntios 30,1.

${ }^{57}$ CLEMENTE de Roma, Carta aos coríntios 44,3; 54,1-2.

${ }^{58}$ CLEMENTE de Roma, Carta aos coríntios 1,2-2,8; 16,1-17; 26,1.

${ }^{59}$ CLEMENTE de Roma, Carta aos coríntios 49,6.
} 
De duas formas a comunidade segue este modelo de Jesus Cristo. A primeira é vivendo na unidade ${ }^{60}$ e sem contendas ${ }^{61}$, exatamente o problema que motivou a carta: "conservemos, portanto, todo o nosso corpo em Cristo Jesus, e cada um seja submisso a seu próximo, conforme o dom que the foi conferido",62 e "unamos, portanto, aos que receberam a graça de Deus; revistamo-nos da concórdia, conservando-nos humildes, castos, longe dos murmuradores e dos maledicentes, justos com obras e não com palavras"63. Assim como foi fundamental para o povo de Israel criar uma unidade ético-moral que constituísse o fundamento último da adesão de cada um dos seus membros a partir das normas extraídas da Torah, também os primeiros cristãos estabeleceram vínculos morais que, muito mais que serem definidos aleatoriamente, serviam para fomentar aquele sentimento de pertença à nova experiência que faziam. A segunda forma é seguindo o exemplo dos que nos antecederam, os mártires, pois "a esses homens, que viveram santamente, ajuntou-se uma imensa multidão de eleitos"64.

Os primeiros modelos para Clemente são os apóstolos Pedro e Paulo ${ }^{65}$, mas a eles outros mártires se somaram, como Danides e Dirces ${ }^{66}$. O martírio é um exemplo de seguimento de Jesus Cristo, mas também em torno destes mártires a Igreja se reúne em assembleia para celebrar suas vidas doadas por Cristo.

Neste primeiro escrito não canônico do cristianismo, a Igreja é apresentada como uma realidade que transcende local e espaço geográfico, porém, ela deve viver a comunhão como princípio. Comunhão no viver, nas dificuldades, nas crises, nos problemas, como membros do Corpo de Cristo. Associados a Ele, pois nele a unidade se torna plena. Assim, descobre-se que quem nos dirige está unido a Cristo $^{67}$. Portanto, a unidade, que é o ser da Igreja, se traduz na vida de cada fiel, e todos numa comunhão de sentimentos e de pensamentos. Os que conduzem são sinal desta unidade ${ }^{68}$ e como apóstolos de Cristo solidificam esta comunhão no

${ }^{60}$ SINISCALCO, P., Il cammino di Cristo nell'Impero romano, p. 122-123.

${ }^{61}$ GROSSI, V.; DI BERARDINO, A., La Chiesa antica, p. 180.

${ }^{62}$ CLEMENTE de Roma, Carta aos coríntios 38,1.

${ }^{63}$ CLEMENTE de Roma, Carta aos coríntios 30,3.

${ }^{64}$ CLEMENTE de Roma, Carta aos coríntios 6,1.

${ }^{65}$ CLEMENTE de Roma, Carta aos coríntios 5,1-7.

${ }^{66}$ CLEMENTE de Roma, Carta aos coríntios 6,2.

${ }^{67}$ GROSSI, V.; DI BERARDINO, A., La Chiesa antica, p. 122-123.

${ }^{68}$ CLEMENTE de Roma, Carta aos coríntios 54. 
que é fundamental, o amor. É neste amor que a Igreja de Cristo encontra a paz, a unidade, a fraternidade e reúne-se como novo Povo de Deus ${ }^{69}$.

\subsection{3.}

\section{Inácio de Antioquia}

As informações ${ }^{70}$ a respeito da vida e obra de Inácio de Antioquia são escassas e diversas. Eusébio de Cesareia ${ }^{71}$ menciona que Inácio foi o segundo sucessor de Pedro na Igreja de Antioquia da Síria, na época do imperador Trajano (98-117). Foi preso e condenado pela sua fé, numa perseguição empreendida por Trajano, e martirizado em Roma, entre 107 e 108.

Neste percurso da Síria a Roma, a Tradição nos transmitiu sete cartas tidas como autênticas, entre outras diversas atribuídas ao autor. Estas sete cartas remetem-se às igrejas por onde Inácio passou ou que o acolheram ${ }^{72}$, além de uma, à comunidade romana, que remeteu antes de sua chegada a Roma e outra, a Policarpo, bispo de Esmirna ${ }^{73}$. Estas cartas não têm intuito teológico doutrinal, pois são cartas pastorais. Porém, elas exortam as comunidades à perseverança e à unidade, exaltam a importância da estrutura hierárquica na constituição da comunidade, previnem contra os erros dos judaizantes ${ }^{74}$, docetas e outros grupos, e convocam à oração comum.

A leitura do epistolário inaciano, a partir da perspectiva eclesiológica, que lhe é muito significativa, possibilita compreender a Igreja em duas dimensões fundamentais: sua unidade como comunidade e aos seus dirigentes, e a eucaristia como constitutiva desta comunidade.

O tema da unidade da Igreja, que tem em Inácio um exímio defensor e divulgador, é fundante para a construção da ekklesía catholiké ${ }^{75}$, ou seja, da Igreja reconhecida em sua universalidade, compreendendo as características e

${ }^{69}$ MAGGIONI, B., La concezione della Chiesa in S. Clemente Romano, p. 3-27; CAELLI, A., La vita comune del clero, p. 33-34.

${ }^{70}$ SIMONETTI, M., Il vangelo e la storia, p. 68-69; CAMELOT, P., Ignace D'Antioche, p. 9-13; LAMELAS, I., As origens do cristianismo, p. 97-109; AYÁN, J., Padres Apostólicos, p. 195-203; DROBNER, H., Manual de patrologia, p. 61-63; MORESCHINI, C.; NORELLI, E., História da literatura cristã antiga grega e latina, p. 162-167.

${ }^{71}$ EUSÉBIO de Cesareia, História eclesiástica, III, 36.

${ }^{72}$ Carta aos efésios; Carta aos magnésios; Carta aos tralianos; Carta aos filadelfienses e Carta ao esmirnotas.

${ }^{73}$ BARDY, G., La théologie de l'Église, p. 102-104.

${ }^{74}$ DANIELOU, J., La chiesa dei primi tempi, p. 72-73.

${ }^{75}$ INÁCIO de Antioquia, Carta aos esmirnotas 8,2; GROSSI, V., Linee di ecclesiologia patrística, p. 69. 
diversidades de cada comunidade local. A Igreja é católica, porque convoca e reúne os fiéis; é verdadeira e autêntica, fiel às origens ${ }^{76}$. Sendo assim, a unidade da Igreja em Inácio de Antioquia é um reflexo do Reino dos céus ${ }^{77}$ :

a partir de cada um, que vos torneis um só coro, a fim de que, na harmonia de vosso acordo, tomando na unidade o tom de Deus, canteis a uma só voz, por meio de Jesus Cristo, um hino ao Pai, para que Ele vos escute e vos reconheça por vossas boas obras, como membros do seu Filho. É proveitoso, portanto, que estejais em unidade inseparável, a fim de sempre participar de Deus ${ }^{78}$.

Nesta perspectiva, a unidade ${ }^{79}$ é construída a partir da concórdia entre os fiéis; não é somente uma unidade espiritual e desvinculada do cotidiano. Cada membro que se agrega à Igreja é de responsabilidade do todo e, pertencendo ao todo, torna-se responsável também. "Todos, individualmente, amai-vos uns aos outros, de coração não dividido" 80 , pois a "vossa fé é o vosso guindaste, a fé é o caminho que eleva até Deus, sois todos companheiros de viagem, portadores de Deus e do templo, portadores de Cristo e do Espírito Santo" ${ }^{\text {81. }}$.

É dessa forma que Inácio afirma por várias vezes que, ao estabelecer contato com um ou outro membro da comunidade, independentemente de se tratar de um ministro ou um leigo, ele viu a todos da comunidade ${ }^{82}$, visto que o amor que une os irmãos e irmãs, não só os une como assembleia dos fiéis, ou para reunião santa, mas a concordância se dá no testemunho da fé, na vivência dos mandamentos e na disposição interior de cada um participar e integrar-se à Igreja. Esta acolhida fraterna conduz ao exercício caritativo, que também é elogiado por Inácio, visto que órfãos, viúvas, entre outros eram acolhidos no seio das famílias e da comunidade como expressão de fé ${ }^{83}$.

A oração comum ${ }^{84}$ possibilita à comunidade conservar a constância entre os irmãos, mas Inácio também agradece e incentiva as orações pelas outras igrejas ${ }^{85}$, o que reforça a integração e construção de um único Corpo de Cristo. "É graças a esse fruto, à sua divina e feliz paixão que nós existimos, a fim de erguer para

\footnotetext{
${ }^{76}$ LAMELAS, I., Sim, cremos, p.271; FUENTE, E., Eclesiología, p. 255.

${ }^{77}$ DROBNER, H., Manual de patrologia, p. 62.

${ }^{78}$ INÁCIO de Antioquia, Carta aos efésios 4,2.

${ }^{79}$ CAMELOT, P., Ignace D’Antioche, p. 36-44; LIÉBAERT, J., Os Padres da Igreja, p. 27

${ }^{80}$ INÁCIO de Antioquia, Carta aos tralianos 13,2.

${ }^{81}$ INÁCIO de Antioquia, Carta aos efésios 9,1-2.

82 INÁCIO de Antioquia, Carta aos efésios 2,1; Carta aos magnésios 6,1; Carta aos romanos, saudação.

${ }^{83}$ INÁCIO de Antioquia, Carta aos esmirnotas 13,1.

${ }^{84}$ INÁCIO de Antioquia, Carta aos tralianos 12,2.

${ }^{85}$ INÁCIO de Antioquia, Carta aos filadelfienses 10,1.
} 
sempre um estandarte pela ressurreição para os seus santos e fiéis, tanto judeus como pagãos, no Corpo único da sua Igreja" ${ }^{\text {" }}$. Esta unidade eclesial tem como modelo a organização e estruturação hierárquica da Trindade, conforme a compreensão inaciana: o bispo, os presbíteros ou colégio de presbíteros, e os diáconos numa subordinação gradual ${ }^{87}$. E a comunidade deve estar unida, submetida, integrada, agregada ao bispo ${ }^{88}$, que é sua cabeça ${ }^{89}$, assim como a Igreja está subordinada a Cristo como seu corpo, e Cristo ao Pai.

A concepção ministerial ${ }^{90}$ nas cartas de Inácio de Antioquia ganha uma característica muito própria, pois não esboça somente os chefes da Igreja e sua estrutura hierarquicamente organizada, mas a ministerialidade é fundamento da unidade eclesial,

assim como o Senhor nada fez, nem por si mesmo nem por meio de seus apóstolos, sem o Pai, com o qual Ele é um, também vós não façais nada sem o bispo e os presbíteros. Não tenteis fazer passar por louvável coisa alguma que fizerdes sozinhos. Pelo contrário, reunidos em comum, haja uma só oração, uma só súplica, um só espírito, uma só esperança no amor, na alegria imaculada, que é Jesus Cristo: nada melhor do que Ele ${ }^{91}$.

Saúdo o bispo digno de Deus, o respeitável presbítero, os meus diáconos, meus companheiros de serviço, e todos individualmente e em comunidade, em nome de Jesus Cristo ${ }^{92}$.

Tal unidade torna-se tão expressa, que os bispos recém-eleitos ${ }^{93}$ para as comunidades são rapidamente integrados na comunidade, que reconhece neles os membros da família não humana, mas espiritual. Alicerçado na compreensão paulina de Igreja, Inácio insiste que os epíscopos tenham destreza nas coisas do Espírito, para bem conduzirem o Corpo de Cristo ${ }^{94}$ em unidade espiritual, nos diversos trabalhos cotidianos e também na doutrina e nos ensinamentos ${ }^{95}$. De modo que "onde estiver o pastor, aí deveis segui-lo como ovelhas"96.

A preocupação de Inácio com as diversas doutrinas que adentram as comunidades é bastante significativa, pois insiste várias vezes na firmeza

${ }^{86}$ INÁCIO de Antioquia, Carta aos esmirnotas 1,2.

${ }^{87}$ GROSSI, V., Linee di ecclesiologia patristica, p. 182; DI BERARDINO, A.; GROSSI, V., La chiesa antica, p. 29.

${ }^{88}$ SCHILLEBEECHX, E., Por uma Igreja mais humana, p. 171.

${ }^{89}$ GROSSI, V.; DI BERARDINO, A., La chiesa antica, p. 100.

${ }^{90}$ GRASSO, D., I carismi nella chiesa antica, p. 681-682; MOTTA, S., Eclesiologia nas cartas de santo Inácio de Antioquia, p. 121-124; DROBNER, H., Manual de patrologia, p. 62.

${ }^{91}$ INÁCIO de Antioquia, Carta aos magnésios 7,1.

92 INÁCIO de Antioquia, Carta aos esmirnotas 12,2.

93 INÁCIO de Antioquia, Carta aos efésios 5,1.

${ }^{94}$ KEHL, M., A Igreja, p. 284.

95 INÁCIO de Antioquia, Carta aos magnésios 6,2; 13,2.

${ }^{96}$ INÁCIO de Antioquia, Carta aos filadelfienses 2,1. 
doutrinal do bispo e como os fiéis precisam caminhar nos bons e corretos ensinamentos. Isso também está presente na carta pessoal que Inácio envia a Policarpo: "Trabalhai uns com os outros e, unidos, combatei, lutai, sofrei, dormi, despertai, como administradores, assessores e servidores de Deus"97. Se o bispo é a cabeça, como Cristo $^{98}$, da Igreja, e deve amá-la e cuidar dela, a comunidade dos fiéis também precisa saber-se submissa ao bispo ${ }^{99}$, pois foi o Espírito de Deus que o designou para tal missão.

É neste vínculo de mútuo amor e conjugação que a comunidade consegue vencer as discórdias e os tormentos ${ }^{100}$, pois Deus não habita onde existe divisão e cólera. Mas Inácio aprofunda a exortação, mostrando que alguns trabalham para desagregarem a vida comunitária e sua fidelidade: "de fato, muitos lobos se fazem dignos de fé, através de aliciamento mau, e cativam os que correm com Deus. Eles, porém, não terão lugar em vossa unidade"101. "Fugi das divisões, como princípio que é de todos os males" 102 .

Sendo assim, Inácio percebe que a comunidade é ameaçada de ambos os lados. Externamente, sofre perseguições e é atormentada - mas aqui há a recomendação ao martírio como testemunho de fé e confiança no Cristo Jesus; mas também sofre por influências internas, que já no início do século II interferem na vivência de fé, nos ensinamentos, na compreensão do Evangelho do Senhor e na missionariedade da comunidade.

Outro ponto que gostaria de destacar na função episcopal, como unidade da Igreja, é a recomendação ${ }^{103}$ que Inácio, bispo de Antioquia, dá a Policarpo, bispo de Esmirna, para que "reúnas uma santa assembleia para eleger alguém que seja estimado por todos e diligente, e se possa nomear 'correio de Deus' para ir à Síria celebrar o vosso ardente amor para glória de Deus" ${ }^{\text {"104 }}$. Ou seja, Inácio incumbe Policarpo de ajudar na reorganização da comunidade que está acéfala, mas para tanto o enviado tem que ter vida de comunidade, bom testemunho e ser pessoa de oração. E ainda, completando a incumbência, solicita a Policarpo a missão de escrever para as outras igrejas que ele não conseguiu em virtude da partida

${ }^{97}$ INÁCIO de Antioquia, Carta à Policarpo 6,1.

${ }^{98}$ GROSSI, V.; DI BERARDINO, A., La chiesa antica, p. 123.

${ }^{99}$ INÁCIO de Antioquia, Carta aos esmirnotas 8,1; Carta aos filadelfienses 7,2.

${ }^{100}$ INÁCIO de Antioquia, Carta aos efésios 8,1; Carta aos filadelfienses 8,1.

${ }^{101}$ INÁCIO de Antioquia, Carta aos filadelfienses 2,2-3,1.

${ }^{102}$ INÁCIO de Antioquia, Carta aos esmirnotas 7,2.

${ }^{103}$ BARDY, G., La théologie de l'Église, p. 104.

${ }^{104}$ INÁCIO de Antioquia, Carta a Policarpo 7,2 
iminente. Tem-se uma referência à importância do episcopado local na Igreja, mas também uma referência à responsabilidade universal (católica) que todo fiel deve ter, principalmente quando designado ao episcopado.

Outra forma de compreender a agregação na obra de Inácio de Antioquia é por meio da compreensão do valor que ele dá à celebração eucarística na vida da comunidade $^{105}$. "Que ninguém se engane: quem não está junto do altar está privado do pão de Deus. Se a oração de duas pessoas juntas tem tal força, quanto mais a do bispo e de toda Igreja! Aquele que não participa da reunião é orgulhoso" $" 106$.

Participar da oração comum é integrar-se à vida da comunidade, pois é neste momento que se pode aprofundar no mistério de Cristo e alimentar-se para a vida em plenitude. Inácio permite compreender que no centro da celebração está o Cristo, Ele é o Pão de Deus. Ajuntar-se a essa assembleia é tornar-se partícipe do Corpo de Cristo, que é a Igreja, bem como unir-se espiritualmente ao Cristo, pão da vida ${ }^{107}$. Aquele que decide ficar fora, não participa do mistério e não se alimenta do Cristo, e também quebra a unidade, pois, como está escrito, "correi todos juntos ao único templo de Deus, ao redor do único altar, em torno do único Jesus Cristo, que saiu do único Pai e que era único em si e para Ele voltou" ${ }^{108}$.

A assembleia convocada e reunida pelo seu Senhor é testemunha contra as outras seitas e grupos que ensinam outras doutrinas e celebram seus mistérios. Por isso, Inácio exorta aos fiéis a tomarem parte no mistério de Cristo e a reconhecerem a celebração eucarística ${ }^{109}$ como este verdadeiro mistério, pois "há uma só carne de nosso Senhor Jesus Cristo, e um só cálice para união do seu corpo, um só santuário, como um só bispo com o presbitério e os diáconos, meus companheiros nos ministérios, para que tudo o que fizerdes o façais segundo Deus" $" 110$.

A vinculação entre a eucaristia, o bispo e a Igreja é o sinal da verdadeira comunidade de fé, pois a celebração eucarística é o centro da vida da comunidade,

\footnotetext{
${ }^{105}$ CAMELOT, P., Ignace D'Antioche, p. 44-47.

${ }^{106}$ INÁCIO de Antioquia, Carta aos efésios 5,2-3.

${ }^{107}$ BERGER, K., Los primeros cristianos, p. 165.

${ }^{108}$ INÁCIO de Antioquia, Carta aos magnésios 7,2.

${ }^{109}$ GROSSI, V.; DI BERARDINO, A., La chiesa antica, p. 131-132.

${ }^{110}$ INÁCIO de Antioquia, Carta aos filadelfienses 4,1.
} 
e o bispo que a preside coloca-se no centro como ministro da unidade, sendo a Igreja o grande mistério que envolve o todo ${ }^{111}$.

\subsection{4. \\ Hermas}

A obra $O$ Pastor (Poimén), de Hermas ${ }^{112}$, foi composta conforme o modelo dos apocalipses judaicos, por volta do século II, em Roma, como atesta o código de Muratori: "Muito recentemente, em nosso tempo, na cidade de Roma, Hermas escreveu $O$ Pastor estando sentado como bispo na cátedra da Igreja de Roma seu irmão Pio" ${ }^{\text {113 }}$. O episcopado de Pio I ocorreu entre 140 e 155. Desta forma, é possível afirmar que o texto é do século II da era cristã. Alguns autores como Irineu de Lião ${ }^{114}$, Tertuliano, Clemente Alexandrino e Orígenes colocaram este apocalipse entre os textos canônicos, porém o código de Muratori permite a leitura somente em reuniões particulares, e não com a assembleia reunida. A estrutura da obra, que pode ter sido escrita em momentos diferentes, é dividida em três partes: cinco visões, doze mandamentos e dez parábolas. O título, O Pastor, surgiu em virtude do anjo da guarda vestido de pastor que dialoga com Hermas, a partir da quinta visão.

A compreensão da eclesiologia presente nos escritos de Hermas embasa-se na terceira visão, na qual a anciã conduz Hermas ao campo e mostra-lhe a edificação de uma grande torre: "Não estás vendo diante de ti uma grande torre que está sendo construída sobre as águas, com pedras quadradas e brilhantes?"115. A construção era conduzida por seis jovens, que vieram com a anciã. Estes encaixavam as pedras trazidas por milhares e milhares de homens, que carregavam-nas do fundo da água e da terra. "Eles colocavam as pedras tiradas do fundo da água, pois já eram lavradas e se ajustavam imediatamente na construção perfeitamente as outras pedras; ajustavam-se tão bem umas com as outras, que não se via nenhuma juntura, e a torre parecia construída como um só bloco"116.

\footnotetext{
${ }^{111}$ FUENTE, E., Eclesiología, p. 198.

112 BARDY, G., La théologie de l'Église, p. 117-119; DROBNER, H., Manual de patrologia, p. 52-54; SINISCALCO, P., Il cammino di Cristo nell'Impero romano, p. 82-83.

${ }^{113}$ STORNIOLO, I; BALANCIN, E., Padres apostólicos, p. 164-165.

${ }^{114}$ IRINEU de Lião, Adversus haereses IV, 20, 2.

115 HERMAS, O Pastor, visões 10,4.

${ }^{116}$ HERMAS, O Pastor, visões 10,6.
} 
Das pedras que vinham da terra, algumas eram utilizadas e outras desprezadas; estas eram quebradas e jogadas longe da torre. Outras pedras estavam ao redor do edifício sem serem utilizadas, pois estavam carcomidas, rachadas e mutiladas. Ainda havia pedras redondas, que não se encaixavam ao edifício. Por fim, algumas pedras foram desprezadas enquanto rolaram para lugares inacessíveis, e outras chegaram até a beirada da água, mas não conseguiram entrar, mesmo sendo seu desejo; por fim outras foram parar no fogo e queimaram-se.

A partir da explicação da visão que Hermas solicita à anciã, fica claro que a Igreja é a torre que se edifica sobre a água, ou seja, a comunidade cristã se constitui com os que foram banhados nas águas da regeneração ${ }^{117}$, o batismo, e encontram em Jesus Cristo o caminho para a vida verdadeira. E a agregação a esta construção não se dá pelo querer de cada um, pois "a torre foi construída pela Palavra do Nome todo-poderoso e glorioso, e é sustentada pela força invisível do Senhor" ${ }^{118}$, mas sim pela decisão pessoal de unir-se aos que responderam ao chamado do Senhor, o que se soma à vontade benevolente de Deus, que nos acolhe e insere nesta construção.

Esta é a imagem dos seis anjos, aos quais Deus confiou a sua criação, e também os outros anjos que carregam as pedras, como afirma o próprio Senhor, falando da ressurreição dos corpos, "com efeito, na ressurreição, nem eles se casam e nem elas se dão em casamento, mas são todos como anjos no céu" (Mt 22,30). Tanto que, com o término da construção, "todos se alegrarão em torno dela" remete-se às núpcias da Igreja-Esposa-Jerusalém celeste com o CristoCordeiro, conforme nos narra João (Ap 21-22) ${ }^{119}$.

A Igreja edifica-se pela agregação de cada uma dessas pedras brancas e quadradas, vindas da terra e da água, que se encaixam perfeitamente à construção, pois "todos esses, caminhando segundo a santidade de Deus, (...) são os que estiveram sempre de mútuo acordo, conservaram a paz entre si e se ouviram reciprocamente" ${ }^{, 120}$. Brancos e límpidos como aqueles que lavaram suas vestes e

\footnotetext{
${ }^{117}$ DANIÉLOU, J., La teologia del giudeo-cristianesimo, p. 403.

${ }^{118}$ HERMAS, O Pastor, visões 11,5.

${ }^{119}$ Paulo também cita esta visão de Igreja em Ef 5,8; PRINZIVALLI, E.; SIMONETTI, M., La teologia degli antichi cristiani, p. 47.

${ }^{120}$ HERMAS, O Pastor, visões 13,1 .
} 
alvejaram-nas no sangue do Cordeiro (Ap 7,9-17), e perseveraram às tribulações confiantes no nome do Deus, no qual renasceram para a vida nova.

Todas as pedras colocadas na construção representam categorias de cristãos dentro da mesma comunidade: as primeiras são os apóstolos, bispos, doutores e diáconos; as do fundo da água são os que passaram por grandes tribulações, os mártires; as que vieram da terra e se encaixam são os que andaram no caminho reto, os cristãos fiéis; as que são colocadas diretamente na construção são os novatos na fé, os neófitos; os que vieram da terra e foram descartados, os penitentes $^{121}$. A fidelidade ao projeto de Deus assumido em Jesus Cristo é o que possibilita a participação nesta assembleia dos fiéis, que agrega neste Povo Santo, que reúne os renascidos para o Pai.

Às outras pedras, que não se agregam ao edifício e são deixadas de fora (os penitentes), falta-lhes a decisão de pertencer e a perseverança no chamado. Por isso, as pedras rejeitadas e jogadas ao redor da torre "são aqueles que pecaram e que desejam fazer penitência"122, são úteis à construção, mas para agregarem-se ao edifício precisam escolher a conversão e penitência, para reconciliação e pertencimento, ou o tempo se finda e ficarão fora do edifício. Fazem parte da assembleia dos fiéis, mas a falta de perseverança no chamado as conduziu ao pecado novamente, e se afastaram do caminho. Há a possibilidade de agregaremse, mas somente pela reconciliação ${ }^{123}$. Desta forma, é possível concluir que a Igreja de Roma acolhia a requisição de muitos pecadores pós-batismais e os organizava para a reconciliação, de modo a regressarem à vida da comunidade. Isso não era universal na Igreja, mas uma prática local e não teorizada neste período $^{124}$.

A anciã continua sua explicação a Hermas ${ }^{125}$, mostrando todos os que ficaram fora do edifício, pois não agregaram-se ao projeto do Senhor. As pedras carcomidas são os que conhecem a verdade e não perseveram, e as pedras com rachaduras são os que carregam rancores mútuos no coração, estão sem paz. As pedras mutiladas, são os que têm fé e estão ligados à justiça, mas ainda vivem iniquidades, e a pedras redondas são as pessoas que mesmo com fé são dominadas

${ }^{121}$ DANIÉLOU, J., La chiesa dei primi tempi, p. 181-182.

122 HERMAS, O Pastor, visões 13,5.

${ }^{123}$ SIMONETTI, M., Il vangelo e la storia, p. 106-107.

${ }^{124}$ SIMONETTI, M., Il vangelo e la storia, p. 119.

${ }^{125}$ HERMAS, O Pastor, visões 14-15. 
pela riqueza, precisam ser aparadas para se tornarem quadradas e se somarem ao edifício.

As pedras jogadas em lugares inacessíveis são os que tiveram fé, mas abandonaram o verdadeiro caminho: "se extraviam e se enveredam

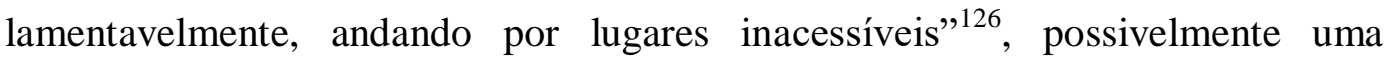
referência aos gnósticos ${ }^{127}$ ou grupos heréticos que querem por outros meios chegar ao conhecimento, e não por meio da palavra da verdade. As pedras que estão no fogo e queimam-se são os que se afastaram de Deus e não querem fazer penitência, já os que caem bem próximo à água são os que querem ser batizados, mas ao conhecerem a verdade, mudam a decisão e retornam aos desejos perversos. Todas estas pedras não se agregam mais à construção, pois tiveram sua possibilidade mas preferiram outros caminhos. Conscientes da verdade, preferem viver na mentira ${ }^{128}$.

Ao finalizar a explicação, a anciã convida Hermas a descobrir outro sinal fundamental para a vida na comunidade cristã. Por ordem do Senhor, sete mulheres sustentam a torre e representam o caminho que todo cristão precisa percorrer na sua vida cristã: fé, continência, simplicidade, ciência, inocência, santidade e caridade. Na visão, isto é chamado de uma filiação, ou seja, a fé vem primeiro, a continência é filha da fé, a simplicidade é filha da continência, a ciência é filha da simplicidade, a inocência é filha da ciência, a santidade é filha da inocência e a caridade é filha de santidade. Todas têm em comum uma única mãe, a Igreja, e "se realizarem todas as obras da mãe, viverás" ${ }^{29}$. Por meio de um caminho feito na Igreja e sob a orientação dela, o fiel vai da fé à caridade e descobre aí o fundamento da vida cristã: a caridade (1Cor 13). A fidelidade e permanência no projeto do Reino de Deus são a perseverança na comunidade dos fiéis.

Em Hermas, a agregação à Igreja é o que possibilita a salvação. A agregação é o farol ${ }^{130}$ que conduz os cristãos à perseverança e estes nela navegam até atingirem a estatura de filhos de Deus, juntando-se a este edifício espiritual que "tem o Filho de Deus como rocha, fundamento: os patriarcas, profetas do Antigo

\footnotetext{
${ }^{126}$ HERMAS, O Pastor, visões $15,1$.

${ }^{127}$ SIMONETTI, M., Il vangelo e la storia, p. 53; LAMELAS, I., As origens do cristianismo, p. 352.

${ }^{128}$ DANIÉLOU, J., La chiesa dei primi tempi, p. 182-183.

${ }^{129}$ HERMAS, O Pastor, visões 16,5.

${ }^{130}$ RAHNER, H., Simboli della chiesa, p. 946.
} 
Testamento, depois os apóstolos, os bispos, doutores e os servidores humildes"131. A comunidade reúne as diversas categorias de fiéis para formar a assembleia do Senhor, na qual não há nem judeus, nem gregos, nem escravos e nem livres, nem homens e nem mulheres, todos em Cristo formam o grande edifício de fé. Enquanto presente no mundo, é uma Igreja em construção que milita no anúncio da Palavra, sendo testemunha e realizando os sinais do seu Senhor, ajuntando às suas fileiras os que o Senhor criou no amor.

\subsection{5.}

\section{Justino de Roma}

Justino $^{132}$, filósofo e mártir, era descendente de uma família greco-pagã de Flavia Neapolis (antiga Siquém), na Palestina. Ele mesmo contou que estudou com mestres estóicos, peripatéticos e pitagóricos, mas foi no médio-platonismo que adentrou mais diretamente ao mundo das ideias de Platão e, assim, assumiu a toga de filósofo, por ter descoberto a verdade. Num encontro com um ancião, filósofo e cristão, em Éfeso, este mostrou-lhe as limitações filosóficas de perscrutar a doutrina das essências e da imortalidade da alma introduzindo-o na vida espiritual cristã e na leitura dos Profetas, pois assim poderia trilhar o caminho para Deus e para Cristo. A partir deste momento, Justino dedica-se à defesa da fé cristã, por diversos lugares até chegar em Roma e fixar-se numa comunidade cristã como leigo e teólogo. Como ele mesmo afirma: "cheguei à conclusão de que somente essa é a filosofia segura e proveitosa"133.

Em Roma, Justino abriu uma escola filosófica cristã, possivelmente a primeira. Além de discípulos, teve também opositores. O filósofo cínico Crescêncio foi o seu principal adversário. Foi denunciado e condenado no tempo de Júnio Rústico, prefeito de Roma, por ser ateu, impiedoso, contra os antigos costumes e as antigas instituições ${ }^{134}$, e foi decapitado junto com seis outros cristãos. A ata do martírio é fidedigna e contemporânea ao ocorrido ${ }^{135}$.

\footnotetext{
${ }^{131}$ STORNIOLO, I; BALANCIN, E., Padres apostólicos, p. 166-167.

${ }^{132}$ SIMONETTI, M., Il vangelo e la storia, p. 78-79; DANIÉLOU, J., La chiesa dei primi tempi, p. 140-145; BARDY, G., La théologie de l'Église, p. 58-61; MORESCHINI, C.; NORELLI, E., História da literatura cristã antiga grega e latina I, p. 277-284.

${ }^{133}$ JUSTINO de Roma, Diálogo com Trifão, n.8.

134 JUSTINO de Roma, Apologia II, 3; Apologia I, 40; GROSSI, V.; DI BERARDINO, A., La chiesa antica, p. 249.

${ }^{135}$ BUENO, D., Actas de los mártires, p. 294-306.
} 
As obras de Justino foram várias ${ }^{136}$, mas chegaram à contemporaneidade três obras: I Apologia, dirigida ao imperador Antonino, o Pio; II Apologia, sem endereçamento, possivelmente uma continuação da I Apologia; Diálogo com Trifão, uma apologia antijudaica, que retrata um diálogo entre Justino e um judeu, Trifão, em Éfeso. Estas três obras têm cunho apologético, no qual o autor busca defender sua visão das coisas contra aqueles que a atacam. Sendo assim, Justino não escreve teologia, mas utiliza-se da compreensão das Sagradas Escrituras e as interpreta com a finalidade de mostrar a beleza da fé cristã e seus fundamentos, tanto contra pagãos, como contra os judeus.

Nos textos apologéticos de Justino, a partir da leitura e interpretação, agora se destacará sua concepção e compreensão da Igreja, especialmente como uma agregação de fiéis.

A primeira compreensão da Igreja como agregação de fiéis surge da forma como Justino valoriza as orações comuns dentro da comunidade. Estas, em primeiro lugar, agregam a comunidade pelo simples fato de rezarem juntos: "em lugar de todas as ofertas, nós o louvamos conforme as nossas forças, com palavras de oração e de ação de graças" ${ }^{\text {"137 }}$. Esta oração não corresponde somente ao fato de elevar a Deus uma prece de súplica e de agradecimento, mas este momento possibilita que a comunidade se una num único Corpo e assim possa ser fortalecida e sustentada como comunhão, "ao mesmo tempo que the suplicamos que nos conceda de novo a incorruptibilidade pela fé que nele temos" ${ }^{\text {"138. }}$.

Em segundo lugar, a oração comum é sinal de fraternidade entre os irmãos presentes e os outros: "nós o levamos aos que se chamam irmãos, no lugar em que estão reunidos, a fim de elevar fervorosamente orações em comum por nós mesmos, por aquele que acaba de ser iluminado e por todos os outros espalhados pelo mundo inteiro"139. A comunidade não se fecha em si mesma, ela compreende a missão que o Cristo lhe deu, de ser sinal para todos de vida e verdade, e ser testemunha de tudo que Cristo anunciou e viveu. Tudo isto conduz à uma nova forma de vida que marca a realidade da comunidade e sua forma de relacionar-se com todos, pois compreendeu de Cristo uma nova proposta de vida:

\footnotetext{
${ }^{136}$ EUSÉBIO de Cesareia, História Eclesiástica, 1-7.

${ }^{137}$ JUSTINO de Roma, Apologia I, 13,1.

138 JUSTINO de Roma, Apologia I, 13,2.

139 JUSTINO de Roma, Apologia I, 65,1.
} 
antes, nós nos odiávamos e nos matávamos mutuamente e não compartilhávamos o lar com aqueles que não pertenciam à nossa raça pela diferença de costumes; agora, depois da aparição de Cristo, vivemos todos juntos, rezamos por nossos inimigos e tratamos de persuadir os que nos aborrecem injustamente, a fim de que, vivendo conforme os belos conselhos de Cristo, tenham boas esperanças de alcançar conosco os mesmos bens que esperamos de Deus, soberano de todas as coisas ${ }^{140}$.

Este testemunho de vida cristã não somente agrega à comunidade os fiéis em Cristo, mas os impulsiona a serem pessoas novas nas diversas realidades de pobreza e sofrimento existentes. Sendo assim, ao defender a nova forma de viver o culto cristão, Justino mostra que o fato de as ofertas não serem queimadas, como nos cultos pagãos e judaicos, significa que elas servem para alimentar os irmãos e a todos que necessitam ${ }^{141}$. E ainda: "os que possuem alguma coisa e queiram, cada um conforme sua livre vontade, dá o que bem lhe parece, e o que foi recolhido se entrega ao presidente. Ele o distribui a órfãos e viúvas" ${ }^{142}$.

A oferta gratuita testemunha favoravelmente à fé cristã, pois manifesta a compreensão do que seu Mestre ensinou e que os fiéis vivem. Dessa forma, Justino mostra que a comunidade se agrega não somente nas orações e nas celebrações, mas também no socorro dos mais necessitados, criando estruturas que possibilitam acolher tais pessoas e os estrangeiros, pois mesmo não sendo cristãos, a acolhida é o primeiro passo da evangelização e do testemunho de Jesus Cristo $^{143}$, diferentemente das obrigações cultuais pagãs que não favorecem a ajuda ao próximo necessitado.

A comunidade que se reúne em assembleia para a oração comum reza o que vive como comunhão fraterna, que os agrega como Corpo de Cristo, que se abre a receber todos e que socorre os que mais precisam. O sinal do ósculo da paz $^{144}$ na reunião da comunidade, por exemplo, marca mais que uma saudação ou sinal de amizade, "é um desejo de unidade, uma oração, um ato de fé na presença de Cristo e na comunhão que Ele constrói, um compromisso de fraternidade" ${ }^{145}$.

\footnotetext{
140 JUSTINO de Roma, Apologia I, 14,3.

${ }^{141}$ JUSTINO de Roma, Apologia I, 13,1; GROSSI, V.; DI BERARDINO, A., La chiesa antica, p. 207.

${ }^{142}$ JUSTINO de Roma, Apologia I, 67,6; GROSSI, V.; DI BERARDINO, A., La chiesa antica, p. 214, 219.

${ }^{143}$ GROSSI, V.; DI BERARDINO, A., La chiesa antica, p. 134.

144 JUSTINO de Roma, Apologia I, 65,2.

145 ALDAZÁBAL, J., Gestos e símbolos, p. 142.
} 
O batismo e a eucaristia ${ }^{146}$ são, também, na obra de Justino, uma forma de compreensão da Igreja como associação de fiéis. Ao batizar, a comunidade não acolhe somente um novo membro, mas também conduz e transmite ao neófito o mesmo banho da regeneração ${ }^{147}$ que a constituiu como irmãos e irmãs na fé em Jesus Cristo. Esta regeneração não brota de uma decisão única, mas sim de um caminho e compreensão da forma de vida da comunidade ${ }^{148}$, que testemunha e agrega este fiel ao seu modo de vida, pois "todos os que se convencem e acreditam que são verdadeiras essas coisas que nós ensinamos e dizemos, são instruídos para que com jejum orem e peçam perdão, e nós oramos e jejuamos juntamente com eles" ${ }^{\prime 149}$.

Há uma decisão livre do que quer conhecer e viver daquela forma, mas também há uma comunidade que acolhe, acompanha, forma, agrega no modo de vida e nas súplicas e preces pelo novo membro. O novo povo de Deus é formado pelos que conhecem este Deus, querem seguir o projeto de Jesus Cristo, aderem a este projeto por livre vontade e não por etnia ou raça, ou somente por contrição como testemunhava João Batista ${ }^{150}$. "Cristo, sendo primogênito de toda a criação, também se tornou princípio de uma nova descendência, regenerada por Ele com a água, a fé e o madeiro" ${ }^{151}$. Assim, o cristão inicia, em sua vida, o cumprimento da salvação como regeneração pela água, na virtude do lenho da cruz de Jesus Cristo $^{152}$.

A Eucaristia na obra de Justino - Diálogo de Trifão [41;70,4] e Apologia I [65-67 $]^{153}$ - é uma agregação de fiéis numa assembleia de ação de graças: "no dia que se chama do sol, celebra-se uma reunião de todos os que moram nas cidades ou nos campos" ${ }^{\prime 154}$. Essa reunião fraterna marca a união dos que professam a mesma confiança na salvação de Cristo, “da qual ninguém pode participar, a não ser que creia serem verdadeiros nossos ensinamentos e se lavou no banho que traz

\footnotetext{
146 GROSSI, V.; DI BERARDINO, A., La chiesa antica, p. 130.

147 JUSTINO de Roma, Apologia I, 61,3.

${ }^{148}$ GROSSI, V.; DI BERARDINO, A., La chiesa antica, p. 59.

149 JUSTINO de Roma, Apologia I, 61,2.

${ }^{150}$ RAHNER, H., Simboli della chiesa, p. 279.

151 JUSTINO de Roma, Diálogo com Trifão 138,2; RAHNER, H., Simboli della chiesa, p. 580-581 e p. 889.

${ }^{152}$ RAHNER, H., Simboli della chiesa, p. 912.

${ }^{153}$ GROSSI, V., Linee di ecclesiologia patrística, p. 149.

154 JUSTINO de Roma, Apologia I, 67,3.
} 
a remissão dos pecados e a regeneração e vive conforme o que Cristo nos ensinou"155.

A constituição da assembleia celebrante ${ }^{156}$ como os que creem no Cristo é espelho da Igreja que reúne em seu seio os crentes no Senhor. Não há construção comunitária sem abertura aos ensinamentos, à fé, aos sinais, à descoberta do mystera $^{157}$ e confiança no Senhor. Além disso, Justino reforça que há um que preside a reunião, o qual recebe as oferendas do pão, vinho e água, mas também faz a "oração eucarística", como uma única prece e não preces individuais. "Esta insistência queria exprimir que a unidade da assembleia reunida pelo Senhor para fazer memória de sua Páscoa, vinha da comunhão na mesma oração ao Pai pelo Filho na unidade do Espírito Santo. A comunhão eclesial é realizada enquanto assembleia que ora unida" ${ }^{\prime 158}$.

Para Justino, o Lógos se torna carne na celebração da eucaristia; também o pão, o vinho e a água se tornam Corpo e Sangue de Cristo ${ }^{159}$; e, para completar uma tríade, a comunidade reunida, que celebra e recebe cada um dos alimentos consagrados pela oração de ação de graças, torna-se, em cada cristão, christóforo $^{160}$.

\subsection{6. \\ Melitão de Sardes}

Melitão ${ }^{161}$ foi bispo da Igreja de Sardes, na Lídia, na segunda metade do século II e é apresentado pela obra de Eusébio de Cesareia ${ }^{162}$ como um fértil autor pela quantidade de obras catalogadas. Como apologeta é reconhecido por ter defendido a fé cristã diante o imperador Marco Aurélio (161-180). Para Melitão, o cristianismo é a "nossa filosofia", como escreveu na Apologia enviada ao imperador, uma compreensão de filosofia bastante comum na época da segunda

\footnotetext{
155 JUSTINO de Roma, Apologia I, 66,1.

${ }^{156}$ GROSSI, V., Linee di ecclesiologia patrística, p. 16.

157 Mistérios da vida de Jesus Cristo: encarnação, nascimento, paixão, morte, ressurreição, ascensão (GROSSI, V.; DI BERARDINO, A., La chiesa antica, p. 256).

${ }^{158}$ SILVA, V., Ecclesia sicuti, p. 246.

159 JUSTINO de Roma, Diálogo com Trifão, 70,4.

${ }^{160}$ SILVA, V., Ecclesia sicuti, p. 246; JUSTINO de Roma, Apologia I, 66; GROSSI, V.; DI BERARDINO, A., La chiesa antica, p. 262.

161 SIMONETTI, M., Il vangelo e la storia, p. 78-80; DROBNER, H., Manual de Patrologia, p. 100-101; MORESCHINI, C.; NORELLI, E., História da literatura cristã antiga grega e latina, p. 199-200; SINISCALCO, P., Il cammino di Cristo nell'Impero romano, p. 46.

${ }^{162}$ História Eclesiástica IV, 26, 1-14.
} 
sofística, pois esta era definida como um conjunto de regras de vida e uma forma de exercício ascético ${ }^{163}$.

No ano de 1940 foi publicada a Homilia sobre a Páscoa, atribuída a Melitão, da qual eram conhecidos somente alguns fragmentos, e o reconhecimento desta homilia possibilitou uma maior consideração ao bispo de Sardes, especialmente pela brilhante retórica presente na prédica. A Homilia sobre a Páscoa é dividida em quatro partes: um prólogo que apresenta a inspiração da homilia no texto de Êxodo 12, para exaltar a antiga e a nova Páscoa [1-10]; uma interpretação da Páscoa do AT [11-45]; uma apresentação do motivo e da preparação do sacrifício pascal de Cristo: o pecado domina a humanidade, tendo como princípio a queda de Adão [46-65]; e finaliza apresentando a nova Páscoa de Cristo, pelo triunfo da ressurreição [66-105]. Nesta última parte, Melitão apresenta uma longa argumentação antijudaica, especialmente centrada na culpa do judeus pelo assassinato de Deus e na sua condenação por não terem percebido o sinal de Deus em Jesus Cristo.

Partindo de uma leitura eclesiológica da Homilia sobre a Páscoa, de Melitão de Sardes, duas interpretações podem ser feitas: a Igreja receptáculo da verdade e a Igreja Corpo de Cristo, resgatada pelo seu corpo e sangue e reunida como membros de Cristo.

Nos parágrafos 39-45, Melitão de Sardes apresenta a primeira e clara definição da Igreja na referida homilia. Todo o trecho remete à relação entre Israel, como prefiguração, e a Igreja, como realização. Sendo assim, o bispo de Sardes afirma que,

a salvação e a verdade do Senhor foram prefiguradas no povo [eleito] e os preceitos do Evangelho foram anunciados pela Lei. O povo [eleito] era, portanto, como o esboço de um plano, e a Lei, uma parábola escrita. Mas o Evangelho é a explicação da Lei, bem como seu cumprimento, e a Igreja é o receptáculo da verdade ${ }^{164}$.

$\mathrm{Na} 1 \mathrm{Tm}$ 3,15, Paulo afirma que "a Igreja do Deus Vivo: coluna e sustentáculo da verdade", numa perspectiva da comunidade cristã como meio para que a Boa Nova seja elevada no maior grau de dignidade. Na citação de Melitão, a Igreja não é somente um tema a ser tratado, mas sim "é dada como contexto, o

${ }^{163}$ PRINZIVALLI, E.; SIMONETTI, M., La teologia degli antichi cristiani, p. 9.
${ }^{164}$ MELITONE di Sardis, Sulla Pasqua 39-40. 
lugar onde a Páscoa é realizada para o povo de Deus que, no Antigo Testamento, tinha seus tipos ou imagens"

Em Melitão, a Igreja predomina como um local ${ }^{166}$ onde todas as figuras e profecias encontram seu cumprimento. É uma definição quase perfeita da Igreja, que é assim apresentada como o verdadeiro povo escolhido. A ideia de receptáculo, para o médio-platonismo no século II, remetia à ideia platônica de mundo sensível, sendo assim, "indicava um espaço vazio, no plano histórico, que vai se enchendo do evangelho de Jesus Cristo"167.

Melitão apresenta o término da comunidade hebraica ${ }^{168}$ com o surgimento do cristianismo, pois o povo eleito agora é a Igreja, fundada na verdade e no evangelho: "mas desde que a Igreja nasceu e o evangelho foi promulgado, a figura foi esvaziada e transmitiu sua eficácia à verdade""169; "o povo [eleito] foi esvaziado [de suas prerrogativas], uma vez que a Igreja foi fundada e a figura foi abolida. O que antes era precioso agora não tem valor, porque o que é verdadeiramente precioso apareceu" ${ }^{170}$.

Naturalmente, essa disposição do assunto, servia para vincular, como tipo e realidade, a Páscoa judaica e a Páscoa cristã. Implicava também uma forte acentuação do tema da rejeição de Israel e da eleição do povo: a substituição definitiva da Lei pelo evangelho, da sinagoga pela Igreja. Além disso, Melitão segue a tradição dos cristãos da Ásia Menor, que interpretam a Igreja como árvore da vida, local no qual Deus plantou nova árvore do paraíso, prefigurada na cruz do Cristo, que dá vida aos que creem. Por isso a Igreja é sinal de união à salvação de Cristo, mas também divisão para os que não compreendem o mistério e ficarão fora da salvação.

$\mathrm{Na}$ segunda compreensão da Igreja Corpo de Cristo, resgatada pelo seu corpo e sangue e reunida como membros de Cristo, é possível compreender que a união do ser humano ao Cristo se dá primeiro na sua integração em corpo e alma. Melitão afirma que o cordeiro de Deus "marcou nossas almas com o selo do seu

\footnotetext{
165 GROSSI, V.; DI BERARDINO, A., La Chiesa antica, p. 31.

${ }^{166}$ CANTALAMESSA, R., Dal kerygma al dogma, p. 250.

${ }^{167}$ GROSSI, V.; DI BERARDINO, A., La Chiesa antica, p. 31-32.

${ }^{168}$ SYKES, A., Melito anti'judaism, p. 272-275; GROSSI, V.; DI BERARDINO, A., La Chiesa antica, p. 32.

${ }^{169}$ MELITONE di Sardis, Sulla Pasqua 42.

${ }^{170}$ MELITONE di Sardis, Sulla Pasqua 43.
} 
Espírito e os membros do nosso corpo com o selo do seu próprio Sangue"171. A alusão clara aos ritos batismais - banho e unção - são as marcas que unem o ser humano a si mesmo, o corpo novo lavado no sangue do cordeiro perdoa os pecados e a alma assinalada com a unção do Espírito concede nova vida. Da escravidão do Egito e do faraó, que oprimiam, são libertados pela graça do Espírito e pelo sangue do cordeiro.

Assim, compreende-se que "foi Ele quem nos fez ir da escravidão à liberdade, das trevas à luz, da morte à vida, da tirania ao Reino eterno, tornandonos um novo sacerdócio, um povo eternamente eleito"172. É no Cristo e no Espírito que este novo povo é eleito definitivamente e constitui a comunidade dos justos, reunidos pelo Senhor como sua grei, para servirem num sacerdócio de vida com o seu Senhor. Purificados e assinalados, retomam a integridade de filhos eleitos e formam assim o Corpo de Cristo, que é a Igreja, a agregação dos que foram salvos, ou melhor, que fizeram a experiência da Páscoa.

Melitão faz a convocação de todos os povos para se aproximarem do Cristo: "venha, então, venha, todas as linhagens humanas, imersas em pecados" ${ }^{173}$, pois a agregação ao Senhor não é mais por raça, como acreditavam os judeus, mas sim pelo reconhecimento do Cristo, como "a páscoa da salvação"174.

O Cordeiro se imolou para que cada um obtenha a sua redenção, a sua vida, a sua luz verdadeira, a sua salvação, a sua ressurreição e o descubra como rei. Nesta compreensão de agregação ao Cristo, a perspectiva possível de se compreender da Homilia de Melitão é que a salvação pascal veio para todos e foi oferecida gratuitamente pelo Filho de Deus, morto e ressuscitado, mas é preciso que se rompa, no ser humano, a barreira que existia entre o ser humano e Deus, e esse novo humano abra-se ao seu Senhor, pois Ele mesmo nos diz: "Eu te levo ao topo dos céus. Eu vou te mostrar o Pai eterno. Eu te levantarei com a minha mão direita" ${ }^{\text {175 }}$. Portanto, Jesus Cristo, a Páscoa da salvação, é o que "conduz ao Pai e é conduzido pelo Pai" ${ }^{176}$.

\footnotetext{
${ }^{171}$ MELITONE di Sardis, Sulla Pasqua 67.

${ }_{172}^{172}$ MELITONE di Sardis, Sulla Pasqua 68.

${ }^{173}$ MELITONE di Sardis, Sulla Pasqua 103.

${ }^{174}$ MELITONE di Sardis, Sulla Pasqua 69; 103.

175 MELITONE di Sardis, Sulla Pasqua 103.

${ }^{176}$ MELITONE di Sardis, Sulla Pasqua 105.
} 


\subsection{7.}

\section{A pedra de Abércio}

Abércio $^{177}$, bispo de Hierápolis, na Frígia oriental, tornou-se célebre nos estudos patrísticos depois da descoberta de um epitáfio, gravado numa lápide mortuária, do qual foram encontrados duas partes pelo arqueólogo W. Ramsay em 1883, na Frígia. Este achado possibilitou uma reconstrução parcial do texto já presente num escrito do século IV, chamado a Vida do bispo Abércio de Hierápolis. No entanto, a inscrição só foi realmente completada com a descoberta do epitáfio de Alexandre, possivelmente gravado em 216, o qual copia o início e o fim do epitáfio de Abércio. Com estas duas fontes, pôde-se reconstruir a lápide toda e ter acesso ao epitáfio completo, gravado sob a presença do próprio bispo, quando tinha 72 anos. Sendo assim, o escrito deve ser anterior ao ano 216 e foi nomeado de a Rainha de todas as inscrições cristãs antigas, pois não há no cristianismo nenhum relato autêntico mais antigo. A peça está guardada no Museu do Vaticano.

O epitáfio tumular é composto de vinte e dois versos hexâmetros gregos e narra brevemente as ações e a vida de Abércio. Um detalhe importante é que a inscrição tumular tem uma linguagem arcana, o que levou à discussão se realmente era um escrito cristão ou um texto sincrético, fruto de uma mistura do cristianismo com o culto à deusa frígia Cibele. A discussão era motivada principalmente pelos avanços teológicos presentes no texto, para uma época tão primitiva. Dentro de todas as discussões, no século $\mathrm{XX}$, o texto foi assumido como cristão, destacando a linguagem do arcano muito comum aos cristãos na Ásia Menor, no século II ${ }^{178}$.

É possível estudar algumas partes da inscrição a partir da compreensão da Igreja como agregação de fiéis. Primeiramente, o autor se identifica como "discípulo de um pastor casto que apascenta seu rebanho de ovelhas por entre montes e planícies, que tem olhos grandes que tudo enxergam"179.

O "casto pastor" é o Cristo, que mesmo morto, ressuscitado e ascendido ao céu, ainda conduz sua grei, seu rebanho, seu povo. E este não somente ajunta o

${ }^{177}$ GUARDUCCI, M., L'iscrizione di Abercio i Roma, p. 174-178; ALTANER, B.; STUIBER, A., Patrologia, p. 106-107; QUASTEN, J., Patrologia I, p. 173-175; MORESCHINI, C.; NORELLI, E., História da literatura cristã antiga grega e latina I, p. 307-308.

${ }_{178}$ GUARDUCCI, M., L'iscrizione di Abercio i Roma, p. 179.

${ }^{179}$ EPÍGRAFE de Abércio 3-5. 
que é seu e cumpre a missão que o Pai lhe deu, mas também o conduz para todos os lados, "montes e planícies". Em todas as realidades, há sempre a presença do pastor, de modo especial, com seu rebanho organizado e reunido. Não deixando de lado a missão de agregar, especialmente as que se perdem e extraviam-se, o que pode ser identificado na epígrafe, pois o "casto pastor... tem olhos grandes que tudo enxergam". Ou seja, olhos que veem a todos e não perdem nenhum dos que o Pai lhe confiou. Além disso, Jesus Cristo transmite aos discípulos-apóstolos a missão de arrebanhar e confirmar os irmãos na fé por todo o mundo.

Num outro trecho, Abércio afirma que o casto pastor o "enviou a Roma para contemplar a soberana majestade e ver a uma rainha de áureas vestes e sandálias de ouro" ${ }^{\prime 180}$. M. Guarducci ${ }^{181}$, para analisar estes versos de Abércio, decidiu aproximá-lo de outro autor, que no mesmo período discutia na sua obra a primazia da Igreja de Roma, Irineu de Lião. Entre as diversas interpretações do porque Irineu coloca a primazia da Igreja de Roma sobre as outras igrejas espalhadas pelo mundo, a autora faz uma análise pertinente, ao afirmar que a universalidade da Igreja de Roma, reconhecida por Irineu, pressupõe a universalidade de Roma, que é o fundamento do Império. E a universalidade de Roma era, naquele tempo, uma certeza indiscutível e incontestável, que todos admitiam e muitos exaltavam. "A capital do Império era considerada o lar de todos os povos, a mãe comum por direito, uma cidade soberana na qual todas as cidades, quase milagrosamente, se condensavam"182.

Desta forma, é possível compreender que, ao ser conduzido até Roma, Abércio faça referência à beleza e à magnanimidade daquela que condensa toda a fé cristã. Por isso, lá está a "rainha de áureas vestes e sandálias de ouro", ou seja, a Esposa de Cristo, resplendente de beleza, "sem mancha nem ruga, ou coisa semelhante, mas santa e irrepreensível" (Ef 5,25-32) - como afirma Paulo. O qual Abércio nomeia como seu companheiro de viagem, ou seja, durante sua peregrinação, o bispo de Hierápolis, lia uma coletânea de cartas paulinas.

Numa proximidade com o Apocalipse de João $(21,2)$, esta rainha é a Jerusalém celeste. Ela marca a visão gloriosa e triunfante de toda a Igreja, que brilha como rainha virtuosa e esplêndida sobre todos, e da qual João afirmará: “eis

\footnotetext{
${ }^{180}$ EPÍGRAFE de Abércio 7-8.

${ }^{181}$ GUARDUCCI, M., L'iscrizione di Abercio i Roma, p. 186-193.

182 GUARDUCCI, M., L'iscrizione di Abercio i Roma, p. 193.
} 
a tenda de Deus com os homens. Ele habitará com eles; eles serão o seu povo e Ele, Deus-com-eles, será o seu Deus” (Ap 21,3-4). É possível compreender aqui não somente o brilho e a grandiosidade da Igreja de Roma, que ainda é perseguida, mas sim a magnitude de toda a Igreja universal, "tenda de Deus com os homens". De Hierápolis a Roma, a Nísibe, à Síria, depois do rio Eufrates, o autor contempla a grandiosidade da fé cristã, da Igreja que se prepara como uma rainha, uma noiva, uma Esposa para o seu Senhor.

Abércio afirma: "lá vi um povo que tinha um selo (sigilo ${ }^{183}$ ) resplandecente"184. À primeira vista, parece que o bispo-peregrino avistou algumas pessoas ou um grupo específico marcado com o selo batismal, mas, além disso, ele vê um povo que resplandece de beleza, por trazer a marca do Senhor. É este selo que marca e identifica os que reconheceram Jesus Cristo e assumiram o seu projeto de vida e salvação marcados pelo batismo. Formam a comunidade dos que o Senhor separou para si, daqueles que serão salvos. São os marcados com o selo do Cordeiro (Ap 7,4-8): “depois disso, eis que vi uma grande multidão, que ninguém podia contar, de todas as nações, tribos, povos e línguas. Estavam de pé diante do trono e diante do Cordeiro, trajados com vestes brancas e com palmas na mão" (Ap 7,9). Este povo visto por Abércio, é o povo que se deixou marcar pelo cordeiro e o segue no caminho da vida.

O bispo-peregrino encontra irmãos em todas as partes e experimenta a fraternidade que os une: "em todas as partes encontrei irmãos", "em todas as partes me guiava a fé", "e em todas as partes me serviam comida""185. A esta comunidade de fé agrega-se pela Palavra do seu Senhor, neste caso transmitida pelo próprio Senhor e pelos escritos de Paulo, mas também pela vivência da Palavra. O Senhor ressuscitado é sinal de vida e salvação. Assim, a comunidade deve ser viva para todos, acolhendo-os como irmãos, conduzindo-os pela fé em Jesus Cristo, e alimentando os corpos para nutrir o espírito.

Neste ponto, a epígrafe de Abércio apresenta um texto valioso: "em todas as partes me guiava a fé e em todas as partes me serviam [como] comida o peixe do manancial, muito grande, puro, que foi pescado por uma virgem casta, e o dava sempre a comer aos amigos, tinham um vinho delicioso e serviam misturado

${ }^{183}$ BAZÁN, F., El símbolo Cristiano del pez origen y proyecciones, p. 145; GUARDUCCI, M., L'iscrizione di Abercio i Roma, p. 186.

${ }^{184}$ EPÍGRAFE de Abércio 9.

${ }^{185}$ EPÍGRAFE de Abércio 11-13. 
vinho e pão com água" ${ }^{186}$. A comunidade reunida para o ágape é sinal da memória pascal $^{187}$ do cordeiro, ou seja, uma comunidade que se agrega em torno da eucaristia, como mistério fontal e fundamental para existência e vivência da comunidade.

Por isso Abércio aponta que, por onde passa, recebe o alimento "que foi pescado por uma virgem casta", ou seja, a memória da Encarnação do Verbo de Deus, pela graça do Espírito que habitou no seio da Virgem Maria e trouxe ao mundo o verdadeiro alimento, o peixe ${ }^{188}$ : Jesus, Cristo, de Deus, Filho, Salvador. E sobre o "vinho delicioso" que é servido com o pão e água pode-se fazer uma analogia com as bodas de Caná (Jo 2), onde a alegria retorna quando é servido o vinho verdadeiro, o melhor. $\mathrm{O}$ vinho delicioso, o pão da vida e a fonte de vida eterna são os sinais que reúnem a comunidade como uma agregação de fiéis em torno do seu Senhor e Deus.

\subsection{8.}

\section{Grupos gnósticos}

A agregação a um grupo gnóstico nasce de uma experiência existencial, pois a pessoa sente a necessidade de libertar-se da prisão do mundo, das suas adversidades, sente-se um estrangeiro, um exilado, um peregrino neste mundo. Dessa forma a criação como obra de Deus é negada totalmente, a matéria é ruim. Esta experiência, que se pode classificar como existencialista, obriga o gnóstico a saber, a despertar, a tomar consciência de não ser pertencente a este mundo, mas sim a um mundo espiritual para o qual necessita retornar. "Ser gnóstico é haver recuperado a memória perdida, e ter uma alegria do encontro com o próprio eu"189.

Os gnósticos assumem ter uma revelação de nível superior e mais profunda que a massa de batizados e ignorantes cristãos, mas esta Revelação se dá no seio da Igreja oficial. Não se preocupam com ritos externos, pois é necessário que internamente a pessoa descubra a gnose e assim vá crescendo no verdadeiro conhecimento da Escritura, descobrindo as revelações ali presentes. E a cerimônia

\footnotetext{
${ }^{186}$ EPÍGRAFE de Abércio 13-16.

${ }^{187}$ BARDY, G., La théologie de l'Église, p. 94-95; GUARDUCCI, M., L’iscrizione di Abercio i Roma, p. 198-203.

188 SIMONETTI, M., Il Vangelo e la storia, p. 184.

${ }^{189}$ POSE, E., Pensamiento teológico de san Ireneo de Lión, p. 592.
} 
batismal ${ }^{190}$, nos grupos gnósticos, estava intimamente associada à recepção desta gnose, que o capacitava a vencer a morte.

Sendo assim, a igreja gnóstica, ou o grupo gnóstico, nos primeiros três séculos do cristianismo, tem duas características interessantes que o define: surge dentro das comunidades cristãs e tem o rito batismal gnóstico. Dentro da comunidade cristã, os gnósticos concebiam-se como os pertencentes ao cristianismo mais autêntico e se sentiam como a elite intelectual cristã, pois tinham a capacidade de decifrar a linguagem simbólica dos textos bíblicos, além de compreenderem o que seus autores quiseram realmente expressar. Isso criava no seio da comunidade cristã uma divisão entre os mais simples intelectualmente e os que se utilizavam dos conhecimentos obtidos exteriormente para diferenciarem-se dos outros ${ }^{191}$. Desse modo, é possível afirmar que, mesmo não tendo uma definição clara do que era a igreja gnóstica, essa forma de sentir-se diferenciado dos outros já possibilitava alguns membros a agregarem-se por afinidade às teorias gnósticas.

Outra carcterística é o ritual batismal gnóstico, visto que para pertencer ao grupo gnóstico a pessoa não necessitava de ser um descendente legítimo de Set terceiro filho de Adão e Eva, considerado o pai de todos os gnósticos - para ser um dos eleitos, um dos iluminados, pois "o batismo gnóstico marcava um passo decisivo na vida espiritual do gnóstico, envolvendo a renúncia, instrução, aprendizagem e iniciação a um novo parentesco e a um novo estado de vida"192 ${ }^{\text {. E }}$ com este rito batismal era plantada na pessoa a semente de Set, o que possibilitava o acesso à contemplação do divino ${ }^{193}$.

Não é possível ter a clareza se o rito expresso nos textos era realmente realizado ou, então, se essas referências ao batismo não passavam de meras metáforas, uma descrição mística da salvação pelo conhecimento (expressão presente no final do Apocalipse de Adão). Contudo, ficam algumas interrogações, pois, se havia também um rito gnóstico físico do batismo, este era uma iniciação singular à igreja gnóstica, ou era um ato de iluminação mística, passível de repetição? Qual era a relação entre esse rito e o batismo recebido pelos membros

\footnotetext{
${ }^{190}$ LAYTON, B., As escrituras gnósticas, p. 19-20.

${ }^{191}$ FIEDROWICZ, M., Teologia dei padri della chiesa, p. 13-16.

192 LAYTON, B., As escrituras gnósticas, p. 19.

${ }^{193}$ BRAKKE, D., Los gnóstikos, p. 121-122.
} 
da comunidade cristã não gnóstica, que, depois, se converteram ao cristianismo gnóstico? O silêncio é a única resposta dada pelas Escrituras ${ }^{194}$.

A igreja gnóstica, de forma geral, por mais que as diferenças entre os grupos sejam diversas, organizava-se a partir das comunidades cristãs, como membros de um nível elevado de conhecimento e possibilidade de interpretação dos mistérios. Agregavam aos grupos dos seletos em virtude da gnose que era adquirida, ou conscientizavam-se de tê-la em seu interior a partir do batismo gnóstico, que selava o eleito. E nas assembleias reuniam-se, de forma restrita, para celebrar os mistérios próprios de cada grupo e em cada região.

V. Grossi, ao caracterizar a Igreja cristã pré-nicena, inicialmente a diferencia, em relação ao espaço, do ambiente já existente entre os grupos judaicos. Todavia, isso não impede que sua organização parta da perspectiva de outros grupos religiosos da época, visto que os cristãos procuram mais que um local físico. Eles seguem a proposta de Jesus à samaritana: os verdadeiros adoradores adorarão ao Pai em Espírito e verdade.

Uma primeira característica dessa comunidade nascente é a dialética heresia-ortodoxia $^{195}$, ou seja, dentro da comunidade cristã, que se estabelece em diversos lugares e diversas culturas, a compreensão da proposta de Jesus de Nazaré ganha interpretações diversas. Por isso, não cabe mais a compreensão de cristianismo, mas a de cristianismos.

Mesmo assim, é preciso ter clareza de que o fato Jesus Cristo, sua vida e anúncio, tem um período claro na história, com local e data. Sendo assim, é preciso que quem se diga seguidor dele o faça a partir da sua proposta. Logo, V. Grossi opõe-se à construção de que a heresia só surge porque foi definida uma ortodoxia. Em lugar disso, retoma a lógica correta: o projeto de Jesus Cristo veio dos apóstolos para a Igreja, e foi dessa expansão eclesial que nasceram interpretações diversas e discrepantes.

Além disso, não foi somente a difusão do cristianismo pelo mundo helenizado que fez surgir uma diferenciação, dentro da Igreja, entre grupo institucional e grupo carismático. A filosofia helenista influenciou em muito os primeiros pensadores cristãos. Porém, não se pode perder de vista o ponto de onde partiram para construírem os símbolos, a regula fidei, que foi o cânone bíblico. O

${ }^{194}$ LAYTON, B., As escrituras gnósticas, p. 20; BRAKKE, D., Los gnósticos, p. 121-125.

195 GROSSI, V., Linee di ecclesiologia patrística, p. 10-14. 
método de interpretação pode ter sido diverso, mas o que fundamentou a compreensão da Boa Nova de Jesus Cristo foi a própria Palavra de Deus. Sendo assim, o helenismo influenciou, mas não delimitou; ofereceu método e possibilitou o aprofundamento das verdades ensinadas e vividas por Cristo e seus apóstolos.

A segunda característica das primeiras comunidades, apresentada por V. Grossi, é o cânone da Sagrada Escritura ${ }^{196}$. A comunidade cristã levou estes textos sagrados para dentro dos seus cultos e passou a utilizá-los, tanto os escritos como os orais, para marcar a reunião litúrgica da comunidade.

Nessas liturgias, a Palavra era o meio que os cristãos tinham de se aproximarem dos mistérios de Jesus Cristo. Esta era uma Palavra qualificada e aceita por toda a comunidade, e o que se manifestava nas assembleias litúrgicas servia de referência para a vida contidiana.

A comunidade dos crentes se sentia agregada mesmo quando não reunida no mesmo ambiente. "Tais assembleias, mais que qualquer outra reunião, exprimiam o sentir, o crer e o agir dos cristãos"197. V. Grossi afirma que Paulo utiliza o vocábulo kanôn para identificar um comportamento cristão exemplar dentro das comunidades, mostrando assim como a Palavra estava presente na vida e a vivência de fé era celebrada na reunião da comunidade. Vale destacar, ainda, que a denominação dessa Escritura como apostólica possibilitava às diversas agregações saberem separar o que era o fundamento da fé do que eram outros textos diversos, não somente os heréticos.

\section{2. \\ Fontes bíblicas}

\subsection{1.}

\section{As Sagradas Escrituras na obra de Irineu de Lião}

No segundo século da era cristã, período no qual Irineu de Lião escreveu sua obra, não é possível afirmar a existência de um códice escriturístico, ou uma Bíblia, como hoje se conhece. Mas nem por isso a Sagrada Escritura deixou de ser citada e comentada por vários escritores e também pelo bispo de Lião, pois em toda sua obra afirma que por meio das Escrituras apresentará sua argumentação. É

\footnotetext{
${ }^{196}$ GROSSI, V., Linee di ecclesiologia patrística, p. 14-17.

${ }^{197}$ GROSSI, V., Linee di ecclesiologia patrística, p. 15.
} 
certo que, para as citações do Antigo Testamento, Irineu utilizou a edição grega do Setenta, já que era o texto em uso pelas comunidades judaicas na diáspora e, a partir delas, os cristãos tiveram acesso ao texto. Porém, os textos do Novo Testamento estavam editados separadamente em conjuntos próprios segundo os autores ou uso nas igrejas. Sendo assim, não havia um conjunto único, como os códices Sinaítico e Vaticano, existentes a partir do século IV ${ }^{198}$.

Nas suas obras, Epideixis e Adversus haereses, Irineu demonstra que, mesmo não tendo um volume único das Escrituras, tinha acesso à quase sua totalidade. Decerto, é impressionante o conhecimento escriturístico de Irineu, pois citou praticamente todos os livros bíblicos, com exceção apenas dos textos de Ester, Crônicas, Eclesiastes, Cântico dos cânticos, Jó, Abdias e Macabeus do Antigo Testamento, e carta a Filemon e II carta de João do Novo Testamento ${ }^{199}$. Outra constatação a acrescentar é a quantidade de citações que Irineu utilizou nas suas obras. Por exemplo, nos cinco volumes da Adversus haereses, editada pela Source chrétiennes, é possível contabilizar 1800 citações do Novo Testamento, das quais 950 são citações diretas, e 820 referências ao Antigo Testamento, de cujas 450 são citações diretas ${ }^{200}$. Portanto, a partir do exemplo de Irineu e da Igreja de Lião, é possível defender a tese da presença dos textos escriturísticos no século II e a sua importância nas Igrejas dos primeiros séculos.

Contudo, a preocupação de Irineu de Lião não está voltada para a materialidade do cânon escriturístico nas comunidades, nem para a divisão deste em dois testamentos ${ }^{201}$, nem para a edição completa de um códice, mas sim para o combate aos grupos gnósticos e a Marcião, num plano ${ }^{202}$, e em outra perspectiva, resolver a polêmica com os judaizantes que insistiam na não continuidade da Revelação de Jesus, ou seja, não aceitavam a continuidade da história da salvação iniciada em Abraão e levada a cabo na encarnação do Verbo de Deus.

Por conseguinte, ao utilizar o termo Escritura, Irineu designa o conjunto dos textos sagrados numa continuidade sem interrupção entre o Antigo e o Novo Testamento. A dualidade das Escrituras corresponde a uma unidade profunda na

\footnotetext{
198 BARBAGLIA, S., Irineo di Lione e la comunicazione della fede cristiana, p. 110-113.

${ }^{199}$ RIBEIRO, H., Contra as heresias, p. 16.

${ }^{200}$ BARBAGLIA, S., Irineo di Lione e la comunicazione della fede cristiana, p. 115; BENOIT, A., Saint Irénée, p. 74-75.

${ }^{201}$ IRINEU de Lião, Adversus haereses IV, 32, 1-2.

${ }^{202}$ IRINEU de Lião, Adversus haereses IV, 34, 1.
} 
mensagem, mostrando que ambas as partes derivam de único e mesmo Deus ${ }^{203}$. E isso se torna mais claro, pois Irineu foi o primeiro autor cristão que utilizou o Novo Testamento, igualando-o em autoridade e validade com o Antigo ${ }^{204}$. Por vezes, Irineu também mostra a continuidade da Escritura, apresentando duas citações, uma do Antigo, outra do Novo Testamento, para justificar a mesma tese:

nós, porém, nos conservamos firmes na regra da verdade, isto é, que existe um só Deus onipotente que tudo criou pelo seu Verbo, plasmou e fez que o que não existia passasse a existir, como diz a Escritura: 'pela Palavra do Senhor os céus foram feitos e pelo sopro de sua boca toda a potência deles' (S1 33,6). E ainda: 'tudo foi feito por meio dele e sem Ele nada foi feito' $(\text { Jo } 1,3)^{205}$.

Em Irineu de Lião, as Sagradas Escrituras nascem na esteira da tradição, pois os apóstolos anunciaram o que Jesus Cristo fez e ensinou. A partir daí, a pregação passou pelo processo de consignação escrita:

não foi, portanto, por ninguém mais que tivemos conhecimento da economia da nossa salvação, mas somente por aqueles pelos quais nos chegou o Evangelho, que eles primeiro pregaram e, depois, pela vontade de Deus, transmitiram nas Escrituras, para que fosse para nós fundamento e coluna da nossa fé. ${ }^{206}$

O fato de os apóstolos não terem escrito as Escrituras não diminui a sua importância; ao contrário, fortalece-a e testemunha favoravelmente a seu respeito, pois muitos povos sem escrita nem papel creram no anúncio apostólico e guardaram essa verdade gravada no coração. "Assim, graças à antiga tradição dos apóstolos, não admitem absolutamente se possa pensar em nenhuma das invenções mentirosas dos hereges" ${ }^{207}$. Portanto, a verdade comunicada pelos apóstolos garante a veracidade e força da Palavra, pois ela foi comunicada e inspirada pelo Espírito Santo, não suportando nenhuma invenção ou falsidade, nem acréscimo ou interpretação errôena.

A Tradição apostólica ${ }^{208}$, definida pela primeira vez por Irineu, designa o ensinamento da Igreja realizado pelos presbíteros e sucessores dos apóstolos, o qual é colocado na esteira de continuidade com o que o Antigo Testamento registrou dos profetas e patriarcas. Ou, ainda, num caminho de continuidade, em tempos diferentes e localidades distantes, ambos anunciaram o projeto de Deus,

\footnotetext{
${ }^{203}$ IRINEU de Lião, Adversus haereses III, 32, 1.

${ }^{204}$ FANTINO, J., La théologie d'Irénée, p. 29-30; SIMONETTI, M., Lettera e/o allegoria, p. 43; IRINEU de Lião, Adversus haereses II, 28, 3; III, 12, 11.

${ }^{205}$ IRINEU de Lião, Adversus haereses I, 22, 1.

${ }^{206}$ IRINEU de Lião, Adversus haereses III, 1, 1.

${ }^{207}$ IRINEU de Lião, Adversus haereses III, 4, 2.

${ }^{208}$ IRINEU de Lião, Adversus haereses III, 2, 2.
} 
concretizado no Verbo, Filho de Deus. Este ensinamento da Igreja, guiada e conduzida pelo Espírito Santo, faz a fé ser proclamada e o dom de Deus confirma este ensinamento.

A partir da pregação, estas verdades de fé passaram a fazer parte de um conjunto de textos e escritos que as igrejas consagravam como inspirados por Deus. Muitos deles eram utilizados na liturgia local ou pertenciam a epíscopos e presbíteros destas igrejas. Passavam assim a serem lidos e ensinados, reinterpretados e ganhavam uma consideração por parte da comunidade cristã, o que os conduzia a formar um dos exemplares sagrados.

Neste ínterim, para Irineu, os textos são conhecidos como testamentos, ou seja, remetiam aos ensinamentos passados, deixados pelos apóstolos e seguidores de Jesus Cristo, que transmitiram as verdades recolhidas em seus corações e, conduzidos pelo Espírito, as ensinaram a todos.

Estas "verdades", Irineu reconheceu como regula fidei ou regula veritatis. Esta era compreendida de duas formas, primeiramente as verdades de fé, tanto para serem proclamadas no momento batismal, como também utilizadas para a formação dos catecúmenos e para a instrução da Igreja de Lião. Num segundo momento, a regula fidei foi utilizada como parâmetro para apresentar a verdadeira fé, com base na tradição dos apóstolos, diante das teorias ocultas dos grupos gnósticos e de suas falsas afirmações ${ }^{209}$.

Para Irineu, a exegese da Igreja deve estar em acordo com a compreensão que a Tradição tem das Escrituras (regula fidei). A interpretação não pode se basear somente em critérios racionais, mas tem que levar em conta a doutrina e a autoridade da Tradição, que a Igreja transmite desde os tempos apostólicos ${ }^{210}$.

Contudo, os gnósticos interpretavam as Escrituras com base na exegese alegórica, a qual tinha como principal expoente no século I o filósofo Fílon de Alexandria que, com seus métodos filosóficos, influenciou todos os interessados em compreender as Escrituras, tanto judeus, pagãos e gnósticos como cristãos. Os seus comentários dos textos veterotestamentários, principalmente o Pentateuco, eram uma expressão do humanismo religioso elevado a uma mística especulativa.

\footnotetext{
209 RÄISÄNEN, H., El nacimento de lãs creencias cristianas, p. 468-469; IRINEU de Lião, Adversus haereses I, 8, 1.

${ }^{210}$ BARRERA, J., La Biblia judía y la Biblia Cristiana, p. 590.
} 
Fílon deu pouca relevância à perspectiva histórica de Israel, do Povo de Deus e também do messianismo do judaísmo bíblico ${ }^{211}$.

A hermenêutica alegórica não surgiu com Fílon, mas este deu a ela características próprias, pois, por ser um médio-platônico, formado na dialética e no dualismo filosófico, trouxe para a exegese todo esse arcabouço instrumental e metodológico, para realizar uma hermenêutica filosófico-religiosa dos textos do Antigo Testamento. Mesmo assim, não abandonou a tradição judaica; por isso os conceitos judaicos das Escrituras ganhavam uma definição filosófica ${ }^{212}$. "No âmbito da exegese alegórica, o elemento mítico é posto de lado e aflora, pelo contrário, em toda clareza o verdadeiro significado" ${ }^{\text {213 }}$, pois a Escritura sendo guardiã da verdade, segundo Fílon, não podia apresentar inexatidões, ficções e redundâncias.

Assim, era preciso superar o imediatismo interpretativo que apresentava dificuldades e buscar o sentido mais profundo, "pensar que nenhuma das afirmações feitas deve ser entendida ao pé da letra, e que se deva pelo contrário tomar o caminho da alegoria, estimada pelos filósofos, e começar nosso discurso deste ponto de vista" ${ }^{214}$. Como as palavras pronunciadas contêm significados simbólicos referidos a conceitos que podem ser captados somente com a inteligência, então, para Fílon, a leitura filosófica era uma chave hermenêutica imprescindível para a leitura e compreensão das Escrituras.

No entanto, o bispo de Lião criticou a exegese alegórica dos textos bíblicos, utilizada pelos gnósticos, pois não respeitava, nas suas interpretações, nem a estrutura do texto, nem a mensagem transmitida e muito menos o local onde o texto fora elaborado. Mas sim utilizavam as diversas perícopes para provar suas teses e defender suas posições, ou melhor, para dar um fundamento escriturístico às suas doutrinas. "É clara a arbitrariedade da exegese deles; falsificam o texto com exegese capciosa, torcendo toda Palavra da Escritura"215.

Além disso, Irineu afirmou que as teses dos gnósticos eram fruto da manipulação dos textos escriturísticos conforme seus interesses, pois a essência das suas hipóteses "nem os profetas enunciaram, nem o Senhor ensinou, nem os

${ }^{211}$ BARRERA, J., La Biblia judía y la Biblia Cristiana, p. 521-523; CALABI, F., Fílon de Alexandria, p. 35-40.

${ }^{212}$ BARRERA, J., La Biblia judía y la Biblia Cristiana, p. 521-523.

${ }^{213}$ CALABI, F., Fílon de Alexandria, p. 37.

${ }^{214}$ CALABI, F., Fílon de Alexandria, p. 37.

${ }^{215}$ IRINEU de Lião, Adversus haereses I, 9, 2. 
apóstolos nos passaram; lendo o que não fora escrito, ajuntam às parábolas do Senhor, palavras proféticas, ou ensinos apostólicos, de forma que a composição não pareça ser contestável"216.

Ao divergir da exegese alegórica dos gnósticos, Irineu apresentou um novo método hermenêutico de leitura das Escrituras, a regula fidei. A regra de fé, segundo Irineu, norteava e unia toda a Igreja: "no entanto, toda a Igreja mantém uma única e a mesma fé em todo o mundo" ${ }^{217}$. Ou seja, a base que alicerçava a Igreja era sólida e não volátil e misturada como as doutrinas e exegeses gnósticas. Ademais, ele visou mostrar que o desenvolvimento intelectivo desta doutrina não a diminuiu nem aumentou, "a exposição feita com sabedoria maior ou menor, não quer dizer que se muda a doutrina ou que se pense noutro Deus além daquele que é o Criador" ${ }^{218}$.

Além disso, Irineu utiliza, nas suas obras, outro método exegético que encontra nas pessoas ou acontecimentos do Antigo Testamento typos ${ }^{219}$ ou figuras que se realizaram no Novo Testamento ou escatologicamente. "Trata-se de uma tipologia histórica que entende a continuidade de ambos os testamentos como uma linha horizontal de progresso e culminação histórica"220.

Irineu afirma que os profetas não viram Deus face a face, mas somente as verdades reveladas pelo Verbo de Deus para serem transmitidas aos homens. Dessa forma, desde Adão, o Verbo de Deus é quem estabelece a relação com os seres humanos na história e é nessa perspectiva que é possível interpretar o Novo Testamento com os tipos do Antigo Testamento. "De fato, em todas as Escrituras está semeado o Filho de Deus que ora fala com Abraão, ora com Noé, dando-lhe as medidas da arca, ora procura Adão, ora faz vir o juízo sobre os sodomitas, ora aparece e guia Jacó no caminho e da sarça fala a Moisés"221.

Essa dimensão intertextual, na obra de Irineu, documenta o uso amplo da tipologia, sendo assim, a dinâmica promessa-cumprimento permite que Irineu percorra toda a Escritura, tendo o evento cristológico como centro fundamental e farol a iluminar toda hermenêutica cristã. Jesus Cristo, a Palavra de Deus, é o mestre de todo discípulo que quer aprender a compreender as Escrituras, pois Ele

\footnotetext{
${ }^{216}$ IRINEU de Lião, Adversus haereses I, 8, 1.

${ }^{217}$ IRINEU de Lião, Adversus haereses I, 10, 3.

${ }^{218}$ IRINEU de Lião, Adversus haereses I, 10, 3.

${ }^{219}$ SIMONETTI, M., Lettera e/o allegoria, p. 40.

${ }^{220}$ TREVIJANO, R., A Bíblia no cristianismo antigo, p. 79.

${ }^{221}$ IRINEU de Lião, Adversus haereses IV, 10, 1.
} 
é o autêntico intérprete do Pai. E os quatro Evangelhos são a fonte hermenêutica do Mestre Jesus, pois eles são os responsáveis por revelarem e confirmarem a face do único Deus Pai, que envia o Espírito Santo, o qual guiou os profetas e agora reina na Igreja de Deus. Contudo, “o sentido pleno das Escrituras permanece oculto para aqueles que não aceitam este processo, que, como veremos, confirma para ajudar a compreender melhor a 'regra da verdade",222.

Opondo-se aos grupos gnósticos que retiravam o texto bíblico do contexto e, assim, extrapolavam sua interpretação da forma que necessitavam, Irineu mostra que a verdadeira interpretação é aquela que considera a globalidade das Escrituras $^{223}$, pois onde uma passagem é obscura, outra é evidente e clara; onde há textos ambíguos e incertos, outros são precisos e diretos. Desta forma, o bispo de Lião salva a harmonia do texto e de Deus, que é o mesmo em ambos os testamentos ${ }^{224}$. Sendo assim, "conservaremos a nossa fé, estaremos longe dos perigos e concordes com toda a Escritura que Deus nos deu; e, na polifonia dos textos, escutaremos em nós uma só melodia harmoniosa a cantar o Deus que fez todas as coisas" 225 .

Portanto, em Irineu, a hermenêutica dos textos escriturísticos parte de um princípio universal e fundante: a Tradição ${ }^{226}$. Esta, segundo o autor, são os textos escriturísticos, os escritos apostólicos, mas, de modo essencial, o ensinamento oral transmitido nas comunidades cristãs pelos epíscopos na sua missão de ensinar, pregar e testemunhar a fé que receberam dos antecessores. Esta regula fidei são os cânones da verdade, a síntese da doutrina que fora difundida por Jesus aos seus apóstolos e transmitida pelos seus sucessores. E este é o principal instrumento para combater os grupos gnósticos: "quem possui a regra da verdade aprendida no batismo reconhecerá os nomes, as expressões, as parábolas que são das Escrituras (...). Recolocando cada uma das palavras no seu lugar, ajustadas ao corpo da verdade, desvendará e mostrará a inconsistência das suas fantasias"227.

A. Orbe ${ }^{228}$, ao tratar da exegese irineana em oposição aos gnósticos, afirma que estes justificam que a compreensão sublime dos textos e parábolas se encontra

\footnotetext{
${ }^{222}$ BARBAGLIA, S., Irineo di Lione e la comunicazione della fede cristiana, p. 125.

${ }^{223}$ IRINEU de Lião, Adversus haereses I, 9, 4; IV, 33, 10.

${ }^{224}$ SIMONETTI, M., Lettera e/o allegoria, p. 42.

${ }^{225}$ IRINEU de Lião, Adversus haereses II, 28, 3.

${ }^{226}$ PRINZIVALLI, E.; SIMONETTI, M., La teologia degli antichi cristiani, p. 15-16.

${ }^{227}$ IRINEU de Lião, Adversus haereses I, 9, 4.

${ }^{228}$ ORBE, A., Parábolas evangélicas en San Ireneo, p. 4-34.
} 
escondida no Pleroma, nas alturas celestes onde o Espírito puro conserva os divinos ensinamentos. Mas, para Irineu, mesmo sendo sublimes e espirituais, as Escrituras têm um conteúdo que revela os mistérios de um Deus encarnado na realidade humana, nos membros do Corpo de Cristo, que é a Igreja, o qual é um corpo humano e verdadeiro.

$\mathrm{Na}$ hermenêutica dos textos escriturísticos, para os gnósticos, a verdadeira compreensão deve conduzir o intérprete ao reino espiritual de onde veio, na criação deste mundo decaído; contrapondo a esta exegese vertical, Irineu propõe uma exegese horizontal, tanto do Novo como do Antigo Testamento, na direção de Jesus Cristo, ou seja, a Escritura equivale a uma parábola do futuro de Cristo encarnado em Jesus, primeiramente, e, depois, na Igreja, em cada batizado. Dessa forma, a Boa Nova busca a vida de cada uma das pessoas para conduzi-las a agregarem-se a Cristo e dele receberem a salvação já nesta vida e caminho para o Pai, assumindo a criação desprezada pelos gnósticos.

\subsection{2.}

\section{As referências bíblicas à Igreja}

Nos escritos de Irineu de Lião, Adversus haereses e Epideixis, a Sagrada Escritura é fonte essencial da argumentação. Tanto o Antigo como o Novo Testamento estão presentes, conjuntamente, na construção do pensamento e na refutação das heresias. Nesta parte, apresentaremos algumas referências bíblicas que Irineu utiliza para tratar as questões a respeito da Igreja.

Ao referir-se ao texto de Gn 2,8, Irineu afirma que "A Igreja é como o paraíso plantado neste mundo" 229 e relata que Deus plantou um jardim em Éden na versão da Septuaginta, jardim é traduzido por paraíso - pois, para o bispo de Lião, a Igreja está presente e realiza-se na existência terrestre; não é uma igreja espiritual, no mundo espiritual, como projetam os gnósticos, mas está presente no mundo. E é neste paraíso-jardim que os homens se alimentam para a vida, pois a Igreja os nutre com o verdadeiro alimento, as Escrituras divinas, que devem ser recebidas com humildade intelectual, pois o intelecto orgulhoso só alcança o alimento da discórdia e da dissensão dos hereges.

${ }^{229}$ IRINEU de Lião, Adversus haereses V, 20, 2. 
Aquele que realmente é filho da Igreja tem nela a nutrição suficiente e o caminho correto para atingir o verdadeiro conhecimento das coisas sagradas. Partindo da mesma perspectiva da Igreja como jardim-paraíso, o autor afirma que "Deus plantou a vinha do gênero humano primeiramente com a criação de Adão e a eleição dos patriarcas" ${ }^{230}$. Ou seja, utilizando-se da parábola dos vinhateiros (Mt 21,33-46; Mc 12,1-12; Lc 20,9-19), Irineu apresenta a criação como o jardim preparado por Deus para acolher o ser humano criado: a Lei mosaica é a forma de organizá-lo - Jerusalém como a torre de vigilância, a cerca delimitante seria o povo que deveria receber a mensagem de Deus, o lagar como o receptáculo do Espírito profético e os profetas eram os responsáveis por colherem o fruto de justiça, produzido pela vinha.

Porém, o povo da Antiga aliança não devolveu os frutos ao seu tempo. Consequentemente, a Igreja é a nova vinha do Senhor, é o jardim-paraíso que Ele mesmo plantou para a sua obra da criação, a fim de substituir os primeiros vinhateiros: "assim Deus entregou a vinha, não mais cercada, mas estendida ao mundo inteiro a outros vinhateiros que lhe entregarão os frutos no tempo devido" ${ }^{231}$. E não há mais uma única torre de guarda, mas a Igreja brilha em todos os lugares e em todos os lugares são escavados lagares, para receberem o Espírito Santo prometido pelo Senhor.

Na Adversus haereses, livro IV, 31, 1-3, Irineu interpreta a passagem de Gn 19,1-38, que relata a destruição de Sodoma e Gomorra e a fuga de Lot e sua família. Nessa passagem, Irineu apresenta duas referências diretas à Igreja: primeiramente afirma que a mulher de Lot, feita em estátua de sal, é a Igreja, que é o sal da terra, e esta está na região terrestre, entre os que se perderam (Sodoma e Gomorra) e entre os que se salvaram (Lot e suas filhas). Anteriormente, refere-se às duas filha de Lot, que se relacionaram com o pai, como as duas sinagogas (a dos judeus e a dos pagãos), que foram criadas pelo mesmo Pai e formam a Igreja. O bispo de Lião também afirma que a Igreja é mutilada pelas constantes perseguições, mas sempre se recupera e cresce ainda mais. Nesse momento, Irineu faz novamente a comparação com a perícope citada acima: "do mesmo modo que o seu tipo, a mulher de Lot, a estátua de sal”232.

\footnotetext{
${ }^{230}$ IRINEU de Lião, Adversus haereses IV, 36, 2.

${ }^{231}$ IRINEU de Lião, Adversus haereses IV, 36, 2.

232 IRINEU de Lião, Adversus haereses IV, 33, 9.
} 
$\mathrm{Na}$ mesma linha de interpretação, Irineu apresenta a chamada Igreja oriunda do paganismo, ou a partir da conversão dos pagãos, sendo os descendente de Jafé (Gn 9,18-29; 10,1-5) - filho mais novo de Noé, irmão de Sem (primogênito) e de Cam (ou Canaã, o amaldiçoado) - pois “"que Deus dilate Jafé, que ele habite nas tendas de Sem, e que Canaã seja seu escravo!'. (...) Dilatar significa, pois, o chamado dentre as nações, a saber, a Igreja"233. Sendo assim, a Igreja aqui recebeu, segundo Irineu, a bênção que foi dada a Jafé, e se torna a acolhedora de toda essa geração que não conhece o Senhor, passando a encontrá-lo no mandato da Igreja de ir a todos os povos. Complementando o que disse anteriormente, Irineu afirma que "o fruto da bênção de Jafé se manifestou na Igreja no chamado aos gentios que vivem em contínua obediência para poder habitar na casa de Sem, segundo a promessa de Deus" ${ }^{234}$.

A relação entre Abraão e a Igreja é muito presente nos escritos irineanos, muitas são as citações escriturísticas e comentários que o bispo de Lião apresenta a respeito dessa relação: "Deus introduz no Reino dos Céus Abraão e sua descendência, isto é, a Igreja que por meio de Jesus Cristo recebe a adoção e a herança prometidas a Abraão" 235 ; "a sua posteridade é a Igreja que, por meio do Senhor, recebe a filiação adotiva de Abraão"236; "a Igreja é a posteridade de Abraão; por isso, para que saibamos que tudo isso se realizará na Nova Aliança, que reunirá os que são salvos de todas as nações, suscitando das pedras filhos para Abraão",237.

Nas citações das diversas perícopes que tratam dos relatos de Abraão nas Escrituras, por vezes, como acima exemplificado, faz-se referência e relação a Abraão como o pai da fé da Igreja, que se torna sua herdeira, pois os primeiros recusaram o Jesus Cristo. Neste ínterim, o autor utiliza a figura de Abraão para mostrar que os descentendes do paganismo, ou dos "deuses das pedras", um povo destinado a ser santo, receberá, da Nova Aliança, a sua promessa de Povo Santo de Israel e será integrado ao edifício do Senhor ${ }^{238}$.

Em relação à perícope da história de Esaú e Jacó (Gn 25,19-34), Irineu afirma que Jacó “recebeu o direito da primogenitura recusada pelo irmão; assim o

\footnotetext{
${ }^{233}$ IRINEU de Lião, Epideixis 21.

${ }^{234}$ IRINEU de Lião, Epideixis 42.

${ }^{235}$ IRINEU de Lião, Adversus haereses IV, 8, 1 .

${ }^{236}$ IRINEU de Lião, Adversus haereses V, 32, 2.

${ }^{237}$ IRINEU de Lião, Adversus haereses V, 34, 1 .

${ }^{238}$ IRINEU de Lião, Epideixis 91-93.
} 
povo mais novo acolheu o Cristo como primogênito quando o povo mais velho o repelia dizendo: 'Não temos outro rei a não ser César",239. Ou seja, a Igreja que acreditou na Boa Nova anunciada por Jesus Cristo assumiu a herança da primitiva Aliança, e tornou-se o verdadeiro Povo de Deus.

Por isso, "em terra estrangeira nasciam as doze tribos, os filhos de Israel, porque também o Cristo devia gerar em terra estrangeira as doze colunas, fundamento da Igreja" ${ }^{\text {240 }}$. E a todos os relatos de Jacó no Antigo Testamento, o bispo de Lião os relaciona com Cristo e a Igreja: as ovelhas malhadas eram o salário de Jacó e o salário de Cristo são os homens que de várias e diferentes nações se reúnem no único redil da fé; Jacó teve filhos das duas irmãs, Cristo gerou filhos das duas leis; Jacó gostava da mais nova, Raquel, que simbolizava a Igreja pela qual Cristo sofreu.

No relato do êxodo do Povo de Deus do Egito (Gn 13,17-22), Irineu afirma que "a saída do Egito e tudo o que aconteceu pela ação de Deus foi a figura e o tipo do êxodo da Igreja, do paganismo; desta Igreja que, no fim, sairá daqui para entrar na herança que lhe dará, não Moisés, servo de Deus, mas Jesus, o Filho de Deus" ${ }^{241}$. Os sinais que acompanham o povo de Deus no deserto se tornarão verdadeiros com o novo Povo de Deus, formado e reunido pelo Cristo na Igreja, agora terrestre e, futuramente, no Reino de Deus.

Em outro relato, Irineu persevera na mesma relação, quando afirma que "os patriarcas e os profetas semearam as palavras que se referem a Cristo, e a Igreja ceifou, isto é, recolheu os frutos" ${ }^{242}$. Ou seja, a Igreja é a grande colheita de tudo que foi plantado na Antiga Aliança, e é nela que se concretiza e se conserva a verdadeira Palavra de Deus. Dessa forma, na Epideixis, Irineu afirma que “[Moisés] construiu o tabernáculo do testemunho, construção visível na terra das realidades espirituais e invisíveis do céu, figura da Igreja e representação profética das realidades futuras" ${ }^{\text {243 }}$. Essa construção que acompanha o povo no deserto como sinal da presença do Senhor é comparada pelo autor com Hebreus 8,5 e 10,1, demonstrando que Israel é tipo e figura da Igreja.

\footnotetext{
${ }^{239}$ IRINEU de Lião, Adversus haereses IV, 21, 3.

${ }^{240}$ IRINEU de Lião, Adversus haereses IV, 21, 3.

${ }^{241}$ IRINEU de Lião, Adversus haereses IV, 30, 4.

${ }^{242}$ IRINEU de Lião, Adversus haereses IV, 25, 3.

${ }^{243}$ IRINEU de Lião, Epideixis 26.
} 
Ao tratar das ofertas e oblações ao Senhor do Antigo Testamento (Dt 16,16; Ml 1,10-11; Os 6,6), o bispo de Lião afirma que "a Igreja é a única a fazer ao Criador oblação pura, oferecendo-a como ação de graças por meio de suas mesmas criaturas" 244 e justifica sua afirmação dizendo que as ofertas dos judeus já não têm mais valor, pois estes não receberam as palavras do Verbo de Deus.

Além disso, Irineu argumenta que os hereges falseiam nas suas assembleias, pois não fazem uma oblação verdadeira, visto que não aceitam a encarnação de Jesus Cristo. Contudo, na Adversus haereses IV, 17, 5-6, o bispo de Lião afirma que a verdadeira oferenda é o mandato deixado por Cristo, de fazer memória do seu Corpo e Sangue, o qual a Igreja recebeu dos apóstolos e leva ao mundo inteiro, como sacrifício puro e agradável a Deus.

Entretanto, em Adversus haereses IV, 18, 1-2, Irineu reforça que a oblação da Igreja não é mais apresentada por servos do Senhor, mas sim por filhos de Deus, pois os que receberam a graça da liberdade colocam à disposição do Senhor "tudo o que possuem, dando com alegria e generosidade não apenas as coisas de menor valor, pela esperança que têm das maiores; como aquela viúva tão pobre que pôs no cofre de Deus tudo o que possuía (Lc 21,4) "245.

$\mathrm{Na}$ perícope do profeta Oséias 1,2-9, Irineu afirma que o profeta se casou com uma prostituta, "para profetizar que a terra se prostituiria longe do Senhor, e que o Senhor haveria por bem formar a sua Igreja com tais homens e que a santificaria pelo contato de seu Filho, como aquela mulher o foi pelo contato com o profeta" ${ }^{246}$. Ou seja, a recapitulação que Jesus Cristo realizou na cruz manifesta o ato de santificar a Igreja de Deus, para que seus filhos sejam redimidos nela. Deste modo, atraiu à comunidade de Deus os filhos dispersos no paganismo. Tanto o filho da amada, como o da que não foi amada se reunirão em torno do seu Senhor, conforme promete o profeta Oséias, que Irineu cita a partir de Rm 9,25$26^{247}$.

A comparação da Igreja como Corpo de Cristo, presente na teologia paulina - 1Cor 12,12-30; Rm 12,4-5; Ef 4,4-6; Cl 2,16-23; Ef 5,21-33; G1 3,28-29 - é para Irineu uma referência em vários momentos, especialmente na refutação à falsa gnose, mostrando que "a verdadeira gnose é a doutrina dos apóstolos, é a

\footnotetext{
${ }^{244}$ IRINEU de Lião, Adversus haereses IV, 18, 4.

${ }^{245}$ IRINEU de Lião, Adversus haereses IV, 18, 2.

${ }^{246}$ IRINEU de Lião, Adversus haereses IV, 20, 12.

${ }^{247}$ IRINEU de Lião, Epideixis 91-93.
} 
antiga difusão da Igreja em todo o mundo, é o caráter distintivo do Corpo de Cristo, que consiste na sucessão dos bispos aos quais foi confiada a Igreja em qualquer lugar que ela esteja" ${ }^{248}$. Logo, é a verdadeira interpretação das Escrituras que possibilita compreender qual é a regula fidei e qual a verdadeira ekklesía do Senhor. E nem as mutilações e perseguições que a Igreja sofre, oferecendo a Deus muitos mártires, a fazem desanimar, pois ela recupera-se e cresce mais vigorosa.

Dessa forma, a Igreja afirma sua vocação de Corpo de Cristo, que, mesmo tendo os seus membros ceifados, a exemplo do seu Senhor, ressuscita para vida nova e agrega novos membros ao edifício do Senhor, pelo testemunho e pela $\operatorname{pregação~}^{249}$.

Assim, Irineu exorta seu amigo caríssimo e destinatário do livro, que confiante "foste remido pela carne de nosso Senhor e comprado pelo seu Sangue; 'permanece unido à cabeça, da qual recebe coesão e crescimento todo o corpo' $(\mathrm{Cl}$

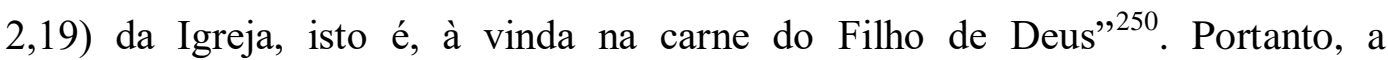
encarnação do Verbo de Deus e a sua entrega na cruz fundamentam a fé cristã e dão coesão à Igreja como Corpo de Cristo, para continuar sua obra neste mundo, e o próprio Senhor age nela e por ela ${ }^{251}$. "Com efeito, sobre todos, há o Pai e é Ele que é a Cabeça de Cristo; por meio de todos, há o Verbo que é a cabeça da Igreja”,252; “em todos, há o Espírito, e Ele é a água viva que o Senhor dá aos que nele creem com retidão, que o amam" ${ }^{, 253}$.

Em outras perícopes neotestamentárias, o bispo de Lião se utiliza de alguns textos para se referir à Igreja. No Evangelho de Lucas, Irineu afirma - ao citar os fatos ocorridos em Lc 8,40-56, especialmente o relato da ressurreição da filha de Jairo - que a Igreja transmite a vida verdadeira a partir de suas preces e de sua fidelidade ao Senhor: "toda a Igreja local pedindo fraternalmente com jejuns e orações, voltou o espírito do morto e foi concedida às orações dos santos a vida do homem" 254 .

No cântico do magnificat (Lc 1,46-47), Maria é apresentada por Irineu como a voz profética da Igreja que exulta no Senhor, pois "socorreu Israel, seu servo,

\footnotetext{
${ }^{248}$ IRINEU de Lião, Adversus haereses IV, 33, 8.

${ }^{249}$ IRINEU de Lião, Adversus haereses IV, 33, 9.

${ }^{250}$ IRINEU de Lião, Adversus haereses V, 14, 4.

${ }^{251}$ IRINEU de Lião, Adversus haereses IV, 32,1-2.

${ }^{252}$ IRINEU de Lião, Adversus haereses III, 16, 6 .

${ }^{253}$ IRINEU de Lião, Adversus haereses V, 18, 2.

${ }^{254}$ IRINEU de Lião, Adversus haereses II, 31, 2.
} 
lembrando de sua misericórdia, conforme prometera a nossos pais, em favor de Abraão e de sua descendência, para sempre" ${ }^{255}$ e esta verdade de fé se manifestará a partir da salvação que seu Filho Jesus inaugurará.

Em Atos dos apóstolos, por duas vezes (At 4,23; 15,7-11), a Igreja é comparada à reunião dos apóstolos e discípulos, como afirma Irineu: "os chefes dos sacerdotes soltaram Pedro e João, que voltaram aos outros apóstolos e discípulos do Senhor, isto é, à Igreja" e "Paulo e Barnabé foram a Jerusalém para tratar desta questão com os outros apóstolos. Reuniu-se toda a Igreja” ${ }^{, 256}$. Esta reunião torna-se mais que um conjunto de pessoas num mesmo lugar; constitui uma assembleia dos eleitos, uma reunião dos fiéis, a igreja local como sinal da Igreja, e esta não se reúne como amigos ou conhecidos, mas como uma comunidade de fé, que reconhece a graça e a ação do Espírito de Deus em seu meio, e que eleva a Deus mãos e vozes unânimes (Lc 4,24-28) para bendizer o Senhor. Sendo assim, dirá Irineu:

esta é a voz da Igreja, da qual tiveram origem todas as igrejas; estas as vozes da Cidade mãe dos cidadãos da Nova Aliança; estas eram as vozes dos apóstolos, as vozes dos discípulos do Senhor; eles eram verdadeiramente perfeitos, por terem sido tornados perfeitos pelo Espírito, depois da ascensão do Senhor; e invocavam a Deus que fez o céu, a terra e o mar, anunciado pelos profetas e o seu Filho Jesus, que Deus ungiu, e não conheceram outro Deus ${ }^{257}$.

É pela voz da oração, da pregação, do anúncio, do ensino, do testemunho que esta Igreja é formada e forma outras, pois a ação do Espírito de Deus nela, a partir da unção do Alto, tornou-a um vaso precioso e um depósito da graça de Deus. “Onde está a Igreja, aí está o Espírito de Deus, e onde está o Espírito de Deus ali está a Igreja e toda a graça" ${ }^{258}$. Por isso, nela o Senhor escolheu todos os ministérios (1Cor 12,27-30), para que espalhem que o "dom de Deus foi confiado à Igreja, como o sopro de vida inspirado na obra modelada, para que sejam vivificados todos os membros que o recebem" 259 .

Assim, a Igreja gera um grande número dos que serão salvos e apresenta à sinagoga estéril, que não produziu filhos ao seu Senhor, a alegria de ser a Esposa

\footnotetext{
${ }^{255}$ IRINEU de Lião, Adversus haereses III, 10, 2.

${ }^{256}$ IRINEU de Lião, Adversus haereses III, 12, 5; III, 12, 14.

${ }^{257}$ IRINEU de Lião, Adversus haereses III, 12, 5.

${ }^{258}$ IRINEU de Lião, Adversus haereses III, 24, 1.

${ }^{259}$ IRINEU de Lião, Adversus haereses III, 24, 1.
} 
fiel $(\mathrm{Gl} 4,27)$ ao seu Esposo, que canta de alegria, pois numerosos são seus descendentes $^{260}$.

Os escritores anteriores ou contemporâneos a Irineu de Lião permitem compreendermos que a ideia de Igreja que existia nos primeiros dois séculos do cristianismo pauta-se por uma perspectiva de Igreja constituída como comunidade, como o conjunto de fiéis batizados, reunidos em Cristo Jesus e na sua proposta.

O anúncio da Boa Nova revelada por Jesus Cristo possibilitou que estes primeiros cristãos compreendessem que o importante não era uma instituição, aos moldes judaicos, mas sim uma agregação de pessoas que reconheceram em Cristo e na sua Palavra o caminho, a proposta, o modelo de vida nova, e que, abertos ao Espírito Santo, têm a capacidade de viver essa nova vida já na terra, aguardando a vinda definitiva do Senhor.

A imagem da Igreja como a mulher de $\operatorname{Lot}^{261}$, que se transformou numa estátua de sal e que é entendida por Irineu como o intermédio entre a destruição de Sodoma e Gomorra, em virtude da depravação e do afastamento de Deus, e a salvação que os anjos empreenderam a Lot e suas filhas, possibilita confirmar que essa perspectiva eclesiológica não é institucional e ordeira, mas orgânica.

A Igreja é a comunidade viva dos fiéis em Cristo, e estes fiéis precisam conhecer e aprofundar-se neste Cristo para não se perderem. Eles precisam receber o gosto, o sal, o novo sabor da vivência fraterna e do alimento que o Senhor concede aos que creem. Este corpo vivo não cresce por proselitismo ou poder, cresce porque muitos conhecem a Verdade que o Verbo de Deus, seus apóstolos e discípulos anunciaram. Logo, agregam-se ao verdadeiro Caminho, que se temporiza na terra, mas aponta para o Reino Definitivo, e assim escolhem e acolhem a verdadeira vida, que nos vem de Deus.

Neste capítulo, foram apresentadas as fontes do pensamento irineano, em seus antecedentes patrísticos e bíblicos. Primeiramente a compreensão de ekklesía no Antigo Testamento que partiu de dois termos hebraicos, 'eda que representa a totalidade da comunidade judaica, e qahal que é a comunidade convocada. $\mathrm{Na}$ sequência, foi apresentado dois aspectos fundamentais da compreensão de

${ }^{260}$ IRINEU de Lião, Epideixis 94.

${ }^{261}$ IRINEU de Lião, Adversus haereses IV, 31, 3. 
ekklesía no Novo Testamento: como assembleia de Deus e como um vínculo comunitário existente entre os crentes em Cristo.

Em relação às fontes patrísticas a compreensão da Igreja como assembleia e agregação assumem várias interpretações. Clemente afirma que a Igreja se traduz na vida de cada fiel, e todos numa comunhão de sentimentos e de pensamentos. É neste amor que a Igreja de Cristo encontra a paz, a unidade, a fraternidade e se reúne como novo Povo de Deus. No epistolário de Inácio de Antioquia se compreende a Igreja em duas dimensões fundamentais: a sua unidade como comunidade liderada pelos seus dirigentes e a eucaristia como realidade constitutiva desta comunidade. Em Hermas, a agregação da Igreja é o que possibilita a salvação. A comunidade reúne as diversas categorias de fiéis para formar a assembleia do Senhor, na qual não há distinção entre as pessoas, pois todos em Cristo formam o grande edifício de fé. Justino mostra que a comunidade se reúne nas orações, nas celebrações e no socorro dos mais necessitados. No entanto, pelo batismo é que se compreende a profundidade da comunidade, que pelo banho da regeneração e pela eucaristia agrega os irmãos em Jesus Cristo. Em Melitão de Sardes a Igreja é receptáculo da verdade que Deus revelou e o Corpo de Cristo que no mistério pascal celebra essa pertença ao Senhor. No epitáfio de Abércio a compreensão de agregação ganha contornos muito importantes pela antiguidade e também elementos que o autor apresenta. A comunidade é pastoreada pelo Cristo, "casto pastor" que enxerga a todos; ela tem em Roma a rainha de grande beleza, mas também nela se estabelece a representação universal de toda Igreja peregrina, rumo à Jerusalém celeste; ela reúne os marcados com o sigilo que lavaram suas vestes no sangue do cordeiro; ela é aquela que tem irmãos em todos os lugares, sempre prontos a partilharem a alegria, a fé e o alimento: pão, peixe e vinho. Em contraposição, a agregação a um grupo gnóstico nasce de uma experiência existencial e individual, pois a pessoa sente a necessidade de se libertar da prisão do mundo material, das suas adversidades, para retomar seu lugar no Pleroma.

Em relação às fontes bíblicas, Irineu é um dos primeiros Padres da Igreja a se servir de um vasto uso das Sagradas Escrituras, não somente por citações, mas também por causa da compreensão da continuidade da revelação reconhecida em ambos os testamentos. A sua hermenêutica dos textos escriturísticos parte da Tradição qual um princípio universal e fundante, sobre tudo porque precisa 
combater os marcionitas que ignoram o Deus que chamou Abraão e os gnósticos que utilizam da alegoria para descobrir nas Sagradas Escrituras os segredos escondidos. Por meio da tipologia, Irineu compreenderá que a Igreja foi revelada nas Sagradas Escrituras, não somente no Novo Testamento, mas também prefigurada nos relatos veterotestamentários. 


\section{3. \\ A ortodoxia de Irineu de Lião}

As fontes apresentadas no capítulo precedente, tanto na análise dos Padres da Igreja anteriores e contemporâneos a Irineu, quanto nos textos escriturísticos e nas suas referências presentes na obra do bispo de Lião prepararam o caminho para a construção e interpretação da obra irineana.

O entendimento do contexto patrístico nos dois primeiros séculos motivou uma nova perspectiva de leitura do texto de Irineu, enquanto o contexto institucional e hierárquico ainda não era preponderante. A partir desse ponto de vista, ressalta-se a estrutura comunitária, centrada na mensagem de Jesus, que convidava as pessoas a viverem um projeto de vida nova, pelo batismo e pela fraternidade. A Palavra de Deus se torna o alicerce do anúncio dessa Boa Nova e, ao mesmo tempo, convoca os fiéis a buscarem redefinir sua vida numa nova perspectiva.

Sendo assim, sob o ponto de vista da eclesiologia, esta releitura dos textos de Irineu proporciona um novo olhar sobre a obra. Um dos benefícios dessa leitura se estabelece no fato de poder compreender uma doutrina original e antiga sobre a Igreja.

Por meio do estudo e da investigação eclesiológica sobre a Adversus haereses e sobre a Epideixis, sete novos itens surgiram para apresentar a hermenêutica irineana, além da apresentação da gnose valentiniana e da sua estruturação no Pleroma. A Igreja e suas características, a importância do batismo, a regula fidei, a atuação da Igreja, a Tradição apostólica, a sucessão apostólica e a Virgem Maria no mistério da recapitulação de Jesus Cristo são os novos itens nascidos desse olhar eclesiológico sobre a obra de Irineu. Para tanto, foram utilizados comentadores e autores que já abordaram a obra do bispo de Lião, principalmente quando estes refletiram sobre a Igreja. 
3.1.

A hierarquia do Pleroma gnóstico

\subsection{1}

A gnose valentiniana de Ptolomeu, um modelo de estudo

Platão utilizou o substantivo gnosis ou o adjetivo gnostikos para mostrar um modo próprio de conhecimento, que se diferenciava do conhecimento prático ${ }^{262}$. Ou seja, o termo foi utilizado para descrever o conhecimento teórico, diferenciando-o de outros modelos cognitivos. Em nenhum momento apresentou a ideia de uma pessoa ou de um grupo de pessoas que tivessem acesso a um conhecimento exclusivo, ressaltando que o conhecimento gnóstico haveria de ser, por extensão, o tipo de experiência advinda da gnose como ciência teórica ${ }^{263}$.

Irineu afirma, ao se referir aos que ele deve refutar, que os maus intérpretes da fé "sob pretexto de gnose afastam muitos daquele que criou e pôs em ordem este universo, como se pudessem apresentar alguma coisa mais elevada e maior que o Deus que fez o céu e a terra e tudo o que eles encerram" ${ }^{\text {,64 }}$. Isso mostra que o bispo de Lião reforça que estes, sob o pretexto de gnose, apresentavam uma doutrina que desvirtuava as pessoas, de modo especial os cristãos, do verdadeiro conhecimento.

O termo "gnóstico", para Irineu de Lião, se referia aos "intelectualizados", e só posteriormente autores cristãos utilizaram este termo para conotar os seguidores de grupos heréticos - como identidade de grupo. Nesse sentido, o termo gnose era utilizado apenas para explicitar a diferença entre o conhecimento divino revelado e o falso conhecimento dos gnósticos.

Realmente, o termo gnosticismo não foi citado por Irineu de Lião, mas foi cunhado no século XVII por Henry More (1614-1687) para aglutinar todos os personagens que Irineu descreveu e refutou, juntamente com aqueles que haveriam de surgir posteriormente ${ }^{265}$. Muitos estudos atuais tentaram reconstruir e definir o que se entendeu pelo termo gnosticismo, de modo especial depois das

\footnotetext{
${ }^{262}$ Para a descrição dessa parte foram utilizados escritos presentes em PIACENTE, L., O encontro do cristianismo com a cultura clássica, p. 24-34.97-110; ROUSSEAU, A.; DOUTRELEAU, L., Contre lês hérésies livre 1, p. 113-130; DANIÉLOU, J., La teologia del giudeo-cristianesimo, p. 122-128.

${ }^{263}$ RÄISÄNEM, H., El nacimiento de las creencias cristianas, p. 80-82.

${ }^{264}$ IRINEU de Lião, Adversus haereses I, prefácio, 1.

${ }^{265}$ BRAKKE, D., Los gnóstikos, p. 42.
} 
descobertas de Nag Hammadi ${ }^{266}$. A conferência de Messina em 1966 concluiu pelo entendimento do gnosticismo como um sistema aparentemente cristão, “com uma série coerente de características: uma faísca divina presente na humanidade e um movimento descendente do divino" 267 , contextualizados no segundo século.

Sendo assim, o gnosticismo carregava uma concepção dualista que se misturava com um fundo monista, expressando-se num movimento de desdobramento e de integração. Em virtude disso, o gnosticismo podia pertencer tanto ao judaísmo ou ao cristianismo, quanto a nenhum desses, pois, nesse movimento de desdobramento, as teorias se adaptavam para se vincular às doutrinas que eram mais úteis no processo de explicação do sistema gnóstico.

Outros estudos mostraram que o gnosticismo teve suas raízes em bases précristãs, mesopotâmicas, judias, gregas e foi uma tendência filosófica, cultural e religiosa muito ampla, que avançou por todos os limites do Império Romano, aglutinando várias correntes de pensamento. Apesar disso, teve um denominador comum: a busca por um conhecimento salvador.

Dentro do ambiente cristão, a partir do século II, o gnosticismo desdobrouse em diversos grupos, com doutrinas e escritos próprios - Evangelhos, cartas, apocalipses -, que logo foram considerados heréticos e condenados ao desaparecimento $^{268}$. Sem buscar unificar esses grupos, outros estudos os identificaram como uma categoria social no movimento cristão primitivo dos dois primeiros séculos. Tal categoria não gozava de uniformidade, nem de unidade no pensamento, no rito e na doutrina. Mesmo assim, alguns membros dessas Comunidades foram conhecidos como gnósticos e também assim se nomeavam, por compartilharem conhecimentos secretos e terem ritos mistéricos próprios.

Essa foi uma forma de descrever o movimento gnóstico sem delimitar suas teorias e propostas, para unificação numa religião ou grupo que agregasse a todos. Contudo, buscou-se identificar que grupos diversos e com objetivos próprios tinham a gnose como princípio comum e assim se identificavam ${ }^{269}$.

Além disso, Etienne Gilson, ao comentar sobre a questão gnóstica dentro do cristianismo, afirmou que nada é mais cristão do que a "ambição de aprofundar a

${ }^{266}$ ORBE, A., Gli apocrifi cristiani a Nag Hammadi, p. 84-109, o autor apresenta uma reflexão sobre os textos encontrados e seus conteúdos.

${ }^{267}$ BRAKKE, D., Los gnóstikos, p. 43.

${ }^{268}$ SOTOMAYOR, M.; UBIÑA, J., Historia del cristianismo I, p. 235-236.

${ }^{269}$ BRAKKE, D., Los gnósticos, p. 54. 
fé pelo conhecimento, desde que o conhecimento se estabeleça no interior da fé; mas não é cristão considerar a fé como um arcabouço provisório, do qual, desde esta vida, o conhecimento racional poderá nos dispensar,"270. Assim, o autor explicitou que entre as duas concepções de conhecimento possíveis, neste período inicial da intelecção cristã, uma buscou submeter-se à fé para perscrutar o mistério e outra pretendeu substituir a fé. E nesta última forma de pensamento dentro do cristianismo nascente estavam os grupos gnósticos ${ }^{271}$.

Portanto, a unificação do gnosticismo como uma religião ou grupo bem delimitado se mostra incongruente, sendo mais apropriado pensar na existência de diversos grupos gnósticos, em regiões geográficas diversas, com mestres de formação e características diferenciadas, com doutrinas, interpretações e tradições das mais variadas. Nesse sentido, Irineu traz os exemplos de Ptolomeu, que tendia a uma reflexão filosófica, e de Marcos, que estava envolvido com rituais mágicos.

O bispo de Lião identifica em suas obras vários grupos e tradições diferentes, porém o que daria aos diversos grupos gnósticos uma unificação, principalmente nos três primeiros séculos da era cristã, era a presença no seio do cristianismo nascente, a participação das Comunidades, e ainda a utilização das suas estruturas e seus ritos para difundirem seus conhecimentos.

Segundo o pesquisador e tradutor das escrituras gnósticas descobertas em Nag Hammadi, Bentley Layton, podem ser identificados vários grupos gnósticos com metodologias, teorias e regiões geográficas próprias. Um destes grupos, possivelmente o mais antigo, era inspirado na filosofia gnóstica de Basílides, que atuou em Alexandria entre 132-135 d.C., levando para esta cidade um movimento cristão muito convincente e organizado, que perdurou até o século IV. Ele ensinava um mito cosmogônico, além de apresentar uma filosofia ética com influências estóicas, ao tratar dos ensinamentos cristãos. Fazia uso dos textos das Sagradas Escrituras, como também da filosofia médio-platônica e pitagórica, para elaborar a sua doutrina da salvação.

Esse ecletismo é muito próprio dos grupos filosóficos presentes em Alexandria entre o final da era pagã e os primeiros séculos da era cristã, como pode ser constatado nos escritos de Clemente de Alexandria e também entre os

${ }^{270}$ GILSON, E., A filosofia na idade média, p. 26.

${ }^{271}$ GILSON, E., A filosofia na idade média, p. 25-27. 
grupos gnósticos ${ }^{272}$. O autor apresentou, ainda, outro grupo de gnósticos oriundos da Tradição Cristã presente na Mesopotâmia do Norte, tendo o Apóstolo Tomé como mestre fundamental. Por isso, dois escritos eram basilares para o grupo: o Evangelho segundo Tomé e o Livro de Tomé. Esses textos em nada exprimiam o mito gnóstico clássico, mas apresentavam um conceito místico de salvação pelo autoconhecimento, em função do qual se organizam as bases da escola valentiniana $^{273}$.

Valentim (100-175 d.C.) nasceu em Phrebonis, delta do Egito, próximo a Alexandria, capital da cultura helenista, na qual se formou com boa educação grega e também onde, possivelmente, teve contato com o filósofo cristão Basílides. Nessa mesma cidade, estabeleceu o contato com as obras do alegorista e filósofo judeu-alexandrino Fílon de Alexandria, aprendendo o platonismo, por meio da sua interpretação helenista-judaica da Bíblia.

Foi em Alexandria que Valentim iniciou sua carreira de mestre ${ }^{274}$. Entre 136-140, Valentim emigrou para Roma, constituindo uma escola filosófica, mas também conquistou certa integração com a comunidade cristã romana. Irineu confirma esse fato, ao afirmar que "Valentim foi a Roma no pontificado de Higino, teve o sucesso maior no período de Pio I e ficou aí até Aniceto"275.

Segundo D. Brakke, Valentim foi cogitado para o episcopado na comunidade romana, mas esse fato não se efetivou. Ora, sua participação na Igreja de Roma é uma incógnita, pois não existem outros registros, além do citado, nem de condenação nem de proibição para que pudesse ensinar ${ }^{276}$. Autores posteriores narram virulentos ataques entre os cristãos romanos e os seguidores de Valentim, mas ele morreu sobriamente em Roma, em 165, aproximadamente.

Em ambas as cidades, Roma e Alexandria, a doutrina valentiniana floresceu com ilustres seguidores - por exemplo: Ptolomeu e Heracleon em Roma, Teodoto e Marcos em Alexandria - e muitas escolas perseveraram até o século VII, formando exegetas bíblicos e teólogos, que defendiam as doutrinas do mestre diante dos ataques cristãos ${ }^{277}$. O pensamento valentiniano se constituiu com características peculiares, não se adaptando a nenhum outro grupo gnóstico. A

${ }^{272}$ LAYTON, B., As escrituras gnósticas, p. 491-493.

${ }^{273}$ LAYTON, B., As escrituras gnósticas, p. 425-431.

${ }^{274}$ LAYTON, B., As escrituras gnósticas, p. 259; p.317.

${ }^{275}$ IRINEU de Lião, Adversus haereses III, 4, 3.

${ }^{276}$ BRAKKE, D., Los gnósticos, p. 156-157.

${ }^{277}$ LAYTON, B., As escrituras gnósticas, p. 263. 
genialidade e a eloquência grega de Valentim foram muito peculiares e reconhecidas publicamente até pelos seus adversários. Por isso, os poucos fragmentos que restaram da sua obra, mesmo sendo de uma abrangência e de variedade expressiva segundo o gênero literário, conservam o seu estilo.

Os valentinianos, segundo Y. Andia, chamavam-se pelo epíteto de cristãos tradicionais e reuniam-se em grupos conduzidos por um mestre. Liam e comentavam as Escrituras Sagradas, além de participarem de momentos de ensino e de debate. As formas da literatura valentiniana eram tipicamente acadêmicas: tratado metafísico, epístola filosófica, comentário bíblico, poemas místicos e antologia. A principal característica literária foi o uso da alegoria, que não nasceu com a escola valentiniana, mas fora usada por ela em larga escala, na interpretação dos textos do Antigo e Novo Testamento.

A tradição cristã, por meio dos Padres da Igreja, combateu diretamente os valentinianos, sugerindo que a influência dessa escola deveria ser grande, pois muitos foram os escritos contra a doutrina valentiniana, a começar por Irineu de Lião, Clemente de Alexandria, Tertuliano, Epifânio de Salamina, Hipólito de Roma e outros ${ }^{278}$.

Irineu é o primeiro autor a chamar um grupo de pessoas de gnósticos, segundo D. Brakke, porém termina por construir uma visão confusa sobre eles, pois o bispo de Lião afirma, por um lado, que todos os gnósticos formam um grande grupo reunido em torno das ideias de Valentim, enquanto, por outro lado, especifica os valentinianos como um sistema diferente dos outros grupos gnósticos. Algumas coisas se tornam claras para Irineu, conforme Pose, quais sejam: a escola valentiniana era a que mais incomodava as comunidades cristãs pela sua presença dentro do movimento cristão nas diversas realidades onde se inseriu $^{279}$; e os ensinamentos de Valentim, interpretados e aprofundados por Ptolomeu, foram os mais nocivos, pois, segundo Irineu, "a doutrina [de Ptolomeu] é como que a flor da escola de Valentim"280.

Ptolomeu ou Tolomeu foi considerado um dos primeiros e mais brilhantes seguidores de Valentim, não necessariamente porque a sua descrição fosse fiel aos ensinos do mestre, já que entre os mestres gnósticos não há essa preocupação em

\footnotetext{
278 ANDIA, Y., L’hérésie et as réfutation selon Irénée de Lyon, p.620-630; LAYTON, B., As escrituras gnósticas, p. 317-325; BRAKKE, D., Los gnósticos, p. 181-188.

${ }^{279}$ BRAKKE, D., Los gnósticos, p. 58-64; POSE, E., La siembra de los Padres, p. 583-600.

${ }^{280}$ IRINEU de Lião, Adversus haereses I, prefácio, 2.
} 
relação à fidelidade aos ensinamentos, permitindo a cada um em sua realidade, cultura, formação filosófica e religiosa construir a própria reflexão a partir do que já tinha sido aprendido. Em contrapartida, os detalhes desse tipo de afirmação se tornam obscuros, pois a descrição dos mitos gnósticos, segundo Ptolomeu e Valentim, só é acessível pela interpretação de Irineu e Tertuliano, o que torna limitada a comparação dos sistemas em suas particularidades ${ }^{281}$.

Independentemente disso, segundo D. Brakke, é possível afirmar que Irineu está bem familiarizado com os ensinamentos dos valentinianos e apresenta Ptolomeu como o grande representante deste pensamento. Além disso, estudiosos do gnosticismo e historiadores afirmam que a descrição presente na obra de Irineu sobre o sistema gnóstico-valentiniano se assemelha muito com os fragmentos encontrados em Nag Hammadi ${ }^{282}$.

O sistema fundamental dos gnósticos é apresentado por Irineu na Adversus haereses I, 1-7.11-12, compreendendo nada mais que o relato do mito gnóstico segundo Ptolomeu e a escola valentiniana.

A cosmologia valentiniana ${ }^{283}$ narrada por Irineu expõe a teoria da criação gnóstica, que apresenta uma divisão entre o mundo espiritual - o Pleroma (completude, plenitude divina) - “impronunciável e não conhecido, invisível” e o mundo decaído, criado pelo Demiurgo. No princípio, existe "um Éon perfeito, anterior a tudo, que chamam Protoprincípio, Protopai e Abismo. Incompreensível e invisível, eterno e ingênito que se manteve em profundo repouso e tranquilidade durante uma infinidade de séculos" ${ }^{\text {285 }}$. Ele se mantém unido a uma Enoia, chamada Graça ou Silêncio, conservando assim a estrutura gnóstica na qual os seres espirituais (éons) existem sempre em pares compostos por um elemento masculino e por outro feminino, relacionando-se por conjugação (sizígia).

Conforme interpretações médio-platônicas, toda emanação deve ser realizada pela conjugação de um par masculino-feminino, porque o éon feminino gera a essência na emanação, enquanto a forma é originada no éon masculino, para completar a geração ${ }^{286}$. Embora esta interpretação não esteja presente nos

\footnotetext{
${ }^{281}$ LAYTON, B., As escrituras gnósticas, p. 327.

${ }^{282}$ BRAKKE, D., Los gnósticos, p. 65.

${ }^{283}$ CHIAPPARINI, G., Valentino gnóstico e platônico, p. 297-306.

${ }^{284}$ IRINEU de Lião, Adversus haereses I, 1, 1.

${ }^{285}$ IRINEU de Lião, Adversus haereses I, 1, 1.

${ }^{286}$ CHIAPPARINI, G., Valentino gnóstico e platônico, p. 62-63.67; DONADON, D., Adversus haereses, p. 37.
} 
escritos de Irineu, a filosofia da época, que influenciava demasiadamente as interpretações gnósticas, a atesta.

O Abismo "teve o pensamento de emitir, dele mesmo, um Princípio de todas as coisas; essa emissão, de que teve o pensamento, depositou-a como semente no seio de sua companheira, o Silêncio" ${ }^{287}$. Sendo assim, gerou a Mente (nous), "que é semelhante e igual ao emanador e contém a magnitude do Pai. Este Nous foi também chamado Unigênito, Pai e Princípio de todas as coisas"288. A Mente e a Verdade (aleteia) originarão todas as coisas e, a partir deste momento, formando a Tétrada primeva, que é fundamental e, à medida que a Mônada se mostra inacessível, pertence à Mente e à verdade o aparecimento das emanações diretamente delas ou por sucessão.

Por isso, Irineu cita a nomeação valentiniana da Mente também de Pai, Unigênito, Princípio de todas as coisas. O Unigênito tendo aprendido como fora emanado, por conjugação, gerou o Verbo $(\log o s)$ e a Vida (zoé), que geraram, da mesma forma, o Homem (anthropós) e a Igreja (ekklesía) formando, assim, a Ogdôada constituída pela Tétrada primitiva inacessível e as outras quatro emanações subsequentes.

O Pleroma completou-se com duas realidades novas: a Década - dez éons emanados unicamente pela conjunção do Verbo e da Vida - formada por: Profundo e Mistura; Não-envelhecimento e União; Natural e Prazer; Imóvel e Misturado; Único-gerado e Bem-aventurança; e a Duodécada - doze éons emanados unicamente por sizígia do Homem e da Igreja - constituída por: Consolador e Fé; Paternal e Esperança; Maternal e Amor; Louvor e Entendimento; Eclesiástico e Felicidade; Desejado e Sabedoria (Sophia).

Para Irineu esta "é a teoria errada deles a respeito dos trinta éons impronunciáveis e não conhecíveis. Segundo eles, este é o Pleroma invisível e espiritual, com a sua tríplice divisão em Ogdôada, Década e Duodécada"289. Numa alegoria a respeito dos trinta éons, Irineu afirma que os valentinianos, para justificarem a invisibilidade e o silêncio do mundo espiritual, fazem uma relação como os anos da vida oculta de Jesus em Nazaré, marcados pelo silêncio e desconhecimento.

\footnotetext{
${ }^{287}$ IRINEU de Lião, Adversus haereses I, 1, 1.

288 IRINEU de Lião, Adversus haereses I, 1, 1.

${ }^{289}$ IRINEU de Lião, Adversus haereses I, 1, 3.
} 
Além disso, na parábola dos operários enviados à vinha (Mt 20,1-16), a doutrina valentiniana também interpreta o mistério dos trinta éons que compõem o Pleroma, pois os operários foram chamados às correspondentes horas: $1+3+6+$ $9+11=30$. Dessa forma, os valentinianos defendem e justificam a existência do mundo espiritual composto pela Ogdôada (Tétrada + Tétrada), Década e Duodécada, e sua realidade divina, fora da matéria ${ }^{290}$.

Seguindo a descrição ${ }^{291}$, Irineu descreve uma afirmação dos gnósticos que o único Éon que conhecia o Pai era o Unigênito, permanecendo invisível e intangível para os outros. O desejo por conhecer a origem, "o gerador de sua semente e contemplar aquele que é a Raiz sem princípio" ${ }^{292}$ provocou um desequilíbrio no Pleroma.

Primeiramente, o Unigênito, no seu amor e adoração pelo Protopai, desejou revelá-lo a todos, mas foi impedido pelo Silêncio. Enquanto isso, a Sabedoria, “o último e mais novo Éon da Duodécada, excitou-se grandemente e sofreu a paixão mesmo sem o abraço do cônjuge, o Desejado; essa paixão, nascida ao redor do Nous e da verdade, propagou-se neste Éon" ${ }^{293}$. Tornou-se em aparência de amor e foi estabelecer contato com o Protopai para conhecer sua magnitude. Como foi impedida pelo Protopai, visto que "seria finalmente absorvida pela doçura do Pai e dissolvida na substância universal" ${ }^{294}$, a Sabedoria entrou em grande angústia e do excesso de amor que gerou em si nasceu, sem sizígia, um ente amorfo, chamado Entímese ${ }^{295}$, que foi separada da Sabedoria e jogada no vazio fora do Pleroma.

Para restabelecer o equilíbrio no Pleroma, o Pai gerou, sem sua conjugação, outra realidade, “o Limite que é chamado também Cruz, Redentor, Emancipador, Delimitador e Guia. E é justamente por meio do Limite que Sofia foi purificada e reintegrada na sizígia"296. O Limite exerce a função de impedir o acesso à Mônada original, mas também é ele que será o divisor entre o Pleroma e o vazio onde a Entímese da Sofia foi lançada. Ademais, impedirá que outros éons tivessem a mesma ação desequilibrada. Ptolomeu afirma que, pela crucificação de Jesus, o

${ }^{290}$ LAYTON, B., As escrituras gnósticas, p. 334; CHIAPPARINI, G., Valentino gnóstico e platônico, p. 72-74.

${ }^{291}$ IRINEU de Lião, Adversus haereses I, 2, 1-6.

${ }^{292}$ IRINEU de Lião, Adversus haereses I, 2, 1.

${ }^{293}$ IRINEU de Lião, Adversus haereses I, 2, 2.

${ }^{294}$ IRINEU de Lião, Adversus haereses I, 2, 2.

${ }^{295}$ Entímese ou Acamot. Entímese, em grego, vem da raiz da palavra sabedoria.

${ }^{296}$ IRINEU de Lião, Adversus haereses I, 2, 4. 
Cristo ultrapassou o Limite e restaurou a Entímese, levando-a de novo ao Pleroma.

Dois outros éons foram criados pelo Protopai por meio do Unigênito, para que nenhum éon voltasse a sofrer tal paixão: Cristo e Espírito Santo. O Cristo teve a missão de explicar aos éons a natureza da conjugação entre eles e também o conhecimento do Unigênito, e proclamou o conhecimento do Pai no meio deles, mostrando que ninguém poderia vê-lo ou entendê-lo a não ser o Unigênito. "O Espírito Santo os ensinou a serem agradecidos, tendo se igualado a todos, e os conduziu ao verdadeiro descanso. Assim estabelecidos, todos dizem que com grande alegria entoaram hinos ao Pai, ${ }^{297}$.

Neste estado, os éons colocaram o seu melhor em honra do Protopai e emanaram, conjuntamente, a mais bela e perfeita estrela do Pleroma, Jesus. Também chamado Cristo, Salvador e Verbo, Ele era guardado por anjos que os éons emanaram.

$\mathrm{Na}$ terceira parte do primeiro livro, Irineu retoma o que já fora dito anteriormente e mostra como os gnósticos se utilizam de textos da Palavra de Deus "querendo adaptar as belas palavras da Escritura às suas más interpretações" ${ }^{298}$, tanto dos Evangelhos, das Cartas do Apóstolo, como dos livros da Lei e dos Profetas.

Por exemplo, os gnósticos interpretavam que os doze anos de Jesus ao subir ao Templo (Lc 4,42-46) e a eleição dos doze apóstolos (Mt 10,2) representavam a Duodécada; o relato da traição de Judas, o décimo segundo Apóstolo, com a paixão da Sabedoria, o décimo segundo éon. Em outra passagem, cita Paulo relatando sobre a cruz, "a linguagem da cruz é loucura para aqueles que se perdem, mas para aqueles que se salvam é poder de Deus" ${ }^{299}$, mostrando assim a presença do limite, também chamado cruz, que manifestou o poder de Deus.

O surgimento da matéria ${ }^{300}$, segundo a descrição valentiniana citada por Irineu, deu-se a partir da decisão da Entímese (Acamot) em voltar ao mundo espiritual. Porém, quando foi colocada no vazio, além do limite, o Cristo e o Espírito lhe modelaram uma substância corpórea sem gnose e, diante da tristeza e da angústia por não mais pertencer ao Pleroma, a Entímese decidiu mudar.

\footnotetext{
${ }^{297}$ IRINEU de Lião, Adversus haereses I, 2, 6.

${ }^{298}$ IRINEU de Lião, Adversus haereses I, 3, 6.

${ }^{299}$ IRINEU de Lião, Adversus haereses I, 3, 5.

${ }^{300}$ IRINEU de Lião, Adversus haereses I, 4,1-5,7.
} 
Desse modo, "da conversão tiveram origem todas as almas do mundo; e do Demiurgo, bem como do temor e da tristeza, todo o resto [e] das lágrimas as substâncias úmidas, do sorriso as lúcidas, e da tristeza e do temor os elementos corpóreos do mundo" 301 .

Continuando a sua disposição de voltar ao Pleroma, Acamot clamou ao Cristo e este enviou Jesus com os anjos que o guardavam. Este terminou a obra iniciada pelo Cristo e o Espírito, modelou-lhe segundo a gnose e deu-lhe a capacidade de criação por meio da conjugação de Jesus e seus anjos, dando origem aos três elementos: "o primeiro proveniente da paixão, e era a matéria; o segundo, da conversão, e era o psíquico; enfim o terceiro, gerado por Acamot, era o pneumático"302.

Do elemento psíquico foram formados os animais e da matéria os seres materiais, tudo feito por Acamot à semelhança do Pleroma. Depois de ter separado as essências incorpóreas, criou as coisas celestes, enquanto também o Demiurgo, que residia no sétimo céu (Hebdômada), era considerado o Pai e Deus do que estava fora do Pleroma - o mundo material.

O Demiurgo fez o ser humano do lodo, a partir da substância invisível, matéria inconsciente e fluida, e soprou nele o psíquico. Por isso, segundo os valentinianos, o homem era qualificado nas Escrituras como imagem e semelhança de Deus, imagem na perspectiva hílica e semelhança na questão psíquica.

Todavia, Acamot semeou no Demiurgo, secretamente, a semente pneumática, a fim de que alguns seres fossem diferenciados. Sendo assim, o gnóstico era reconhecido como aquele "que recebeu a alma do Demiurgo, o corpo do lodo, a carne da matéria e o homem pneumático da Acamot"303.

Finalizando a descrição do sistema valentiniano ${ }^{304}$, Irineu afirma que o fim dos tempos configurava o momento em que os pneumáticos (gnósticos) fossem iniciados na gnose, conhecendo perfeitamente Deus e os mistérios de Acamot. Os hílicos seriam consumidos pelo fogo latente do mundo; os psíquicos, que estavam na Igreja, eram os cristãos que, por sua conduta irrepreensível, adentrariam definitivamente no Intermédio, lugar no qual, juntamente com o Demiurgo,

\footnotetext{
${ }^{301}$ IRINEU de Lião, Adversus haereses I, 4, 2.

${ }^{302}$ IRINEU de Lião, Adversus haereses I, 5, 1.

${ }^{303}$ IRINEU de Lião, Adversus haereses I, 5, 6.

${ }^{304}$ IRINEU de Lião, Adversus haereses I, 6,1-7,5.
} 
descansariam em paz eternamente. Portanto, a salvação dos pneumáticos não se dava pelas obras, mas pela predestinação à salvação, em virtude da gnose que neles fora semeada, sem algo que os levasse à corrupção.

No fim dos tempos, a Entímese seria reintroduzida no Pleroma e haveria de ser unida ao Salvador. Enquanto isso, os pneumáticos haveriam de se tornar espíritos intelectuais e teriam anjos para desposar.

Nos parágrafos onze e doze do livro I, Irineu listou, de forma resumida, variantes das doutrinas do sistema fundamental gnóstico, de modo que tratou de Valentim, de Secundo, dois grupos anônimos, e da escola de Ptolomeu, ou seja, considerando que todos esses grupos fossem oriundos da escola valentiniana ${ }^{305}$. Em cada grupo apresentado, surgiram pequenas peculiaridades doutrinais.

No sistema de Valentim ${ }^{306}$, existia uma Díada Inefável - Indizível e Silêncio -, da qual foi projetada uma segunda Díada - Pai e verdade. Desta Tétrada surgiram duas outras Díadas, formando a Ogdôada. Uma deu origem a dez éons e outra a doze éons. Um destes decaiu e formou o restante do universo.

Há dois Limites, um entre o Indizível e o Pleroma e outro, entre o Pleroma e o éon decaído, mãe do universo. O Cristo foi gerado pela mãe fora do Pleroma, segundo os moldes desses éons. Por isso, logo que conseguiu, entrou no Pleroma e abandonou a mãe. Dessa forma, ela criou o Demiurgo, senhor do universo.

Secundo ${ }^{307}$ dividiu a Ogdôada em direita e esquerda, luz e escuridão. Um anônimo $^{308}$ afirmava a existência de um Protoprincípio unicidade e de uma outra potência Unidade, que juntos emitiram a Mônada, princípio inteligente, ingênito e invisível, junto da qual estava o Um. As quatro potências emitiram os outros éons. Outro anônimo $^{309}$ explanou que a Ogdôada, primeira e primitiva, vinha antes da Profundeza e do Silêncio, e admitia existir a sizígia entre éons, mas estes seriam hermafroditas ou assexuados. E sobre a escola de Ptolomeu ${ }^{310}$, Irineu resumiu o modelo já apresentado acima.

\footnotetext{
${ }^{305}$ LAYTON, B., As escrituras gnósticas, p. 317-324.

${ }^{306}$ IRINEU de Lião, Adversus haereses I, 11, 1.

${ }^{307}$ IRINEU de Lião, Adversus haereses I, 11, 2.

${ }^{308}$ IRINEU de Lião, Adversus haereses I, 11, 3.

${ }^{309}$ IRINEU de Lião, Adversus haereses I, 11, 5.

${ }^{310}$ IRINEU de Lião, Adversus haereses I, 12, 1-4.
} 


\subsection{2.}

\section{A estrutura hierárquica do Pleroma: superioridade e inferioridade}

O mundo espiritual valentiniano, de forma generalizada, compõe-se de emissões que são fruto da sizígia entre dois éons, masculino e feminino, que, num processo de geração, vão constituindo a estrutura do Pleroma ${ }^{311}$.

A perspectiva de inferioridade e superioridade é estudada nesta pesquisa, pois a hierarquia espiritual está muito presente em diversos grupos religiosos anteriores e contemporâneos ao surgimento do cristianismo, e os gnósticos que se desenvolveram no seio da comunidade primitiva, com suas teorias, podem ter influenciado o surgimento dessa perspectiva hierárquica na eclesiologia dos primeiros séculos.

É possível compreender que essas emissões para composição da Tétrada, Ogdôada, Década e Duodécada se estruturam numa perspectiva hierárquica, não segundo o poder temporal, mas segundo a divisão das forças. Ou seja, quanto mais longe o éon estiver do Absoluto, menos força possui. Da mesma forma, os que estão na terra e possuem a faísca da gnose precisam tomar consciência desta constituição pneumática e evoluir num processo contínuo de gnose, para retornarem ao Pleroma.

No Sistema Fundamental descrito por Irineu, e apresentado acima, a Mônada existente desde sempre são formadas pelo Silêncio e pela Graça, e estão no nível espiritual mais elevado de abstração, acima de todos os pensamentos e interpretações. Por isso, são caracterizadas pela titulação negativa incompreensível, inatingível, invisível, inominável, ingênito -, visto que é impossível nomear de maneira positiva aquilo que está acima de toda afirmação.

No mito gnóstico clássico, como também nessa descrição irineovalentiniana, as emanações surgem do ato de pensar e, de modo especial, nessa primeira emanação - Mente e Verdade -, o objetivo é gerar a "plenitude", a "totalidade", o que Irineu nomeia de "um Princípio de todas as coisas".

Consequentemente, é formada a Tétrada primeva, que o pitagorismo entende como sentido fundante no número quatro, pois compreende os primeiros

${ }^{311}$ IRINEU de Lião, Adversus haereses I, 1, 1-3. 
números inteiros, cuja soma resulta em dez e também constitui o triângulo equilátero, ganhando assim o título de raiz da totalidade ${ }^{312}$.

Para mais, a importância da Tétrada se verifica no fato da Mente e da Verdade originarem todas as coisas, já que a Mônada é inacessível. A partir deste momento, as emanações surgem diretamente delas ou por sucessão. Por este motivo, Irineu nomeia a Mente também de Pai, Unigênito, Princípio de todas as coisas.

Tanto na descrição gnóstica, como na do bispo de Lião esta emanação tem características afirmativas e assume diretamente a responsabilidade de gerenciar e de dar forma a todo mundo espiritual, que não somente recebe a função geradora do Pleroma, mas também, diante do desequilíbrio, atua diretamente para restabelecer a estabilidade da realidade ${ }^{313}$. Essa Tétrada comporta o princípio inacessível e o princípio de todas as coisas.

A Ogdôada valentiniana nasce da iniciativa da Mente, que, tendo aprendido como a emanação acontece, semeando na verdade por conjugação e fazendo surgir o Verbo (logos) e Vida (zoé), "o Pai de todos os que viriam após Ele, Princípio e formação de todo o Pleroma" ${ }^{, 314}$. Este, por sua vez, faz emanar o Homem (anthropós) e a Igreja (ekklesía), formando com estes oito éons - que foram emanados dos mais perfeitos para os de menor perfeição - a Ogdôada primordial, raiz fontal da totalidade expressa pelo número oito, que, além de se destacar dentro do sistema da filosofia pitagórica, será exposto por Marcos, quando trata sobre o sentido deste número.

Ademais, os quatro pares primevos representam os quatro elementos clássicos de composição da matéria - fogo, água, terra e ar. Em vista disso, a Ogdôada é nomeada por Irineu como "raiz e substância de todas as coisas". O processo de emanação na Ogdôada mostra não só uma estrutura hierárquica já presente no mundo espiritual, como também uma distribuição de força ou capacidade a cada éon que diminui conforme se afasta do princípio originante e original.

A partir da Ogdôada, originam-se duas novas realidades no Pleroma valentiniano: a Década e a Duodécada. Porém, se a Ogdôada foi emitida para

\footnotetext{
${ }^{312}$ LAYTON, B., As escrituras gnósticas, p. 332; CONSENTINO, A., Contro le eresie/1, p. 68-69.

${ }^{313}$ CHIAPPARINI, G., Valentino gnóstico e platônico, p. 67.

${ }^{314}$ IRINEU de Lião, Adversus haereses I, 1, 1.
} 
glorificar o Abismo, o que procede dessa emissão - emanação como graça e louvor ao que emanou - é uma hierarquia de força e de honra.

Dessa forma, a Década e Duodécada continuam esse processo de glorificação dos éons superiores. Do Verbo e da Vida será emitida por conjugação a Década. Ora, o número dez tem um valor importante na compreensão pitagórica, mas aqui a Década tem um sentido que ultrapassa a concepção filosófica, uma vez que a sua emanação, em primeiro lugar, não se desenvolve como as anteriores (Ogdôada), pois as cinco conjugações são emanadas do Verbo e da Vida de forma igual, sem diferenciação ou degradação. E, no texto grego, os pares conservam o gênero masculino e feminino, mas os nomes não apresentam nenhum significado importante para a descrição de Irineu, segundo a qual aqueles devem ter origem em algum culto mistérico ou esotérico.

Para além do significado judaico do número dez na interpretação de $\operatorname{Marcos}^{315}$, ao nome de Jesus, que começa com a letra grega iota, é atribuído o valor dez no sistema numérico-alfabético ${ }^{316}$; do Verbo (palavra, logos) e da Vida originou a Década que representa o próprio Jesus.

Do Homem e da Igreja, que foram emanados do Verbo e da Vida, surgiu a Duodécada. Além de todo simbolismo próprio do número doze presente nas Escrituras, nessas emanações, a última - trigésima - será reconhecida como a décima segunda, a Sabedoria. Assim, o número doze será sinal da degradação, pois foi o éon feminino mais jovem que originou todo o desequilíbrio no Pleroma e, assim, surgiram o Demiurgo e a matéria.

Na sequência, Irineu afirma que "segundo eles, este é o Pleroma invisível e espiritual, com a sua tríplice divisão em Ogdôada, Década e Duodécada"317. O Pleroma, então, é composto por estes trintas éons, num processo de degradação nas emissões, e dividido em duas partes: a Ogdôada, a Década e a Duodécada ${ }^{318}$. Todas se tratam de seres espirituais, pensamentos e abstrações; nada construído na matéria.

\footnotetext{
315 IRINEU de Lião, Adversus haereses I, 18, 3.

${ }^{316}$ DONADON, D., Adversus haereses, p. 37-38.

${ }^{317}$ IRINEU de Lião, Adversus haereses I, 1, 3.

318 LAYTON, B., As escrituras gnósticas, p. 334; CHIAPPARINI, G., Valentino gnóstico e platônico, p. 72-74.
} 
A paixão da Sofia, descrita por Irineu ${ }^{319}$, representa um desequilíbrio no mundo espiritual, pois os éons deveriam se manter estáveis e equilibrados, mas a paixão que envolveu a Sofia se originou do amor do Unigênito pelo Abismo, que se depositou naquele último e mais novo éon.

O Intelecto era o único ser espiritual que tinha acesso livre e conhecia o Abismo. Sendo assim, essa "paixão", descrita por Irineu, pode não ser negativa, mas sim positiva, pela sua adoração ao Abismo ${ }^{320}$.

Ora, Irineu descreve a Sofia como o éon mais novo e último. Possivelmente, no processo de emanação em que se torna a última, constituída por um vestígio da estrutura hierárquica do Pleroma. Em contrapartida, Irineu afirma que Sofia tenta chegar ao Abismo, "lançando-se sempre para a frente", demonstrando novamente uma perspectiva hierárquica no Pleroma. Além disso, o bispo de Lião ainda afirma que se Sofia conseguisse chegar, "seria finalmente absorvida pela doçura do Pai e dissolvida na substância universal”,321, isto é, a Tétrada primeva lhe era tão superior, que haveria de absorvê-la totalmente, mostrando assim a diversidade de forças entre os éons hierarquicamente organizados ${ }^{322}$.

Indiretamente, três elementos novos são descritos no Pleroma valentiniano: Limite, Cristo e Espírito Santo. O Limite assume a missão de delimitar o mundo espiritual e ordenar tudo no seu lugar original. A Entímese, massa amorfa jogada no vazio, foi separada da Sofia depois que recobrou o seu estado original e retornou ao seu décimo segundo lugar. É a partir da Entímese que surgirá a matéria e o mundo material.

Além do mais, "o Unigênito, pela vontade do Pai, emitiu outro par, a fim de que nenhum outro éon sofresse a mesma paixão: estes são o Cristo e o Espírito Santo" ${ }^{323}$.

O Cristo ensinou aos éons a natureza da sizígia e os tornou capazes e idôneos para conhecerem e entenderem o Ingênito; em seguida, proclamou no meio deles o conhecimento do Protopai, que é incompreensível e inatingível, que ninguém pode ver nem entender a não ser por meio do Unigênito. "O Espírito ensinou a todos do mesmo modo a dar graças e introduziu-os no verdadeiro

\footnotetext{
${ }^{319}$ IRINEU de Lião, Adversus haereses I, 2, 2-3.

${ }^{320}$ CHIAPPARINI, G., Valentino gnóstico e platônico, p. 79.

${ }^{321}$ IRINEU de Lião, Adversus haereses I, 2, 2.

322 CHIAPPARINI, G., Valentino gnostico e platonico, p. 80-81; ROUSSEAU, A.; DOUTRELEAU, L., Contre lês hérésies livre 1, p. 176.

${ }^{323}$ IRINEU de Lião, Adversus haereses I, 2, 5.
} 
repouso. Estabilizados e gozando de repouso perfeito, os éons cantaram com grande alegria um hino ao Protopai, comunicador da grande alegria" ${ }^{324}$.

O Cristo, Éon masculino, revela todo o conhecimento a respeito do Abismo; o Espírito, Éon feminino, ensina o louvor e traz a estabilidade ao Pleroma, pois torna completamente iguais na forma de pensamento, eliminando todo interesse de avançarem na direção do Abismo ${ }^{325}$.

O desconhecimento e a desigualdade entre os entes espirituais geram o desequilíbrio no Pleroma, enquanto o Cristo e o Espírito são as emanações que possibilitam o retorno ao equilíbrio, não pela força, mas pelo conhecimento. A partir daí se obtém novamente a estabilidade do mundo espiritual, onde todos os éons, com a autorização do Cristo e do Espírito, homenageiam o Protopai origem de tudo -, emitindo, sem sizígia, como um Éon perfeito ou como uma estrela do Pleroma, chamada de Jesus. Este também é conhecido como Salvador, Cristo e Logos. Os éons, ao emanarem essa homenagem ao Abismo, oferecem o que têm de melhor. Sendo assim, Jesus é o suprassumo dos seres emanados no Pleroma.

A constituição do Pleroma narrado por Irineu e atribuído a Ptolomeu se organiza da forma explicitada. Porém, o bispo de Lião ainda descreve outras cosmologias gnósticas, como a doutrina ensinada por Marcos, o mago ${ }^{326}$, entre outras descrições menores e mais sintéticas.

Desse modo, fica claro que a Mônada primeira e inacessível, juntamente com a Tétrada representam os níveis mais elevados na hierarquia, pois concentram tanto a força espiritual quanto o poder de fazer emanar o Pleroma.

Na segunda Tétrada, formada pelos pares Verbo e Vida, Homem e Igreja, surge uma separação entre o que será emanado posteriormente, que depois se confirma pelo surgimento do Limite, que separa o mundo espiritual e o vazio, limitando o acesso dos outros éons à Tétrada primeva. Mesmo que as conjugações que compõem a Década e a Duodécada sejam emanadas de uma mesma fonte - a primeira do Verbo e da Vida, e a segunda do Homem e da Igreja -, essas não participam das mesmas realidades emanadas anteriormente, revelando uma limitação dentro do Pleroma.

\footnotetext{
${ }^{324}$ IRINEU de Lião, Adversus haereses I, 2, 6.

325 CHIAPPARINI, G., Valentino gnóstico e platônico, p. 99-100.

${ }^{326}$ IRINEU de Lião, Adversus haereses I, 14, 1-17, 2.
} 
Por mais que a gnose cristã valentiniana não seja reconhecida pelo fato de conter um processo de crescimento espiritual - como, por exemplo, entre os Zostrianos $^{327}$, que organizam seu sistema espiritual e terrestre claramente numa perspectiva de procedência por degradação, de modo que para atingir a gnose seja necessário o processo inverso -, torna-se clara a presença de um processo de degeneração nas emanações. Tanto é assim, que o Cristo e o Espírito vão aparecer para reequilibrar esse processo.

Não é possível compreender o sistema gnóstico fora de um contexto eclesiológico bem definito que se imponha, pelo menos, em função do processo de busca pela identidade cristã, que está se emancipando do judaísmo. Nesse sentido, qualquer que fosse a regra que os gnósticos encontravam para promover o seu tipo de afiliação, segundo as diversas e multifacetárias formas de agregação, certamente se adaptaria aos termos explícitos, que encontramos no sistema gnóstico.

Por isso, o termo Igreja, a hierarquia dos éons e a própria gnose como produto doutrinal de conhecimento designam, quer dependendo do cristianismo, quer fazendo com que o cristianismo dependa dela, os mais antigos conceitos ligados à eclesiologia desse grupo.

Quando esse cristianismo asiático-romano sai do judaísmo e se encontra com o gnosticismo, o termo Igreja está presente no gnosticismo e no cristianismo; a agregação de pertença está presente, como uma hierarquia de valores.

\section{2.}

\section{A ortodoxia de Irineu como chave de eclesiologia}

\subsection{1.}

\section{Os escritos de Irineu de Lião}

A principal obra de Irineu de Lião ${ }^{328}$, na sua dedicação em combater de modo especial as diversas teorias gnósticas e demais controvérsias da sua época, foi a Denúncia e refutação da falsa gnose, mais conhecida como Adversus haereses (Contra as heresias). O texto original contém cinco livros escritos em grego, depois do ano de 180 d.C., sendo os três primeiros no período de Eleutério

\footnotetext{
${ }^{327}$ LAYTON, B., As escrituras gnósticas, p. 145-167.

${ }^{328}$ PIACENTE, L., O encontro do cristianismo com a cultura clássica, p. 98-105.
} 
(175-189) e os outros dois livros no período de Vítor (189-198), ambos bispos de Roma. O texto original se perdeu, mas uma versão latina da obra, traduzida por volta do século III ou IV chegou aos nossos tempos, além de muitos trechos e até livros completos em textos de outros autores patrísticos ${ }^{329}$.

A obra foi endereçada a um "caríssimo amigo" 330 , que por diversas vezes foi citado no decorrer das argumentações, mas Irineu não apresentou nem o nome e muito menos a localidade deste destinatário. Embora durante o desenvolvimento dos cinco livros Irineu tenha sempre se dirigido a tal amigo como uma pessoa bem definida, Irineu revela um sentimento explícito de querer que o seu texto seja transmitido e ensinado a outras pessoas, como fica claro no prefácio do quinto livro:

anuímos ao teu pedido, porque somos encarregados do ministério da Palavra e nos esforçamos de todas as formas, segundo a nossa capacidade, por apresentar-te o maior número possível de subsídios para contrabater os hereges, converter os que se afastaram e reconduzi-los à Igreja de Deus e, ao mesmo tempo, confirmar os neófitos para que se mantenham firmes na fé que receberam intacta da Igreja, para que de forma nenhuma se deixem corromper pelos que tentam ensinar-lhes o erro e afastá-los da verdade ${ }^{331}$.

Este trecho ressaltou o caráter prático da obra, ou seja, Irineu a escreveu em virtude dos ensinamentos (gnosis) de Valentim e dos seus discípulos, além das atuações de Marcos, o mago, e seus seguidores, que estavam se espalhando dentro das comunidades cristãs. Por isso, “o caráter prático é o objetivo desta obra: defender o depositum fidei contra os heréticos (sobretudo os gnósticos), e expor com clareza aos fiéis o "cânon imutável da verdade"”332.

A obra Adversus haereses foi dividida por Irineu em cinco livros, mas isto não fez com que Irineu garantisse um desenvolvimento e uma exposição concatenada entre os livros. Ao contrário, o texto é cansativo pelas diversas repetições e digressões do autor, sem contar o seu caráter prolixo. "Santo Irineu não foi especulativo, nem erudito, nem homem de ciências; era homem de fé e da Igreja, bispo e, em sentido largo, vir apostolico, isto é, que viveu no e do ambiente apostólico" ${ }^{\text {333. }}$.

\footnotetext{
${ }^{329}$ MORESCHINI, C.; NORELLI, E., História da literatura cristã antiga I, p. 311; QUASTEN, J., Patrología I, p. 288-289.

${ }^{330}$ IRINEU de Lião, Adversus haereses I, prefácio 2.

${ }^{331}$ IRINEU de Lião, Adversus haereses V, prefácio.

${ }^{332}$ RIBEIRO, H., Contra as heresias, p. 11-12.

${ }^{333}$ RIBEIRO, H., Contra as heresias, p. 11-12.
} 
A. Orbe justificou os defeitos da escrita de Irineu de Lião dizendo que "o autor escreveu a obra de maneira intermitente. Não teve a habilidade de organizar os materiais de que dispunha de um modo homogêneo. Os defeitos de forma que atrapalham o leitor são provenientes da falta de síntese" ${ }^{\text {,34 }}$. Mas o próprio bispo de Lião argumentou que seu objetivo não foi uma escrita elaborada:

não procures em nós, que vivemos entre os celtas, e que na maior parte do tempo usamos uma língua bárbara, nem a arte da palavra, que nunca aprendemos, nem a habilidade do escritor em que nunca nos exercitamos, nem a elegância da expressão, nem a arte de convencer, que desconhecemos. Mas, na verdade, na simplicidade e na candura, aceitarás com amor o que com amor foi escrito e desenvolvê-lo-ás por tua conta, visto que és muito mais capaz do que nós ${ }^{335}$.

Desta forma, "Irineu sabe fazer uma descrição clara, simples e persuasiva da doutrina da Igreja" ${ }^{336}$, atingindo o seu objetivo com a obra Adversus haereses, que pretendeu colocar às claras (elenkhos) os ensinamentos que os gnósticos apresentavam secretamente aos seus seguidores e confrontá-los (anatrope) com a verdadeira interpretação das Escrituras e da doutrina cristã, pela regula veritatis $^{337}$.

Ademais, negou radicalmente o direito que os gnósticos se deram de dizer que seus ensinamentos eram gnosis, justificando que o conhecimento verdadeiro e único provém de Cristo e foi comunicado pelos apóstolos. Sendo este o único conhecimento verdadeiro e completo sobre a fé, e para que todos pudessem conhecê-lo, foram escritos os livros do Novo Testamento. Assim, o conhecimento escondido, destinado a alguns poucos predestinados, ou inspirado por uma pessoa, que se autoafirmasse para além da Revelação feita por Jesus Cristo, era taxado como controverso e servia como indicativo dos ensinamentos que deviam ser excluídos daqueles convencionados pelo cristianismo nascente ${ }^{338}$.

No prólogo da coletânea das obras de Irineu de Lião, organizado por Floro bispo de Lião em 860 -, é possível entender a singularidade e importância que teve a Adversus haereses no tempo em que fora escrita. Escreve o bispo:

Existem cinco razões, que a nosso modo de ver, evidenciam não ser supérflua a estafante atividade de transcrever este livro. Primeira, porque é raríssimo, pois caído o silêncio sobre as heresias, destruídas em nossos dias com insólita violência, quase ninguém mais se anima a manuseá-lo. Segunda, que o autor é antigo, próximo aos tempos apostólicos e por isso é digno de fé. Terceira, que tudo o que

\footnotetext{
${ }^{334}$ ORBE, A., Espiritualidad de San Ireneo, p. 5.

335 IRINEU de Lião, Adversus haereses I, prefácio 3.

${ }^{336}$ ORBE, A., Espiritualidad de San Ireneo, p. 5.

${ }^{337}$ MORESCHINI, C.; NORELLI, E., História da literatura cristã antiga, p. 311.

${ }^{338}$ DROBNER, H., Manual de Patrologia, p. 148-149.
} 
escreveu a propósito dos heréticos não recolheu só por ouvir dizer ou por fama, mas ouviu ensinar em grande parte pela viva voz de tais mestres e com os próprios olhos viu praticar, pois lhes era coevo, ou seja, contemporâneo e natural daqueles lugares. Quarta, acerca das heresias daquele tempo, nenhum outro discutiu com maior profundidade e clareza. Quinta, é necessário sobretudo restabelecer a ciência das armas da Igreja militante - descuidadas em tempos de paz - porque diminuindo os defensores a tirania vai se enfurecendo tanto mais agudamente quanto é livre em fazê-lo impunemente ${ }^{339}$.

Os cinco livros da Adversus haereses formam duas grandes partes, como estabeleceu o título da obra "Denúncia e Refutação". O primeiro livro tem como objetivo principal mostrar, "com poucas e claras palavras, a doutrina dos que, neste momento, ensinam de maneira diferente da nossa; quero dizer de Ptolomeu e dos que lhe estão à volta, cuja doutrina é como que a flor da escola de Valentim" 340 .

O objetivo fundamental para Irineu foi desvelar os conhecimentos que os gnósticos mantinham em segredo aos membros das escolas e aos discípulos ou escolhidos para a iluminação (gnosis), como explica neste breve trecho: "que nos urge a manifestar a ti e a todos os que estão contigo os ensinamentos deles, que foram conservados secretos, e que agora, pela graça de Deus, se tornam manifestos"341.

De modo geral, o livro I tratou de uma ampla exposição do sistema gnóstico de Ptolomeu [1,1-8,4], discípulo de Valentim, como uma base comum de pensamento para todos os diversos grupos, finalizando com uma exegese valentiniana do prólogo do Evangelho de João. Esta descrição foi seguida de uma primeira refutação [9,1-5], na qual Irineu apresentou regula fidei da igreja de Lião, trazendo os elementos básicos do símbolo dos apóstolos. O autor continuou descrevendo, breve e pontualmente, as características próprias [11,1-12,4] de algumas escolas gnósticas, todas com forte influência da doutrina valentiniana.

As liturgias mágicas e as doutrinas de Marcos, o mago [13,1-22,2], ganharam destaque na descrição de Irineu, que também associou os cultos mistéricos e mágicos com o conjunto dos gnósticos. Finalizou o livro I com uma grande descrição da genealogia [23,1-31,1] da gnose, partindo de Simão, o mago, como princípio do surgimento dos gnósticos no meio cristão - criticado pelos próprios apóstolos, pois desejava comprar a graça do Espírito Santo (At 8,9-24) -,

\footnotetext{
${ }^{339}$ RIBEIRO, H., Contra as heresias, p. 9.

${ }^{340}$ IRINEU de Lião, Adversus haereses I, prefácio 2.

${ }^{341}$ IRINEU de Lião, Adversus haereses I, prefácio 2.
} 
passando por outros grupos e doutrinas gnósticas diversas. Concluiu [31,2-4] retomando o objetivo principal, ou seja, reforçou como foi importante a demonstração das teses gnósticas, para que, vindo às claras as gnoses escondidas em mistérios e as construções falaciosas, pudessem ser combatidas.

A segunda parte, ou seja, a Refutação da falsa gnose, Irineu dividiu nos quatro livros seguintes, apresentando os argumentos necessários para contrapor os ensinamentos gnósticos. No livro II, o autor utilizou os argumentos da razão para se opor especificamente à doutrina dos valentinianos e dos marcionitas, para daí atingir a todos os gnósticos. Em primeiro lugar [1-11], Irineu refutou a doutrina do Pleroma superior ao Deus Criador, justificando que, se isto realmente existisse, o monoteísmo cristão e o conceito de Deus seriam esvaziados, pois o demiurgo gnóstico era um deus limitado e jamais poderia ser o Deus de Jesus Cristo. Na sequência, fez algumas exposições contrárias à doutrina dos éons ou hipóstases divinas [12-19], à numerologia valentiniana [20-28] e à escatologia gnóstica [2930]. O livro segundo foi finalizado [31-35] com refutações às diversas teses gnósticas específicas, como as práticas mágicas de Carpócrates e Simão, os 365 céus de Basílides e a doutrina da metempsicose.

O terceiro livro se destina, nas palavras do próprio autor, a apresentar as provas bíblicas que sirvam para "refutar todos os que de qualquer forma ensinam a mentira" ${ }^{342}$. Para o bispo de Lião, a autoridade e a verdade presentes nas Sagradas Escrituras estavam baseadas na legitimidade do ensinamento apostólico nelas contido e também na Tradição da Igreja, que por meio da Sucessão Apostólica remontava diretamente a Cristo Jesus, diferentemente dos gnósticos, que se baseavam nos fundadores das escolas [1-5].

Depois desta fundamentação apostólica, Irineu apresentou duas refutações contra teorias gnósticas: primeiro [6-15] argumentou sobre a unicidade criadora de Deus no conjunto das Escrituras, mostrando as passagens que na Septuaginta e nos textos neotestamentários se referiam ao Deus Uno. Tratou de Jesus Cristo, na segunda refutação [16-23], mostrando, de modo especial contra os ebionitas, que o Cristo e Jesus eram uma só e única pessoa.

Nesse momento, foi apresentada a doutrina da recapitulação ${ }^{343}$ (anakefalaíosis), própria do bispo de Lião, que afirmou que Cristo era o novo

${ }^{342}$ IRINEU de Lião, Adversus haereses III, prefácio.

${ }^{343}$ SESBOÜÉ, B., Tout récapituler dans le Christ, p. 130-163. 
Adão, e que o pecado de Adão tinha arruinado e desordenado todo sistema harmônico criado por Deus desde o princípio de tudo. Sendo assim, a encarnação de Jesus Cristo teve o poder de recapitular - compendiar, concentrar - na sua pessoa todas as criaturas, comunicando-lhes a imortalidade e a incorruptibilidade. Dessa forma, harmonizou o universo, que teria o seu ocaso quando, pela ressurreição de Jesus Cristo e o estabelecimento do seu Reino definitivo, todos fossem um só em Cristo Jesus. Com uma invocação a Deus [24-25] pela conversão dos hereges, Irineu finalizou o terceiro livro mostrando o seu objetivo fundamental como bispo, não só demonstrar e refutar as teses gnósticas, mas trazer de volta ao rebanho as ovelhas extraviadas ${ }^{344}$ :

quanto a nós, rezamos para que não permaneçam na fossa que cavaram para si mesmos, se separem de tal Mãe [Acamot], saiam do Abismo, se afastem do vazio, abandonem as trevas, sejam gerados como filhos legítimos, convertendo-se à Igreja de Deus, o Cristo seja formado neles, conheçam o Criador e o Autor deste universo como único verdadeiro Deus, Senhor de todas as coisas. Esta é a nossa oração para eles e com isso amamos realmente muito mais do que eles julgam amar a si mesmos. (...) não nos cansamos e continuaremos a estender-lhes as mãos ${ }^{345}$.

Uma doutrina importante sistematizada por Irineu de Lião neste livro III foi a definição de regula fidei - regula veritatis ou depositum fidei - como cânone imutável da verdade, que foi a mensagem transmitida pelos apóstolos e conservada pela Igreja: pela Sucessão Apostólica, pela assistência do Espírito de Deus vivente e operante, e pelo batismo. Além disso, apresentou Maria como a Mãe do Redentor, num paralelo com a doutrina paulina de Adão-Cristo, apresentando Maria como a nova $\mathrm{Eva}^{346}$.

No quarto livro, Irineu refutou os gnósticos, demonstrando a harmonia entre os dois testamentos que formam as Escrituras e a identidade de Deus e do Criador. Partindo das Palavras de Jesus [1-19], Irineu expôs que o Filho reconheceu o Pai como Criador e autor da Lei, evidenciando que um só era o Deus de onde provinha tudo. Expôs, ainda, que nos Evangelhos se evidenciou o cumprimento da Lei, para chamar os judeus à obediência. E o grande sinal desta Nova Aliança era a Eucaristia, entendida como oferta e sacrifício. Nos parágrafos 20-35, Irineu discorreu sobre a profecia no Antigo Testamento, sobre o seu valor, seu sentido e o cumprimento de tudo por meio de Jesus Cristo.

${ }^{344}$ MORESCHINI, C.; NORELLI, E., História da literatura cristã antiga, p. 312-313; LOPES, G., Patrística pré-nicena, p. 156-157.

${ }_{345}$ IRINEU de Lião, Adversus haereses III, 25, 7.

${ }^{346}$ LOPES, G., Patrística pré-nicena, p. 156-157. 
De modo especial, refutou os marcionitas, que defendiam a inferioridade do Deus de Israel, por meio da exegese de textos veterotestamentários. Finalizou o livro IV [36-41] explicando, a partir de um estudo das parábolas de Jesus, contidas nos Evangelhos, a unidade de Deus ${ }^{347}$. Isso porque a interpretação alegórica dos gnósticos, em torno das parábolas, escondia ou até distorcia o verdadeiro sentido da Escritura. Portanto, Irineu mostrou que "o caminho para chegar a Deus aponta para a exegese das parábolas"348. Os Padres da Igreja dos séculos II e III se debruçaram excessivamente sobre as parábolas neotestamentárias para se aprofundarem na descoberta de Deus ${ }^{349}$.

No quinto livro, Irineu continuou extraindo dos textos bíblicos as exposições e as refutações contra a pseudognose ${ }^{350}$. Ou seja, de tudo que foi refutado e argumentado no conjunto dos três livros anteriores - II, III, IV -, Irineu complementou essa confutação com temas específicos da teologia cristã.

Na primeira parte do livro V [1-14], o tema discutido foi a salvação da carne, negada pelas teorias gnósticas. O bispo de Lião afirmou que a encarnação de Cristo e a ressurreição da carne conferiram ao Deus dos cristãos um poder superior aos éons dos gnósticos, pois estes se baseavam apenas na carne e no sangue, e os cristãos eram cheios do Espírito. Para Irineu, "a carne é morta sem o Espírito inserido nela, que é o único capaz de vivificá-la, de modo que não é ela que herda o Reino, mas é antes possuída em hereditariedade; as obras da carne, contrárias ao Reino, são as cumpridas em ausência do Espírito"351.

Na segunda parte [15-24], o bispo de Lião retomou o tema da identidade criadora do Deus e Pai de Jesus Cristo, por meio de três relatos das Escrituras: o cego de nascença (Jo 9) que recuperou a vista pelas "mãos de Deus", as quais modelaram o ser humano, e, no sinal taumatúrgico, Jesus repetiu este gesto divino da criação; a crucifixão de Jesus, que curou a ferida da desobediência aberta por Adão; a fidelidade de Jesus à Lei e às Escrituras venceu o diabo no deserto e abriu ao ser humano o caminho fechado por Adão, que se deixou levar pelo erro.

A escatologia cristã ganhou destaque na terceira parte do livro [25-36], em que Irineu explanou, a partir da exegese de textos das Sagradas Escrituras, sobre o

\footnotetext{
${ }^{347}$ MORESCHINI, C.; NORELLI, E., História da literatura cristã antiga, p. 312-313.

${ }^{348}$ ORBE, A., Teologia de San Ireneo I, p. XIII.

${ }^{349}$ ORBE, A., Teologia de San Ireneo I, p. 27-34.

${ }^{350}$ IRINEU de Lião, Adversus haereses, V, prefácio.

${ }^{351}$ MORESCHINI, C.; NORELLI, E., História da literatura cristã antiga, p. 313.
} 
fim do mundo quando o diabo, que desejou ser adorado, seria vencido definitivamente e a Jerusalém celeste apareceria sobre todos os justos. Além disso, o Reino de Deus seria estabelecido com uma nova terra e todos poderiam conhecer a Deus de maneira sempre nova.

Neste quinto livro, também se tornou presente a visão milenarista ${ }^{352}$ comum aos Padres da Igreja dos primeiros séculos. Eles acreditavam que, depois do sexto milênio da criação, Jesus Cristo viria estabelecer o seu Reino na terra, onde os justos ressuscitados tomariam parte do Reino Triunfante por mil anos, até que chegasse o juízo universal e o Reino Eterno. Este entendimento milenarista foi combatido e refutado pela patrística dos séculos seguintes.

Outra obra de Irineu de Lião estudada nesta pesquisa foi a Epideixis, ou Demonstração da pregação apostólica, cuja primeira notícia existente sobre este texto é tirada de Eusébio de Cesareia, ao afirmar que: "além das supramencionadas obras de Irineu e de suas cartas, dele ainda possuímos: um livro dedicado a um irmão chamado Marciano, Demonstração da pregação

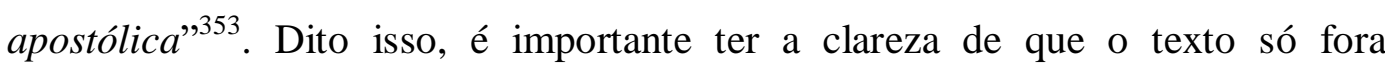
reencontrado em 1904, num manuscrito armênio, na igreja da Mãe de Deus de Erivan, no Azerbaijão, e publicado em 1907.

Nessa primeira edição, organizada por Adolfo Harnack, o texto foi dividido em cem parágrafos e conservado assim nas edições posteriores. A análise crítica da forma da escrita e da teologia presentes na obra tornou indubitável a autoria do texto: Irineu de Lião. Como na Epideixis, é citada por várias vezes a Adversus haereses. Então, seria possível datá-la entre 185 e 202, com alguns autores afirmando o ano de 190.

Irineu já é um ancião ao escrever a Epideixis e a envia a um amigo chamado Marciano. O objetivo é apresentado pelo próprio Irineu: “expor brevemente a pregação da verdade, para que te consolides na fé; uma série de anotações sobre pontos fundamentais do Corpo da verdade; e que tenhas à mão as provas das

\footnotetext{
${ }^{352}$ Milenarismo ou quiliasmo, em grego, é uma crença escatológica, presente nos primeiros séculos do cristianismo, que acredita na parusia ou segunda vinda de Jesus, e a partir dela a instauração de um Reino terrestre ou celeste, dependendo do autor. Nesse reino, os santos e mártires ressuscitariam e gozariam por mil anos. Depois, as forças de Satanás retornariam e seriam derrotadas por Jesus Cristo. Deste modo, seguiria o juízo final, a destruição do mundo e o início definitivo da Vida Eterna no paraíso. Para os movimentos milenaristas do cristianismo antigo, Deus ou Jesus Cristo seriam os protagonistas da instauração deste reino, anunciado pelos profetas e confirmado por Jesus (SOTOMAYOR, M.; UBIÑA,J., Historia del cristianismo, p. 229-232).

${ }^{353}$ EUSÉBIO de Cesareia, História Eclesiástica V, 26.
} 
realidades divinas" ${ }^{354}$. Sendo assim, o complemento que E. Peretto dá ao título da Epideixis torna-se não somente aceitável como significativo, antigo catecismo de adultos $^{355}$.

Uma das possíveis divisões da obra ${ }^{356}$ pode ser apresentada da forma que segue: Prólogo [1-3]; Ensinamento dos apóstolos [4-42]; Demonstração escriturística profética e pela pregação dos apóstolos [43-97]; Conclusão [98-100]. A. Benoit afirma que a diferença entre a Adversus haereses e a Epideixis é que a primeira tem o acento na teologia e a segunda enfatiza a cristologia e soteriologia $^{357}$.

No Prólogo [1-3], Irineu afirma a necessidade de apresentar a pregação apostólica como fundamento da salvação, caminho que conduz para a vida que está em Deus, que se dá pela regula fidei, vivida e celebrada. No Ensinamento dos apóstolos [4-42], inicia com a afirmação trinitária de Deus Pai, Criador do mundo e dos seres humanos, o qual, pelo Verbo e pelo Espírito, ordena todas as coisas, estabelecendo a comunhão entre Deus e homens com o novo nascimento que se dá no batismo.

A partir desse momento, apresenta a história da salvação narrada no Antigo Testamento, desde Adão até a Encarnação do Verbo de Deus, enfatizando que é no Cristo que o Pai recapitula toda esta história e salva. A Encarnação do Filho de Deus é então o início desse processo de recapitulação e é na carne humana, adentrando nela, que Deus resgata o ser humano decaído da incorruptibilidade.

Nos parágrafos 32-34, os paralelos entre Cristo e Adão, e entre Eva e Maria são os destaques apresentados por Irineu, pois a árvore da cruz vence sobre a árvore do bem e do mal. O bispo de Lião continua a exposição mostrando que em Cristo as promessas feitas a Abraão e a Davi obtêm pleno cumprimento.

$\mathrm{Na}$ terceira parte [43-97], Irineu apresenta as provas escriturísticas - Antigo e Novo Testamento - para autentificar suas afirmações cristológicas. O arcabouço escriturístico de Irineu é bastante amplo, com diversas interpretações. No final dessa parte [86-97], ele enfatiza sobre a perspectiva missionária da Igreja, tendo os apóstolos como grandes protagonistas e modelos na evangelização, tanto dos

\footnotetext{
${ }^{354}$ IRINEU de Lião, Epideixis 1.

${ }^{355}$ PERETTO, E., Epideixis, antico catechismo degli adulti, p. 25-32.

${ }^{356}$ POSE, E., Ireneo de Lión, p. 30-38; RIBEIRO, A., Demonstração da pregação apostólica, p. 35-38.

${ }^{357}$ BENOIT, A., Saint Irénée, p. 246-247.
} 
judeus como dos pagãos. Para estes, Irineu reforça, ainda, a ação misericordiosa de Deus, que deseja salvar a todos. Em contrapartida, faz uma crítica aos seguidores de Moisés, que abandonaram os pagãos à própria sorte e não cumpriram o chamado do Senhor.

A Igreja é, então, a grande responsável por reunir todos sob o primado do amor: gentios, judeus, cristãos.

Na última parte [98-100], Irineu reforça a importância de se afastar dos hereges e dos incrédulos e de buscar a verdade na pregação da Igreja, testemunhada pelos apóstolos. "Nota-se na exposição de Irineu o testemunho da presença do Verbo divino nas diversas etapas da história da salvação, especialmente no Antigo Testamento" ${ }^{\text {358. Ne }}$. Neste Verbo está a recapitulação da obra criadora do Senhor. Por isso, o bispo de Lião relaciona a presença redentora de Cristo com a pregação dos apóstolos e da Igreja, em todos os lugares.

\subsection{2.}

\section{A eclesiologia na Adversus haereses e na Epideixis}

Nesta etapa, temos o objetivo de analisar as obras de Irineu de Lião, Adversus haereses e Epideixis, tendo como parâmetro de pesquisa a compreensão do autor sobre a Igreja. No decorrer da pesquisa, tendo lido e analisado os textos, preferimos dividir a análise, didaticamente, em sete partes que se complementam e fundamentam a eclesiologia irineana: a Igreja e suas características; as referências ao batismo; a regula fidei; a atuação da Igreja; a Tradição apostólica; a sucessão apostólica e a Virgem Maria no mistério da recapitulação de Jesus Cristo. Em cada parte, o foco principal está na análise de trechos do pensamento do autor e na interpretação a partir de referências externas, mas também a partir do que é possível apreender do próprio autor. Como esta é a parte central da investigação da tese, torna-se necessário adentrar no pensamento e na compreensão do autor, a partir de trechos que selecionamos em uma leitura cautelosa, que nos possibilitasse organizar o pensamento eclesiológico de Irineu.

Nesta fase da pesquisa, já é possível confirmar que Irineu não nos tenha deixado um conteúdo sistematizado sobre a Igreja, visto que não era esse o método de expor as verdades cristãs nos apologistas do segundo século. Nem por

${ }^{358}$ RIBEIRO, A., Demonstração da pregação apostólica, p. 38. 
isso deixamos de encontrar explicações claras sobre a Igreja, sobretudo no que diz respeito ao desenvolvimento tão significativo para o fim do século II da era cristã. Irineu não é um pensador que analisa a Igreja de forma externa, mas tenta compreender a realidade Igreja na sua constituição como "assembleia de Deus".

Irineu é bispo em Lião e tem a consciência da sua missão para pastorear o rebanho que lhe fora confiado pelo Senhor, por meio da sucessão apostólica. Por isso, sua incansável insistência na explicação sobre os princípios da fé afirmada por Jesus Cristo, Filho de Deus, divulgada pelos apóstolos e testificada na regula fidei e no testemunho dos cristãos.

\subsubsection{1.}

\section{A Igreja e suas características}

A Igreja é obra de Deus, que, no mistério insondável do seu amor de Pai pelo ser humano criado, envia o Filho Jesus Cristo, para recapitular a criação, para resgatar o homem decaído e restituir-lhe a dignidade de filho por meio da adoção em Cristo. Enviando o Espírito, possibilita aos apóstolos e aos discípulos não só o dom de crer, mas também de anunciar essa Boa Nova da salvação, para instruir e fundar a Igreja ${ }^{359}$.

Ao afirmar isso, Irineu apresenta a Igreja entre a Encarnação do Filho de Deus e sua volta, no juízo final. Demonstra que a formação da Igreja é uma iniciativa divina, porém seu desenvolvimento está diretamente relacionado com a realidade humana, com a promessa feita a Abraão e seus filhos, pois é na realidade criada por Deus que ela se desenvolve, e nela concretiza-se o tempo da graça do Senhor, que é sempre o tempo presente, "em que são chamados os que creem nele e se tornam aceitos por Deus" ${ }^{\prime 60}$.

De fato, Irineu afirma que a Igreja é composta dos que receberam a adoção filial, de modo que são eles que "constituem a Igreja, que é a assembleia de Deus, que Deus, isto é, o Filho, reuniu Ele mesmo e por si mesmo" "361 . O fundamento da Igreja está em Cristo e no seu projeto de recapitular toda a criação em torno de Deus, o Criador.

\footnotetext{
${ }^{359}$ IRINEU de Lião, Epideixis 41.

${ }^{360}$ IRINEU de Lião, Adversus haereses II, 22, 2.

${ }^{361}$ IRINEU de Lião, Adversus haereses III, 6, 1.
} 
Desse modo, a Igreja, iniciada pelos apóstolos que acolheram o envio e a mensagem do Senhor, está espalhada por toda a terra. Ela persevera numa só e idêntica fé em Deus e no seu Filho ${ }^{362}$, e tem por fundamento e coluna o Evangelho e o Espírito da vida ${ }^{363}$, que a sustentam, tornando possível a continuação da obra divina.

Se, para os diversos grupos gnósticos, segundo D. Brakke, a verdadeira igreja é composta apenas por aqueles que possuem a faísca divina e que, ao serem despertados para a gnose, descobrem o conhecimento oculto sobre a sua pertença ao Pleroma ${ }^{364}$, para Irineu a comunhão com comunidade eclesial se dá na pertença a Cristo, na fé e na confiança na Boa Nova que Ele anunciou.

Depois de ter verificado os estatutos da regula veritatis do modo como the era possível, isto é, confirmando o ensinamento de Cristo e dos apóstolos, compreendeu que a Igreja não poderia ser destinada para os selecionados. Pelo contrário, a Igreja é uma obra destinada para os filhos e as filhas criados no amor de Deus, pelo Verbo e pelo Espírito; é a comunidade dos fiéis espalhada por todas as realidades do mundo, que, ao ouvir o chamado do Senhor, responde com decisão e compromisso ${ }^{365}$.

C. Granado afirma que a ação e a presença do Espírito de Deus constituem os fundamentos da vida eclesial ${ }^{366}$, já que, como afirma Irineu, “onde está a Igreja, aí está o Espírito de Deus, e onde está o Espírito de Deus ali está a Igreja e toda a

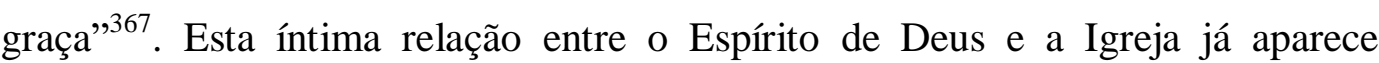
referendada no Antigo Testamento, mas é Lucas quem ressalta que o Espírito não só vem sobre os apóstolos e sobre os discípulos reunidos em Pentecostes, mas que também lhes concede o poder de inserir a presença de Deus na vida de todos os povos. "Eis por que, na harmonia de todas as línguas, cantavam hinos a Deus, enquanto o Espírito reunia na unidade as raças diferentes e oferecia ao Pai as primícias de todas as nações"368.

A Igreja constituída pelo Espírito Santo em Pentecostes assume a missão de ir pelo mundo todo levando o orvalho do Espírito, para que todos se tornem um só

\footnotetext{
${ }^{362}$ IRINEU de Lião, Adversus haereses III, 12, 7.

${ }^{363}$ IRINEU de Lião, Adversus haereses III, 11, 8.

${ }^{364}$ BRAKKE, D., Los gnósticos, p. 43-44.

${ }^{365}$ FANTINO, J., La théologie d'Irénée, p. 27-28; OSBORN, E., Irenaeus of Lyons, p. 146-148; GROSSI, V.; DI BERARDINO, A., La chiesa antica, p. 48-49.

${ }^{366}$ GRANADO, C., El Espiritu Santo em la teologia patrística, p. 41-43.

${ }^{367}$ IRINEU de Lião, Adversus haereses III, 24, 1.

${ }^{368}$ IRINEU de Lião, Adversus haereses III, 17, 2.
} 
em Cristo, pois sem a água que vem do céu, nem a farinha pode se tornar pão, nem os seres resgatados na recapitulação do Senhor podem se tornar filhos. "E assim como a terra seca não pode frutificar sem receber água, também nós, que éramos antes lenho seco, jamais daríamos frutos de vida sem a chuva generosa enviada do Alto"369.

Foi pelo banho do novo nascimento em Cristo que fomos unidos definitivamente ao Senhor pelo selo do Espírito Santo. Contudo, é preciso que sejamos frutíferos, cultivando uma boa relação entre os irmãos ${ }^{370}$. Foi sobre este mesmo Espírito que o Senhor disse aos seus discípulos, pedindo ao Pai que o enviasse sobre eles para que pudessem evangelizar os povos com eficácia e vencessem as armadilhas do inimigo. Ora, o demônio veio como um raio para fazer perder os filhos de Deus, mas a Igreja reza ao seu Senhor para que envie o Espírito da verdade ${ }^{371}$.

Outrossim, Irineu afirma que os que foram renovados pelo banho batismal precisam guardar fielmente o depositum fidei, que o Senhor concedeu à sua Igreja pela graça do Espírito Santo, a fim de renovar constantemente quem preserva a fé, já que "este dom de Deus foi confiado à Igreja, como o sopro de vida inspirado na obra modelada, para que sejam vivificados todos os membros que o recebem"372.

O Espírito da verdade, segundo Laiti, capacita a Igreja a entrar em comunhão com o seu Senhor, como verdadeiro Corpo de Cristo $^{373}$, que se alimenta dele ao mesmo tempo que alimenta os seus com a Palavra da verdade, pois sua vocação vem da novidade do Espírito e não da caducidade da letra, já que o Senhor afirma: "concluirei com a casa de Israel e com a casa de Judá uma Aliança nova. (...) Porei minhas leis no fundo de seu ser e a escreverei em seu coração. Então serei seu Deus, e eles serão o meu Povo"374.

De igual modo, a Igreja que alimenta os filhos e filhas de Deus é, também, uma mãe que se preocupa com quem se afasta do Corpo de Cristo, pois, dessa forma se afasta da verdade. Estes cavam para si "buracos na terra como cisternas

\footnotetext{
${ }^{369}$ IRINEU de Lião, Adversus haereses III, 17, 2.

${ }^{370}$ IRINEU de Lião, Adversus haereses III, 17, 2.

${ }^{371}$ IRINEU de Lião, Adversus haereses III, 17, 3.

372 IRINEU de Lião, Adversus haereses III, 24, 1; LAITI, G., La chiesa nell'economia di Dio secondo Ireneo di Lione, p. 172-173.

${ }^{373}$ LAITI, G., La chiesa nell'economia di Dio secondo Ireneo di Lione, p. 173-174.

${ }^{374}$ IRINEU de Lião, Epideixis 90.
} 
fendidas e bebem a água pútrida de lamaçal; fogem da Igreja por medo de serem desmascarados e rejeitam o Espírito para não serem instruídos"375.

Portanto, Irineu demonstra que os grupos gnósticos que se afastavam da Igreja, ao dizerem que nela não havia a verdade, não desejavam receber o Espírito Santo, nem queriam ser instruídos na verdade. Viviam de um conhecimento escondido a partir de fábulas construídas e elaboradas para confundir, ao invés de esclarecer. Já a Palavra de Deus é como uma luz que ilumina todas as partes. "Com efeito, em todo lugar, a Igreja prega a verdade, verdadeiro candelabro de sete braços, trazendo a Luz de Cristo",376.

A. Orbe afirma que Irineu, ao comparar a Igreja com o candelabro de sete braços, reafirma a sua missão de ser o sustentáculo da luz de Deus, que é o Cristo. Essa luz confiada à Igreja é a verdade que ela anuncia, a qual brotou da cruz do Cristo e se perpetua universalmente até sua vinda no final dos tempos ${ }^{377}$. G. Laiti também justifica que a chave eclesiológica apresentada pelo bispo de Lião reforça a missão própria da Igreja, pois os sete braços evocam os sete dons do Espírito (Is 11,2), que pousam sobre o Messias ${ }^{378}$. A Igreja reflete essa luz do Cristo por todo o mundo no seu anúncio, nunca perdendo a sua característica de discípula do único mestre e sempre propagando a Boa Nova em sua perspectiva missionária ${ }^{379}$.

A relação entre a promessa feita a Abraão, conforme J. Faus ${ }^{380}$, de constituílo como um grande povo, e a Igreja nascida da nova Aliança em Cristo é um dos fundamentos que definem a Igreja na obra de Irineu de Lião. Abraão é o iniciador, o patriarca que anuncia a fé no Deus vivo e em quem estão prefigurados os dois testamentos $^{381}$, tornando-se o pai "de todos os que seguem o Verbo de Deus e aceitam viver neste mundo como estrangeiros, isto é, de todos os fiéis que vêm da circuncisão e do paganismo"382. É então a partir dessa fé dúplice, segundo A. Orbe, que se edifica o templo do Senhor, que tem Cristo como a pedra fundamental. No Verbo de Deus, circuncisos e incircuncisos tornam-se seguidores

\footnotetext{
${ }^{375}$ IRINEU de Lião, Adversus haereses III, 24, 1.

${ }^{376}$ IRINEU de Lião, Adversus haereses V, 20, 1; LAITI, G., La chiesa nell'economia di Dio secondo Ireneo di Lione, p. 174-175.

377 ORBE, A., Teología de san Ireneo II, p. 317-319.

${ }^{378}$ IRINEU de Lião, Epideixis 59; 9.

${ }^{379}$ LAITI, G., La chiesa nell'economia di Dio secondo Ireneo di Lione, p. 174-175.

${ }^{380}$ FAUS, J., Carne de Dios, p. 179-180.

${ }^{381}$ IRINEU de Lião, Adversus haereses IV, 31, 2; IV, 32, 1.

${ }^{382}$ IRINEU de Lião, Adversus haereses IV, 25, 1; V, 25, 2; V, 32, 2.
} 
e membros de um único corpo ${ }^{383}$. Irineu aprofunda e exemplifica essa maneira dúplice de argumentar usando várias referências do Antigo Testamento (Gn 13,14-18; Gn 19,31-38; Gn 38,27-30).

Irineu também caracteriza o nascimento da Igreja a partir da descendência de Davi, presente na profecia de Isaías: "naquele dia, a raiz de Jessé, que se ergue como um sinal para os povos" (Is 11,10). Essa característica é clara, pois este "sinal para os povos" é o Cristo, e este descendente de Davi; depois de sua morte e ressurreição, estabeleceu a "tenda do seu corpo" sobre nós, ou seja, a Igreja. ${ }^{384}$.

O próprio Isaías, segundo a interpretação de Irineu, afirma que haverá um tempo para uma nova Aliança a ser concretizada com os gentios: "naquele dia, o homem atentará para o seu Criador e os seus olhos se voltarão para o Santo de Israel. Ele não tornará a atentar para os altares; ele não voltará a olhar para as estelas sagradas, nem para os altares de incenso" (Is 17,7).

Essa nova Aliança no Santo de Israel, o Cristo, é a Igreja ${ }^{385}$, que não se firma mais sobre a herança de Moisés, em função daqueles que "abandonaram o verdadeiro Deus, adoraram falsos deuses, mataram os profetas de Deus; desprezaram o verdadeiro Filho de Deus, escolhendo Barrabás; renegaram o Rei Eterno, reconhecendo César como rei" ${ }^{386}$. Logo, o Senhor decidiu dar sua herança aos gentios estultos e aos que não conheciam Deus. Assim, afirma Irineu, Deus comunica duas grandes promessas aos que decidem adentrar nessa nova Aliança: “ora, graças a esse chamado, foi-nos dada a vida, e Deus restaurou em nós a fé de Abraão [e] nós, de fato, acolhemos o Senhor da Lei, o Filho de Deus e, mediante a fé nele, aprendemos a 'amar a Deus com todo o coração e o próximo como a nós mesmos","387.

Além disso, Irineu demonstra que a Igreja é fruto do resgate de Deus daqueles que se perderam e não foram evangelizados pelos judeus, que receberam o primeiro anúncio. Citando o profeta Oséias, o bispo de Lião declara: “chamarei meu povo àquele que não é meu povo e Amada àquela que não é amada. $E$ acontecerá que, no lugar onde lhes foi dito: vós não sois meu povo, lá serão

\footnotetext{
${ }^{383}$ ORBE, A., Teología de san Ireneo IV, p. 362.

${ }^{384}$ IRINEU de Lião, Epideixis 62.

${ }^{385}$ IRINEU de Lião, Epideixis 91.

${ }^{386}$ IRINEU de Lião, Epideixis 95.

${ }^{387}$ IRINEU de Lião, Epideixis 95.
} 
chamados filhos do Deus vivo" (Rm 9,25-26) ${ }^{388}$. Assim Irineu mostra que, das pedras, Deus pode suscitar filhos de Abraão (Mt 3,9), arrancando-os do culto das pedras - forma como Irineu trata os povos pagãos -, para que sejam justificados pela fé $(\mathrm{Rm} 3,28)$. A Igreja torna-se a grande obra de Deus para reunir, de todos os povos, os que ouviram sua Palavra, o Verbo de Deus, e trocaram seus corações de pedra por um novo coração de carne. Então esse será o meu povo e eu serei o seu Deus (Ez 11,19-20; 36,26-27) ${ }^{389}$.

Irineu afirma que os filhos que o profeta Oséias ${ }^{390}$ teve ao desposar a prostituta, receberam os nomes de "Aquela que não obteve misericórdia" e "Não povo" (Os 1,6-9). A primeira é nomeada como profecia real da Igreja, que viria da tradição de Israel, e o segundo filho como o povo que viria da gentilidade para constituir a Igreja do Senhor. Irineu unifica, segundo A. Orbe, estes dois povos num único povo, chamando-os de "Filhos do Deus vivo", frutos das união entre Cristo e a sua Igreja, pois, dessa forma, foram purificados, formando a comunidade dos filhos de Deus ${ }^{391}$. "Assim também Moisés tomava por esposa uma etíope, tornando-a, com isso, israelita, preanunciando que a oliveira selvagem seria enxertada na oliveira boa e participaria da sua riqueza". 392

Novamente, a união entre Cristo e a Igreja é prefigurada em Moisés, representando Israel, e na etíope, representando a gentilidade. No entanto, Irineu apresenta um detalhe especial, segundo A. Orbe, pois, ao nascer em Belém, os israelitas quiseram matar o Verbo de Deus, e foram os gentios, neste caso, o reino do Egito que acolheu e protegeu o Filho de Deus.

Aqui se levanta uma crítica de Irineu aos valentinianos que não acreditavam na Encarnação do Verbo, muito menos na salvação da natureza humana, pois, para eles, a Igreja era composta por seres espirituais ou homens espirituais. $\mathrm{O}$ bispo de Lião mostra que a Igreja de Deus não é composta de seres espirituais, senão de homens e mulheres oriundos de todas as regiões, entre os judeus ou entre os pagãos $^{393}$.

Sendo assim, "prevendo que Deus justificaria os gentios pela fé, a Escritura anunciou a Abraão que nele seriam abençoadas todas as nações, por isso o chama

\footnotetext{
${ }^{388}$ IRINEU de Lião, Epideixis 93.

${ }^{389}$ IRINEU de Lião, Epideixis 93.

390 IRINEU de Lião, Adversus haereses IV, 20, 12.

${ }^{391}$ ORBE, A. Teología de san Ireneo IV, p. 316.

392 IRINEU de Lião, Adversus haereses IV, 20, 12.

${ }^{393}$ ORBE, A., Teología de san Ireneo IV, p. 317.
} 
não somente profeta da fé, mas o pai dos que entre os gentios creem em Cristo Jesus, porque é uma e única a sua e a nossa fé” ${ }^{, 394}$. E as promessas não se dirigiam somente aos profetas e patriarcas, mas a todas as igrejas espalhadas pelo mundo, que acolheram a Boa Nova, de modo que foram perseguidas e ultrajadas, a fim de que pudessem encontrar no Cristo um porto de salvação, longe dos perigos e refugiadas contra todo erro.

Por isso Irineu dirá que estas igrejas são chamadas ilhas ${ }^{395}$, não porque estão isoladas, mas sim presentes neste mar de paganismo, são um sinal da graça de Deus. Reunidas pelo Espírito de Deus, conforme A. Orbe, formam a Igreja de Jesus Cristo, a qual acolhe a todos que se dispuseram a sair da mentira para viver a verdade das Escrituras ${ }^{396}$.

Na história de Jacó, Irineu reafirma a perspectiva apresentada anteriormente, em que de dois povos nasce um único povo de Deus, pois ao vencer o irmão Esaú e conquistar a primogenitura, Jacó prefigura o Cristo que nasce no meio de Israel e vence o poder do mal na cruz; da mesma forma a Igreja vence sobre a sinagoga e passa a ser perseguida por esta, como Jacó foi perseguido por Esaú. Neste triunfo, todos os povos herdam da vitória de Cristo sobre o pecado, ou seja, a vitória que o segundo Adão obtém sobre o primeiro.

Deste modo, da descendência de Jacó “em terra estrangeira nasciam as doze tribos, os filhos de Israel, porque também o Cristo devia gerar em terra estrangeira as doze colunas, fundamento da Igreja"397. Ou seja, Jacó e seus filhos peregrinaram no Egito, em terra estrangeira, onde cresceram e se multiplicaram. $\mathrm{O}$ povo cristão, para A. Orbe, também nasce peregrino em todas as nações, como uma Igreja da gentilidade que tem nos apóstolos seu fundamento e em Cristo o seu Senhor ${ }^{398}$. Por isso, a Igreja em todos os povos é o redil de Cristo, cujo “salário são os homens que de várias e diferentes nações se reúnem no único redil da fé, como o Pai lhe havia prometido"399 , assim como o salário de Jacó eram as ovelhas malhadas.

Da mesma maneira como Jacó sonhava em se casar com Raquel, a mais jovem, mas foi enganado pelo sogro, que lhe deu Lia em virtude do sofrimento,

\footnotetext{
${ }^{394}$ IRINEU de Lião, Adversus haereses IV, 21, 1; IV, 8, 1; V, 34, 1.

395 IRINEU de Lião, Adversus haereses V, 34, 3.

${ }^{396}$ ORBE, A., Teología de San Ireneo III, p. 472-473.

${ }^{397}$ IRINEU de Lião, Adversus haereses IV, 21, 3.

${ }^{398}$ ORBE, A., Teología de san Ireneo IV, p. 328.

${ }^{399}$ IRINEU de Lião, Adversus haereses IV, 21, 3.
} 
para depois receber a amada Raquel, Cristo sofre por nós nas mãos dos judeus, prefigurados em Lia, a mais velha e não amada, para receber em vitória todas as nações, prefiguradas na amada Raquel, na sua Esposa, a Igreja ${ }^{400}$.

Outra prefiguração da Igreja apresentada por Irineu parte do êxodo da Igreja como tipologia do paganismo, que é introduzido diretamente por Cristo, não por Moisés, na herança definitiva ${ }^{401}$. O primeiro êxodo, do povo de Deus libertado da ira do Faraó, é sinal e prefiguração do segundo êxodo da Igreja, que é formada pelos judeus e pagãos caminhando para o Reino definitivo e para a herança que Deus lhe preparou. A Igreja peregrina neste mundo caminha para o Reino dos céus $^{402}$.

Nessa índole escatológica da Igreja, a Aliança entre Deus e o povo libertado do Egito tem seu desfecho na construção da habitação do Senhor (Ex 25,8), onde o próprio Deus habitará no meio do seu povo. Irineu entende essa habitação como uma "construção visível na terra das realidades espirituais e invisíveis do céu, figura da Igreja e representação profética das realidades futuras" ${ }^{\text {403 }}$. De fato, a Igreja é a concretização da promessa de Deus com o seu povo e nela o próprio Senhor habita, enquanto é o Corpo do Senhor.

Irineu também demonstra que, com a Encarnação, o Verbo de Deus veio fazer morada entre nós, concretizando o novo chamado a todos os povos, para renovar seus corações. Com isso, a Igreja anuncia a Boa Nova, para gerar "um grande número de salvos, porque não é mais um intercessor, Moisés, ou um enviado, Elias, que a salva, mas o Senhor mesmo, que gera mais filhos à Igreja que à sinagoga do passado"404. A igreja-sinagoga, dos primeiros tempos, era estéril, pois desposou a Lei e não o Senhor. Porém, a Igreja Corpo de Cristo assume em si a concretização da profecia de Isaías: "Entoa alegre canto, ó estéril, que deste à luz; ergue gritos de alegria, exulta, tu que não sentiste as dores de parto, porque mais numerosos são os filhos da abandonada do que os filhos da esposa, diz Yahweh" (Is 54,1; G1 4,27) ${ }^{405}$.

\footnotetext{
${ }^{400}$ ORBE, A., Teología de san Ireneo IV, p. 330.

${ }^{401}$ IRINEU de Lião, Adversus, haereses IV, 30, 4.

${ }^{402}$ IRINEU de Lião, Adversus, haereses V, 27, 2; V, 29, 1.

${ }^{403}$ IRINEU de Lião, Epideixis 26.

${ }^{404}$ IRINEU de Lião, Epideixis 94.

${ }^{405}$ IRINEU de Lião, Epideixis 94.
} 
Ao explicar que o ser humano é alma, corpo e espírito ${ }^{406}$, afirma que toda “criatura é o templo de Deus (1Cor 3,16-17), evidentemente chamando o corpo de templo em que habita o Espírito" 407 . Cada cristão carrega consigo a graça de ser templo de Deus, pelo Espírito que habita em seu coração, enquanto a comunhão entre os irmãos os remete ao texto bíblico pelo qual entendem que os próprios “corpos são membros de Cristo $(1$ Cor 6,15)",408.

Ora, os membros têm com Cristo uma união mais íntima que as pedras de uma construção têm entre $\mathrm{si}^{409}$, do mesmo modo como a terceira visão de Hermas descrevia, contemplando a construção de uma Torre edificada com pedras de várias origens, que "se ajustavam imediatamente na construção perfeitamente às outras pedras; ajustavam-se tão bem umas com as outras, que não se via juntura, e a torre parecia construída como um só bloco" ${ }^{\natural 10}$. Os membros de Cristo, segundo A. Orbe, estão tão unidos ao seu Senhor que formam um único Corpo, "o Corpo glorioso de Cristo" ${ }^{411}$, cuja unidade é ameaçada pelos que se afastam da verdade que está na Igreja. Estes julgam os irmãos sem misericórdia e estão interessados somente nas próprias vidas, assim querendo rasgar e dividir o Corpo de Cristo $^{412}$.

Por isso, o bispo de Lião afirma que "a verdadeira gnose é a doutrina dos apóstolos, é a antiga difusão da Igreja em todo o mundo, é o caráter distintivo do Corpo de Cristo que consiste na sucessão dos bispos aos quais foi confiada a Igreja em qualquer lugar ela esteja"413. Deste modo, segundo G. Jossa, o conhecimento da regula veritatis possibilita a unidade da Igreja $^{414}$, que se expressa no mundo por meio da fidelidade dos apóstolos aos ensinamentos do Senhor. A transmissão desses ensinamentos a todo homem e mulher de boa vontade não passa por uma escolha ou seleção do conteúdo, mas é destinada a quem os acolhe com generosidade e deseja ser iluminado pela verdade da fé em Cristo Jesus, tornando-se, assim, templo do Espírito de Deus.

\footnotetext{
${ }^{406}$ OSBORN, E., Irenaeus of Lyons, p. 219-220; IRINEU de Lião, Adversus haereses V, 6, 1-2; GONÇALVES, P.; PIACENTE, L., Antropologia espiritual de Irineu de Lião, p. 39-50.

${ }^{407}$ IRINEU de Lião, Adversus haereses V, 6, 2.

${ }^{408}$ IRINEU de Lião, Adversus haereses V, 6, 2.

${ }^{409}$ ORBE, A., Teología de San Ireneo I, p. 313-316.

${ }^{410}$ HERMAS, O Pastor, Visão III, 10, 6.

${ }^{411}$ IRINEU de Lião, Adversus haereses IV, 33, 7.

${ }^{412}$ ORBE, A., Teología de San Ireneo IV, p. 460; remete diretamente a Clemente Romano, Carta aos Coríntios, que era conhecida por Irineu (III, 3, 3) e se apropria dos ensinamentos dele para combater a divisão na Igreja.

${ }^{413}$ IRINEU de Lião, Adversus haereses IV, 33, 8.

${ }^{414}$ JOSSA, G., Regno di Dio e chiesa, p. 210-212.
} 
Em consequência, a Igreja se configura como imagem do Filho de Deus ${ }^{415}$, pois reúne nas suas fileiras os que são membros de Cristo e templos do Espírito de Deus, agregando em si cada membro para formar o Corpo, cuja cabeça é Cristo ${ }^{416}$. Pela unidade com seu Senhor, a Igreja recebe coesão e crescimento ${ }^{417}$, de modo que a comunidade, por meio das juntas e ligamentos com o Cristo cabeça $(\mathrm{Cl}$ 2,19), recebe o alimento para o seu crescimento em Deus e torna-se consubstancial com o Senhor.

Já que “o Verbo que é a cabeça da Igreja, em todos há o Espírito, e Ele é a água viva que o Senhor dá aos que nele creem com retidão, que o amam, e que

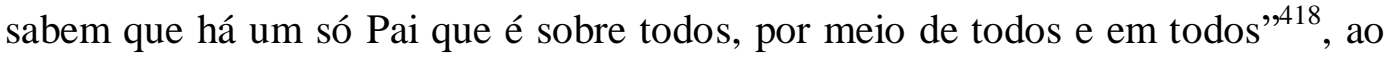
final dos tempos, na Igreja celeste, todos os membros do Corpo louvarão e glorificarão ao Pai, pela plenitude da vida conquistada pelo seu Filho Jesus ${ }^{419}$.

Na compreensão da Igreja como Corpo de Cristo, segundo Scordamaglia, está inserida a compreensão da doutrina da recapitulação ${ }^{420}$, que pode ser compreendida na perspectiva eclesiológica. Para Irineu, o Filho sempre existiu junto do Pai, mas "quando se encarnou e se fez homem, recapitulou em si toda a longa série dos homens, dando-nos a salvação, que tínhamos perdido em Adão, isto é, a imagem e semelhança de Deus, o recuperássemos em Jesus Cristo" ${ }^{421}$. Ou seja, Irineu demonstra que Jesus Cristo restaurou ${ }^{422}$ com sua encarnação, em sua pessoa, toda a criação, trazendo a harmonia original que havia sido quebrada pelo pecado, pois, a partir da sua imortalidade, restabeleceu a incorruptibilidade, que atingirá sua plenitude na ressurreição e na vivência com o Senhor. "Nunca poderíamos obter a incorrupção e a imortalidade a não ser unindo-nos à incorrupção e à imortalidade. E como poderíamos realizar esta união sem que antes a incorrupção e a imortalidade se tornassem o que somos" ${ }^{\text {"423 }}$, e deste modo podemos receber a adoção filial de Deus.

\footnotetext{
415 IRINEU de Lião, Adversus haereses IV, 37, 7.

${ }^{416}$ IRINEU de Lião, Adversus haereses IV, 34, 4.

${ }^{417}$ IRINEU de Lião, Adversus haereses V, 14, 4.

${ }^{418}$ IRINEU de Lião, Adversus haereses V, 18, 2.

${ }^{419}$ IRINEU de Lião, Adversus haereses V, 8, 1.

${ }^{420}$ FAUS, J., Carne de Dios, p. 163-190; SCORDAMAGLIA, D., Ritratti di Cristo in Sant'Ireneo, p. 296-300; ANDIA, Y., Irénée, théologien l'unité, p. 44.

${ }^{421}$ IRINEU de Lião, Adversus haereses III, 18, 1.

${ }^{422}$ IRINEU de Lião, Adversus haereses III, 21, 10; IV, 14, 2. Irineu demonstra que Deus não modela uma segunda criação do ser humano, mas restaura a sua obra criada à imagem e semelhança, em Cristo Jesus.

${ }^{423}$ IRINEU de Lião, Adversus haereses III, 19, 1.
} 
A comunhão entre a cabeça e o corpo (Ef 5,23-24; Col 1,18), segundo Y. Andia, ou seja, entre Cristo e a Igreja, dá-se pela adesão dos membros de Cristo à ressurreição; e nela o homem é chamado à comunhão com Deus, para que, por meio da comunhão, com Ele participemos da incorruptibilidade ${ }^{424}$. Recapitulou todas as coisas em si para que, como o Verbo de Deus tem a "primazia entre os seres celestes, espirituais e invisíveis, a tivesse também entre os seres visíveis e corporais, e para que, ao assumir em si esta primazia e ao tornar-se cabeça da Igreja, atraísse a si todas as coisas, no tempo oportuno" ${ }^{425}$.

Ele constituiu a si mesmo como primícia da ressurreição, porque, como a cabeça ressuscitou dos mortos, assim devem ressuscitar os outros membros - isto é, todos os homens que serão encontrados na vida, uma vez que tiver passado o tempo da condenação da desobediência - , a fim de serem mantidos juntos por meio de articulações e junturas, fortalecidos pelo desenvolvimento produzido por Deus, onde encontrarão o seu lugar conveniente. São muitas as mansões na casa do Pai, porque muitos são os membros do corpo ${ }^{426}$.

Repetidamente, Irineu afirma que a Igreja é a portadora da verdade revelada pelo Senhor por meio de seu Ungido, porque "não é necessário procurar noutras pessoas aquela verdade que facilmente podemos encontrar na Igreja”427. Esta verdade nos vem pela Tradição apostólica, como num rico armazém, em que "tudo o que pertence à verdade, a fim de que cada um que [a] deseje, encontre aí a bebida da vida"428. A Igreja é definitivamente o caminho de acesso à vida e "todos os outros são assaltantes e ladrões que é mister evitar" 429 .

Irineu reconhece que o mesmo Deus e Senhor governa todos os seres humanos em todos os tempos e momentos, por isso não há divisão na Igreja, como afirmavam os gnósticos que diferenciavam os que pertencem ao mundo espiritual dos que pertencem ao mundo material, criados pelo Demiurgo. Para isso, segundo A. Orbe, utilizavam várias interpretações bíblicas, como a divisão em duas partes do véu do Santuário, com a morte de Cristo (Mt 27,51) ${ }^{430}$. Em contrapartida, Irineu argumenta a unidade entre ambos os testamentos, pois "os patriarcas e os

\footnotetext{
${ }^{424}$ IRINEU de Lião, Epideixis 40.

${ }^{425}$ IRINEU de Lião, Adversus haereses III, 16, 6

${ }^{426}$ IRINEU de Lião, Adversus haereses III, 19, 3; ANDIA, Y., Irénée, théologien l'unité, p. 45-46.

${ }^{427}$ IRINEU de Lião, Adversus haereses III, 4, 1.

${ }^{428}$ IRINEU de Lião, Adversus haereses III, 4, 1.

${ }^{429}$ IRINEU de Lião, Adversus haereses III, 4, 1.

${ }^{430}$ ORBE, A., Teología de san Ireneo IV, p. 341.
} 
profetas semearam as palavras que se referem a Cristo, e a Igreja ceifou, isto é, recolheu os frutos" ${ }^{\prime 31}$.

Por conseguinte, Cristo não veio somente pelos que creram nele no tempo de Tibério César; e o "Pai não exerceu somente a sua providência para os homens de então, mas para todos os homens que temeram e amaram a Deus, praticaram a justiça e a bondade para com o próximo, desejaram ver o Cristo e ouvir a sua voz" ${ }^{432}$. Estavam os cristãos tão prefigurados nos que receberam o primeiro anúncio quanto representados nos que hoje compõem a Igreja.

Rejeitando, assim, as teorias gnósticas que tentavam afirmar que Deus não estava presente na sua obra criada, Irineu afirma que "somente resta verdadeira a afirmação da Igreja segundo a qual a própria criação de Deus, feita pelo poder, a arte e a sabedoria dele, pode sustentar Deus" ${ }^{233}$. A Igreja garante e compreende, conforme A. Orbe, na realidade presente, a verdade sobre o Senhor, custodiando a Revelação e transmitindo-a aos seus filhos ${ }^{434}$. "A pregação da Igreja é, portanto, verdadeira e firme e nela há caminho único e idêntico em todo o mundo. A ela foi concedida a luz de Deus"435.

A Igreja invisível ou espiritual, segundo A. Orbe, defendida pelos gnósticos, não se aplica à Igreja de Jesus Cristo, pois se fosse invisível não poderia ser a presença do Senhor no mundo nem poderia anunciar a Boa Nova. Com isso, Irineu afirma que a Igreja está à vista de todos, pois ela é “como paraíso plantado neste mundo" "436, plantada por Deus no Jardim do Éden (Gn 2,8), no mesmo tempo em que Adão e Eva foram modelados do pó da terra. Nesta prefiguração, as árvores plantadas neste mundo são as Escrituras - todas e cada uma das palavras, que são oferecidas pela Igreja como alimento aos justos.

De fato, a Palavra de Deus não serve somente aos crentes, mas também está disponível aos hereges, ou seja, a Igreja não é mãe somente dos batizados, ela também vai em busca dos que são seus e não estão no redil das ovelhas ${ }^{437}$ :

portanto, comereis do fruto de todas as árvores do paraíso, diz o Espírito de Deus, o que significa: alimentai-vos de todas as Escrituras divinas, mas não o façais com

\footnotetext{
${ }^{431}$ IRINEU de Lião, Adversus haereses IV, 25, 3.

${ }^{432}$ IRINEU de Lião, Adversus haereses IV, 22, 2.

${ }^{433}$ IRINEU de Lião, Adversus haereses V, 18, 1.

${ }^{434}$ ORBE, A., Teología de San Ireneo II, p. 207-208.

435 IRINEU de Lião, Adversus haereses V, 20, 1.

${ }^{436}$ IRINEU de Lião, Adversus haereses V, 20, 2.

${ }^{437}$ ORBE, A., Teología de San Ireneo II, p. 327-328; ORBE, A., Antropología de San Ireneo, p. 244-245
} 
intelecto orgulhoso e não tenhais nenhum contato com a dissensão dos hereges. Eles afirmam possuírem o conhecimento do bem e do mal e elevam seus pensamentos acima do Deus que os criou, e com a sua inteligência ultrapassam a medida da inteligência ${ }^{438}$.

Destarte, o bispo de Lião demonstra que há na Igreja plantada pelo mundo todo, segundo J. Behr ${ }^{439}$, uma unidade nas preces, nas práticas, mas principalmente no anúncio e na profissão de fé. Neste sentido, os caminhos da Igreja "percorrem o mundo inteiro conservando a sólida tradição que vem dos apóstolos, mostrando-nos uma única e idêntica fé em todos"

Essa fé una e idêntica de toda multidão dos crentes espalhados pelo mundo sustém o testemunho verdadeiro da Igreja, porque, se todos pregam, ensinam, celebram as mesmas verdades de fé, o sinal deixa de ser humano para se tornar mais divino, segundo A. Orbe ${ }^{441}$. É possível compreender isso na interpretação de Irineu da profecia de Isaías (Is 43,18-21), na qual compara a fé em Cristo com o “caminho da justiça aberto no deserto e os rios do Espírito Santo brotados na terra árida, para matar a sede da raça escolhida de Deus" ${ }^{\$ 42}$.

O próprio Senhor vem em socorro do ser humano criado, para conduzi-lo ao seu verdadeiro caminho, a fim de que a Igreja receba a missão de professar e propagar essa única fé em todos os cantos. Como prova, Irineu não somente apresenta a importância da tradição e da sucessão apostólica, como também da hierarquia eclesiástica, como estrutura em que todos "observam os mesmos preceitos, conservam a mesma forma de organização da Igreja, esperam a mesma vinda do Senhor e a mesma salvação de todo o homem, isto é, da alma e do corpo",433. Em consequência, para a Igreja não se tornar invisível, como preconizavam os gnósticos, ao descrevê-la em sua realidade visível e temporal, Irineu segue os passos de Inácio de Antioquia:

nas pessoas acima designadas eu vi e amei na fé toda a vossa comunidade. Estejais dispostos a fazer todas as coisas na concórdia de Deus, sob a presidência do bispo, que ocupa o lugar de Deus, dos presbíteros, que representam o colégio dos apóstolos, e dos diáconos, que são muito caros para $\operatorname{mim}^{444}$.

\footnotetext{
${ }^{438}$ IRINEU de Lião, Adversus haereses V, 20, 2.

${ }^{439}$ BEHR, J., Irenaeus os Lyons, p. 167-168.

${ }^{440}$ IRINEU de Lião, Adversus, haereses V, 20, 1.

${ }^{441}$ ORBE, A., Teología de San Ireneo II, p. 302.

${ }^{442}$ IRINEU de Lião, Adversus haereses IV, 33, 14; IRINEU de Lião, Epideixis, 89.

${ }^{443}$ IRINEU de Lião, Adversus, haereses V, 20, 1.

${ }^{444}$ INÁCIO de Antioquia, Carta aos Magnésios 6,1.
} 
Os que estão à frente da Igreja não representam a si mesmos, mas exercem o ministério ao qual o Senhor lhes chamou, de modo que essa unicidade da fé eclesial se sustente pela fidelidade dos que a anunciam e pela confiança que aqueles que creem depositam nos seus ministros.

Portanto, a Igreja caracterizada por Irineu, no início do Adversus haereses, como o "edifício de Deus" 445 , constituída dos inúmeros fiéis que acolheram a Boa Nova e assumiram um novo caminho pelo batismo, já não é a vinha cercada e entregue aos vinhateiros homicidas, como relata Mateus (21,33-43). Pelo contrário, mostra-se sem tal cerca, para que possa ser compreendida pelo mundo inteiro com novos vinhateiros, que virão para cultivar e recolher seus frutos no tempo certo.

O Senhor não colocou uma torre de vigia como sinal na sua vinha, mas a "torre da eleição que se levanta em todo lugar, no seu esplendor, pois a Igreja brilha em todo lugar" ${ }^{\prime 46}$. A Igreja é a torre resplandecente que Deus colocou na sua vinha para atrair para si todas as pessoas, de todas as nações e em todos os caminhos para a festa de casamento do Esposo-Filho com a Esposa-Igreja ${ }^{447}$.

De fato, o Senhor está chamando as pessoas, desde a convocação dos povos, por meio dos patriarcas, dos profetas e dos sábios. Na plenitude dos tempos, realizou um chamado definitivo pelo Filho, que enviou os apóstolos e discípulos. Irineu demostra isso no relato da parábola dos operários enviados a trabalhar na vinha em horas diferentes (Mt 20,1-16), pois aí torna-se clara a tipologia do único e mesmo Pai, que convoca seus filhos e filhas em tempos e momentos diferentes para trabalharem na sua vinha ${ }^{448}$.

A Igreja, por conseguinte, é a grande mediadora desse chamado de Deus, pois como Corpo de Cristo, edifício de Deus, foi deixada neste mundo como sal da terra, a exemplo da mulher de $\operatorname{Lot}^{449}$. Ora, "a Igreja, deixada nas regiões da terra para suportar as vicissitudes humanas e, enquanto lhe são continuamente tirados os membros, continua a ser a estátua de sal intacta, isto é, fundamento da fé que confirma seus filhos e os envia diante do seu Pai" ${ }^{450}$.

\footnotetext{
${ }^{445}$ IRINEU de Lião, Adversus haereses I, prefácio 1.

${ }^{446}$ IRINEU de Lião, Adversus haereses IV, 36, 1-4.

${ }^{447}$ IRINEU de Lião, Adversus haereses IV, 36, 5-6.

${ }^{448}$ IRINEU de Lião, Adversus haereses IV, 36, 7.

${ }^{449}$ IRINEU de Lião, Adversus haereses IV, 31, 3.

${ }^{450}$ IRINEU de Lião, Adversus haereses IV, 31, 3.
} 
A. Orbe ${ }^{451}$ afirma que, para Irineu, a Igreja simbolizada pela mulher de Lot é a Esposa de Cristo na terra, que está entre os seres viventes, mas também os encaminha para a glória celeste; como "estátua de sal", ela representa a Igreja coluna e sustentáculo da fé, que conserva seus filhos para a verdadeira vida em Cristo. Ela durará até a consumação dos séculos como sacrifício agradável a Deus, entre a perseguição e o sofrimento.

A Igreja sal da terra é estéril, pois não gera filhos para si mesma, mas os resgata, entregando-os ao Reino do Esposo, para compor a Igreja celeste que é fecunda. Como coluna da fé, a Igreja vive um fenômeno incompreensível aos olhos humanos: quanto mais perseguidos forem seus membros, mais eles se multiplicam. Logo, a Igreja sal da terra se mantém em pé, íntegra, como uma mãe que trabalha duramente na terra para entregar os seus filhos, os mártires, ao Cristo, o Esposo, para salvá-los.

De igual modo, a Igreja permanece nos confins da terra, sempre em busca dos filhos e filhas, para reuni-los no único rebanho de Cristo. Não para condenálos ou expulsá-los do redil das ovelhas, mas, por agregação, conduzi-los ao Reino de Deus.

\subsubsection{2. \\ A importância do batismo}

O batismo ${ }^{452}$, segundo Irineu, marca a adesão ao projeto de Deus anunciado por Jesus Cristo por meio dessa força essencial recebida no banho batismal, onde o crente se torna plenamente unido ao Filho de Deus e à sua missão. Com o batismo se compreende a dinâmica de participação no mistério da recapitulação de Jesus Cristo por parte daqueles que se deixam marcar com o sigilo da graça do Senhor e assim recebem a libertação que Ele derramou sobre todos ${ }^{453}$. Também é possível compreender, a partir da interpretação de Irineu, a teologia sacramental sobre o batismo, condicionada à salvação iniciada na Encarnação, que o Espírito torna sólida na vida dos que $\mathrm{creem}^{454}$.

\footnotetext{
${ }^{451}$ ORBE, A., Teología de San Ireneo IV, p. 440-446.

${ }^{452}$ HOUSSIAU, A., Le baptêmê selon Irénée de Lyon, p. 45-59, este artigo é uma referência no estudo do batismo em Irineu de Lião, além de ser citado por vários outros autores.

${ }^{453}$ IRINEU de Lião, Adversus haereses IV, 9, 2.

${ }^{454}$ GROSSI, V., Linee di ecclesiologia patrística, p. 39.
} 
Com efeito, "nossos corpos receberam, pelo banho do batismo, a unidade que os torna incorruptíveis e as nossas almas, por sua vez, a receberam pelo Espírito; por isso, ambos são necessários porque ambos levam à vida de Deus" ${ }^{\$ 45}$. Irineu recorda que a graça do Espírito em Pentecostes introduziu os apóstolos, os discípulos e os ouvintes numa vida nova, abrindo para eles um novo testamento e reunindo as diferentes raças e povos numa mesma unidade, para cumprir assim a profecia de Joel $(3,1-5)$ e para oferecer ao Pai as primícias das nações. É o banho batismal, segundo I. Oñatibia, pela água e pelo Espírito, que possibilita a constituição de um novo povo de Deus ${ }^{456}$, homens e mulheres novos que se tornam um só em Cristo. Sendo assim, conforme V. Grossi e A. Di Berardino, como o próprio bispo de Lião afirmou que todos somos membros deste grande Corpo de Cristo, unidos e reunidos pelo Espírito, embora não apresente uma teologia especulativa específica, torna evidente que pelo batismo os seres humanos recebem a graça que os agrega ao Senhor, constituindo, assim, o povo de $\operatorname{Deus}^{457}$.

A partir disto, Irineu, afirma a importância do batismo para a vida cristã, antes de tudo, a fé nos convida com insistência a recordar que recebemos o batismo para a remissão dos pecados em nome de Deus Pai e em nome de Jesus Cristo, Filho de Deus encarnado, morto e ressuscitado, e no Espírito Santo de Deus; que o batismo é o selo da Vida Eterna, o novo nascimento em Deus, de modo que já não somos mais filhos de homens mortais, mas de Deus eterno e indefectível; que o Eterno e o Indefectível é Deus, acima de todas as criaturas, e que cada coisa, de qualquer espécie, está sujeita a Ele, e o que está sujeito a Ele foi por Ele criado ${ }^{458}$.

Por meio do batismo os convocados pelos apóstolos - judeus e gentios - são redimidos do pecado que os afastou da comunhão da Trindade, purificando assim suas almas e seus corpos de todos os ídolos, fornicação e avareza ${ }^{459}$. Os batizados obtêm a garantia da vida eterna no Senhor, pois receberam o novo nascimento concedido pelo Pai, por meio do Filho e no Espírito Santo, tornando-se, assim, eternos e indefectíveis ${ }^{460}$.

Irineu também afirma que aqueles que, pelo batismo, "foram, assim, libertados, Deus não quer conduzi-los sob a Lei de Moisés; mas [quer] que caminhemos livres na novidade dada pela fé no Filho de Deus, na renovação da

\footnotetext{
${ }^{455}$ IRINEU de Lião, Adversus haereses III, 17, 2; Epideixis 42.

${ }^{456}$ IRINEU de Lião, Epideixis 88; OÑATIBIA, I., batismo e confirmação, p. 183-184.

${ }^{457}$ GROSSI, V.; DI BERARDINO, A., La Chiesa antica, p. 34-35.

${ }^{458}$ IRINEU de Lião, Epideixis 3.

${ }^{459}$ IRINEU de Lião, Epideixis 100; 41; IRINEU de Lião, Adversus haereses III, 12, 7.

${ }^{460}$ IRINEU de Lião, Epideixis 100; 6-7; OÑATIBIA, I., batismo e confirmação, p. 194-196.
} 
Palavra"461. Para tanto, a doutrina dos apóstolos se tornou as doze fontes que se espalham sobre o deserto, irrigando todas as regiões com a Boa Nova de Jesus Cristo e levando muitos ao encontro com o Senhor ${ }^{462}$.

A partir de prefigurações do Antigo Testamento, Irineu demonstra que o Senhor já dava sinais dessa vida nova oferecida a cada um que reconhecesse o seu chamado de vida. Após o "dilúvio, Deus estabeleceu um pacto de aliança com os animais e com os homens, afirmando que jamais destruiria o que refloresceria sobre a terra" ${ }^{463}$. Assim, abençoou os filhos de Noé para que pudessem crescer e multiplicar-se. A referida aliança lavou e libertou a criação do mal, mesmo que esta se voltasse ao pecado. Deus estabeleceu o seu arco no céu como sinal da aliança com os seres humanos.

Além disso, Irineu, ao afirmar que Igreja é o êxodo, como já apresentado acima, demonstra que esta estava prefigurada nos que foram salvos "do mar vermelho, isto é, liberando-os das turbulências homicidas dos gentios, e das águas amargas de suas blasfêmias" ${ }^{\text {"64 }}$. Consequentemente, os que foram lavados no mar e na fé, ao perceberem o sinal de Deus, que abriu o mar e os libertou da mão do faraó, creram no Senhor, que os trouxe à vida verdadeira.

No entanto, foi no fim dos tempos que Deus manifestou claramente sua misericórdia e seu amor pelo seu povo eleito, "porque abriu o testamento da adoção filial[e] os que receberam o Espírito de adoção, isto é, os que creram no verdadeiro Deus e em Cristo Jesus, Filho de Deus" ${ }^{465}$ constituíram a Igreja, a comunidade dos que são perfeitos pela graça do Espírito de Deus e nele reencontraram a vida ${ }^{466}$.

Da mesma forma que Josué ${ }^{467}$ atravessou o rio Jordão e venceu os sete povos, dando ao povo de Deus a terra prometida, segundo C. Granado, Jesus adentrou o Jordão e foi batizado por João ${ }^{468}$, convocando o novo povo de Deus a

${ }^{461}$ IRINEU de Lião, Epideixis 89.

${ }^{462}$ IRINEU de Lião, Epideixis 46.

${ }^{463}$ IRINEU de Lião, Epideixis 22.

${ }^{464}$ IRINEU de Lião, Epideixis 46; 25.

${ }^{465}$ IRINEU de Lião, Epideixis 8; IRINEU de Lião, Adversus haereses IV, $1,1$.

${ }^{466}$ IRINEU de Lião, Adversus haereses V, 6, 1; V, 12, 3.

${ }^{467}$ IRINEU de Lião, Epideixis 29.

${ }^{468}$ GRANADO, C., El Espiritu Santo em la teologia patrística, p. 38-39; ORBE, A., Introduccion a la teologia de los siglos II y III, p .666. 
assumir a promessa feita a Abraão e concretizada no Cristo. É nele, segundo Fantino, que todos nos tornamos verdadeiramente filhos adotivos de Deus ${ }^{469}$.

Posto isto, Irineu faz uso da imagem da oliveira silvestre e da oliveira mansa, apresentada por Paulo na carta aos Romanos (11,16-24), para mostrar como os que abandonam os falsos ídolos e as teorias errôneas assumem sua vocação de filhos no Filho. "Se uma oliveira silvestre, depois de enxertada, continua silvestre como antes, será cortada e lançada ao fogo. Se, porém, conserva o enxerto, transforma-se em oliveira mansa e torna-se frutífera, é como se fosse plantada no jardim do rei” ${ }^{470}$. Ora, a oliveira abandonada no deserto, sem os cuidados necessários, torna-se silvestre e produz frutos da sua condição. Assim são os seres humanos que se afastaram do Senhor, quando não ouvem sua voz, nem vivem os seus mandamentos, perdendo-se na concupiscência da carne e produzindo os frutos da sua própria condição.

Todavia, se estes homens "estéreis em frutos de justiça e como cultura invadida pelo mato são rodeados de cuidados e recebem, como enxerto, a Palavra de Deus, voltam à natureza primitiva do homem, a que foi criada à imagem e semelhança de Deus" ${ }^{471}$. O "enxerto da Palavra de Deus", segundo E. Osborn, do Verbo de Deus que tudo criou e, no mistério da encarnação, recapitulou toda a obra de Deus ${ }^{472}$, possibilita ao ser humano recuperar a sua dignidade primeira, como novo Adão, purificado e restabelecido no vínculo de vida com o Senhor. Portanto, ao afirmar que este homem enxertado no Cristo é plantado no jardim do rei, Irineu remete à imagem da Igreja como o jardim de Deus, que acolhe e agrega todos os filhos e filhas ao Pai. Estes são os que creem nele e fazem a sua vontade $^{473}$.

Consequentemente, é possível ver nesta oliveira, mansa e cultivada, os verdadeiros frutos do enxerto em Cristo, ou seja, os frutos da ação do Espírito que torna aquele homem perfeito ${ }^{474}$. Resgatado na sua dignidade e agregado ao novo Povo de Deus, transforma-se em lumiar, que resplandece a Luz de Cristo para $\operatorname{todos}^{475}$. Na sua economia, Deus "justificou os circuncisos em vista da fé e os

\footnotetext{
${ }^{469}$ FANTINO, J., La théologie d'Irénée, p. 211.

${ }^{470}$ IRINEU de Lião, Adversus haereses V, 10, 1.

${ }^{471}$ IRINEU de Lião, Adversus haereses V, 10, 1.

${ }^{472}$ OSBORN, E., Irenaeus of Lyons, p.132.

${ }^{473}$ IRINEU de Lião, Adversus haereses V, 10, 2; V, 12, 4; IV, 41, 2; V, 12 , 6.

${ }^{474}$ IRINEU de Lião, Adversus haereses V, 11, 1.

${ }^{475}$ IRINEU de Lião, Adversus haereses IV, 7, 3.
} 
incircuncisos pela fé" ${ }^{476}$; os primeiros como prefiguração do que éramos, enquanto "são representados em nós, isto é, na Igreja"477.

Vale notar, de acordo com A. Orbe, que aqui Irineu mostra a circuncisão como o sinal que identificava os que pertenciam ao Senhor. Entretanto, esta acabou sendo substituída pelo selo do Espírito, que não só confere a identificação, mas também lava toda culpa e agrega os fiéis como comunidade dos filhos e filhas, santificados e purificados pelo banho da vida nova em Cristo ${ }^{478}$.

De fato, conforme I. Oñatibia, os que recebem a graça da unção vinda do Alto recebem o múnus de Cristo sacerdote, profeta e rei. Pois o Cristo recebeu do Pai o seu trono glorioso e o óleo da unção, que, pelo Espírito Santo, comunica a todos os que creem; estes "são os profetas, os justos, os apóstolos, e todos os que participam do Reino" ${ }^{, 479}$.

Por conseguinte, para Irineu, a missão é muito mais importante do que a mera definição do sacramento do batismo nos nossos tempos, tão desgastado e não compreendido pela maioria dos que se aproximam da fonte batismal ou trazem seus filhos para serem lavados na fonte da nova vida. $\mathrm{O}$ seu intuito, segundo I. Oñatibia, é, primeiramente, refutar a pseudognose ${ }^{480}$, tendo por base a doutrina do Senhor e das cartas do Apóstolo, para, assim, “contrabater os hereges, converter os que se afastaram e reconduzi-los à Igreja de Deus"481.

Ademais, afirma a importância da Igreja rezar pela conversão dos que ainda não descobriram a verdade ou acabaram se afastando dela, apontando que a missão da Igreja é acolher os que abandonam o vazio, o abismo e as trevas, para assim serem "gerados como filhos legítimos, convertendo-se à Igreja de Deus"482, de modo que o Cristo possa ser formado neles. A Igreja, conforme J. Behr, é sempre misericordiosa e está de prontidão, esperando o filho mais novo voltar, para estender-lhe as mãos, sem se cansar nem desistir de nenhum dos que o Senhor lhe confiou ${ }^{483}$.

\footnotetext{
${ }^{476}$ IRINEU de Lião, Adversus haereses V, 22, 1.

${ }^{477}$ IRINEU de Lião, Adversus haereses IV, 22, 2.

${ }^{478}$ ORBE, A., Antropología de San Ireneo, p. 385; IRINEU de Lião, Adversus haereses IV, 22, 1 $2 ; \mathrm{V}, 11,2$.

${ }^{479}$ IRINEU de Lião, Epideixis 47; OÑATIBIA, I., batismo e confirmação, p. 242-243.

${ }^{480}$ OÑATIBIA, I., batismo e confirmação, p. 75-77.

${ }^{481}$ IRINEU de Lião, Adversus haereses V, prefácio.

482 IRINEU de Lião, Adversus haereses III, 25, 7.

${ }^{483}$ BEHR, J. Irenaeus of Lyons, p. 175.
} 
O zelo pastoral ativa uma preocupação crucial para que os neófitos sejam confirmados na fé de tal maneira que não caiam nas armadilhas das falsas doutrinas ${ }^{484}$. Mesmo que os gnósticos e outros hereges questionem a legitimidade do batismo na Igreja, rejeitando o caminho de seguimento do Senhor para quem aderir à fé a partir do batismo, conforme I. Oñatibia ${ }^{485}$, Irineu se agarra à firme certeza de que essa seja a verdadeira fé que recebemos dos apóstolos e eles do Senhor.

Ao invés de se apegar ao símbolo da água ou ao óleo, desde cedo, a Igreja reconhece a graça que o batismo comunica por meio dos elementos criados, mergulhando o cristão no mistério trinitário, pelo chamado que vem do Pai, pelo próprio banho batismal, na morte e ressurreição do Filho e na unção do Espírito Santo. O bispo exerce a tarefa de mediador, devendo anunciar, ensinar, exortar e conduzir as ovelhas ao encontro de Deus, renovando em cada um a dignidade que recebeu pela graça batismal ${ }^{486}$. Por esta mesma graça, foram agregados à Igreja pela purificação e pela adoção filial ${ }^{487}$, e nela oferecem um culto agradável ao Senhor, deixando de lado a oferta dos servos, para apresentar a generosa oblação dos filhos ${ }^{488}$.

\subsubsection{3. A regula fidei}

A relação entre a regula fidei $i^{489}$ e a Igreja está expressamente definida na obra de Irineu, enquanto os apóstolos e discípulos, presbíteros e diáconos, homens e mulheres da Igreja anunciaram as verdades da fé, e por essas verdades são reconhecidos como propriedade do Senhor. Muito mais que uma identificação com pessoas que agradam ou desagradam, o cristão é levado a identificar-se com o projeto do Senhor descrito pela regra de fé, pela qual ele reconhece as verdades a serem preservadas, anunciadas e refutadas.

\footnotetext{
${ }^{484}$ IRINEU de Lião, Adversus haereses V, prefácio.

${ }^{485}$ OÑATIBIA, I., batismo e confirmação, p. 173-174.

${ }^{486}$ IRINEU de Lião, Adversus haereses V, 18, 3.

${ }^{487}$ IRINEU de Lião, Adversus haereses V, 18, 2.

${ }^{488}$ IRINEU de Lião, Adversus haereses IV, 18, 2.

489 Uma completa explicação da compreensão do termo regula fidei ou veritatis, em BARBAGLIA, S., Ireneo di Lione e la comunicazione della fede cristiana, p. 97-107; FANTINO, J., La théologie d'Irénée, p. 15-27.
} 
Em Irineu, a identidade da fé e a pertença eclesial formam uma só realidade, apoiada em um processo comum. As referências abaixo demonstram como Irineu de Lião colocou em evidência a regula fidei, sobretudo como comprovação da pertença ao verdadeiro Corpo de Cristo, que é a Igreja, e como o compromisso consequente em anunciar as verdades sobre a salvação do Senhor.

Em primeiro lugar, segundo Y. Andia, diante da ameaça dos grupos gnósticos e de seus ensinamentos dentro das comunidades cristãs, Irineu de Lião afirma que "a Igreja espalhada pelo mundo inteiro até os confins da terra recebeu dos apóstolos e seus discípulos a fé em um só Deus; em um só Jesus Cristo, Filho de Deus, encarnado para nossa salvação; e no Espírito Santo" ${ }^{\text {490 }}$. Esta é a verdade da fé; é a pregação da Igreja, que anuncia em todas as realidades do mundo o que o Cristo ensinou, viveu e testemunhou. A regula fidei é a "fé que recebemos da Igreja, como depósito de grande valor em vaso precioso, que se renova e renova o próprio vaso que a contém"491. Na teologia de Irineu, a regula veritatis é utilizada para se opor às heresias gnósticas, aos sistemas por eles organizados, e assim possibilitar aos batizados a compreensão clara da fé diante das controvérsias ${ }^{492}$.

O conceito de regula fidei, segundo A. Ribeiro, é uma forma de compreender o Evangelho de Cristo, partindo do conteúdo da Revelação Cristã. Os Padres da Igreja apresentaram um conjunto de verdades de fé, que estruturavam os primeiros discursos cristãos, mesmo diante das zonas de sombra entre ortodoxia e heterodoxia, e da ausência de institucionalização para a regulação da fé. Esses primeiros Padres, que viveram nos primeiros séculos da Igreja, no período apostólico e apologista, foram os portadores da mensagem cristã e os grandes referenciais para construção dos principais artigos da fé. ${ }^{493}$

Em segundo lugar, Irineu apresenta várias vezes o conteúdo da regula fide ${ }^{494}$, reforçando para a comunidade a importância de se concentrar naquilo que é a verdade da fé, para não ceder às ilusões:

Eis a ordem da nossa fé, o fundamento do edifício e a base da nossa conduta: Deus Pai, incriado, incircunscrito, invisível, único Deus, Criador do universo. Tal é o primeiro e principal artigo de nossa fé. O segundo é o Verbo de Deus, Filho de Deus, Jesus Cristo, nosso Senhor, que apareceu aos profetas segundo o desígnio de

\footnotetext{
${ }^{490}$ IRINEU de Lião, Adversus haereses I, 10, 1.

${ }^{491}$ IRINEU de Lião, Adversus haereses III, $24,1$.

${ }^{492}$ ANDIA, Y., L'hérésie et as refutation selon Irénée de Lyon, p. 631-635.

${ }^{493}$ RIBEIRO, A., Demonstração da pregação apostólica, p. 84-85.

${ }^{494}$ IRINEU de Lião, Epideixis 6; IRINEU de Lião, Adversus haereses I, 10, 1; I, 22, 1; II, 30, 9; III, 11, 1; III, 4, 2; BENOIT, A., Ecriture et Tradition chez saint Irénée, p. 41-43.
} 
sua profecia e segundo a economia disposta pelo Pai; por meio dele foi criado o universo. E no fim dos tempos, para recapitular todas as coisas, [o Verbo] se fez homem entre os homens, visível e tangível, para destruir a morte, para manifestar a vida e restabelecer a comunhão entre Deus e o homem. E como terceiro artigo, o Espírito Santo, de cujo poder os profetas profetizaram, e os Padres foram instruídos com relação a Deus, e os justos foram guiados no caminho da justiça, e que no fim dos tempos foi difundido de um modo novo sobre a humanidade, por toda a terra, renovando o homem para Deus ${ }^{495}$.

Nos diversos símbolos de fé dos Padres da Igreja, poucos argumentos surgem como novidade, o que nos faz intuir que a fé recebida dos apóstolos se conserva inalterada. O bispo de Lião reforça a importância de se "manter inalterada a regra da fé e cumprir os mandamentos de Deus crescendo nele, temendo-o como Senhor, e amando-o como Pai”496, de forma que o cristão esteja sempre disposto a aprofundar-se nessas verdades para beber da água mais pura.

Contudo, qual é a verdadeira fé? Como identificar a diferença entre os ensinamentos falsos e os verdadeiros? Ora, a resposta consiste no fato que a regula veritatis "é a fé que nos mostra tudo o que nos comunicaram os presbíteros, discípulos dos apóstolos. Antes de tudo, a fé nos convida com insistência a recordar que recebemos o batismo"497. Nessa resposta, Irineu apresenta as duas bases fundamentais para garantia da regula fidei: a Tradição apostólica e o que fora recebido no batismo. Ambos os sustentáculos da verdadeira fé estão contidos dentro da comunidade onde for anunciada, compreendida, vivida e testemunhada.

Portanto, segundo G. Laiti, mais do que a necessidade de saber se alguma coisa é ou não verdadeira, o sentimento que o nosso autor demonstra está relacionado à compreensão de que a Igreja é a detentora e a guardiã da fé. De fato, “o Deus dos viventes, anunciado pela Lei, pregado pelos profetas, revelado por Cristo, transmitido pelos apóstolos, crido pela Igreja" ${ }^{498}$ resume bem este binômio entre a regula fidei e a Igreja, entendida como um depósito de grande valor, um vaso sagrado que se renova e renova o vaso que a contém ${ }^{499}$.

Em terceiro e em último lugar, bastante parecido com o conceito precedente, está a compreensão de que o ensinamento apostólico que a Igreja recebeu do

\footnotetext{
${ }^{495}$ IRINEU de Lião, Epideixis 6.

${ }^{496}$ IRINEU de Lião, Epideixis 3.

${ }^{497}$ IRINEU de Lião, Epideixis 3.

${ }^{498}$ IRINEU de Lião, Adversus haereses II, 30, 9.

${ }^{499}$ LAITI, G., La Chiesa nell'economia di Dio secondo Ireneo di Lione, p. 172-173; IRINEU de Lião, Adversus haereses III, 24, 1.
} 
próprio Senhor é a verdadeira gnose difundida pela comunidade eclesial em todo o mundo de maneira aberta, não secreta, visto que "é o caráter distintivo do Corpo de Cristo que consiste na sucessão dos bispos, aos quais foi confiada a Igreja em qualquer lugar ela esteja" ${ }^{, 500}$. Consequentemente, este dom de Deus, que é a verdadeira fé, foi confiado à Igreja ${ }^{501}$, como o sopro de vida inspirado na obra modelada, para que sejam vivificados todos os membros que o recebem. Destarte, "é nela [Igreja] também que foi depositada a comunhão com o Cristo, isto é, o Espírito Santo, penhor de incorrupção, confirmação da nossa fé e escada para subir a Deus" $" 502$.

A regra de fé, para o bispo de Lião, é um instrumento de discernimento entre as verdades de fé e os desvios ensinados pelos gnósticos ${ }^{503}$, que se aplica concretamente por meio do fato de a Igreja ter sido constituída pelo Senhor como luz para iluminar o caminho dos perdidos, cuja "luz" se transforma em pregação verdadeira e firme, que mostra um único e idêntico caminho para a vida verdadeira em Jesus Cristo ${ }^{504}$. A Igreja, sem um anúncio verdadeiro e frutífero, haveria de se tornar uma árvore silvestre, abandonada no deserto. Contudo, pela graça de Deus e pelo enxerto da Verdade e da Vida, conduz todos para o Caminho à vida plena.

\subsubsection{4. \\ A atuação da Igreja}

A partir da análise eclesiológica presente nas obras de Irineu, é possível compreender outra dimensão importante da Igreja: a vivência eclesial em termos de vida cristã ou vida moral. É fundamental no pensamento irineano que a Igreja seja atuante e presente na realidade humana, pois é aí que se percebe o surgimento de uma identidade eclesial de pertença universal e local.

Entende-se por "igreja local" as comunidades espalhadas por todo mundo, que se reúnem em torno da figura do bispo. O bispo de Lião não constrói uma teologia pastoral, do mesmo modo como a entendemos nos tempos hodiernos,

\footnotetext{
${ }^{500}$ IRINEU de Lião, Adversus haereses IV, 33, 8.

${ }^{501}$ IRINEU de Lião, Adversus haereses I, 10, 3; III, 12, 7.

${ }^{502}$ IRINEU de Lião, Adversus haereses III, 24, 1.

${ }^{503}$ IRINEU de Lião, Adversus haereses I, 22, 1.

${ }^{504}$ IRINEU de Lião, Adversus haereses V, 20, 1.
} 
tampouco deixa de apresentar como os cristãos se sentiam impulsionados a estarem presentes em todas as realidades que os cercavam.

A veracidade da pregação e a idoneidade do ensino cristão nascem do testemunho e da vivência clara que os cristãos têm no local onde estão inseridos, pois onde existe algo escondido ou secreto deixa de existir a presença da Igreja de Jesus Cristo.

A pregação apostólica e o ensinamento da Igreja assimilam os deveres morais na vida daqueles que se afastam dos ídolos, da fornicação e da avareza ${ }^{505}$. A conversão, que brota da doutrina e dos ensinamentos, é apresentada como um caminho de cura e uma estrada que conduz para o Reino dos Céus, unindo o homem a Deus ${ }^{506}$. Para tanto, segundo A. Orbe, Irineu faz uso da parábola das núpcias do Cordeiro (Mt 22,1-14; Lc 14,15-24), afirmando que o próprio Senhor enviou seus empregados - apóstolos e discípulos - para convocar todos para a festa de casamento, já que os convidados não tinham aparecido ou não aceitaram a revelação. Todavia, aos que chamou, tanto no tempo presente como no tempo dos profetas, porque se abriram à conversão, Deus concedeu os frutos colhidos na vinha do Senhor - a Igreja -, que passarão pelo lagar - Espírito Santo e batismo que o Senhor construiu, e assim encontrarão a vida verdadeira ${ }^{507}$.

A Igreja que vive segundo os ensinamentos de Cristo é a grande guardiã da Sagrada Escritura ${ }^{508}$, por exercer o zeloso ofício da fidelidade e da integralidade, que conservou o depósito até os dias de Irineu e até os nossos dias.

Nesse sentido, Irineu recorre ao exemplo de Clemente, que em nome da "Igreja de Roma enviou aos coríntios uma carta importantíssima para reuni-los na paz, reavivar-lhes a fé e reconfirmar a Tradição, que há pouco tempo tinham recebido dos apóstolos" ${ }^{\$ 09}$. Visto que mesmo à distância formavam um único Corpo de Cristo, ambas as igrejas - Roma e Corinto - estão presentes nessa única Igreja; assim, o que uma sofre a outra também sente e a vitória alcançada por uma é compartilhada com os irmãos dos outros lugares. Dessa forma, é possível

\footnotetext{
${ }^{505}$ IRINEU de Lião, Epideixis 41.

${ }^{506}$ IRINEU de Lião, Adversus haereses IV, prefácio, 1-2; IRINEU de Lião, Epideixis 1.

${ }^{507}$ IRINEU de Lião, Adversus haereses IV, 36, 5-6; IV, 36, 1-4; ORBE, A., Parábolas evangélicas en San Ireneo, p. 739-745.

${ }_{508}$ IRINEU de Lião, Adversus haereses IV, 24, 1.

${ }^{509}$ IRINEU de Lião, Adversus haereses III, 3, 3.
} 
introduzir o importante tema da oração pelos irmãos, conforme discorre A. G. $\operatorname{Hamman}^{510}$.

São diversas as citações ${ }^{511}$ em que Irineu apresenta a Igreja reunida em oração, em prece, em louvor a Deus e em súplicas. Em muitas ocasiões, Irineu repete que "rezamos para que não permaneçam na fossa que cavaram, convertendo-se à Igreja de Deus, o Cristo seja formado neles, conheçam o Criador e o autor deste universo como único verdadeiro Deus, Senhor de todas as coisas" ${ }^{\text {512 }}$. À oração soma-se a missão de resgatar os que estão presos na mentira, ou seja, não basta descrever uma certeza da verdade dos ensinamentos dos apóstolos presentes na Igreja, mas é necessário que essa verdade possa ser comunicada, para que a graça de Deus transforme os corações dos que estão perdidos.

Irineu argumenta sobre a utilidade da oração, reiterando que a "Igreja é a única a fazer ao Criador esta oblação pura, oferecendo-a com ação de graças por meio de suas mesmas criaturas" ${ }^{„ 513}$, enquanto se ergue em louvor a Deus pelos dons que recebeu generosamente e oferece oblações e sacrifícios puros e agradáveis, não mais como serva, mas na condição de filha de Deus ${ }^{514}$. Aqueles que estão em comunhão dentro dela apresentam a verdadeira oferenda, como o fez Abel, segundo A. Orbe, que estava em paz com Deus e com seu irmão. Por isso, reconhece que Deus o ouve de verdade.

No entanto, aquele que não está em comunhão com o próximo segue o exemplo de Caim, que não acredita que Deus se agradou de suas orações, não alcança a paz em seu coração e assim comete atrocidades ${ }^{515}$. Dessa forma, na oblação está presente a confiança no Senhor, a certeza de que a sua graça está atuando, o gesto que nasce no coração para se materializar em obras concretas, mas sobretudo a necessidade de se expressar na comunhão com o irmão. Logo, em Irineu, a oração abarca não somente a união entre Deus e o ser humano, mas também a vivência fraterna entre os irmãos, até que, juntos, possam chegar a Deus.

\footnotetext{
${ }^{510}$ HAMMAN, A.-G., Saint Irénée et la priére, p. 307-319.

${ }^{511}$ IRINEU de Lião, Adversus haereses III, 25, 7; I, 13, 5; II, 31, 2; III, 12, 5; IV, 19, 1; IV, 17, 6; IV, 18, 1; IV 18, 3-4; IRINEU de Lião, Epideixis 97.

512 IRINEU de Lião, Adversus haereses III, 25, 7.

513 IRINEU de Lião, Adversus haereses IV, 18, 4.

${ }^{514}$ IRINEU de Lião, Adversus haereses IV, 18, 2.

515 IRINEU de Lião, Adversus haereses IV, 18, 3; ORBE, A., Teología de san Ireneo II, p. 246247.
} 
Quando Irineu afirma que Deus “justificou os circuncisos em vista da fé e os incircuncisos pela fé" ${ }^{516}$ - os que vieram antes de Cristo e depois de Cristo -, o tema da justificação não é desenvolvido em função daqueles que creram no Cristo no tempo de sua encarnação, ou em virtude daqueles que confiaram na providência de Deus no tempo dos profetas. Ao contrário, pelo fato de Deus ter elegido a Igreja como sinal no mundo, para os homens de todos os tempos é dado compreender que a justificação vem em função daqueles que "temeram e amaram a Deus, praticaram a justiça e a bondade para com o próximo" "517.

Nesse sentido, de tal maneira a Boa Nova chegou aos seus corações, que puderam ser transformados em novos homens, pela fé, no seu modo de viver e pelas suas atitudes diante do mundo.

Segundo Irineu, outra função importante da Igreja é a capacidade de tornar presente o Corpo e Sangue de $\mathrm{Cristo}^{518}$, por meio do sinal do sacramento, cumprindo a ordem que o próprio Senhor tinha deixado. Mais do que a memória do evento salvífico, segundo J. Aldazábal, para o bispo de Lião, a Eucaristia ${ }^{519}$ é o pão que vem da terra, "ao receber a invocação de Deus, já não é pão comum, mas a Eucaristia, feita de dois elementos, o terreno e o celeste, do mesmo modo em que os nossos corpos, por receberem a Eucaristia, já não são corruptíveis por causa da ressurreição",520.

Dessa forma, o Corpo e o Sangue de Cristo, conforme Scordamaglia, transformam o que é terreno em celestial, ou seja, como o pão se faz carne de Cristo, assim também os homens corruptíveis passam para a vida incorruptível. A oferta do pão e do vinho, juntamente com a oração que a Igreja dirige ao Senhor, fazendo o que Ele mesmo fez, comunica a graça de Deus a todos os que participam do Corpo e do Sangue de Cristo. Em oposição aos marcionitas e gnósticos, Irineu afirma a doutrina eucarística, mostrando-a como ação da Igreja que acolhe a presença real do Senhor, enquanto age por meio do Espírito. Além disso, a Igreja comunica a sua graça aos que dele se alimentam, para que, desse modo, sejam edificados à altura dessa graça ${ }^{521}$.

\footnotetext{
${ }^{516}$ IRINEU de Lião, Adversus haereses IV, 22, 2.

517 IRINEU de Lião, Adversus haereses IV, 22, 2.

518 IRINEU de Lião, Adversus haereses IV, 18, 5; V, 2, 2-3.

519 ALDAZÁBAL, J., A Eucaristia, p. 146-149.

520 IRINEU de Lião, Adversus haereses IV, 18, 5.

${ }^{521}$ SCORDAMAGLIA, D., Ritratti di Cristo in sant'Ireneo, p. 194-198; ORBE, A., Teología de san Ireneo IV, p. 255-258.
} 
Ademais, a perseguição e o martírio são características inerentes à Igreja peregrina neste mundo, que reúne os que receberam o Espírito de Deus e testemunha em seus filhos a obediência ao Verbo do Pai e a entrega total, por meio daquele serviço prestado quando o mártir persevera enquanto sofre perseguições, enquanto é levado para ser apedrejado e, em última análise, enquanto está sendo martirizado ${ }^{522}$.

A presença profética da Igreja ${ }^{523}$ no mundo a leva a denunciar as mentiras e os erros, proclamando, assim, a verdade como único fundamento da existência humana e única forma de produzir frutos para vida verdadeira ${ }^{524}$. A Igreja "sofre perseguição pela justiça, sofre toda espécie de tormentos, e são mortos pelo amor de Deus; continuamente mutilada, logo aumenta os seus membros e readquire a integridade" ${ }^{\mathrm{N} 25}$.

Outro aspecto da metáfora da Igreja à luz do texto sobre a mulher de $\operatorname{Lot}^{526}$, transformada em estátua de sal, como dito acima, conforme G. Jossa, revela como a Igreja perde parte do seu sal para dar sabor à vida de tantos que estavam perdidos no erro e na perdição, recuperando-se mais à frente para acolher novos filhos e os conduzir ao Senhor. "Eis por que a Igreja, no seu amor por Deus, em

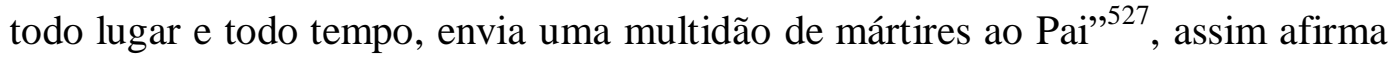
o bispo de Lião, para contrapor os gnósticos que defendiam que não era necessário um testemunho tão explícito e rigoroso de fé, como aquele vivido pelos mártires.

Irineu argumenta, segundo E. Osborn, que o martírio é fruto da luta do ser humano contra toda escravidão do erro e da mentira, diante da liberdade que o Espírito de Deus concede àqueles que descobrem o Caminho, a Verdade e a $\operatorname{Vida}^{528}$. Essa fidelidade irrestrita ao Senhor conduz à liberdade verdadeira, para que possam saborear o gosto da verdadeira vida. Por isso, quando a Igreja envia os mártires ao Senhor, ela não perde os seus membros, mas cumpre neste mundo a sua missão de conduzir todos ao encontro do Senhor.

\footnotetext{
522 IRINEU de Lião, Adversus haereses IV, 33, 10.

${ }^{523}$ IRINEU de Lião, Adversus haereses I, 13, 4; III, 17, 1.

${ }^{524}$ IRINEU de Lião, Adversus haereses IV, 4, 1.

525 IRINEU de Lião, Adversus haereses IV, 33, 9.

${ }^{526}$ JOSSA, G., Regno di Dio e chiesa, p. 204-205.

${ }^{527}$ IRINEU de Lião, Adversus haereses IV, 33, 9.

${ }^{528}$ OSBORN, E., Irenaeus of Lyons, p. 241-242; IRINEU de Lião, Adversus haereses V, $24,4$.
} 


\subsubsection{5.}

\section{A Tradição Apostólica}

Um tema muito caro a Irineu é a Tradição Apostólica. Para o bispo de Lião essa Tradição é tão fundamental que precede em importância as Escrituras Sagradas, quando se impõe como a referência de autoridade mais imediata, por ter sido recebida dos apóstolos, compreendidos como doze fontes que brotaram no deserto onde Deus fundou e alicerçou a sua Igreja. Pelo testemunho dos apóstolos, é possível afirmar a regula fidei e refutar os hereges, para se alcançar a verdadeira gnose.

Ocorre aqui entender a diferença que existe entre a regula fidei e a Tradição apostólica, complementando aquilo que já foi explicado anteriormente. A regula fidei - ou regula veritatis - às vezes se apresenta na mesma linha de um símbolo de fé, conforme S. Barbaglia, professado oralmente pela comunidade e, às vezes, adquire a forma textual em que a fé cristã é declinada num conjunto de conceitos e frases, mais elaborados que o símbolo.

Em Irineu, a regula fidei é de fundamental importância para a interpretação das Sagradas Escrituras e também para uso interno da Igreja. Ela é a norma para se entender a fé, ao mesmo tempo que é a norma de fé. Nela está o conjunto das verdades que se crê, ensina, anuncia e compreende ${ }^{529}$.

Já a Tradição apostólica, segundo J. Fantino, é indicada como um critério de autoridade para a comunidade cristã ${ }^{530}$, ou seja, é aquilo que dava fundamento e autenticidade para o modo de vida dos cristãos. Irineu usa esse termo para se distanciar das tradições que os grupos gnósticos defendiam. Segundo o bispo de Lião, os gnósticos não tinham autenticidade nas suas tradições, pois promoviam as suas fábulas em mosaicos desfigurados, sem conhecer a imagem verdadeira da revelação divina. Em contrapartida, conforme V. Grossi, os cristãos, mesmo espalhados pelo mundo, conservaram a verdade nos costumes, nas celebrações, nos ritos e nos ensinamentos, pois a herdaram dos que realmente eram a fonte primeira, isto é, dos apóstolos, como testemunhas oculares do que Jesus fez, falou e viveu ${ }^{531}$.

${ }^{529}$ GROSSI, V., Linee di ecclesiologia patrística, p. 18-19; BARBAGLIA, S., Ireneo di Lione e la comunicazione della fede cristiana, p. 87-90.

${ }^{530}$ FANTINO, J., La théologie d'Irénée, p. 29-34.

${ }^{531}$ GROSSI, V., Linee di ecclesiologia patrística, p. 27; IRINEU de Lião, Adversus haereses, I, 8, 1. 
Sendo assim, para Irineu é claro que a Igreja, dispersa pelo mundo inteiro, recebeu dos apóstolos esta Tradição ${ }^{532}$. E ele se utiliza da perícope do rio de água que Deus fez brotar em abundância no deserto (Ex 17,6; Nm 20,7-13), produzindo doze fontes, ou seja, a doutrina dos doze apóstolos ${ }^{533}$, para justificar que a fonte desta Tradição é o próprio Deus. Por meio deles, a verdade se torna manifesta e facilmente pode ser encontrada na Igreja, "porque os apóstolos trouxeram, como num rico celeiro, tudo o que pertence à verdade, a fim de que cada um que o deseje encontre aí a bebida da vida, o caminho de acesso à vida"534.

Por conseguinte, a Igreja guarda e conserva esta verdade, pois a normatividade, os costumes, as celebrações, os ritos foram surgindo daquilo que os apóstolos colheram do Senhor, em sua encarnação, e do que se foi vivendo e praticando nas primeiras comunidades. Portanto, a Tradição apostólica é o princípio que rege e regulamenta a vida cristã e as comunidades, o que para Irineu é fundamental, na medida em que possibilita mostrar, dentro do cristianismo, qual seja a diferença entre os grupos gnósticos e as verdadeiras comunidades cristãs.

Ao iniciar o terceiro livro da Adversus haereses - no qual Irineu trata da doutrina cristã -, o autor, conforme A. Benoit, conscientiza seu "caríssimo amigo" sobre os que buscam, a partir de uma dita sabedoria que vem do alto, as verdades mais profundas e escondidas, que os apóstolos e presbíteros da Igreja não teriam capacidade de compreender, respaldados pelo próprio apóstolo Paulo, que se refere a uma sabedoria pregada entre perfeitos, e que não vem deste mundo (1Cor $2,7)^{535}$.

Para defender a verdade, segundo Y. Andia, Irineu diz que "quando, por nossa vez, os levamos à Tradição que vem dos apóstolos e que é conservada nas várias igrejas, pela sucessão dos presbíteros" ${ }^{, 536}$, ou seja, não somente os conduz às Sagradas Escrituras, mas sim à "única fé, verdadeira e vivificante, que a Igreja recebeu dos apóstolos e comunica a seus filhos" ${ }^{\text {} 537}$, os hereges não aceitam e nem dão crédito, pois se colocam além dessa Tradição. Sendo assim, Irineu dirá que eles são ladrões e assaltantes, que não estão em comunhão com a verdadeira

\footnotetext{
${ }^{532}$ IRINEU de Lião, Adversus haereses II, 9, 1.

${ }^{533}$ IRINEU de Lião, Epideixis 46.

${ }^{534}$ IRINEU de Lião, Adversus haereses III, 4, 1.

${ }^{535}$ BENOIT, A., Ecriture et Tradition chez saint Irénée, p. 35-37.

${ }^{536}$ IRINEU de Lião, Adversus haereses III, 2, 2.

${ }^{537}$ IRINEU de Lião, Adversus haereses III, prefácio.
} 
Tradição $^{538}$, inventando mentiras e distorcendo os textos, para apresentarem um conhecimento que, embora superior e elevado, seja desprovido de base que o fundamente e dê garantia ${ }^{539}$.

Além disso, conforme S. Barbaglia, o bispo de Lião convida o seu leitor a recordar que "o Senhor de todas as coisas deu aos seus apóstolos o poder de pregar o evangelho e por meio deles nós conhecemos a verdade, isto é, o ensinamento do Filho de Deus" ${ }^{, 540}$. Irineu admoesta o seu leitor sobre a importância de reconhecer nos apóstolos um testemunho veraz e um ensinamento claro, firme e que venha de homens que nada ocultaram, que nunca ensinaram em particular o que fosse diverso do que deviam ensinar em público ${ }^{541}$.

A Tradição é tão importante que envolve toda a Igreja desde os tempos apostólicos até os tempos atuais. Nesse sentido, a fidelidade dos apóstolos ao Senhor, como nos transmitem as Escrituras, e o testemunho que eles deixaram ${ }^{542}$, constituíram as bases das comunidades cristãs que conservaram essa Tradição pelos séculos ${ }^{543}$. "A Igreja dispersa pelo mundo inteiro recebeu dos apóstolos esta Tradição"544, o que significa dizer que "a Tradição apostólica se apresenta na Igreja e perdura entre nós" ${ }^{, 545}$.

Enfim, Irineu colocou em evidência o modo com o qual os apóstolos sempre confessaram o Senhor e Deus, o Criador do céu e da terra. Fez isso considerando o desenvolvimento histórico pelo qual Deus tinha orientado o seu povo, por meio dos seus líderes, conversando outrora com Moisés, enquanto estabelecia a economia da Lei. Também chamou os patriarcas, até que dirigisse diretamente os seus ensinamentos aos mesmos apóstolos e discípulos de Cristo.

\footnotetext{
${ }^{538}$ IRINEU de Lião, Adversus haereses III, 15, 1.

539 ANDIA, Y. L'hérésie et as refutation selon Irénée de Lyon, p. 635-640; IRINEU de Lião, Adversus haereses IV, 33, 8 .

${ }^{540}$ IRINEU de Lião, Adversus haereses III, prefácio.

${ }^{541}$ BARBAGLIA, S., Ireneo di Lione e la comunicazione della fede cristiana, p. 129-140; IRINEU de Lião, Adversus haereses III, 15, 1.

${ }^{542}$ IRINEU de Lião, Epideixis 86.

543 BENOIT, A., Ecriture et Tradition chez saint Irénée, p. 39-41; IRINEU de Lião, Adversus haereses III, 2, 2.

544 IRINEU de Lião, Adversus haereses II, 9, 1.

${ }^{545}$ IRINEU de Lião, Adversus haereses III, 5, 1.
} 
3.2.2.6.

A sucessão apostólica e os ministérios

Em Irineu de Lião, a sucessão apostólica não apresenta somente uma sequência de bispos que assumiram as igrejas, mas, na verdade, remete à importância da conservação da Tradição apostólica. Esta sucessão, segundo J. Fantino, garante a credibilidade da fé e da Tradição, que por sua vez se desenvolve nas igrejas locais ${ }^{546}$. Ao argumentar sobre a sucessão apostólica, Irineu apresenta uma reflexão sobre como os bispos assumem e são responsáveis pelas igrejas, mas também fala sobre os presbíteros que conservam tal Tradição e, ainda, estende o conceito à presença e à atuação dos diáconos.

No século II da era cristã, os ministérios não estão estabelecidos de uma maneira uniforme na Igreja, nem o processo de formação de um ministério hierárquico é claro, como é de se notar nas cartas de Inácio de Antioquia, por exemplo. Contudo, é possível perceber, pelo número de vezes que o bispo de Lião se refere aos demais bispos, aos presbíteros e aos diáconos, que sua presença entre os membros do povo de Deus e sua relação com a vida eclesial já são notórias para a sensibilidade de um autor preocupado em demonstrar a autoridade dos diversos ministérios na Igreja ${ }^{547}$.

L. Spikowski apresenta outra perspectiva da teologia de Irineu sobre o ministério episcopal, pois afirma não somente o episcopado hierárquico já no final do século II, como, ainda, apresenta os bispos como doutores e governantes estáticos de suas igrejas ${ }^{548}$. Essa proposta se contrapõe às próprias atitudes descritas por Irineu na sua obra, já que narra ter ido a Roma duas vezes, como bispo da Gália, para acertar questões sobre a data da Páscoa. Ele assumiu, assim, a missão de embaixador da paz entre as igrejas do Oriente e a igreja de Roma, reforçando a perspectiva de um ministério episcopal itinerante, segundo A. Orbe e H. Ribeiro, citados acima.

Para Irineu, segundo E. Osborn, a relação entre sucessão apostólica e Tradição se traduz pela atestação universal dos bispos, cujo caminho de autoridade em cada lugar pode ser refeito, até se chegar à atividade dos apóstolos

\footnotetext{
${ }^{546}$ FANTINO, J., La théologie d'Irénée, p. 35-38.

${ }^{547}$ FANTINO, J., La théologie d'Irénée, p. 43-45.

${ }^{548}$ SPIKOWSKI, L., La doctrine de l'église dans saint Irénée, p. 69-75.
} 
e dos seus primeiros sucessores ${ }^{549}$. Com isso, a sucessão apostólica garante a verdade da fé ensinada, a perfeição nos costumes e na forma de vida, exigindo dos mesmos sucessores que perseverem em dar testemunho absoluto de perfeição e irrepreensibilidade, para serem de grande valia em tudo na evangelização, nas palavras, na pregação e, enfim, na vivência dos costumes cristãos ${ }^{550}$.

O conceito de sucessão apostólica não é uma novidade no Novo Testamento, pois, já no Antigo Testamento, Deus tinha constituído o sacerdote Aarão e toda a sua estirpe, descendentes de Levi, para servirem ao Senhor no santuário ${ }^{551}$. Como esse santuário é figura e representação da Igreja, na opinião de Irineu, a sucessão apostólica nasce desse mesmo chamado sacerdotal. "Todos os discípulos do Senhor são sacerdotes, eles que aqui não têm nem campos nem casa em herança, mas servem sempre ao altar e a Deus ${ }^{\text {"552 }}$. Ou seja, pertencem por comparação aos descendentes de Levi, que cumpriam a missão sacerdotal e não tinham herança, já que a sua herança era o Senhor. E da mesma forma que "em terra estrangeira nasciam as doze tribos, os filhos de Israel, porque também o Cristo devia gerar em terra estrangeira as doze colunas, fundamento da Igreja" ${ }^{253}$. A sucessão oriunda dos apóstolos constrói o grande edifício do Senhor, que é a Igreja.

Para reafirmar, conforme D. Singles, a importância dessa sucessão como garantia da verdade e da fé, Irineu apresenta a primeira lista de sucessores dos apóstolos Pedro e Paulo na igreja de Roma, como modelo e protótipo de todas as outras igrejas, e ressalta a excelência da "maior e mais antiga e conhecida por todos" ${ }^{\text {554. }}$ Qualquer outra igreja "deve necessariamente estar de acordo com ela, por causa da sua origem mais excelente" ${ }^{\natural 55}$. Desta maneira, o que ali aconteceu e acontece torna-se modelo de conduta e norma de organização para os demais cristãos espalhados pelo mundo ${ }^{556}$.

A lista de sucessores é extensa e relata muitos bispos com peculiaridades de informação, mas o detalhe principal se encontra ao término da lista, em que Irineu afirma que, com aquela ordem e sucessão, tinha chegado até o seu tempo e o

\footnotetext{
${ }^{549}$ IRINEU de Lião, Adversus haereses III, 3, 1.

${ }^{550}$ OSBORN, E., Irenaeus of Lyons, p. 86;146-148.

${ }^{551}$ IRINEU de Lião, Epideixis 26.

${ }^{552}$ IRINEU de Lião, Adversus haereses IV, 8, 3.

${ }^{553}$ IRINEU de Lião, Adversus haereses IV, 21, 3.

${ }^{554}$ IRINEU de Lião, Adversus haereses III, 3, 2.

555 IRINEU de Lião, Adversus haereses III, 3, 2.

${ }^{556}$ SINGLES, D., A glória de Deus é o homem vivo, p. 147-152.
} 
ministério episcopal que ele recebeu da Igreja, ou seja, a Tradição apostólica e a pregação da verdade ${ }^{557}$. Mais um testemunho claro do bispo de Lião sobre a relação entre sucessão apostólica e Tradição.

Em outra ocasião, ao relatar a visita de Policarpo, "que, pelos próprios apóstolos, foi estabelecido bispo na Ásia, na igreja de Esmirna"558, a Aniceto, bispo de Roma, a fim de que discutissem as questões em torno da data da celebração da Páscoa do Senhor, Irineu entende que o diálogo e a colegialidade entre os dois manifestava a importância da paz entre os irmãos e a verdade da fé.

É provável que Irineu tenha acompanhado Policarpo em sua visita à igreja de Roma. De fato, todos descendiam, no batismo, de um único Senhor ${ }^{559}$ e é dele que todos receberam o chamado a serem: apóstolos, epíscopos, presbíteros ${ }^{560}$, doutores, diáconos, diaconisas, profetas. "Onde foram postos os carismas do Senhor, ali se deve aprender a verdade, junto dos que na Igreja possuem a Sucessão dos apóstolos, a integridade inatacável da conduta e a pureza incorruptível da palavra" ${ }^{, 561}$.

A sucessão apostólica e a Tradição, de acordo com D. Singles, se unem na perspectiva de irmãos que se preocupam com a edificação mútua. Os gnósticos e outros hereges não podem reivindicar uma linha sucessória para os seus grupos, pois, como dizem, sua origem é divina. Já na tradição cristã, o batismo garante, espiritual e fisicamente, a unidade com o Cristo; a Sagrada Escritura documenta o verdadeiro ensinamento; e a sucessão apostólica sustenta a Igreja no caminho do Senhor ${ }^{562}$.

Dessa forma, segundo V. Grossi e A. Di Berardino, a sucessão apostólica é critério de desconfiança em relação às tendências emancipatórias daqueles que se apresentam com doutrinas que não pertencem à linha dos apóstolos, quase sempre com interesses que promovem cisma, orgulho, lucro e vanglória ${ }^{563}$.

\footnotetext{
${ }^{557}$ IRINEU de Lião, Adversus haereses III, 3, 3.

${ }^{558}$ IRINEU de Lião, Adversus haereses III, 3, 4.

${ }^{559}$ IRINEU de Lião, Adversus haereses IV, 26, 2.

${ }^{560}$ IRINEU de Lião, Adversus haereses III, 2, 2; IV, 32, 1; IRINEU de Lião, Epideixis 3.

${ }^{561}$ IRINEU de Lião, Adversus haereses IV, 26, 5.

562 SINGLES, D., A glória de Deus é o homem vivo, p. 146-147; FANTINO, J., La théologie d'Irénée, p. 38-49.

${ }^{563}$ IRINEU de Lião, Adversus haereses IV, 26, 2; GROSSI, V.; DI BERARDINO, A., La chiesa antica, p. 123.
} 


\subsubsection{7.}

\section{A Virgem Maria no mistério da recapitulação de Jesus Cristo}

A figura da Virgem, como Irineu se remete a ela na maioria das vezes, aparece em destaque em todo o conjunto da obra irineana, sendo possível perceber a sua participação no mistério da recapitulação de Jesus Cristo. Ao se fazer obediente ao Senhor, segundo D. Singles, Maria acolhe a encarnação do Verbo, Filho de Deus, em seu seio, e abre, assim, as portas para o processo inverso daquilo que Eva e Adão fizeram. Portanto, ela conduz a humanidade, decaída no pecado das origens, à regeneração em Cristo Jesus. Na teologia irineana, a Virgem Maria tem um lugar importante na obra da salvação, e ele será o primeiro autor na patrística a elevá-la a um grau tão singular ${ }^{564}$.

Além das citações referentes à Virgem Maria, em virtude da encarnação de Jesus Cristo e do cumprimento das profecias do Antigo Testamento, Irineu apresenta Maria como a Mãe de Jesus, destacando que, diferentemente dos gnósticos, que diziam que Jesus "passou por Maria como a água passa por tubo ${ }^{, 565}$, o Verbo de Deus se formou no seio de Maria e recebeu dela o necessário para que a vida humana pudesse existir. Irineu também cita Maria como imagem da Igreja, considerando-a como aquela que está presente na ação e na vida eclesial. Além disso, por meio de Maria, Deus integra Jesus Cristo à promessa feita a Abraão e à estirpe de Davi.

A começar pelas várias menções à Mãe de Deus ${ }^{566}$, antes das definições conciliares dos séculos IV e V, o bispo de Lião já rascunha uma teologia segundo a qual a afirmação da maternidade de Maria tem a ver com a filiação divina de Cristo. Ele mesmo a sustenta, ao relatar a pregação de Pedro na casa de Cornélio, na qual "o próprio Jesus é o Filho de Deus... por ter recebido a unção do Espírito Santo; é chamado Jesus Cristo, e é o mesmo que nasceu de Maria"567. Ou seja, defende a fé em Cristo, segundo G. Jossa, contra os grupos gnósticos que ora negavam a sua humanidade, ora negavam a sua divindade.

De fato, Irineu amplifica seus argumentos, afirmando que "o evangelho não conhece, pois, nenhum outro Filho do homem senão o que nasceu de Maria"568, e

\footnotetext{
${ }^{564}$ SINGLES, D., A glória de Deus é o homem vivo, p. 66.

${ }^{565}$ IRINEU de Lião, Adversus haereses I, 7, 2.

${ }^{566}$ IRINEU de Lião, Adversus haereses III, 16, 5; III, 23, 7; IV, 9, 2; V, 1, 3.

${ }^{567}$ IRINEU de Lião, Adversus haereses III, 12, 7.

568 JOSSA, G., Regno di Dio e Chiesa, p. 110-111; IRINEU de Lião, Adversus haereses III, 16, 5.
} 
que Ele é o que Deus prometeu enviar, segundo os patriarcas, profetas e sábios do Antigo Testamento, "da descendência de Davi pela concepção que teve de Maria, predestinado a ser Filho de Deus, Jesus Cristo, pelo seu poder, por meio do Espírito de santidade" ${ }^{, 56}$.

O bispo de Lião ainda confirma essa argumentação dizendo que Jesus Cristo, Filho de Deus, foi predito por Moisés e com ele conversou. Além disso, "veio à Judéia, gerado por Maria, que era da estirpe de Davi e de Abraão" 570 . Logo, Maria resgata o chamado original que Deus tinha feito a Abraão, para ser o pai de um grande povo, ao se tornar a geradora, pela graça de Deus, do Cristo para o mundo.

No seu projeto de combater os hereges, segundo J. Behr, Irineu argumenta que a maternidade de Maria questiona a estultice dos discípulos de Valentim, que insistiam em afirmar "que Ele se manifestou somente de maneira aparente" heresia conhecida como docetismo - e "os ebionitas que se recusam a admitir nas suas almas, pela fé, a união de Deus com o homem e permanecem no velho fermento de seu nascimento"572 - que futuramente será desenvolvida pelo arianismo e por outras heresias cristológicas.

Em nome do dualismo, os gnósticos não aceitavam a encarnação de Jesus. Por isso, Irineu apresenta uma importante definição de fé cristã, que confirma o nascimento de Cristo, oriundo da Virgem, como sinal do resgate da humanidade:

eles não querem entender que o Espírito Santo sobreveio em Maria e que o poder do Altíssimo a cobriu com sua sombra e que, por isso, quem nasceu dela é o Filho de Deus Altíssimo, o Pai de todas as coisas, que operou a encarnação de seu Filho, fazendo aparecer um novo nascimento, a fim de que, tendo nós herdado a morte pelo nascimento anterior, por este, herdássemos a vida ${ }^{573}$.

Consequentemente, Irineu também relaciona a concepção virginal de Maria com a ação de Deus em José ${ }^{574}$. Foi assim que ele pôde compreender os desígnios que Deus realizava, para acolhê-los com generosidade. Desse modo, o anjo lhe transmitiu as palavras do profeta, a fim de que ele se convencesse de que Maria era a Virgem que Isaías preanunciara como a mãe do Emanuel.

\footnotetext{
${ }^{569}$ IRINEU de Lião, Adversus haereses III, 16, 3.

${ }^{570}$ IRINEU de Lião, Epideixis 40.

${ }^{571}$ IRINEU de Lião, Adversus haereses V, 1, 2.

572 IRINEU de Lião, Adversus haereses V, 1, 3.

${ }^{573}$ IRINEU de Lião, Adversus haereses V, 1, 3; BEHR, J., Irenaeus of Lyons, p. 150-151.

${ }^{574}$ IRINEU de Lião, Adversus haereses IV, 23, 1.
} 
A virgindade de Maria é uma constante na obra do bispo de Lião, com muitas referências ${ }^{575}$ à missão que Maria recebe de Deus: "o Senhor mesmo deu o sinal da Virgem, ou seja, o Emanuel, nascido da Virgem, e alegra os ânimos daqueles que o bebem ${ }^{576}$, ou seja, daqueles que recebem o seu Espírito, alegria eterna" ${ }^{577}$.

O sinal da Virgem é o sinal do broto novo ${ }^{578}$, que nasce no tronco de Israel, da raiz de Jessé, que não é somente uma descendência, mas sim um sinal da fé que ressurge no povo, formando o novo povo de Deus. O Senhor não desistiu do seu povo, como prometera a Noé no dilúvio, mas apresentou a nova estirpe que ressurgirá daqueles que creem na ação de Deus pela concepção virginal e na graça da nova vida que o Filho de Maria vem trazer pelo Espírito Santo.

A promessa de Deus se cumpre de forma plena e definitiva, pois o "Rei é o Cristo, o Filho de Deus tornado Filho do homem, isto é, nascido, como fruto, da Virgem da descendência davídica" ${ }^{, 579}$, porque Deus estabelece seu Reino único e definitivo, tendo seu Filho como Rei e Senhor, para pertencer ao seu Povo, onde todos poderão ouvir a voz do Senhor, seguindo os passos do Messias feito homem e abrindo-se à graça de uma nova vida, que nasce na água e no Espírito.

Para dar início a esse novo povo ${ }^{580}$, Deus se utiliza, segundo Irineu, de dois eventos extraordinários: "como o inesperado era a salvação que se devia realizar para os homens, pelo socorro de Deus, inesperado também devia ser uma Virgem dar à luz um filho, como sinal de Deus e não por obra de homem" ${ }^{\text {,51 }}$. Não é mais um arco-íris no céu, não são mais as tábuas da Lei, não é mais a tenda da reunião; o sinal, agora, é o Filho, um homem, nascido como todos os homens, mas oriundo de uma Virgem, para sinalizar a epifania da graça de Deus. E não é apenas um sinal, nem um pedido, nem tampouco um evento esperado; mas os que tiverem o

${ }^{575}$ IRINEU de Lião, Epideixis 35-39; 53-54; 57; 59; 63; Adversus haereses I, 10, 1; III, 4, 2; III, 9 , 2; III, 16, 2-5; III, 18, 3; III, 18, 7; III, 19, 1-3; III, 20, 3; III, 21, 1; III, 21, 4-6; III, 22 , 1.

${ }^{576}$ Irineu remete à Gn 49,10-11, na qual Deus promete dar a Israel sempre um rei ou príncipe que governará seu Povo, e ele "lava sua roupa no vinho, seu manto no sangue das uvas", no qual Irineu interpreta que lavar a roupa no vinho é crer em Jesus, na salvação que Ele trouxe por meio do derramamento do seu Sangue, e o sangue da uva que se bebe remete a ação divina, pois não foi o homem quem fez a uva, mas veio da natureza, como o Corpo e Sangue de Cristo, que não é realidade humana, mas divina.

577 IRINEU de Lião, Epideixis 57.

578 IRINEU de Lião, Epideixis 59.

${ }^{579}$ IRINEU de Lião, Epideixis 36.

${ }^{580}$ IRINEU de Lião, Adversus haereses III, 21, 4.

${ }^{581}$ IRINEU de Lião, Adversus haereses III, 21, 6; PLAGNIEUX, J., La doctrine mariale de saint Irénée, p. 185. 
coração aberto verão o que os olhos não viram e compreenderão o que nenhuma mente humana imaginou ${ }^{582}$.

Então, qual é o sinal que Deus envia? "A sedução de que foi vítima, miseravelmente, a virgem Eva, destinada a varão, foi desfeita pela Boa Nova da verdade, maravilhosamente anunciada pelo anjo à Virgem Maria, já desposada a varão"583. O sinal da Virgem, apresentado por Irineu, segundo B. Sesboüé, estabelece um paralelismo antitético entre Eva e Maria ${ }^{584}$, ambas prometidas aos seus esposos, o que leva Irineu a reforçar a identidade de serem virgens e terem atitudes diversas: uma se abre ao pecado, à tentação, e, assim, a morte entra na humanidade; a outra se abre à voz de Deus, por meio do anúncio do anjo Gabriel, aderindo à vontade do Senhor ${ }^{585}$.

A obediência de Maria ao chamado de Deus faz dela advogada de Eva, segundo Irineu, já que não soube estar atenta à palavra do Senhor e acabou se perdendo, por não viver o mandamento do Senhor. Em relação à Virgem Maria, "pela sua obediência se tornou para si e para todo o gênero humano causa da salvação" 586 . Por isso, "o nó da desobediência de Eva foi desatado pela obediência de Maria, e o que Eva amarrou pela sua incredulidade, Maria soltou pela sua fé" 587 .

Irineu estabelece um caminho de recirculatio, ou seja, de Eva para Maria há um caminho de degeneração e de desobediência, que levou a humanidade a rejeitar o Criador de todas as coisas, desobedecendo a sua voz e abandonando os seus preceitos. Porém, de Maria a Eva há um caminho de regeneração e de obediência, no qual o Verbo de Deus se fez homem e veio habitar na criação, para mostrar a todos o amor e o poder de Deus. "Por causa de uma Virgem obediente à Palavra de Deus, [o homem] foi ressuscitado e recobrou a vida" ${ }^{\text {}}$, .

Irineu, então, segundo A. Orbe, apresenta a Virgem Maria como partícipe da recapitulação que Jesus Cristo, Filho de Deus, realiza. "Como pela desobediência de um só homem o pecado entrou no mundo e, pelo pecado, a morte, assim pela

\footnotetext{
582 IRINEU de Lião, Adversus haereses III, 19, 2-3.

${ }^{583}$ IRINEU de Lião, Adversus haereses V, 19, 1.

${ }^{584}$ Esta comparação entre Eva e Maria é comum na patrística, o primeiro autor a fazer referência é Justino de Roma, Diálogo com Trifão 100, 5.

${ }^{585}$ ORBE, A., Teología de san Ireneo II, p. 258-265.

${ }^{586}$ IRINEU de Lião, Adversus haereses III, 22, 4.

${ }^{587}$ IRINEU de Lião, Adversus haereses III, 22, 4; BEHR, J., Irenaeus of Lyons, p. 174-175.

${ }^{588}$ IRINEU de Lião, Epideixis 33; SESBOÜÉ, B., Tout récapituler dans le Christ, p. 143-145.
} 
obediência de um só homem foi introduzida a justiça que traz como fruto a vida ao homem morto",589.

Parafraseando Rm 5,18-19, Irineu apresenta o caminho da recapitulação que Deus realizou na humanidade por meio de seu Filho. Se o tentador usou daquele que Deus havia modelado da terra virgem - pois o Criador não havia feito chover sobre a terra - para executar a sua obra, "assim o Verbo que recapitula Adão em si, recebeu de Maria, ainda virgem, a geração da recapitulação de Adão",590.

Em função disso, não poderia o Criador ter modelado no limbo da terra um novo homem para recapitular a humanidade, ao invés de uma geração no seio virginal de Maria? "Para que não houvesse segunda obra modelada e para que não fosse a obra modelada diferente da que era salva, mas, conservando a semelhança, fosse aquela primeira a ser recapitulada" ${ }^{„ 591}$. Sendo assim, a recapitulação não é um abandono da criação e um novo início, mas um processo de regeneração do que se perdera, pois Deus mesmo modelou com suas mãos - o Filho e o Espírito a criação, e "é por meio deles e neles que fez todas as coisas, soberanamente e com toda liberdade, e é a eles que se dirige" ${ }^{, 592}$.

Para não abandonar a obra de suas mãos, Deus quis unir "o Verbo de Deus com a criatura modelada por Ele, isto é, que o Verbo se faria carne, e o Filho de Deus, Filho do homem"593, numa união em que nasceria o Emanuel - Deus conosco - apresentado pelos profetas. Em tal nascimento, os homens já são regenerados em Deus; tendo-se feito aquilo mesmo que nós somos, não deixa de ser o Deus forte que possui origem inexprimível ${ }^{594}$.

Irineu resgata, conforme J. Aldama, a fala de Deus a Adão e Eva: "Porei inimizade entre ti e a mulher e entre tua descendência e a dela; esta te esmagará a cabeça e tu lhe ferirás o calcanhar" (Gn 3,15), para mostrar que "desde esse momento... foi anunciado que esmagaria a cabeça da serpente aquele, semelhante a Adão, que devia nascer de Virgem" ${ }^{\text {595 }}$. O que pisa a cabeça da serpente é o nascido de Maria, "Virgem por vontade e sabedoria de Deus"596, pois Cristo

\footnotetext{
${ }^{589}$ IRINEU de Lião, Adversus haereses III, 21, 10.

${ }^{590}$ IRINEU de Lião, Adversus haereses III, 21, 10.

${ }^{591}$ IRINEU de Lião, Adversus haereses III, 21, 10.

592 ORBE, A., Introduccion a la teologia de los siglos II y III, p. 311-317; IRINEU de Lião, Adversus haereses IV, 20, 1.

${ }^{593}$ IRINEU de Lião, Adversus haereses IV, 33, 11.

${ }^{594}$ IRINEU de Lião, Adversus haereses IV, 33, 11.

${ }^{595}$ IRINEU de Lião, Adversus haereses V, 21, 1.

${ }^{596}$ IRINEU de Lião, Epideixis 32.
} 
recapitulou em si esse homem, princípio do gênero humano. Ademais, reproduziu o mesmo esquema de corporeidade, para demonstrar a identidade da sua corporeidade com a de Adão e conosco. Assim, a salvação atingiu todo ser humano criado 597 .

Desta forma, Irineu afirma que Maria, ao cantar as maravilhas de Deus em sua vida, cantava profeticamente, em nome da Igreja: "A minha alma glorifica o Senhor e meu espírito exulta em Deus, meu Salvador. Socorreu Israel, seu servo, lembrando de sua misericórdia, conforme prometera aos nossos pais, em favor de Abraão e de sua descendência, para sempre" (Lc 1,46-47). Com palavras de tanta importância, o evangelho mostra o fato de Deus ter falado aos pais, isto é, ter dado a Lei por meio de Moisés, infundindo sobre nós a sua misericórdia ${ }^{598}$.

Nesse sentido, a Igreja se forma pelos que foram resgatados no Filho de Deus. O novo povo de Deus nasce dessa recapitulação e em Maria encontra o modelo da discípula atenta à Palavra do Senhor, obediente ao seu chamado, sempre pronta a dizer seu "sim" de vida; não para si, mas para a humanidade da qual ela se torna Mãe.

Neste terceiro capítulo, a ortodoxia de Irineu presente na suas duas obras Adversus haereses e Epideixis, possibilitou a explanação sobre a gnose valentiniana e a sua hierarquia nas emanações, separando-as por importância na ordem que foram surgindo, porém, não é possível compreender o sistema gnóstico fora de um contexto eclesiológico claro e definido. Sendo assim, o termo Igreja, a hierarquia dos éons e a própria gnose como produto doutrinal de conhecimento designam, quer porque dependa do cristianismo, quer porque faz o cristianismo depender dela, os mais antigos conceitos ligados à eclesiologia desse grupo.

Em sequência, examinou-se o pensamento de Irineu sobre a Igreja, o qual a afirma como obra de Deus, que, no mistério insondável do seu amor de Pai pelo ser humano criado, envia o Filho, Jesus Cristo, para recapitular a criação, para resgatar o homem decaído e restituir-lhe a dignidade de filho por meio da adoção em Cristo. Sendo assim, a encarnação do Filho de Deus marca o início da Igreja que tem em Cristo seu grande modelo, enquanto ela é conduzida e guiada pelo

\footnotetext{
${ }^{597}$ ALDAMA, J., María en la patrística de los siglos I y II, p. 300-305; ORBE, A., Teología de san Ireneo VI, p. 465-466.

${ }^{598}$ IRINEU de Lião, Adversus haereses III, 10, 2.
} 
Espírito de Deus que impulsionou os apóstolos na missão de levar a revelação de Cristo a todos. A Igreja é a grande assembleia reunida por Deus, em torno do mistério pascal do seu Filho e da graça do Espírito. Ela chegará à sua consumação quando todos os membros do Cristo estiverem agregados ao seu Corpo.

A Igreja é, portanto, o edifício de Deus, constituído a partir dos inúmeros fiéis que acolheram a Boa Nova e a verdadeira gnose que é a doutrina dos apóstolos difundida na Igreja em todo tempo e por todo o mundo.

Ademais, Irineu compreende a Igreja a partir dos que receberam de Cristo, através dos apóstolos, a missão de conduzir e pastorear os fiéis. De fato pela sucessão apostólica os encarregados de tal ministério transmitem a tradição recebida de fonte segura, proclamam as Sagradas Escrituras e ensinam a regula fidei. A Tradição apostólica é indicada como um critério de autoridade para a comunidade cristã, ou seja, é aquilo que dava fundamento e autenticidade para o modo de vida dos cristãos. A regra de fé é um instrumento de discernimento entre as verdades de fé e os desvios ensinados pelos gnósticos, que a Igreja, constituída pelo Senhor como luz, através da pregação verdadeira e firme a utiliza para iluminar o caminho até a vida verdadeira em Jesus Cristo.

Estas são três bases fundamentais da vida cristã, que a partir do banho da regeneração, que mergulha a pessoa no mistério trinitário, sustenta os fiéis na sua vida concreta, enquanto Cristo os alimenta com seu corpo e sangue, mistério de Deus comunicado pela Igreja aos que creem.

Além disso, para Irineu a presença da Virgem no mistério e no ministério de Jesus Cristo foi essencial. Sendo assim, ela é o modelo de obediência à vontade do Senhor e de decisão pela vida plena em Deus, que nos vem pelo seguimento do seu Filho Jesus Cristo e pela abertura à graça do Espírito.

Portanto, a Igreja no segundo século da era cristã, compreendida através da hermenêutica dos textos irineanos, é entendida unida à missão do Filho de Deus no seu projeto salvífico, concatenando antiga e nova promessa numa única Aliança. Da Encarnação à Parusia, a missão da Igreja é concretizar e consolidar a recapitulação da criação, iniciada por Jesus Cristo. É uma Igreja presente no mundo, mas que se sabe não pertencente a ele. Desenvolve sua missão dada pelo Filho, é conduzida e iluminda pelo Espírito, e reconduz ao Pai os filhos dispersos, até que em Cristo tudo será consumado. 


\section{4. \\ A Lumen gentium e a eclesiologia de Irineu de Lião}

\section{1. \\ O retorno às fontes e sua influência no Concílio Vaticano II}

No discurso de abertura do Concílio Ecumênico Vaticano II, a 11 de outubro de 1962, o papa João XXIII apresentou as motivações que o inspiraram a convocar um Concílio, visto que iluminada pela luz deste Concílio, a Igreja engrandecerá "em riquezas espirituais e olhará intrépida para o futuro. Com atualizações oportunas, e com a prudente coordenação, a Igreja conseguirá que os homens, as famílias e os povos voltem realmente a alma para as coisas celestiais" $" 599$.

Destaca-se, dessas motivações, uma crítica do pontífice aos profetas da desventura, que anunciam prevaricações e ruínas em nosso tempo, como se estivesse iminente o fim do mundo, exaltando os Concílios precedentes, como o triunfo da ideia e da vida cristã. Ademais, afirmam que o mundo hodierno está demasiadamente ocupado com a política e as controvérsias de ordem econômica, não mais disponível às questões de ordem espiritual, propaladas pela Igreja. Contudo, João XXIII não vê nestas novas condições da vida moderna só desvantagens, pois neste Concílio a Igreja poderá olhar para si mesma, desvinculada da intromissão indevida das autoridades civis, que muitas vezes protegeram, mas também provocaram danos espirituais à Igreja.

Para tal reflexão, João XXIII apresenta como a doutrina deve se desenvolver no decorrer do Concílio, não se apoiando nas condenações proferidas pelo seu antecessor a tantos teólogos, nem nos profetas da desventura, mas apontando novas direções para uma hermenêutica das novas realidades culturais, sociais e humanas:

O XXI Concílio Ecumênico se aproveitará da eficaz e importante soma de experiências jurídicas, litúrgicas, apostólicas e administrativas, que por vinte séculos se tornaram patrimônio comum dos homens. É nosso dever não só

${ }^{599}$ JOÃO XXIII, Discurso de Sua santidade papa João XXIII na abertura do SS. Concílio. 
conservar este tesouro precioso, mas também dedicar-nos com vontade pronta e sem temor àquele trabalho hoje exigido. É necessário que esta doutrina certa e imutável, que deve ser fielmente respeitada, seja aprofundada e exposta de forma a responder às exigências do nosso tempo. Uma coisa é a substância do 'depositum fidei' e outra é a formulação com que são enunciadas. Será preciso atribuir muita importância a esta forma e insistir com paciência, na sua elaboração; e dever-se-á usar a maneira de apresentar as coisas que mais corresponda ao magistério, cujo caráter é prevalentemente pastoral ${ }^{600}$.

O aggiornamento $^{601}$ proposto pelo papa João XXIII não surge nos períodos conciliares, mas é gestado desde o século XIX, quando alguns teólogos e escolas teológicas decidiram sair de um modelo escolástico e manualista de ensinar teologia. Visto que, depois do Concílio Vaticano I, segundo J. Libânio, com o primado do romano pontífice e a infalibilidade do magistério papal, em virtude da não aceitação de muitas afirmações conciliares, a teologia assumiu com unhas e dentes a tarefa de defender as questões dogmáticas. Foi crescente a separação entre os teólogos manualistas e o pensamento moderno ${ }^{602}$.

Num movimento contrário, na Escola de Tübingen, no século XIX, os teólogos buscavam um diálogo com o romantismo e o idealismo alemão, desvincilhando-se do método especulativo e histórico-positivo. Algumas dessas inovações teológicas chegaram ao colégio Romano, por meio de professores jesuítas.

Na França, no início do século XX, floresceu um despertar teológico para o estudo da exegese, patrologia e história da Igreja. Na Alemanha, alguns teólogos da Faculdade Teológica de Innsbruck - J. A. Jungmann, H. Rahner, J. Lotz propuseram um ensino diferente de teologia, a partir de duas diferentes perspectivas: uma acadêmica, erudita e sistemática, para formação de professores; e outra centrada no projeto salvífico de Deus, realizado em Cristo, mais voltado para a pregação. As ideias de reforma da teologia e, consequentemente, da Igreja sofreram tribulações vindas de Roma e do movimento anti-modernista ${ }^{603}$.

A nouvelle théologie, que adentrou o Concílio Vaticano II, foi uma expressão da reflexão moderna teológica, que ganhou força a partir da destruição

\footnotetext{
${ }^{600}$ JOÃO XXIII, Discurso de Sua santidade papa João XXIII na abertura do SS. Concílio.

${ }^{601}$ Aggiornamento, vocábulo em linguagem italina, significa: pôr em dia ou manter em dia; modernização, adequação a exigências ou critérios novos; adiamento. No âmbito do Concílio Vaticano II foi usado pelo papa João XXIII e passou a ser eclesialmente sem tradução.

(ALMEIDA, A., Aggiornamento, p. 8-9).

${ }^{602}$ LIBÂNIO, J., Concílio Vaticano II, p. 37.

${ }^{603}$ O'MALLEY, J., Volta às fontes e reforma no Vaticano II, p. 48-49; LIBÂNIO, J., Concílio Vaticano II, p. 38-39.
} 
provocada pela Segunda Guerra Mundial, principalmente com seus transtornos humanos, espirituais, culturais e físicos. Em 1950, como afirma O’Malley ${ }^{604}$, Yves Congar publicou uma artigo intitulado Verdadeira e falsa reforma da Igreja, que levou o núncio apostólico para a França, dom Giovanni Roncalli, a se questionar se era possível uma reforma da Igreja.

Anos antes, outro membro da nouvelle théologie, Jean Daniélou, publicou um artigo intitulado As orientações atuais do pensamento religioso, no qual levantava uma tríplice exigência para a reflexão teológica: tratar de Deus como Deus, ou seja, como sujeito; responder às vivências do homem moderno, principalmente em relação aos avanços nas ciências e na história; por fim, envolver o ser humano por completo, em engajamento e interior.

Diante das perseguições oriundas do Santo Ofício, os teólogos da nouvelle théologie - jesuítas e dominicanos - trocaram o vocábulo ao se referir à Igreja, de reforma para ressourcement - volta às fontes cristãs. Como afirma G. Flynn, nessa mudança semântica, o movimento de reforma teológica encontrou nas fontes cristãs, primeiro medievais, depois patrísticas, um recurso para utilização dos novos métodos de crítica literária desenvolvidos pela modernidade ${ }^{605}$. Esse movimento teológico não se limitou aos franceses, mas seguiu também para Alemanha, Holanda, Suíça, Estados Unidos; até em Roma já se apontavam os novos métodos na reflexão teológica.

Aggiornamento, reforma ou renovação, ressourcement, desenvolvimento foram palavras que motivaram o caminho do movimento teológico pré-conciliar e que entraram nas reflexões e nos textos conciliares com toda a força, por mais que Pio XII, com a encíclica Humanis generis, em 1950, tenha cortado os rebentos mais verdes desta nova reflexão teológica que surgia. Em 1959, com a convocação do Concílio Vaticano II e sua preparação nos três anos subsequentes, uma brilhante geração de teólogos - Y. Congar, J. Daniélou, H. De Lubac, P. Chenu, K. Rahner, J. Ratzinger, H. Küng, E. Schillebeechx, J. Alfarro, G. Philips, R. Latourelle, M. Flick, J. Fuchs, entre outros - estava preparada para as renovações necessárias.

No decorrer do Concílio, três termos circulavam entre os pensadores católicos, segundo O'Malley: aggiornamento, desenvolvimento e ressourcement.

${ }^{604}$ O’MALLEY, J., Volta às fontes e reforma no Vaticano II, p. 50.

${ }^{605}$ FLYNN, G.; MURRAY, P., Ressourcement, p. 1-12. 
O termo aggiornamento se destacou mais propriamente para apresentar o objetivo fundante do Concílio: uma renovação; mas não atuou profundamente na metodologia conciliar. As ideias de desenvolvimento e progresso trouxeram uma atitude de reflexão muito presente ao Concílio, a ponto de os padres conciliares afirmarem, na Dei verbum, que "esta tradição, oriunda dos apóstolos, progride [proficit] na Igreja sob a assistência do Espírito Santo: cresce [crescit], com efeito, a compreensão tanto das coisas como das palavras transmitidas" ${ }^{\text {606 }}$. Por mais que alguns tenham se oposto, o Concílio afirmou que a tradição dos apóstolos é uma realidade que evolui e se desenvolve, afirmação que, uma década antes, seria condenável $^{607}$.

O ressourcement foi o terceiro termo mais usado, no Concílio, para se referir à mudança, e ele se difere de desenvolvimento, pois o retorno às fontes cristãs é uma atitude humana e deliberada, visto que é a reflexão humana que possibilita a hermenêutica dessas fontes. Ademais, o ressourcement usa o passado para julgar e criticar o presente e, assim, reformá-lo ou mudá-lo.

Na declaração Dignitatis humanae, os padres conciliares explicam o sentido de ressourcement: "este Concílio Vaticano investiga a sagrada tradição e doutrina da Igreja, das quais tira novos ensinamentos, sempre concordantes com os antigos"

A busca pelas fontes da revelação e o resgate da tradição são as propostas que conduziram os padres conciliares deste o primeiro período de trabalho, pois na fase preparatória pouco se reportou às fontes cristãs. Porém, com o início dos debates e a rejeição dos primeiros esquemas, o discurso de João XXIII ecoou no Concílio e os padres trouxeram, na medida do possível e do acesso, as fontes cristãs para dentro dos debates, dos novos esquemas e das intervenções nas aulas conciliares.

O ressourcement, conforme D. Gianotti, tornou-se, para os padres conciliares, uma atitude espiritual que conduziria a uma reelaboração da reflexão teológica na sua perspectiva mais profunda e, assim, à renovação da Igreja. Esse movimento de renovação espiritual conduzia os Padres a se voltarem para o

\footnotetext{
${ }^{606}$ CONCÍLIO VATICANO II, Dei verbum 8.

${ }^{607}$ O’MALLEY, J., Volta às fontes e reforma no Vaticano II, p. 52.

${ }^{608}$ CONCÍLIO VATICANO II, Dignitatis humanae 1; O'MALLEY, J., Volta às fontes e reforma no Vaticano II, p. 54.
} 
modelo das primeiras comunidades cristãs, sua inspiração nas Escrituras e a norma dos Padres ${ }^{609}$.

Entretanto, nas aulas conciliares, o trabalho era teológico, e não somente espiritual. Neste sentido, a questão do retorno às fontes cristãs se tornou mais complexa. A abordagem teológica dos textos fontais, sem o devido conhecimento prévio, provoca um desmantelamento das fontes bíblicas, litúrgicas, patrísticas e medievais ${ }^{610}$. Isso acontece no Vaticano II, pois os padres conciliares e muitos teólogos ainda conservam uma forma de abordagem neoescolástica, do século XIX, na qual não se faz a hermenêutica do texto diretamente, mas sim com o auxílio de manuais.

Sendo assim, como afirma D. Gianotti, durante as aulas conciliares não se vence a ingenuidade da abordagem das fontes que marcaram o início do ressourcement, e a racionalidade neoescolástica ainda comanda o desenvolvimento da doutrina. Mesmo assim, em todo o Concílio se delineou um caminho potencial para o retorno às fontes, por mais que a abordagem ainda tenha sido ingênua e superficial. No entanto, o Concílio Vaticano II ajudou a Igreja a recuperar o valor das fontes doutrinais e da vida eclesial ${ }^{611}$.

Em se tratando do esquema De Ecclesia, que fora rejeitado na sua primeira versão, segundo H. De Lubac, o cardeal Montini, no seu discurso nos últimos dias do primeiro período, apelou para que o documento sobre a Igreja expressasse a glorificação de Cristo, pois a Igreja de Cristo deve expressar o pensamento de Cristo e reproduzir sua imagem. Para tanto, afirma H. De Lubac, o futuro papa apela para uma teologia que retorne às fontes bíblicas e patrísticas para pensar a Igreja, saindo do universo jurídico.

Dom Butler, dois dias após esse discurso, convoca os padres conciliares a olharem para o esforço de renovação teológica, que estava sendo construído na Igreja, pois esta renovação seria como um sopro do Espírito, um sinal da vitalidade eclesial, um chamado de Deus para compreendermos a necessidade dos novos tempos ${ }^{612}$.

\footnotetext{
${ }^{609}$ GIANOTTI, D., Ressourcement, p. 28-35.

${ }^{610}$ GIANOTTI, D., Ressourcement, p. 36-39.

${ }^{611}$ GIANOTTI, D., Ressourcement, p. 42-46.

${ }^{612}$ DE LUBAC, H., Liminar, p. 30-31.
} 
O aggironamento da Igreja parte de uma renovação interior. Mergulhar nas raízes da fé, inspirar-se nas Escrituras, unir-se a toda a tradição viva da Igreja ${ }^{613}$. Y. Congar reforça a importância de compreender o Vaticano II como um todo e, também, especificamente na Lumen gentium, não como um conjunto de normas e reformas, mas sim como algo que se aprofunda e se prolonga por todas as igrejas, em todos os cristãos e permanece por gerações. Isso porque, ao se voltar para a vida da Igreja antiga e reescrever, a partir de lá, uma eclesiologia, torna-se necessário um amadurecimento contínuo da experiência feita, para, assim, ter uma maior profundidade nas Escrituras e na tradição e delas beber mais ainda ${ }^{614}$.

Tendo isso em vista, o próprio Y. Congar escreve, algumas décadas após o término do Concílio, que as referências que o Vaticano II faz aos Padres da Igreja são meramente ornamentais. Logo, tornou-se necessário um estudo mais aprofundado das referências patrísticas dentro dos textos conciliares, a fim de possibilitar um aprofundamento maior nas propostas apresentadas no Vaticano $\mathrm{II}^{615}$. Ademais, o papa Bento XVI, ao comemorar cinquenta anos do término do Concílio, convocou os teólogos a uma hermenêutica da reforma iniciada no Vaticano II $^{616}$.

Portanto, o retorno às fontes, iniciado no século XX, ainda motiva a Igreja e os estudiosos a olharem com mais afinco as raízes da fé cristã, especialmente nas Escrituras e nos Padres da Igreja, com métodos críticos modernos e uma melhor abordagem histórica e contextual.

\section{2.}

\section{A Constituição Dogmática Lumen gentium ${ }^{617}$}

Na Encíclica Mystici Corporis - o Corpo Místico de Jesus Cristo e nossa união nele com Cristo -, do papa Pio XII, ao tratar da Igreja como Corpo Místico de Cristo, propõe-se a apresentar a perspectiva jurídica e hierárquica da Igreja,

\footnotetext{
${ }^{613}$ DE LUBAC, H., Liminar, p. 32.

${ }^{614}$ CONGAR, Y., À guisa de conclusão, p. 1285-1292.

${ }^{615}$ GIANOTTI, D., I Padri della Chiesa al concilio Vaticano II, p. 9.

${ }^{616}$ BENTO XVI, Discurso do papa Bento XVI aos cardeais, arcebispos e prelados da cúria romana na apresentação dos votos de Natal; O'MALLEY, J., Volta às fontes e reforma no Vaticano II, p. 55-57.

${ }^{617}$ Os relatos aqui apresentados são baseados em: BARAÚNA, G., A Igreja do Vaticano II, p. 2126; KLOPPENBURG, B., As vicissitudes da Lumen gentium na aula conciliar, p. 194-251; VITALI, D., Lumen gentium, p. 11-36; ROUTHIER, G., Introduzione alla costituzione dogmatica Lumen gentium, p. 13-52.
} 
pensada para o Concílio Vaticano I, com uma roupagem cristológica retirada da teologia paulina sobre o Corpo de Cristo. "Para definir e descrever a verdadeira Igreja de Cristo - santa, católica, apostólica Igreja Romana - nada há mais nobre do que o conceito ‘Corpo Místico de Jesus Cristo’; que nas Sagradas Escrituras e dos Santos Padres frequentemente se ensina" ${ }^{\text {618 }}$. Sendo assim, ao invés de a Igreja ocupar o centro da reflexão como instituição e societas perfectae, sua compreensão fundante vem do próprio Senhor, mas sem deixar de trazer presente a perspectiva jurídica e hierárquica na sua eclesiologia.

O esquema sobre a Igreja apresentado pelo cardeal Tardini, secretário de Estado, ao cardeal Ottaviani, presidente da Pontifícia Comissão Teológica para o Concílio Ecumênico Vaticano II, assemelha-se muito ao esquema sobre a Igreja, apresentado no Concílio Vaticano I. A única diferença entre ambos é que este se inicia com o capítulo sobre a Igreja Corpo Místico de Cristo e o primeiro se inicia tratando da natureza da Igreja militante. Porém, os dois se somam à encíclica de Pio XII e simplesmente dão uma nova roupagem à teologia manualística da Igreja, conservando o mesmo modelo dos últimos cem anos. Ignoram os avanços realizados pelos movimentos bíblico, litúrgico, teológico e patrístico, bem como as reflexões da Nouvelle Théologie - condenadas pelo papa Pio XII na encíclica Humani generis -, o que resultará na rejeição, por parte dos padres conciliares, do esquema sobre a Igreja, no final do primeiro período do Concílio Vaticano II, acusado principalmente de ser muito apologético e jurídico.

Em virtude disso, foi constituída uma subcomissão De Ecclesia para reunir as diversas propostas que chegaram à Comissão Teológica do Concílio, a fím de reelaborar o esquema sobre a Igreja. Entre essas novas propostas e esquemas, destacou-se, pelos membros da subcomissão, o “esquema dos belgas", também conhecido como "esquema Philips". Ao ser assumido pelo cardeal König como o melhor para conduzir os trabalhos da subcomissão, os outros membros o apoiaram e o cardeal Ottaviani fora vencido. Desta forma, o padre Gerard Philips, organizador do "esquema belga", foi cooptado para secretário dessa subcomissão.

Este novo esquema sobre a Igreja estava dividido em trinta e seis parágrafos e quatro capítulos: I. O mistério da Igreja; II. A constituição hierárquica da Igreja, em particular o episcopado; III. O Povo de Deus, em particular os leigos; IV. A

${ }^{618}$ PIO XII, Mystici corporis, 13. 
vocação à santidade da Igreja. O novo esquema De Ecclesia foi dividido em duas partes para ser apreciado por João XXIII, que aprovou os dois capítulos da primeira parte; posteriormente, o papa Paulo VI aprovou toda a segunda parte.

O segundo período do Concílio Vaticano II (29/set a 04/dez 1963) foi aberto com o discurso de Paulo VI, afirmando não somente a continuidade do Concílio, mas também que neste segundo período as discussões eclesiológicas seriam dominantes:

se nós, veneráveis irmãos, colocarmos diante dos nossos olhos esta soberana ideia - de que Cristo é o nosso Fundador, a nossa cabeça invisível mas real, e nós, todos, recebemos d'Ele tudo, de modo que, assim, formamos com Ele aquele "Christus totus", o Cristo total, de que fala Santo Agostinho e de que a teologia da Igreja está intimamente penetrada - podemos compreender melhor os fins principais deste Concílio, que, por motivo de brevidade e de melhor inteligência, indicaremos em quatro pontos: o conhecimento, ou, se se preferir, a consciência da Igreja; a sua reforma; a recondução de todos os cristãos à unidade; e o diálogo da Igreja com o mundo contemporâneo ${ }^{619}$.

O novo esquema sobre a Igreja passou por vinte e duas congregações gerais (30/set a 31/out 1963) até chegar à sua estrutura definitiva, necessitando de ser revisado em virtude das diversas emendas inseridas, para, então, retornar no terceiro período.

A estrutura final foi dividida em oito capítulos: I. O mistério da Igreja; II. O Povo de Deus; III. Constituição hierárquica da Igreja, em particular o episcopado; IV. Os leigos; V. Vocação universal à santidade na Igreja; VI. Os religiosos; VII. Índole escatológica da Igreja peregrina e sua união com a Igreja celeste; VIII. A Bem-aventurada Virgem Maria, Mãe de Deus, no mistério de Cristo e da Igreja.

As maiores discussões centraram-se no terceiro capítulo, o qual teve a elaboração de um esquema separado de votação, para conseguir abarcar todas as propostas. Além deste, o oitavo capítulo, sobre a Virgem Maria, teve uma votação dramática - 1.114 placet e 1.074 non placet -, que levou à discussão se não seria melhor manter dois esquemas separados, um sobre a Igreja e outro sobre a Virgem Maria. Com a intervenção do papa Paulo VI, chegou-se à solução de que seria inserido o esquema sobre a Virgem Maria no esquema sobre a Igreja, mas com a devida honra e reconhecimento, principalmente em virtude da votação expressiva.

${ }^{619}$ PAULO VI, Discurso do papa Paulo VI na solene inauguração da $2^{\mathrm{a}}$ sessão do Concílio Vaticano II. 
Entre o segundo e terceiro períodos, o papa Paulo VI lançou a Encíclica Ecclesiam suam - sobre os caminhos da Igreja -, motivando e reforçando nos fiéis a necessidade de uma renovação eclesial:

vivemos a hora de a Igreja aprofundar a consciência de si mesma, meditar sobre o seu mistério, investigar para sua instrução e edificação a doutrina, que já lhe é conhecida e foi elaborada e difundida de modo especial neste último século, sobre a sua origem, natureza, missão e destino. Esta doutrina nunca será, porém, exaurientemente estudada e compreendida, pois contém a "dispensação do mistério escondido há séculos em Deus... para que se manifeste... pela Igreja” (Ef 3,9-10), isto é, contém a misteriosa reserva dos misteriosos desígnios divinos que, por meio da Igreja, são publicados. Essa doutrina constitui, apesar disso, o tema que hoje mais deseja examinar aquele que pretende ser discípulo dócil de Cristo e, mais ainda, quem, como nós e como vós, Veneráveis Irmãos, foi posto pelo Espírito Santo como Bispo para governar a Igreja de Deus ${ }^{620}$.

O terceiro período (14/set a $21 /$ nov 1964) foi aberto com um discurso do papa Paulo VI sobre a questão eclesiológica, enfatizando a colegialidade. Isso acabou gerando muitas discussões entre os padres, o que o papa resolveu emitindo uma nota prévia, com explicação sobre o sentido de colegialidade, a qual encontra-se no final do documento Lumen gentium, dividida em quatro parágrafos.

Após a votação dos novos capítulos, um a um - dois amplamente reelaborados sobre o Povo de Deus e sobre a Virgem Maria -, foram feitas as alterações solicitadas e no dia 21 de novembro de 1964 a Constituição Dogmática Lumen gentium foi solenemente promulgada com uma votação geral de 2.151 placet e somente 5 non placet.

A Lumen gentium colocou as questões sobre a Igreja no centro do Concílio Vaticano II, não somente porque favoreceu uma discussão ampla sobre a eclesiologia, pois por três períodos de sessões e dois intervalos entre os períodos motivou com afinco a discussão sobre o tema, mas também porque mostrou que, para fazer um aggiornamento, ou definir a presença da Igreja no mundo, sua ação pastoral e sua organização, é preciso refletir sobre seus fundamentos e identidade, além de ouvir a tradição e os Santos Padres. Como diz o papa Paulo VI, é preciso que a Igreja olhe para si mesma e responda: Igreja, o que diz de si mesma? A Constituição sobre a Igreja é o documento central do Concílio Vaticano II.

${ }^{620}$ PAULO VI, Ecclesiam suam 3. 
4.3.

A Lumen gentium e a eclesiologia de Irineu de Lião

Tendo como fundamento o pensamento eclesiológico de Irineu, exposto no capítulo anterior, agora se buscará analisar o texto conciliar sobre a Igreja, não por ele mesmo, mas tendo como paralelo a teologia irineana. O processo de comparação tem por objetivo, mais do que encontrar pontos de convergência, oposição e conjugação, perceber como essa fonte primeva da teologia cristã pode auxiliar uma hermenêutica e uma maior compreensão das propostas conciliares.

Ambos os textos distam mais que dezessete séculos, porém se assemelham no contexto da escrita: a Igreja diante das realidades que a interpelam.

Irineu de Lião, como bispo da Gália, escreve num tempo marcado pelas influências das teorias gnósticas dentro das comunidades cristãs, as quais confundiam e distanciavam as pessoas da obra da salvação iniciada em Jesus Cristo e da missão da Igreja no mundo. Os padres conciliares, diante das condições do mundo, percebem a urgência de a Igreja retomar sua missão: levar a luz de Cristo para tantos homens e mulheres que vivem nas sombras ${ }^{621}$.

As seis partes que seguem foram organizadas pensando na comparação da Lumen gentium com a eclesiologia de Irineu. Temas como os leigos e os religiosos não foram abordados especificamente, pois, para o bispo de Lião, estes formavam o Povo de Deus sem a distinção que se faz atualmente.

A medotologia utilizada foi uma explanação dos principais números da Lumen gentium, utilizando comentadores oriundos do próprio Concílio e também dos tempos hodiernos, numa nova perspectiva teológica e com novos métodos. A partir desses comentários à Constituição Dogmática, foram traçadas comparações e comentários dos pontos que convergem, retrocedem ou avançam com a eclesiologia irineana.

\subsection{1. O mistério da Igreja}

O primeiro esquema apresentado no Concílio Vaticano II sobre a Igreja foi rejeitado pela maioria dos padres conciliares, visto que conservava o tratado $D e$ Ecclesia, apresentado na sua forma apologética tradicional - no Concílio Vaticano

${ }^{621}$ CONCÍLIO VATICANO II, Lumen gentium 1. 
I -, que enfatizava o Cristo como fundador da Igreja e a Igreja como Corpo Místico de Cristo, mostrando assim a impossibilidade da salvação extra ecclesiam.

O "esquema Philips", base da Constituição Dogmática Lumen gentium, desde sua primeira apresentação, trazia no primeiro capítulo $O$ mistério da Igreja, no qual o autor apresentava a Igreja inserida no mystérion - em grego -, ou seja, "o desígno eterno de Deus em favor da humanidade" ${ }^{622}$. Esse novo esquema sobre a Igreja propunha uma compreensão eclesial mais ampla e baseada nas Escrituras, além de colocar como ponto central do fundamento da Igreja Jesus Cristo, luz dos povos.

Sendo assim, ao iniciar o documento com as palavras: "a luz dos povos é Cristo" ${ }^{\text {,623 }}$, o Concílio buscou muito mais do que renovar o tratado De Ecclesia, mas sim dar à Igreja outra perspectiva hermenêutica, que somente uma Constituição Dogmática poderia possibilitar ${ }^{624}$, ou seja, o mistério da Igreja, que tem em Cristo seu fundamento e sustenação.

O Cristo luz dos povos remete "ao misericordioso coração de nosso Deus, pelo qual nos visita o Astro das alturas, para iluminar os que jazem nas trevas" (Lc 1,78-79), e este "Astro das alturas" 225 é um título messiânico, o que vem do Alto e traz a luz. Além disso, o texto também remete à interpretação dos Padres da Igreja sobre a relação entre Cristo e Igreja, na metáfora do Sol e da Lua ${ }^{626}$, pois a lua reflete a luz que recebe do Sol. Neste contexto, o vínculo do mistério da Igreja está diretamente relacionado com o Cristo, "Sol do Oriente que veio nos visitar", como canta a Igreja todas as manhãs.

Irineu de Lião afirma que à Igreja foi concedida a luz de Deus ${ }^{627}$, Jesus Cristo. Contudo, essa luz não é reservada para ela egoisticamente, mas da mesma forma que afirma o proêmio da Lumen gentium: "por isso, este sagrado Concílio, reunido no Espírito Santo, deseja ardentemente iluminar com a sua luz, que resplandece no rosto da Igreja, todos os homens, anunciando o Evangelho a toda a criatura",628. Também afirma Irineu: "com efeito, em todo lugar, a Igreja prega a

\footnotetext{
${ }^{622}$ VITALI, D., Lumen gentium, p. 35.

${ }^{623}$ CONCILIO VATICANO II, Lumen gentium 1.

${ }^{624}$ VITALI, D., Lumen gentium, p. 38.

${ }^{625}$ IRINEU de Lião, Adversus haereses III, 10, 2.

${ }^{626}$ RAHNER, H., Simboli della chiesa, p. 205-229.

${ }^{627}$ IRINEU de Lião, Adversus haereses V, 20, 1; III, 10, 2.

${ }^{628}$ CONCÍLIO VATICANO II, Lumen gentium 1.
} 
Verdade, verdadeiro candelabro de sete braços, trazendo a luz de Cristo" ${ }^{629}$. A Igreja acolhe a luz de Cristo e reflete-a aos seus, para que sejam iluminados pela graça do Senhor.

A luz que ilumina a Igreja é o sacramento de Cristo para o mundo e para todas as realidades existentes, pois a sua ressurreição não foi para si mesmo, mas para que todos seguissem o Salvador e participassem da salvação que Ele concedeu, visto que, seguindo a luz, obterão a luz. "Não são os que estão na luz que a iluminam, mas são eles iluminados e feitos resplandecentes por ela; longe de lhe proporcionar alguma coisa, são eles a receber os benefícios e a ser iluminados por ela" ${ }^{\text {630 }}$.

Irineu, segundo Y. Andia, mostra uma consciência clara da missão da Igreja de ser no mundo sinal do Cristo luz, para iluminar a todos com a verdade e com a graça que ela recebe do Alto; "a pregação da verdade e a imagem de nossa salvação: assim é o caminho da vida que os profetas anunciaram, o que Cristo instituiu, que os apóstolos consignaram e que a Igreja transmite a seus filhos por toda a terra" ${ }^{931}$. A imagem da luz do Sol que brilha sobre todo o mundo, é a luz da pregação e da fé da Igreja em Cristo, que ilumina todos os povos e os une sob uma mesma fé. Esta é a catolicidade da Igreja, que anuncia a todos a Verdade que recebeu do Pai, pelo Filho, e o faz por meio do Espírito ${ }^{632}$.

Portanto, a Igreja não é, ela própria, a luz dos povos, segundo W. Kasper. A luz dos povos é Jesus Cristo, em cuja face humana resplandece a imagem do Deus Vivo. E Irineu resume isso afirmando que "Deus é a glória do homem e o homem é o receptáculo da obra, de toda a sabedoria e do poder de Deus", ou ainda, "a glória de Deus é o homem que vive e a vida do homem consiste na visão de Deus" ${ }^{\prime 633}$.

Desta forma, "porque a Igreja, em Cristo, é como que o sacramento, ou sinal, e o instrumento da íntima união com Deus e da unidade de todo o gênero humano"634, este papel de unir os povos ao seu Senhor tornou-se a grande missão universal da Igreja, segundo o Concílio, fazendo-a também instrumento de

\footnotetext{
${ }^{629}$ IRINEU de Lião, Adversus haereses V, 20, 1.

${ }^{630}$ IRINEU de Lião, Adversus haereses IV, 14, 1.

631 IRINEU de Lião, Epideixis 98.

632 ANDIA, Y., Irénée, théologien l'unité, p. 46-47

${ }^{633}$ KASPER, W., A Igreja Católica, p. 105-106; IRINEU de Lião, Adversus haereses III, 20, 2; IRINEU de Lião, Adversus haereses IV, $20,7$.

${ }^{634}$ CONCÍLIO VATICANO II, Lumen gentium 1.
} 
salvação, pois como sacramento ela torna presente o Cristo nas suas ações e como instrumento ela comunica a graça do Cristo a cada um.

Irineu afirmou que a Igreja é "como depósito de grande valor em vaso precioso, que se renova e renova o próprio vaso que a contém" ${ }^{\text {"635 }}$, ou seja, ela não só comunica a graça de Deus, que recebeu pelo Espírito Santo, como também essa mesma graça age nela mesma, transformando-a. Por isso, como sacramento e instrumento

este dom de Deus foi confiado à Igreja, como o sopro de vida inspirado na obra modelada, para que sejam vivificados todos os membros que o recebem. É nela também que foi depositada a comunhão com o Cristo, isto é, o Espírito Santo, penhor de incorrupção, confirmação da nossa fé e escada para subir a Deus. ${ }^{636}$

Surge, então, para Irineu a imagem da Igreja como mãe, segundo G. Jossa, que alimenta seus filhos nos seus seios para a vida e, assim, estes recebem a vida da fonte puríssima, que procede do Corpo de Cristo. O sinal sacramental é apresentado com toda a sua profundidade de sinais visíveis e invisíveis: tanto a graça que vem do alto, a ação do Espírito e do Cristo para unirem os povos com o seu Deus, quanto os sinais reais da pregação, atuação, louvor, ensino e resgate dos que são de Deus, para que o encontrem na Igreja e por ela cheguem à plenitude ${ }^{637}$.

A compreensão da Igreja como sacramento é uma construção teológica. Ao analisar esta parte do esquema De Ecclesia, os padres conciliares resgataram não somente a proposta do Concílio de Trento sobre os sete sacramentos, mas também tiveram que voltar às fontes patrísticas, o que ocasionou uma dificuldade, pois os padres conciliares não detinham conhecimento nem acesso a esses textos antigos para a sua hermenêutica ${ }^{638}$.

Mesmo assim, o Concílio Vaticano II afirmou a Igreja como sacramento, sinal e instrumento da união dos homens com Deus, pois a Igreja é como o local onde se manifesta a ação salvífica de Deus e, ao mesmo tempo, o instrumento por meio do qual Deus realiza a sua vontade salvífica ${ }^{639}$. Por isso, não há confusão entre o Concílio de Trento com os sete sacramentos e o Vaticano II com a Igreja

\footnotetext{
635 IRINEU de Lião, Adversus haereses III, 24, 1.

${ }^{636}$ IRINEU de Lião, Adversus haereses III, 24, 1.

${ }^{637}$ JOSSA, G., Regno di Dio e Chiesa, p. 202-206.

${ }^{638}$ GIANOTTI, D., I Padri della Chiesa al concilio Vaticano II, p. 384-385.

${ }^{639}$ REPOLE, R., Il mistero della Chiesa, p. 85; RATZINGER, J., Iglesia, signo entre los pueblos, p. 208-210.
} 
sacramento, porque ambos se completam, já que os sacramentos são os modos em que se realiza a sacramentalidade da Igreja ${ }^{640}$.

Nas fontes patrísticas, mystérion - em grego -, antes de ser traduzido para sacramentum - em latim - e passar a representar as celebrações litúrgicas da Igreja, como Batismo e Eucaristia, correspondia ao eterno desígnio salvador de Deus, que se realiza e se revela aos homens eficazmente. Ou, ainda, seria uma ação divina de salvação, a qual Deus realiza em favor dos homens, para que o reconheçam como Senhor e acolham sua revelação - o que ocasionará uma conversão de vida para este Senhor ${ }^{641}$.

Neste ínterim, uma aproximação ${ }^{642}$ com a teologia irineana torna-se bastante interessante na hermenêutica da Igreja, como sacramento da união entre Deus e os homens. Segundo A. Orbe ${ }^{643}$, a Igreja é a mulher de Lot transformada em estátua de sal - coluna e fundamento -, que foi deixada na terra para suportar as vicissitudes humanas. Enquanto lhe são tirados os membros, pois ela é o sal da terra, conserva sua inteireza como sinal de Deus neste mundo; por isso, é reconhecida como fundamento da fé que confirma seus filhos e os envia diante do seu Pai ${ }^{644}$.

Neste momento da pesquisa, é possível vermos na Igreja sal da terra a Igreja sacramento, pois a estátuta de sal é coluna e fundamento da fé cristã para seus filhos, segundo G. Laiti, mas também os envia para o Pai, preservando-os de toda corrupção da fé. Isso acontece porque "continuamente mutilada, logo aumenta os seus membros e readquire a integridade, do mesmo modo que o seu tipo, a mulher de Lot, a estátua de sal”645.

Nessa tipologia, é possível compreender o eterno desígnio salvador de Deus, que eficazmente deixou a mulher de Lot não com um corpo corruptível, mas com um corpo que não se corrompe e, mutilado, se revigora. Ademais, a Igreja sal da terra é obra divina, pois, mesmo estéril e sem menstruar, ela é fertil no Reino dos

\footnotetext{
${ }^{640}$ RATZINGER, J., Iglesia, signo entre los pueblos, p. 210; SCHILLEBEECKX, E., Cristo sacramento do encontro com Deus, 59-60.

${ }^{641}$ SMULDERS, P., A Igreja como sacramento de salvação, p. 400-410.

${ }^{642}$ Como dito acima, p. 99-113.

${ }^{643}$ ORBE, A., Ecclesia, sal terrae según San Ireneo, p. 219-240.

${ }^{644}$ IRINEU de Lião, Adversus haereses IV, 31, 3.

${ }^{645}$ IRINEU de Lião, Adversus haereses IV, 33, 9.
} 
céus, já que envia continuamente novos filhos, salvos da corrupção do mundo para a salvação eterna ${ }^{646}$.

Os três parágrafos subsequentes da Lumen gentium, do segundo ao quarto, abarcam outro resgate patrístico fundamental da eclesiologia cristã, que é a Igreja alicerçada na Trindade. B. Forte afirma que a Igreja apresentada pela Lumen gentium nasce da Trindade, organiza-se como imagem da Trindade e se dirige para o acabamento trinitário da história. Vem do alto, é modelada pelo alto e caminha na direção dele para o reino definitivo ${ }^{647}$. O resgate das fontes patrísticas torna-se evidente nesses parágrafos, como na referência à afirmação de Cipriano de Cartago: "a concórdia fraterna e a união do povo na unidade que vem do Pai, do Filho e do Espírito Santo"648.

Por conseguinte, os padres conciliares resgataram o mistério fundamental do cristianismo, que é a Trindade, e mostraram que só é possível compreender o mistério da Igreja à luz da economia da salvação: o desígnio salvífico do Pai, a missão do Filho e a ação santificante do Espírito Santo. O Concílio Vaticano II, segundo M. Philipon, não se interessou por apresentar uma teologia intratrinitária ou sobre o mistério da Trindade. Porém, dedicou-se a afirmar o desígnio de cada pessoa divina no mistério eclesial, segundo a linguagem das Escrituras - deixando a parte especulativa para os teólogos -, dedicando-se às questões pastorais e missionárias $^{649}$.

O início do segundo parágrafo apresenta esta ênfase dos padres conciliares na perspectiva da economia salvífica: "O Eterno Pai, pelo libérrimo e insondável desígnio da Sua sabedoria e bondade, criou o universo, decidiu elevar os homens à participação da vida divina e não os abandonou, (...) sempre lhes concedeu os auxílios para se salvarem" ${ }^{650}$. Este referimento ao Pai como Criador e o responsável por elevar o ser humano à participação na vida divina, segundo Repole, não rompe a unidade trinitária, contudo reforça a busca dos padres conciliares em fundamentar as afirmações nas Escrituras. De igual modo, em

\footnotetext{
${ }^{646}$ LAITI, G., La Chiesa nell'economia di Dio, p. 175-178.

${ }^{647}$ FORTE, B., A Igreja, p. 18-19.

${ }^{648}$ CIPRIANO de Cartago, A oração do Senhor 23.

${ }^{649}$ PHILIPON, M., A Santíssima Trindade e a Igreja, p. 361-362.

${ }^{650}$ CONCÍLIO VATICANO II, Lumen gentium 2.
} 
Efésios 1,3-14, Paulo afirma este grande desígnio salvífico do Pai, o qual não está desvinculado do Cristo, pois nos tornamos filhos no Filho ${ }^{651}$.

À vista disto, segundo B. Forte, a unidade dos seres humanos, entre si e com Deus, a partir da encarnação e redenção executada pelo Verbo de Deus, atua historicamente na Igreja. “Aos que creem em Cristo, decidiu chamá-los à Santa Igreja, a qual, prefigurada já desde o princípio do mundo e admiravelmente preparada na história do povo de Israel e na antiga Aliança" ${ }^{\$ 52}$. Então, a Igreja é a participação histórica na unidade da Trindade, é o sacramento da íntima união entre Deus e os seres humanos ${ }^{653}$.

O Filho, segundo a Lumen gentium, foi "enviado pelo Pai, que n'Ele nos elegeu antes de criar o mundo, e nos predestinou para sermos seus filhos de adoção, porque lhe aprouve reunir n'Ele todas as coisas" ${ }^{\text {,654 }}$. De acordo com B. Forte, o desígnio de Deus de unir a todos se manifestou no Filho enviado ao mundo na plenitude dos tempos, para inaugurar "na terra o Reino dos Céus, do qual a Igreja é presença 'in mysterio', isto é, o sinal e o germe que, ao mesmo tempo, revela e esconde" ${ }^{\natural 55}$. Por conseguinte, a Igreja é nomeada de Reino de Cristo, já presente em mistério. Não se trata do reino definitivo, como apresentavam alguns manuais de eclesiologia, segundo Repole. Entretanto, não é totalmente estranha a ele, porque, conforme afirma G. Philips, é ao mesmo tempo o mistério revelado e escondido ${ }^{656}$. Na água e no sangue que jorram do lado aberto de Cristo, os Padres da Igreja abstraíram os sacramentos do Batismo e da Eucaristia, sinal da estrutura sacramental da Igreja que brota da páscoa do Cordeiro $^{657}$.

Consumada a obra do Pai na missão dada ao Filho, "foi enviado o Espírito Santo no dia de Pentecostes, para que santificasse continuamente a Igreja e, deste modo, os fiéis tivessem acesso ao Pai, por Cristo, num só Espírito"658.

Segundo M. Philipon, a economia da salvação é reapresentada no início desse terceiro parágrafo, uma vez que as missões divinas do Filho e do Espírito procedem do Pai e vêm revelar a comunhão da Trindade à Igreja, para com isso

${ }^{651}$ REPOLE, R., Lumen gentium, p. 89-91.

${ }^{652}$ CONCÍLIO VATICANO II, Lumen gentium 2.

${ }^{653}$ FORTE, B., A Igreja, p. 19-20.

${ }^{654}$ CONCÍLIO VATICANO II, Lumen gentium 3.

${ }^{655}$ FORTE, B., A Igreja, p. 20.

${ }^{656}$ REPOLE, R., Lumen gentium, p. 96; PHILIPS, G., La chiesa e il suo mistero, p. 83.

${ }^{657}$ FORTE, B., A Igreja, p. 20; REPOLE, R., Lumen gentium, p. 97.

${ }^{658}$ CONCÍLIO VATICANO II, Lumen gentium 4. 
encaminhá-la pelo Filho, no Espírito, ao Pai. A ação do Espírito na vida da Igreja é que possibilita sua fidelidade ao projeto de Deus iniciado em Jesus Cristo, visto que "o Espírito habita na Igreja e nos corações dos fiéis, como num templo", arrematando a obra redentora do Filho ${ }^{659}$.

Na sua missão pastoral, segundo R. Repole, o Concílio apresenta a missão da Igreja e dos fiéis conduzida e iluminada pelo Espírito, concedendo-lhe seus dons e organizando sua ação no mundo, em vista da concretização da obra salvadora do $\mathrm{Pai}^{660}$.

Aproximando o texto conciliar à teologia irineana ${ }^{661}$, inicialmente é preciso afirmar, segundo E. Osborn, que a Igreja declara a fé no Pai, no Filho e no Espírito Santo, do início ao fim dos escritos de Irineu ${ }^{662}$. A Igreja espalhada pelo mundo inteiro anuncia e testemunha a herança apostólica que lhe transmitiu uma única fé no Pai, o qual, na sua obra criadora, fez tudo o que existe por meio das suas duas mãos - o Verbo e o Espírito. Ele enviou o Filho para resgatar a criação e o ser humano decaído, e o Espírito, como penhor de vida e caminho para chegar a Deus.

Jesus Cristo, o Filho unigênito, segundo B. Sesboüé, veio para recapitular toda a criação na sua obra salvadora. Pela sua encarnação, resgatou o ser humano perdido e o reuniu como assembleia de Deus, constituindo a Igreja, para perpetuar a presença salvadora de Deus no meio dos homens. O Filho resgatou-nos todos como filhos adotivos pelas águas da vida e estabelece a comunhão entre Deus e os homens pelo seu corpo e sangue. E o Espírito Santo, que, pelos profetas, anunciou a economia de Deus e em Pentecostes concedeu aos apóstolos o dom de crer e testemunhar a todos o plano salvífico de Deus, de congregar a Igreja numa única e mesma fé, e instrui os fiéis até o fim dos tempos. Este mesmo Espírito age na Igreja e por ela, porque “onde está a Igreja, aí está o Espírito de Deus, e onde está o Espírito de Deus ali está a Igreja e toda a graça"663.

No quarto parágrafo da Constituição Dogmática, há uma referência à obra de Irineu, citando Adversus haereses III, 24, 1, D. Gianotti argumenta que a

\footnotetext{
${ }^{659}$ PHILIPON, M., A Santíssima Trindade e a Igreja, p. 366-367.

${ }^{660}$ REPOLE, R., Lumen gentium, p. 96; PHILIPS, G., La chiesa e il suo mistero, p. 100-101.

${ }^{661}$ Como dito acima, p. 99-113.

${ }^{662}$ OSBORN, E., Irenaeus of Lyons, p. 89-93; IRINEU de Lião, Adversus haereses I, 10, 1; III, 24, 1; V, 20, 1; IRINEU de Lião, Epideixis 41.

${ }_{663}$ IRINEU de Lião, Adversus haereses III, 24, 1; SESBOÜÉ, B., Tout récapituler dans le Christ, p. 183-195.
} 
referência não está no contexto correto, pois Irineu apresenta a identidade da Igreja como mãe e o texto conciliar se refere ao contexto esponsal da Igreja ${ }^{664}$.

Nos parágrafos cinco a sete da Lumen gentium, os padres conciliares apresentam várias imagens da Igreja presentes nas Sagradas Escrituras. No quinto parágrafo, a Constituição Dogmática retoma o seu início - mistério da Igreja -, mas na perspectiva da sua fundação: "O mistério da Santa Igreja manifesta-se na sua fundação. O Senhor Jesus deu início à sua Igreja pregando a Boa Nova do advento do Reino de Deus prometido desde há séculos nas Escrituras" ${ }^{665}$.

Ao relacionar, segundo R. Repole, a missão de Jesus, de anunciar o advento do Reino de Deus à fundação da Igreja, o Concílio não colocou o seu início num momento histórico específico da vida de Jesus. No entanto, para a revelação do mistério que inclui a Igreja, é preciso se atentar para todo o acontecimento histórico da vida de Cristo ${ }^{666}$. A Igreja não é o Reino de Deus, segundo D. Vitali, mas "constitui o germe e o princípio deste mesmo Reino na terra"667. Há um afastamento entre Reino e Igreja, fruto de uma tensão escatológica, do já e ainda não. A promessa anunciada por Cristo, princípio do Reino, só terá seu cumprimento definitivo na parusia. Portanto, a Igreja é o Reino de Deus in mysterio; sua natureza e missão podem ser apreendidas mais por imagens do que por definições ${ }^{668}$.

Irineu, remetendo à tradição dos Patriarcas e Profetas, afirma que estes já semearam na terra as palavras que o Verbo de Deus veio anunciar, e que a Igreja ceifa esta semeadura. Desta forma, "no Reino de Cristo, que está presente a todos para os quais, desde o início, Deus quis que o Verbo estivesse presente ${ }^{\circledR 669}$. Afirma, ainda, que todos os que em sua vida acolheram a Palavra de Deus e com fé anunciaram essa Boa Nova compõem este Reino de Cristo, na terra identificado com a Igreja.

Por outro lado, o bispo de Lião atesta que Deus “introduz no Reino dos Céus Abraão e sua descendência, isto é, a Igreja, que por meio de Jesus Cristo recebe a adoção e a herança prometidas a Abraão" ${ }^{\text {670 }}$. Ou seja, Irineu não fala de

\footnotetext{
${ }^{664}$ GIANOTTI, D., I Padri della Chiesa al Concilio Vaticano II, p. 389.

${ }^{665}$ CONCÍLIO VATICANO II, Lumen gentium 5.

${ }^{666}$ REPOLE, R., Lumen gentium, p. 99-101.

${ }^{667}$ CONCÍLIO VATICANO II, Lumen gentium 5.

${ }^{668}$ VITALI, D., Lumen gentium, p. 47-48.

${ }^{669}$ IRINEU de Lião, Adversus haereses IV, 25, 3.

${ }^{670}$ IRINEU de Lião, Adversus haereses IV, 8, 1.
} 
uma identidade religiosa, mas vai à essência do mistério da Igreja, reafirmando a fé primeva de Abraão como princípio constitutivo daqueles que acolheram o chamado de Deus e são acolhidos na Igreja escatológica. A diástase da Igreja e do Reino, na dinâmica do já e ainda não, na Lumen gentium, está presente na teologia irineana.

Nos parágrafos seis e sete, os padres conciliares apresentaram as imagens da Igreja na Sagrada Escritura, com várias referências, tanto ao Novo Testamento, quanto ao Antigo. Essas imagens, segundo L. Cerfaux, remetem à natureza íntima da Igreja e foram inspiradas na perspectiva semita de compreender nas coisas terrestres o sinal do divino. As Parábolas do Reino, ditas por Jesus, são um exemplo singular e original dessa hermenêutica semita.

Todavia, o movimento cristão, tanto na tradição Paulina como na Joanina, e nos que o seguiram, preferiram se exprimir por meio de alegorias, nas quais a Igreja se revela a si mesma a partir do Espírito, que a conduz em novas direções $^{671}$. O bispo de Lião se assemelha ao movimento cristão dos primeiros séculos, que utiliza alegorias e tipologias para referir-se às diversas definições e figuras da Igreja.

Entretanto, em todo o sétimo parágrafo, os padres conciliares se decidiram por apresentar uma exclusiva imagem da Igreja, baseada na teologia paulina: Corpo Místico de Cristo. Um ponto importante ao ler este parágrafo, segundo L. Cerfaux e R. Repole, é não separar a imagem da Igreja Corpo de Cristo das outras imagens apresentadas no parágrafo precedente e tão pouco das outras figuras presentes nas Sagradas Escrituras ${ }^{672}$.

O texto se estrutura em duas partes, segundo S. Pié-Ninot ${ }^{673}$. Primeiro, faz uma hermenêutica dos texto de 1Cor e Rm na perspectiva dos sacramentos do Batismo e da Eucaristia. Porém, não aparece uma formulação explícita sobre uma eclesiologia eucarística, visto que Paulo faz analogia ao Corpo de Cristo no contexto da celebração eucarística.

$\mathrm{Na}$ segunda parte, os quatro últimos parágrafos, o entendimento do Corpo de Cristo é tirado das cartas deutero-paulinas aos Efésios e ao Colossenses, porém se destacam as quatro citações à Encíclica Mystici Corporis, de Pio XII,

${ }^{671}$ CERFAUX, L., As imagens simbólicas da Igreja no Novo Testamento, p. 331-336.

${ }^{672}$ REPOLE, R., Lumen gentium, p. 121; CERFAUX, L., As imagens simbólicas da Igreja no Novo Testamento, p. 340-341, nota 11.

${ }^{673}$ PIÉ-NINOT, S., Eclesiología, 159-160. 
principalmente a identificação do Corpo Místico de Cristo com a Igreja Católica Romana ${ }^{674}$. No entanto, segundo R. Repole, os padres conciliares também extraem da encíclica de Pio XII o que ela possui de principal, ou seja, a não separação entre a comunhão da graça de Deus e o organismo eclesial visível ${ }^{675}$.

A visão sacramental da Igreja como Corpo de Cristo tem uma repercussão grande entre os Padres da Igreja, segundo W. Kasper ${ }^{676}$, e o Concílio apreendeu pontos importantes destas fontes primárias, pois ao invés de identificar o Corpo de Cristo com a Igreja e enfatizar a continuidade da encarnação do Verbo na Igreja, os padres conciliares enfatizaram que Jesus Cristo "é a cabeça do Corpo que a Igreja é... Todos os membros se devem conformar com Ele, até que Cristo se forme neles" 677 .

Irineu $^{678}$, na Epideixis (90-95), afirma que o que capacita a Igreja a tornar-se Corpo de Cristo e, assim, aproximar-se do seu Senhor, é o Espírito de Deus que atua nela e a ilumina com a graça que vem do Alto. A partir daí, o bispo de Lião mostra como essa Igreja Corpo de Cristo concatena em si todos os filhos e filhas de Deus: a sinagoga do passado, os pagãos, os que ainda virão e todos os dispersos ${ }^{679}$. "Recordamos Irineu que fala da fé vivificante na qual somente a Igreja, mais fecunda que a antiga sinagoga, sustenta seus filhos" ${ }^{\$ 60}$.

Além do mais, segundo G. Jossa, a Igreja Corpo de Cristo é a Igreja dos gentios, que a mãe Igreja aproxima do seu Senhor para serem santificados, como afirma Irineu: "o Senhor haveria por bem formar a sua Igreja com tais homens [oriundos da prostituição] e que a santificaria pelo contacto de seu Filho"681 . A eclesiologia irineana do Corpo de Cristo, segundo G. Laiti ${ }^{682}$, tem na teologia paulina seu fundamento, enfatizando que, pelo Batismo e Eucaristia ${ }^{683}$, o próprio Senhor Jesus gera os filhos para a Igreja, não tendo mais um enviado ou intercessor, mas sim o próprio Senhor.

\footnotetext{
${ }^{674}$ PIO XII, Mystici corporis, 13.

${ }^{675}$ REPOLE, R., Lumen gentium, p. 122.

${ }^{676}$ KASPER, W., A Igreja Católica, p. 179-180.

${ }^{677}$ CONCÍLIO VATICANO II, Lumen gentium 7.

${ }^{678}$ Como dito acima, p. 101.

${ }^{679}$ ROUSSEAU, A., Démonstration de la prédication apostolique, p. 75-77.

${ }^{680}$ DE LUBAC, H., Paradosso e mistero della Chiesa, p. 48.

${ }^{681}$ IRINEU de Lião, Adversus haereses IV, 20, 12; JOSSA, G., Regno di Dio e Chiesa, p.182-184.

${ }^{682}$ LAITI, G., La Chiesa nell'economia di Dio, p. 173-174.

${ }^{683}$ IRINEU de Lião, Adversus haereses V, 2, 2-3.
} 
Seguindo-se a isso, Irineu enfatiza que a unidade da Igreja está representada neste grande e glorioso Corpo de Cristo ${ }^{684}$, e também tem na estrutura ministerial e carismática sua articulação, como afirmam os padres conciliares. Por conseguinte, Igreja Corpo de Cristo, acrescenta G. Jossa, é a Igreja do Senhor Esposa do Senhor, Reino de Cristo -, que recebe de Deus os dons que lhe foram confiados, como o sopro de vida inspirado na obra modelada, para que sejam vivificados todos os membros que o recebem. E também foi na Igreja depositada a comunhão com Cristo, isto é, o Espírito Santo, penhor de incorrupção, confirmação da nossa fé e escada para subir a Deus. Tudo que nutre e sustenta a Igreja Corpo de Cristo, vem do próprio Senhor, como fonte puríssima ${ }^{685}$.

Finalmente, na teologia irineana da recapitulação, Igreja Corpo de Cristo é parte integrante, segundo D. Scordamaglia, pois a fé da Igreja em Cristo abre a porta que recapitula o ser humano, já que o Cristo, cabeça da Igreja, conduz os membros à graça da salvação ${ }^{686}$.

Finalizando o primeiro capítulo, os padres conciliares apresentam uma síntese e uma chave de leitura para compreender o Mistério da Igreja ${ }^{687}$. Segundo D. Gianotti, o Concílio afirma que o mistério da Igreja, neste capítulo inicial, encontra-se concretamente na Igreja católica e que esta Igreja revela nas suas ações o mistério nela contido, agora entre sombras, mas que no final se manifestará plenamente ${ }^{688}$. Esse resgate da perspectiva espiritual da Igreja, completa D. Vitali, soluciona uma discussão de quatro séculos, na qual os reformadores protestantes afirmavam uma Igreja mais espiritual e invisível, e os reformadores católicos respondiam afirmando uma Igreja visível e hierárquica ${ }^{689}$.

A perspectiva teândrica da Igreja - humana-divina - já aparece no início do parágrafo, quando os padres conciliares afirmam que "Cristo, Mediador único, estabelece e continuamente sustenta sobre a terra, como um todo visível, a sua santa Igreja, comunidade de fé, esperança e amor, por meio da qual difunde em todos a verdade e a graça" ${ }^{690}$. Para Irineu, a relação humana-divina, espiritualtemporal da Igreja se expressa na dinâmica do tempo e da sua missão, visto que a

\footnotetext{
${ }^{684}$ IRINEU de Lião, Adversus haereses IV, 33, 7.

${ }^{685}$ JOSSA, G., Regno di Dio e Chiesa, p.185-189; IRINEU de Lião, Adversus haereses III, $24,1$.

${ }^{686}$ SCORDAMAGLIA, D., Ritratti di Cristo in Sant'Ireneo, p. 296-300; Como dito acima, p. 108.

${ }^{687}$ REPOLE, R., Lumen gentium, p. 131.

${ }^{688}$ GIANOTTI, D., I Padri della Chiesa al Concilio Vaticano II, 306-307.

${ }^{689}$ VITALI, D., Lumen gentium, p. 50.

${ }^{690}$ CONCÍLIO VATICANO II, Lumen gentium 8.
} 
Igreja terrestre recebeu do Senhor a ordem de ser coluna e fundamento da fé em meio à criação.

Portanto, sua presença como sal da terra é fundamental para gerar novos filhos e nutri-los até o encontro definitivo, no qual a Igreja humana passará para suas núpcias definitivas com o Cordeiro, como Esposa sem ruga e nem mancha, pois mesmo mutilada - pelas perseguições e martírios - o Espírito a restaurará, para continuar sua missão no Reino de Cristo e conduzir todos ao Reino Eterno.

\subsection{2. \\ O Povo de Deus}

A Igreja novo Povo de Deus ${ }^{691}$, segundo D. Vitali e O. Semmelroth, surge no horizonte conciliar a partir dos debates do segundo período, já com o esquema Philips, que trazia no terceiro capítulo o título: O Povo de Deus, em particular os leigos. Durante os debate, o cardeal Suenens, reforçando a perspectiva pastoral do Concílio em detrimento da eclesiologia do Corpo Místico de Cristo, alterou o esquema De Ecclesia, colocando a Igreja Povo de Deus acima do capítulo sobre a hierarquia eclesiástica. Isso causou uma revolução copernicana nos debates conciliares, porque a ideia de refletir sobre a Igreja novo Povo de Deus, antes restrito ao universo do Antigo Testamento, agora adentrou às discussões eclesiológicas e colocou a hierarquia dentro dessa nova definição. Por conseguinte, o capítulo foi dividido em duas partes e as discussões sobre os leigos ocuparam o quarto capítulo ${ }^{692}$.

As discussões teológicas, segundo H. De Lubac, sobre a Igreja novo Povo de Deus já estava acontecendo décadas antes do Concílio, primeiramente entre os teólogos protestantes, em seguida, entre os teólogos católicos, partindo do Antigo Testamento. Assim, interpretava-se, de forma geral, o termo hebraico qahal como assembleia dos fiéis ou Povo reunido por Deus, o qual, no grego da Septuaginta, foi traduzido por ekklesía ${ }^{693}$.

J. Ratzinger se opõe às discussões dos teólogos do seu tempo que, abrangentemente, apresentam a Igreja como novo Povo de Deus, porém utilizam-

${ }^{691}$ DE LUBAC, H., Paradosso e mistero della Chiesa, p. 43-50; CONGAR, Y., A Igreja Povo de Deus, p. 9.

${ }^{692}$ VITALI, D., Il popolo di Dio, p. 143-145; SEMMELROTH, O., A Igreja: o novo Povo de Deus, p. 476-477.

${ }^{693}$ DE LUBAC, H., Paradosso e mistero della Chiesa, p. 44. 
se somente de argumentos escriturísticos. Para ele, Deus não é propriedade de nada, por isso os cristãos só serão Povo de Deus se estiverem inseridos no Cristo, Filho de Deus e Filho de Abraão ${ }^{694}$.

As discussões teológicas não foram somente acalouradas no pré-Concílio, mas durante este e posteriormente a ele, até que, em 1985, segundo S. Pié-Ninot, foram apresentados pela Comissão Teológica Internacional alguns pontos favoráveis à compreensão da Igreja como Povo de Deus, juntamente com alguns elementos críticos ao conceito ${ }^{695}$.

O segundo capítulo da Lumen gentium representa, segundo D. Vitali e O. Cavaca, o maior ponto de descontinuidade do Concílio Vaticano II a respeito da eclesiologia pré-conciliar. Rompe-se com a perspectiva de societas perfecta e também com o caráter jurídico-societário da eclesiologia medieval, para que se abra um caminho de rica doutrina sobre a Igreja como sujeito histórico, como povo a caminho do reino definitivo ${ }^{696}$.

G. Philips afirma que os dois primeiros capítulos da Constituição Dogmática falam do mistério da Igreja, um na perspectiva transcendental e outro na dimensão histórica. No decorrer da exposição, aparecem os traços fundamentais da Igreja como instrumento de salvação ${ }^{697}$.

A interpretação desse capítulo, à luz da teologia irineana, será dividida em três partes: a Igreja novo Povo de Deus, o sacerdócio comum dos fiéis e o caráter missionário da Igreja.

O nono parágrafo da Lumen gentium inicia afirmando que "aprouve a Deus salvar e santificar os homens, não individualmente, excluída qualquer ligação entre eles, mas constituindo-os em Povo que $\mathrm{O}$ conhecesse na Verdade e $\mathrm{O}$ servisse santamente ${ }^{\$ 698}$, remetendo diretamente ao significado do vocábulo do mysterion, ou seja, "o desígnio de Deus em favor da humanidade", como aparece no primeiro capítulo.

Deus quer construir com um Povo uma relação de Verdade e santidade. Esta compreensão de Povo de Deus está presente amplamente no Antigo Testamento, segundo S. Pié-Ninot, e é uma experiência muito viva, pois nem os dois exílios

\footnotetext{
${ }^{694}$ RATZINGER, J., Obras completas VIII/1, p. 232-239.

${ }^{695}$ PIÉ-NINOT, S., Eclesiología, p. 154.

${ }^{696}$ VITALI, D., Il popolo di Dio, p. 143.

${ }^{697}$ PHILIPS, G., La Chiesa e il suo mistero, p. 56.

${ }^{698}$ CONCÍLIO VATICANO II, Lumen gentium 9.
} 
subsequentes conseguiram apagar. $\mathrm{O}$ povo de Israel guarda e rememora anualmente a Aliança feita como seu Deus e Senhor; foi marcado nas entranhas e no coração como Povo de Deus ${ }^{699}$.

Contudo, segundo D. Vitali, a Constituição Dogmática se centra no novo Povo de Deus, nascido da ação messiânica do Cristo, que é formado por templos do Espírito de Deus, "'raça escolhida, sacerdócio real, nação santa, povo conquistado... que outrora não era povo, mas agora é Povo de Deus' (1Pd 2,9$10)^{, 700}$. Que não era, pois não recebeu o anúncio por parte dos judeus, mas que agora é, pois recebeu por graça de Deus a salvação no Filho, tornando-se nova criatura $^{701}$.

A Igreja só existe porque nela e por ela o Reino de Cristo se manifesta, por ela que a revelação de Deus é comunicada aos homens pela graça, e torna presente em todos os tempos o sacrifício de adoração que o Cristo oferece ao Pai. Como Povo de Deus, a Igreja assume uma identidade dinâmica como romeiro, sempre a caminho, por meio de tentações e tribulações, mas sempre confortada pela força da graça de Deus, que lhe foi prometida pelo Senhor, pois é nele que se alicerça para nunca se afastar da perfeita fidelidade, por causa da fraqueza da carne. Contudo, mantém a dignidade de Esposa de Cristo, sempre renovada pela ação do Espírito Santo, até chegar à luz que não conhece ocaso ${ }^{702}$.

A economia da salvação realizada por Deus em prol do ser humano decaído, segundo A. Grillmeier, abarca a realidade toda: da criação ao fim do mundo, tendo Cristo como evento central. O Filho, "quando se encarnou e se fez homem, recapitulou em si toda a longa série dos homens, dando-nos em resumo a salvação, de forma que o que tínhamos perdido em Adão, isto é, a imagem e semelhança de Deus, o recuperássemos em Jesus Cristo"703.

A recapitulação, no pensamento de Irineu, enquanto ato de Cristo, é uma contribuição especial que Cristo dá à realização da única economia do Pai, em Cristo e no Espírito ${ }^{704}$. Como afima a Lumen gentium no parágrafo nove, com a nação israelita, Deus sela uma Aliança de vida e salvação. Da mesma forma,

\footnotetext{
${ }^{699}$ PIÉ-NINOT, S., Eclesiología, p. 150-151.

${ }^{700}$ CONCÍLIO VATICANO II, Lumen gentium 9.

701 VITALI, D., Il popolo di Dio, p. 156-157.

${ }^{702}$ SEMMELROTH, O., A Igreja: o novo Povo de Deus, p. 482-483; VITALI, D., Il popolo di Dio, p. 159.

${ }^{703}$ IRINEU de Lião, Adversus haereses III, 18, 1.

${ }^{704}$ GRILLMEIER, A., Gesù il risto nella fede della Chiesa, p. 283-284.
} 
revela e anuncia o Cristo, prefigurado no Antigo Testamento, como caminho de fé e de esperança para o seu Povo Eleito.

Entretanto, no Novo Testamento, uma nova realidade enriquece a consciência da fé dos homens em Deus, recebendo em acréscimo o Filho de Deus, de sorte que o homem se torna partícipe de Deus, e também cresce o aperfeiçoamento da conduta ${ }^{705}$. A novidade que o Cristo veio revelar tem como consequência a recapitulação, como afirma Irineu:

Portanto, existe um só Deus Pai, como dissemos, e um só Jesus Cristo, nosso Senhor, que se torna presente por meio de toda a economia e recapitula em si todas as coisas. Neste "todas as coisas" está incluído o homem, criatura de Deus, e, recapitulando em si também o homem, de invisível que era tornou-se visível, de incompreensível, inteligível, de impassível, passível, de Verbo, homem. Recapitulou todas as coisas em si para que Ele, que como Verbo de Deus tem a primazia entre os seres celestes, espirituais e invisíveis, a tivesse também entre os seres visíveis e corporais, e para que, ao assumir em si esta primazia e ao tornar-se cabeça da Igreja, atraísse a si todas as coisas, no tempo oportuno ${ }^{706}$.

É no Cristo, cabeça do Corpo que é a Igreja, segundo A. Benoit e B.

Sesboüé, que o Pai recapitula e reúne seu novo Povo Eleito. Deus inaugura uma Nova Aliança em favor dos homens, diversa da que tinha feito com os pais no monte Horeb, isto é, a fé em Cristo, caminho da justiça aberto no deserto e os rios do Espírito Santo brotados na terra árida, para matar a sede da raça escolhida de Deus, a qual adquirira para que contasse os seus prodígios, e não para insultar a Deus, que fez estas coisas ${ }^{707}$.

A Constituição Dogmática afirma que a Igreja Povo de Deus se destina a abranger todas as regiões, entrar na história dos homens, ao mesmo tempo que transcende os tempos e as fronteiras dos povos. E. Osborn e B. Sesboüé reafirmam a perspectiva totalizante da teologia irineana da recapitulação, porque na obra salvadora de Cristo tudo foi agregado e conduzido ao caminho correto.

Primeiramente, pela criação que retorna ao seu Criador e o ser humano redescobre sua imagem e semelhança com o Senhor, tendo seu ponto fulcral no resgate da possibilidade do ser humano voltar-se para o seu Deus e descobrir que este Deus está sempre com ele. O segundo momento se manifesta na encarnação,

${ }^{705}$ IRINEU de Lião, Adversus haereses IV, 28, 1; GRILLMEIER, A., Gesù il Cristo nella fede della Chiesa, p. 284.

${ }^{706}$ IRINEU de Lião, Adversus haereses III, 16, 6.

${ }^{707}$ IRINEU de Lião, Adversus haereses IV, 33, 14; SESBOÜÉ, B., Tout récapituler dans le Christ, p. 136-138; BENOIT, A., Saint Irénée, p. 219-227. 
morte e ressurreição de Cristo, pois a totalidade manifestada invisivelmente na criação se revela visível e real.

No nascimento de Cristo é recapitulado o nascimento de Adão, a desobediência de Adão é resgatada na obediência de Cristo. Ademais, em sua encarnação e morte, Jesus Cristo reuniu toda a história da salvação e restaurou a imagem e semelhança de Deus no ser humano. Num terceiro e último momento, com o seu retorno glorioso, o Cristo, que é o começo e o fim de tudo, agregará todos ao Deus eterno e amoroso ${ }^{708}$.

Se na Lumen gentium a revolução copernicana foi colocar a Igreja novo Povo de Deus contendo em si a hierarquia, na teologia irineana, a Igreja Povo de Deus ocupa uma discussão cristológica e soteriológica mais ampla. Visto que a certeza de pertença a este novo Povo de Deus nos vem do Verbo de Deus, o qual, na sua encarnação, morte e ressurreição, recapitulou toda a obra da criação nessa nova economia da salvação. Ele também agregou em si tudo e todos, conduzindoos do deserto do sofrimento para onde foram mandados após banidos do Jardim do Éden, para o encontro integrante e integrador com seu Deus e Pai. Deste modo, o Povo de Deus não é somente a hierarquia ou um novo grupo, mas sim todos os que em Cristo receberam vida nova e se voltaram para ouvir e nutrir-se da fonte da vida.

Os parágrafos subsequentes da Constituição Dogmática, de dez a doze, abordam o tema do sacerdócio comum dos fiéis, afirmando que "Cristo Nosso Senhor, Pontífice escolhido de entre os homens ( $\mathrm{Hb} 5,1-5)$, fez do novo Povo um 'Reino Sacerdotal para seu Deus e Pai' $($ Ap 1,6),709. A Igreja é o Povo de Deus, segundo E. De Smedt, homens e mulheres que Cristo utiliza como instrumento para realizar a salvação do mundo inteiro, como luz do mundo e sal da terra.

Jesus Cristo surgiu no mundo como sumo sacerdote, rei e profeta de uma nova Aliança e a Igreja como Corpo de Cristo recebe da cabeça a missão sacerdotal, régia e profética. O Senhor faz do seu Corpo uma comunidade de consagrados; em cada cristão, em cada membro do seu corpo, Cristo faz sua missão prosseguir. Ademais, o sacerdócio comum é o sacerdócio universal, não erroneamente designado sacerdócio dos leigos. É o sacerdócio primordial e

${ }^{708}$ OSBORN, E., Irenaeus of Lyons, p. 115-116; SESBOÜÉ, B., Tout récapituler dans le Christ, p. 129-132.

${ }^{709}$ CONCÍLIO VATICANO II, Lumen gentium 10. 
indispensável a toda consagração posterior, porque outra qualquer participação no sacerdócio de Cristo não é senão o desenvolvimento ulterior desta incorporação fundamental $^{710}$.

Esta Carta Magna da teologia católica sobre o sacerdócio comum de todos os batizados, segundo W. Kasper, resgatou e enfatizou a doutrina bíblica e patrística do sacerdócio comum e conclamou todos a darem testemunho do Evangelho, os quais são chamados à participação plena, consciente e ativa na celebração eucarística ${ }^{711}$. Como Povo de Deus, todos devem se sentir responsáveis pela Igreja. A missão da Igreja foi confiada à totalidade dos fiéis, sujeitos e corresponsáveis, mas com ministérios e carismas diversos, como atestam os textos neotestamentários ${ }^{712}$. "O sacerdócio comum dos fiéis e o sacerdócio ministerial ou hierárquico, embora se diferenciem essencialmente, e não apenas em grau, ordenam-se mutuamente um ao outro; pois um e outro participam, a seu modo, do único sacerdócio de Cristo" 713 .

O exercício do sacerdócio comum dos fiéis se efetiva na comunidade sacerdotal, que vive os sacramentos. "Os fiéis, incorporados na Igreja pelo batismo, são destinados pelo caráter batismal ao culto da religião cristã e, regenerados para filhos de Deus, devem confessar diante dos homens a fé que de Deus receberam por meio da Igreja"714.

A participação ativa dos fiéis na vida eclesial, e principalmente na liturgia, como é mais conhecida a referência a partir do Sacrosanctum concilium, segundo L. Girardi, é um desejo claro da Igreja do nosso tempo. Os fiéis são convocados e formados para uma participação plena, ativa e consciente das celebrações litúrgicas e da comunidade eclesial. Esse desejo não nasce no Concílio Vaticano II; a participação ativa dos fiéis era um sonho de Pio X. A motivação para a participação ativa se apoia na obra de Cristo, sacerdote que conduz seu corpo, o Povo de Deus, e no dever e direito dos cristãos, os quais foram adquiridos por força do batismo $^{715}$.

Prosseguindo, segundo D. Vitali, a Lumen gentium conclui o parágrafo décimo primeiro com a afirmação da importância de cada fiel assumir a vocação

\footnotetext{
${ }^{710}$ DE SMEDT, E., O sacerdócio dos fiéis, p. 486-487.

${ }^{711}$ CONCÍLIO VATICANO II, Sacrosanctum concilio 14.

${ }^{712}$ KASPER, W., A Igreja Católica, p. 262-263.

${ }^{713}$ CONCÍLIO VATICANO II, Lumen gentium 10.

${ }^{714}$ CONCÍLIO VATICANO II, Lumen gentium 11.

${ }^{715}$ GIRARDI, L., Sacrosanctum concilium, p. 115-117.
} 
universal à santidade, de todos os membros do Povo de Deus. "Munidos de tantos e tão grandes meios de salvação, todos os fiéis, seja qual for a sua condição ou estado, são chamados pelo Senhor à perfeição do Pai, cada um por seu caminho"716.

Da teologia irineana sobre o Batismo ${ }^{717}$ se apreende uma compreensão da teologia do sacerdócio comum dos fiéis como membros do novo Povo de Deus. O Batismo, para Irineu, confere aos cristãos a fé e, por meio dela, quem adentrar no tesouro sagrado da tradição apostólica, da regula fidei, das práticas e experiências cristãs, deixa de ser um homem velho, para se torna um ser humano novo pelo banho na água que perdoa os pecados e pela unção do Espírito que lhe dá vida nova.

O batismo marca, para o bispo de Lião, o ingresso neste novo Povo de Deus, porque "o Batismo é o selo da Vida Eterna, o novo nascimento em Deus, de modo que já não somos mais filhos de homens mortais, mas do Deus eterno e indefectível" ${ }^{718}$, assim participa-se da recapitulação iniciada em Cristo. O poder e a graça de Deus manifestam-se sobre os que são de Deus, não sobre os outros.

Contudo, seria possível pensar numa perspectiva exclusivista da teologia irineana? Ao contrário, pois não se pode deixar de levar em conta que Deus criou o homem com as suas próprias mãos, tomando da terra o que existia de mais puro e mais fino, e misturando, na medida certa, a sua potência. De fato, traçou sobre o ser humano modelado a imagem divina, porque, como imagem de Deus, o homem foi plasmado e colocado na terra, e lhe deu a vida soprando sobre o seu rosto o hálito vital, de modo que, no espírito e no físico, o homem fosse semelhante a ele $^{719}$. "Com efeito, Deus é a glória do homem e o homem é o receptáculo da obra, de toda a sabedoria e do poder de Deus" ${ }^{\text {"720 }}$. Todos receberam do Criador a vida, porém foram criados autônomos e livres para submeterem a criação e construírem seu caminho de vida.

Além disso, a reagregação do ser humano, num novo Povo de Deus, fora necessária para que todos os homens e mulheres pudessem descobrir a maravilha das suas vidas e reconhecer seu Senhor e Criador.

${ }^{716}$ CONCÍLIO VATICANO II, Lumen gentium 11; VITALI, D., Il popolo di Dio, p. 174.

${ }^{717}$ Como dito acima, p. 113-117.

${ }^{718}$ IRINEU de Lião, Epideixis 3.

${ }^{719}$ IRINEU de Lião, Epideixis 10.

${ }^{720}$ IRINEU de Lião, Adversus haereses III, 20, 2. 
Os valentinianos almejavam resgatar os pneumáticos para a gnose - os conhecimentos escondidos sobre o Pleroma -, para assim reconduzirem os que eram do mundo espiritual à sua origem. Irineu não somente denuncia este fato, como também refuta essas propostas gnósticas, mostrando que a recapitulação de Cristo resgatou toda obra criada e abriu um novo caminho de justiça no deserto e rios do Espírito na terra árida para matar a sede da raça escolhida de Deus, os quais Ele adquiriu para narrar os seus prodígios.

É o vinho novo que se põe nos odres novos ${ }^{721}$; e este vinho novo, segundo Irineu, é a verdadeira gnose, que é a doutrina dos apóstolos. Quer dizer, a conservação fiel das Escrituras que chegou até nós, a explicação integral dela, sem acréscimos ou subtrações, a leitura isenta de fraude e em plena conformidade, a qual a Igreja difunde pelo mundo todo, onde estiver, pois este é o caráter distintivo do Corpo de Cristo que se reúne para louvar, reverenciar e servir ao seu Criador e Senhor. Portanto, o mais importante é o dom da caridade, mais precioso do que a gnose, mais glorioso do que a profecia, superior a todos os outros carismas $^{722}$.

Irineu não utiliza a expressão sacerdócio comum dos fiéis para se referir aos batizados, como o faz a Lumen gentium, visto que reserva os vocábulos sacerdócio e sacerdote para se referir aos descendentes de Aarão, no Antigo Testamento $^{723}$, ao múnus de Cristo ${ }^{724}$ e aos apóstolos, como sacerdotes sem casa nem campos em herança, mas que servem o altar $^{725}$. Porém, em Jesus Cristo sacerdote, profeta e rei, todos recebem a regeneração, e participam da economia da salvação, deixando de ser oliveira bravia, abandonada no deserto árido, para se tornar oliveira fértil.

Não se perde a substância da sua matéria, disse Irineu, muda-se a qualidade dos frutos e recebe o nome de oliveira fértil: "assim, o mesmo se verifica no homem que é enxertado pela fé e recebe o Espírito de Deus; não perde a natureza da carne, e sim muda a qualidade dos frutos, porque não é mais chamado carne e sangue, e sim homem espiritual”, ${ }^{, 726}$. O sacerdócio comum dos fiéis, em Irineu de Lião, aparece neste novo enxerto de vida, que se recebe pelo dom do Espírito.

\footnotetext{
${ }^{721}$ IRINEU de Lião, Adversus haereses IV, 33, 14.

${ }^{722}$ IRINEU de Lião, Adversus haereses IV, 33, 8.

${ }^{723}$ IRINEU de Lião, Epideixis 26.

${ }^{724}$ IRINEU de Lião, Epideixis 47-48.

${ }^{725}$ IRINEU de Lião, Adversus haereses IV, 8, 3.

${ }^{726}$ IRINEU de Lião, Adversus haereses V, 10, 2.
} 
Recapitulados em Cristo como novo Povo de Deus, recebem a missão de sacerdotes, profetas e reis, para serem, na Igreja e no mundo, sinal da presença do Cristo.

A Constituição Dogmática interrompe a explanação sobre o sacerdócio comum dos fiéis e retoma a explanação sobre a Igreja Povo de Deus, segundo D. Vitali, composta por outra subcomissão criada no segundo período do Concílio, durante as discussões do esquema De Ecclesia, quando houve a alteração da ordem dos capítulos. Um dos membros dessa nova subcomissão era o padre Yves Congar, grande influenciador e redator de quase todos os parágrafos subsequentes $(13-16)^{727}$.

O parágrafo treze inicia afirmando que, ao novo Povo de Deus, todos os homens são chamados, pois foram criados como uma única humanidade, a qual, como Povo, deve se estender a todo o mundo e por todos os séculos, porque somente assim cumprirá a vontade do Criador, que, no princípio, criou uma só natureza humana e resolveu juntar em unidade todos os seus filhos, que estavam dispersos. O Filho foi enviado como herdeiro de todas as coisas e foi constituído como cabeça do novo Povo dos filhos de Deus e o Espírito foi enviado para ser "princípio de agregação e de unidade na doutrina e na comunhão dos apóstolos, na fração do pão e na oração". ${ }^{728}$

Esta primeira parte do décimo terceiro parágrafo está em estreita unidade e complementariedade com o parágrafo nono, início deste capítulo, pois a ação de Deus acontece em dois momentos, os quais manifestam sua vontade salvífica: na criação, nos inícios, e na nova criação, ou recapitulação de todas as coisas, em Cristo.

Aqui é apresentada uma referência a Irineu de Lião, nas notas de rodapé, de dois textos - Adversus haereses III, 16, 6 e III, 22, 1-3 - que resgatam os mistérios da vida do Cristo: encarnação no ventre virginal de Maria, revelação do Pai na sua pregação e nos sinais, paixão, morte e ressureição como parte da economia da salvação, e, finalmente, como aquele que na sua ascensão reina no céu como cabeça universal da Igreja ${ }^{729}$.

\footnotetext{
${ }^{727}$ VITALI, D., Il popolo de Dio, p. 187.

${ }^{728}$ CONCÍLIO VATICANO II, Lumen gentium 13.

${ }^{729}$ GIANOTTI, D., I Padri della Chiesa al concilio Vaticano II, p. 309.
} 
Irineu $^{730}$ apresenta a recapitulação como fundamental para a constituição da Igreja, visto que ela é parte da economia da salvação do Pai, que, a partir da encarnação do Verbo, reúne nela os que foram recapitulados pelo Filho.

A universalidade da Igreja, segundo G. Lopes, está manifesta em cada uma das igrejas locais, que estão presentes em todo o mundo, nas regiões e culturas mais diversas, porque o Povo de Deus pertence a todos os povos da terra. Estando presente numa determinada sociedade humana, esse Povo nada perde das suas riquezas, mas sim oferece e recebe riquezas, bem como o modo de ser de cada povo. Logo, existem diversidades entre os membros, quer em funções, em ministérios, em estado e condições de vida, "por isso que na comunhão eclesial existem legitimamente igrejas particulares com tradições próprias, sem detrimento do primado da cátedra de Pedro, que preside à universal assembleia da caridade" ${ }^{731}$. Ademais, no seu múnus de pastor legítimo cabe proteger as diversidades e vigiar para que as particularidades ajudem a unidade e não a prejudiquem $^{732}$.

E. Zoghby afirma que a universalidade e a unidade da Igreja não são um dom divino ou uma qualidade acrescentada na Igreja, mas sim um processo de se construir, agregar-se, porque o templo de Deus se constrói somando cada uma das pedras desse edifício (1Pd 2,5), que é a Igreja. O Corpo de Cristo é construído pela fé de cada pedra ali depositada; assim, a Igreja se deve unir na medida que se constrói ${ }^{733}$.

Irineu $^{734}$ afirma que toda criatura é templo de Deus ${ }^{735}$, visto que no seu corpo habita o Espírito de Deus. E como templos de Deus, tornam-se pedras do edifício do Senhor, que é o Cristo. Cada fiel é membro desse edifício, pois ao deixar-se moldar pelo Espírito e pelo Verbo - a pedra angular - ajeita-se hermeticamente ao edifício, formando, assim, com os demais, uma unidade construída pela graça de Deus derramada no ser humano - Espírito Santo - e pela identificação com o Cristo, cabeça do Corpo que é a Igreja.

Nos parágrafos subsequentes, 14 a 16, a catolicidade da Igreja como único Povo de Deus aparece, segundo D. Vitali, do ponto de vista dos diversos graus de

\footnotetext{
${ }^{730}$ Como dito acima, p. 93; 108-109.

${ }^{731}$ CONCÍLIO VATICANO II, Lumen gentium 13.

${ }_{732}^{732}$ LOPES, G., Lumen gentium, p. 60-61.

${ }^{733}$ ZOGHBY, E., Unidade e diversidade da Igreja, p. 558-559.

${ }^{734}$ Como dito acima, p. 39-43; 107.

${ }^{735}$ IRINEU de Lião, Adversus haereses V, 6, 2.
} 
pertença à Igreja: dos católicos aos nãos católicos, e finaliza com os não cristãos. Une-se à teologia irineana de que todos são templos do Senhor, não precisando de serem despertos para a gnose, como queriam os valentinianos, mas sim para o conhecimento do Cristo e acolhida da Boa Nova que Ele nos trouxe, juntamente com a graça do Espírito, que sela a todos com o sigilo da Vida Eterna no Pai.

O capítulo segundo da Lumen gentium finaliza, no décimo sétimo parágrafo, com a reflexão sobre o caráter missionário da Igreja, segundo D. Vitali, o qual não aborda o tema da missão em si, contudo da missão da Igreja, como de uma dimensão eclesial constitutiva, que aprofunda ainda mais a natureza do Povo de Deus.

Essa reflexão se iniciou no segundo período do Concílio e foi sendo gestada dentro das discussões entre os padres conciliares e as Subcomissões, principalmente porque os padres estavam incomodados com o esquema $D e$ Missionibus, que trazia uma perspectiva muito fechada da atividade missionária da Igreja $^{736}$.

Contudo, a missão da Igreja presente na Constituição Dogmática não provém do Cristo diretamente, mas sim dos apóstolos, que receberam do Senhor a ordem de anunciar o Evangelho - como nos tempos passados fora pedido aos profetas. Destes apóstolos e varões apostólicos a Palavra chegou aos confins da terra, quer por pregação oral, quer por obras e instituições, ou ainda por textos escritos. "Porém, para que o Evangelho fosse perenemente conservado íntegro e vivo na Igreja, os apóstolos deixaram os bispos como seus sucessores, entregando-lhes o seu próprio ofício de magistério".

Tal compreensão, segundo D. Vitali, nasce no Concílio, a partir da hermenêutica histórico-crítica das Sagradas Escrituras - principalmente dos dois textos que fundamentam esse parágrafo - Jo 20,21 e Mt 28,19-20 -, que afirmava que a missão dada à Igreja nos Evangelhos é fruto de uma elaboração da comunidade Cristã pós-pascal. Dessa forma, afirmava que a Igreja recebeu sua missão não somente dessas duas palavras, mas principalmente da pregação dos apóstolos, a qual constituiu na Igreja a modalidade fundamental de transmissão da revelação.

\footnotetext{
${ }^{736}$ VITALI, D., Il popolo de Dio, p. 204-205; LE GUILLOU, M.-J., A vocação missionária da
} Igreja, p. 713. 
Portanto, o parágrafo décimo sétimo inicia afirmando que, "assim como o Filho foi enviado pelo Pai, assim também Ele enviou os apóstolos. A Igreja recebeu dos apóstolos este mandato solene de Cristo, de anunciar a Verdade da salvação e de a levar até aos confins da terra"737.

Por conseguinte, segundo M. J. Le Guillou, três pontos são fundamentais para se referir à vocação missionária da Igreja. Primeiro, como já apresentado acima, a missão nasce na missão do Filho de Deus encarnado, e é a partir dele e seguindo o que viveu e anunciou que os apóstolos iniciaram a evangelização, guiados e impulsionados pelo Espírito de Deus. Dos apóstolos a Igreja recebe o mandato e do Espírito, a iluminação para a atividade missionária. Em segundo lugar, a atividade missionária deve ser um caminho de construção com os povos evangelizados, assumindo e reforçando a cultura de cada povo e sua forma de viver, como base para anunciar a Boa Nova de Jesus Cristo. E, por fim, todos os fiéis participam do mandato missionário confiado à Igreja: "a todo o discípulo de Cristo incumbe o encargo de difundir a fé, segundo a própria medida"738.

A Lumen gentium, mesmo de forma breve, somente no número dezessete inaugurou uma virada na teologia da missão, visto que os padres conciliares não partiram nem da salvação das almas e nem da implantação de igrejas para refletir sobre a missão. Ao contrário, segundo W. Kasper, como a Igreja é sinal e instrumento, a missão precisa valorizar o caráter trinitário, cristológico e pneumatológico. Em outros termos, o envio do Filho pelo Pai, que pelo Espírito em Pentecostes envia os discípulos, que receberam a ordem de Cristo, marca o ponto de partida central da missão na Constituição Dogmática: o amor fontal de Deus, que enviou o Filho e o Espírito, para que a obra salvífica começasse no âmago da pessoa. A Igreja é sacramento da salvação, sinal e instrumento de íntima relação e união entre Deus e a humanidade ${ }^{739}$.

Os objetivos fundamentais de Irineu com os livros da Adversus haereses são denunciar as teorias gnósticas e refutar essas doutrinas, tendo por base a Sagrada Escritura. Partindo desse breve resumo, pode-se afirmar somente o caráter apologético da obra irineana, sem perceber nela nenhum intuito de resgatar os que estão no erro.

${ }^{737}$ CONCÍLIO VATICANO II, Lumen gentium 17.

${ }^{738}$ CONCÍLIO VATICANO II, Lumen gentium 17; LE GUILLOU, M.-J., A vocação missionária da Igreja, p. 713-722.

${ }^{739}$ KASPER, W., A Igreja Católica, p. 366-367. 
Entretanto, ao ler a Adversus haereses por várias vezes, o bispo de Lião deixa transparecer seu múnus de pastorear e conduzir o rebanho que se perdeu: "anuímos ao teu pedido, porque somos encarregados do ministério da Palavra, por apresentar-te o maior número possível de subsídios para contrabater os hereges, converter os que se afastaram e reconduzi-los à Igreja de Deus" ${ }^{\text {740 }}$. E, ainda, "conforme o teu pedido, tenhas, de nossa parte, todos os meios para refutar os hereges e, derrotados, não os deixes afundar no abismo do erro, mas dirigindo-os ao porto da Verdade, os faças chegar à salvação" "741. Ao que foi encarregado da palavra, a missão é instruir e anunciar, assim como orientar, pastorear e conduzir ao caminho correto. Além disso, o anúncio não deve ser sinal de derrota e humilhação, mas deve mostrar a verdade que conduz à salvação.

Sendo assim, diferente de uma imagem de heresiólogo, quase um juiz do Santo Ofício, Irineu se insere no seu tempo, numa Igreja que precisa defender e dar aos fiéis a clareza dos argumentos verdadeiros e da doutrina. Por isso, o bispo se baseia sempre na regula fidei como único princípio de verdade e base para compreensão das Escrituras, mas sempre tendo consciência de que todos foram criados por Deus, e devem o conhecer, por meio do Filho, deixando-se iluminar pelo Espírito.

Dessa forma, Irineu incentiva a comunidade a rezar pelos que estão no erro, para que não permaneçam na fossa que cavaram para si mesmos, afastando-se do erro e das trevas, para descobrirem pela graça do Espírito que são filhos, no Filho que os resgatou, e conheçam o Criador e o Autor deste universo como único verdadeiro Deus, Senhor de todas as coisas. "Esta é a nossa oração para eles e com isso os amamos. O nosso amor, sendo verdadeiro, lhes é proveitoso se o aceitarem. Por isso não nos cansamos e continuaremos a estender-lhes as mãos" ${ }^{, 742}$.

A referência à obra de Irineu neste parágrafo cita um trecho da Adversus haereses III, 17, 5, que remete à profecia de Ml 1,10-11, na qual o profeta amaldiçoa a oferenda feita por Israel e elogia as oferendas apresentadas pelas nações do Oriente ao Ocidente, pois são sacrifícios e oblações puras. Irineu interpreta esse trecho em relação à Eucaristia que a Igreja celebra, oferecendo a

\footnotetext{
${ }^{740}$ IRINEU de Lião, Adversus haereses V, prefácio.

${ }^{741}$ IRINEU de Lião, Adversus haereses IV, prefácio, 1.

742 IRINEU de Lião, Adversus haereses III, 25, 7.
} 
Deus em todos os lugares um sacrifício e uma oblação de louvor e adoração. $O$ texto não remete ao fundamental apresentado no parágrafo: a índole missionária da Igreja.

\subsection{3.}

\section{Episcopado e sucessão apostólica}

A nova visão teológica sobre o ministério ordenado na Igreja, que o capítulo terceiro da Lumen gentium apresenta, deve ser lida e compreendida a partir da correlação com o que foi exposto no capítulo anterior, sobre a Igreja novo Povo de Deus, visto que o ministério ordenado, segundo S. Noceti, primeiramente é pensado como serviço na Igreja e para a Igreja povo sacerdotal e comunidade carismática. Além disso, todos os batizados são chamados ao serviço dos irmãos na caridade e reconhecidos como sujeitos participantes da missão eclesial, portadores de uma palavra necessária na proclamação da fé e na compreensão do Evangelho $^{743}$.

Cristo Nosso Senhor, para apascentar e aumentar continuamente o Povo de Deus, instituiu na Igreja diversos ministérios, para bem de todo o corpo. Com efeito, os ministros que têm o poder sagrado servem os seus irmãos para que todos os que pertencem ao Povo de Deus, e por isso possuem a verdadeira dignidade cristã, alcancem a salvação, conspirando livre e ordenadamente para o mesmo fim $^{744}$.

O discurso do papa Paulo VI em ocasião da abertura do terceiro período do Concílio Vaticano II trata enfaticamente deste terceiro capítulo da Lumen gentium, pois o pontífice afirma que é preciso "explicar o pensamento de Cristo sobre a sua Igreja toda, e especialmente sobre a natureza e função dos sucessores dos apóstolos, isto é, do episcopado, cuja dignidade e cargo a maior parte de vós recebestes por benigna disposição de Deus" ${ }^{\text {"745 }}$. Para tanto, evoca a continuidade do Concílio Vaticano I, que começou a refletir sobre o assunto, porém tratou somente do tema do romano pontífice, especialmente sobre a infalibilidade papal.

Por outro lado, afirma D. Vitali, um século depois, o tema do primado papal e do episcopado já havia sido discutido em outras vertentes e amadurecido

\footnotetext{
${ }^{743}$ NOCETI, S., La costituzione gerarchica della Chiesa e in particolare l'episcopato, p. 215.

${ }^{744}$ CONCÍLIO VATICANO II, Lumen gentium 18.

${ }^{745}$ PAULO VI, Discurso do papa Paulo VI na inauguração da terceira sessão do Concílio Ecumênico Vaticano II.
} 
teologicamente. Mesmo assim, será na esteira do Vaticano I que o Vaticano II desenvolverá o tema dos ministérios, ordenados em doze parágrafos ${ }^{746}$.

Dessa forma, o parágrafo dezoito inicia o capítulo terceiro retomando as discussões do Vaticano I sobre a doutrina do primado, ao afirmar que "para que o mesmo episcopado fosse uno e indiviso, colocou o bem-aventurado Pedro à frente dos outros apóstolos e nele instituiu o princípio e fundamento perpétuo e visível da unidade de fé e comunhão" ${ }^{, 74}$. Entretanto, no parágrafo dezenove, os padres conciliares fundamentam a vocação hierárquica da Igreja sobre o mandato e a instituição dos doze apóstolos e, no parágrafo vinte, colocam os bispos como sucessores diretos deles. Com isso, retomam a teologia patrística dos três primeiros séculos, que afirmava o episcopado não a serviço do papa, mas sim como mandato do próprio Senhor.

Uma das partes mais importantes do capítulo terceiro é a reflexão sobre a sacramentalidade do episcopado. No parágrafo vinte e um, "estes pastores, escolhidos para apascentar o rebanho do Senhor, são ministros de Cristo e dispensadores dos mistérios de Deus... juntamente com o poder de santificar, confere também os poderes de ensinar e governar,"748. No entanto, os epíscopos só podem exercer suas funções em comunhão hierárquica com a cabeça e os membros do colégio episcopal, sobre o qual a Lumen gentium tratou nos dois parágrafos subsequentes, enfatizando a função do colégio episcopal, sua relação com o romano pontífice e suas relações entre si.

Nesta parte, há uma passagem delicada do terceiro período do Concílio, pois uma minoria de padres conciliares reivindicou junto a Paulo VI que fosse elaborada a famosa nota explicativa prévia, composta de quatro parágrafos, especificando que o colégio dos Bispos nunca pode ser entendido sem o papa, mas sempre cum Petro et sub Petro.

Ademais, dos parágrafos vinte quatro a vinte e sete, a Constituição Dogmática apresenta o ministério dos bispos, especificando o múnus de ensinar, “dotados da autoridade de Cristo, são doutores autênticos, que pregam ao Povo a eles confiado a fé que se deve crer e aplicar na vida prática"; de santificar, "pelo ministério da Palavra, comunicam a força de Deus, para salvação dos que creem e,

\footnotetext{
${ }^{746}$ NOCETI, S., La costituzione gerarchica della Chiesa e in particolare l'episcopato, p. 209-210; VITALI, D., Lumen gentium, p. 77-78.

${ }^{747}$ CONCÍLIO VATICANO II, Lumen gentium 18.

${ }^{748}$ CONCÍLIO VATICANO II, Lumen gentium 21.
} 
por meio dos sacramentos, cuja distribuição regular e frutuosa ordenam com a sua autoridade, santificam os fiéis"; de reger, "os bispos governam as igrejas particulares como vigários e legados de Cristo, por meio de conselhos, persuasões, exemplos, mas também com autoridade e poder sagrado, que exercem unicamente para edificar o próprio rebanho na Verdade e na santidade"749.

Nos últimos dois parágrafos do capítulo é tratado o tema dos presbíteros, que ocupam o segundo grau da ordem, e sua relação com Cristo, com o bispo, os outros presbíteros e o Povo cristão. Além deste, aparece o tema do diaconato: "aos quais foram impostas as mãos 'não em ordem ao sacerdócio, mas ao ministério'... e que poderá este diaconato ser conferido a homens de idade madura, mesmo casados, e a jovens idôneos"

A descoberta do caráter colegiado do episcopado, segundo U. Betti, representa um dos elementos de novidade na compreensão do Vaticano II, e tem todas as credenciais para ser considerado um progresso real da eclesiologia. Posto isto, ela apresenta o episcopado numa organização mais harmônica e unida, assemelhando-se à sua original instituição, que foi o colégio Apostólico, instituído por Cristo.

Se bem compreendido na letra e no espírito, o Concílio quis dar à colegialidade episcopal o significado e o valor que Cristo conferiu aos seus discípulos, quando, após rezar ao Pai, chamou os que quis para permanecerem com Ele e para os enviar a pregar o Reino de Deus, sempre em comunhão e no obséquio com o que é o primeiro entre eles, Pedro ${ }^{751}$.

J. Ratzinger afirma que fica inequivocamente expresso que o colégio dos Bispos não tem no papa sua origem nem sua dependência essencial, mas provém de uma realidade sacramental, originando-se da própria natureza da Igreja. Porém, a comunhão com o chefe e com o restante dos membros do colégio é que garante a efetiva pertença a este. Dessa forma, a perspectiva sacramental do episcopado retira o foco da perspectiva jurídica da alta escolástica, para receber novamente a luz original da teologia dos Santos Padres ${ }^{752}$.

\footnotetext{
${ }^{749}$ CONCÍLIO VATICANO II, Lumen gentium 25-27.

${ }^{750}$ CONCÍLIO VATICANO II, Lumen gentium 29; VITALI, D., Lumen gentium, p. 79; NOCETI, S., La costituzione gerarchica della Chiesa e in particolare l'episcopato, p. 215-220.

${ }_{751}$ BETTI, U., Relações entre o papa e os outros membros do colégio episcopal, p. 789-799.

752 RATZINGER, J., A colegialidade dos Bispos, p. 770-771.
} 
Outro ponto a ser reforçado sobre a colegialidade na Lumen gentium é a importância da comunhão, que no seu sentido espiritual reforça a formação da comunidade dentro e ao redor do Corpo de Cristo, comunhão hierárquica para sustentar a comunhão eclesial. No entanto, o episcopado não pode se conformar somente com a dimensão cúltica e institucional. O Concílio Vaticano II resgatou a perspectiva mais fortemente pastoral e missionária, fundamento essencial do mandanto de Cristo aos apóstolos, como descrito no parágrafo dezenove ${ }^{753}$.

Esta nova visão da teologia dos ministérios ordenados, que emerge no Concílio Vaticano II, tem sua fonte numa leitura pontual dos textos do Novo Testamento, uma melhor consciência das fontes litúrgicas e a recuperação da tradição Patrística dos três primeiros séculos do cristianismo. Especificamente, a afirmação conciliar de que o episcopado é a plenitude do sacramento da ordem é um exemplo desse resgate das fontes primeiras da fé como fundamento da nova compreensão proposta.

Tendo isso em vista, na teologia irineana sobre o ministério episcopal, destacam-se os temas: a tradição apostólica, a igreja de Roma de origem excelente, a relação entre os bispos das igrejas, a sucessão apostólica. A Constituição Dogmática faz referência direta ao pensamento de Irineu, no capítulo terceiro, sobre a tradição apostólica: "e assim, como testemunha Santo Irineu, a tradição apostólica é manifestada em todo o mundo (Adversus haereses III, 3, 1) e guardada (Adversus haereses III, 2, 2; IV, 26, 2; IV, 33, 8) por aqueles que pelos apóstolos foram constituídos bispos e seus sucessores"754.

Para Irineu de Lião, a tradição apostólica ${ }^{755}$ é um critério de autoridade para a comunidade cristã ${ }^{756}$, o que fundamentava e autenticava o modo de vida dos cristãos. Isso porque, recebidos dos apóstolos por descendência natural, estes ensinamentos, práticas, costumes, formas de vida, testemunhos alicerçavam e estruturavam a comunidade Eclesial ali constituída.

Por isso, onde existisse uma comunidade Cristã, as características do cristianismo existiam ali, não de forma uniforme e estática, mas se inserindo na cultura de cada povo evangelizado e na dinamicidade do Espírito que enviou os

753 RATZINGER, J., A colegialidade dos Bispos, p. 768-772; SEMERARO, M., Collegialità episcopale e primato al Vaticano II, p. 135-151.

${ }^{754}$ CONCÍLIO VATICANO II, Lumen gentium 20.

${ }^{755}$ Como dito acima, p. 126-129.

${ }^{756}$ FANTINO, J., La théologie d'Irénée, p. 29-34. 
apóstolos por primeiro e impulsiona a Igreja sempre para evangelizar todos os povos.

Somando-se a isto, para Irineu, a "tradição que vem dos apóstolos é

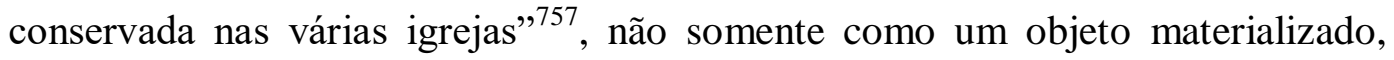
mas principalmente como a verdadeira gnose, que é a doutrina dos apóstolos difundida pela Igreja em todo o mundo; é isso que distingue o Corpo de Cristo. Por conseguinte, está materializada nas Escrituras que a comunidade conserva com fidelidade, e também presente nos ensinamentos e pregações orais, que, em virtude de seguirem a regula fidei, são isentos de fraude e em plena conformidade. Apesar disso, o que de mais importante a tradição apostólica conserva é o dom da caridade, mais precioso que todo conhecimento, que toda profecia e superior a todos os outros carismas ${ }^{758}$.

Outra referência a Irineu, porém não à sua obra, e sim ao seu Ministério episcopal, está na nota cinquenta e nove, no parágrafo vinte e dois sobre o colégio dos bispos e sua cabeça, quando os padres conciliares se referem a Eusébio de Cesareia $^{759}$, no livro cinco, capítulo vinte e quatro. Esse texto narra sobre os bispos da Ásia, sob a direção de Polícrates, escrevendo a Vítor, bispo de Roma, a respeito das questões em torno da data da Páscoa. Eles indagavam se a data deveria ser celebrada no quatorze de Nisan ou no domingo próximo a este dia.

As igrejas da Ásia, como narra Eusébio, afirmam: "quanto a nós, celebramos exatamente o dia, sem nada cortar, nada acrescentar" e se fundamentam em várias e antiquíssimas testemunhas das igrejas na Ásia. Vítor se decidiu por afastar globalmente as igrejas da Ásia da unidade comum. A isso segue a referência da Lumen gentium: "mas isto não aprouve a todos os bispos. Eles aconselharam, ao contrário, solicitude pela paz, união com o próximo e caridade. Opuseram-se a Vítor de modo muito incisivo"

Surge, então, a referência a Irineu, que, como bispo da Gália, no intermédio entre o Oriente - visto que era natural de Esmirna - e o Ocidente - porque era bispo da Gália - decide-se por estabelecer relações diplomáticas entre as igrejas.

Dos parágrafos onze a dezoito, Eusébio narra a intervenção de Irineu, que escreve em nome da sua igreja, ou melhor, "em nome dos irmãos que ele dirigia

\footnotetext{
${ }^{757}$ IRINEU de Lião, Adversus haereses III, 2, 2.

${ }^{758}$ IRINEU de Lião, Adversus haereses IV, 33, 8.

${ }^{759}$ EUSÉBIO de Cesareia, História Eclesiástica V, 24, 1-18.

${ }^{760}$ EUSÉBIO de Cesareia, História Eclesiástica V, 24, 10.
} 
na Gália", primeiro afirmando que somente no domingo se deve celebrar o mistério da ressurreição do Senhor. Em seguida, "exorta delicadamente Vítor a não apartar da comunhão igrejas de Deus inteiras, que conservam a tradição de antigo uso" $" 761$.

Entre os argumentos, Irineu retoma sua viagem a Roma, anos antes, acompanhando Policarpo, bispo de Esmirna, para discutir com Aniceto a mesma questão da data da Páscoa. Assim, ele retoma não só a importância da tradição que fora deixada pelos antepassados de testemunho ilibado, mas também reforça a importância da paz e da concórdia entre as igrejas.

Eusébio confirma que Irineu, carregando no nome o título de pacificador, sempre se entretinha em escrever epístolas para intermediar e exortar outros irmãos epíscopos sobre questões diversas e assim conservar a paz e a concórdia entre as igrejas ${ }^{762}$.

A colegialidade episcopal, para Irineu, brota da rocha, que é o Cristo. Do seu coração, fendido como a rocha fendida por Moisés no deserto, correram doze fontes de água, que são a doutrina dos doze apóstolos, que transmitiram à Igreja $^{763}$.

Os apóstolos confiaram as igrejas para os bispos, cujos caminhos percorrem o mundo inteiro, conservando a sólida tradição que vem dos apóstolos. Ensinam, pregam, exortam, refutam, mostrando sempre uma fé idêntica, porque todos acreditam no mesmo Deus Pai, admitem a mesma economia da encarnação do Filho de Deus, reconhecem o mesmo dom do Espírito, observam os mesmos preceitos, conservam a mesma forma de organização da Igreja, esperam a mesma vinda do Senhor e a mesma salvação de todo o homem. A unidade das igrejas e dos bispos se mostra na forma que vivem e testemunham a fé, não ainda por uma legislação ou doutrina específica, mas sim pelo mandato do Cristo aos apóstolos e pela força do Espírito que impulsiona toda a Igreja ${ }^{764}$.

A excelência na origem da igreja de Roma é exaltada por Irineu, quando trata da sucessão apostólica ${ }^{765}$ : "limitar-nos-emos à maior e mais antiga e conhecida por todos, à igreja fundada em Roma, pelos dois gloriosíssimos

\footnotetext{
${ }^{761}$ EUSÉBIO de Cesareia, História Eclesiástica V, 24, 11.

${ }^{762}$ RATZINGER, J., A colegialidade dos Bispos, p. 770-771.

${ }^{763}$ IRINEU de Lião, Epideixis 47.

${ }^{764}$ IRINEU de Lião, Adversus haereses V, 20, 1; DEJAIFVE, G., A colegialidade episcopal na tradição Latina, p. 860-869.

${ }^{765}$ Como dito acima, p. 129-131.
} 
apóstolos, Pedro e Paulo... com efeito, deve necessariamente estar de acordo com ela, por causa da sua origem mais excelente" ${ }^{\text {766 }}$. Percebe-se, segundo D. Single, o destaque e grandeza da igreja de Roma, na citação de Irineu, visto que remete aos apóstolos e mártires Pedro e Paulo, e por ser alicerçada sobre duas colunas da Igreja. Deste modo, a fundação da comunidade Cristã romana é mais excelsa.

E o martírio de Pedro e Paulo em Roma simboliza, para Irineu, a marca divina da autenticidade apostólica. Como também Clemente Romano irá exaltar os outros mártires romanos, frutos da perseguição no final do século primeiro, texto que Irineu conhece e cita ${ }^{767}$.

Por que uma importância tamanha ao martírio? "Isso vem do fato de que ele representa o critério supremo da autenticidade cristã. O martírio é o único sinal absoluto do testemunho evangélico" ${ }^{\text {768 }}$. Continua a autora: os testemunhos da palavra viva anunciada e da entrega total da vida marcam essa excelência na igreja de Roma; não há uma visão jurídica de transmissão de poder.

O peso da autoridade da igreja de Roma está mais na fé que no poder; mais no exemplo e no testemunho, do que na jurisdição. A igreja de Roma é considerada como a excelente, pelo grande e glorioso testemunho de fé de Pedro e Paulo, e de tantos outros irmãos, dos quais ela foi o lugar e se mantém como $\operatorname{guardiãa}^{769}$.

Numa outra direção, E. Osborn afirma que a excelência da igreja de Roma se funda na obra testemunhada por Pedro e Paulo, ou melhor, pela pregação, pelo ensino da verdadeira revelação, pelo serviço da caridade, pela forma de vida, pela fé vivificante, pela sucessão e tradição que deixaram. Irineu não atribui prioridade a Roma, mas destaca que "nela sempre foi conservada, de maneira especial, a tradição que deriva dos apóstolos" ${ }^{\text {,770. }}$.

\subsection{4.}

\section{Vocação à santidade universal}

O chamado à santidade, como afirma o capítulo quinto da Lumen gentium, é uma condição a que são convocados todos os membros do Povo de Deus pela

\footnotetext{
${ }^{766}$ IRINEU de Lião, Adversus haereses III, 3, 2.

${ }^{767}$ IRINEU de Lião, Adversus haereses III, 3, 3.

${ }^{768}$ SINGLES, D., A glória de Deus é o homem vivo, p. 149.

${ }^{769}$ SINGLES, D., A glória de Deus é o homem vivo, p. 147-153

${ }^{770}$ IRINEU de Lião, Adversus haereses III, 3, 2; OSBORN, E., Irenaeus of Lyons, p. 128-129.
} 
força do Batismo, e não somente os consagrados em razão da observância dos conselhos evangélicos 771 . "A nossa fé crê que a Igreja, cujo mistério o Sagrado Concílio expõe, é indefectivelmente santa. Por isso, todos na Igreja, quer pertençam à hierarquia, quer por ela sejam pastoreados, são chamados à santidade" 772 . Se as discussões internas na subcomissão questionavam a não existência de um capítulo separado sobre $A$ vocação de todos à santidade na Igreja, o próprio texto do capítulo se autojustifica. A santidade não é somente para os religiosos ou para grupos específicos, pois o Espírito de Deus age na Igreja e chama a todos para um único caminho de santidade.

Portanto, é necessário que conservem e aperfeiçoem a santidade que receberam de Cristo e do Espírito no batismo. Assim, a graça divina é fundamental para guardar a santidade e aperfeiçoar-se neste caminho. A Igreja e toda a vida cristã aparecem assinaladas pela Santíssima Trindade, pela participação na vida das Pessoas Divinas e pela manifestação da sua glória. O cristão é chamado pelo Pai à filiação adotiva e ao seguimento de Jesus Cristo, que se concretiza na ação e na graça do Espírito Santo na sua vida. Os padres conciliares reforçam a relação intrínseca entre o chamado do ser humano à santidade e a Santíssima Trindade.

O chamado à santidade se exprime na exigência estrutural de vida na graça. Como a santidade cristã não se restringe a gestos e ações rituais, sua característica particularmente notável é a realização do crescimento, pelo próprio exercício fervoroso da vida da graça. É uma santidade de amor. "É, pois, claro a todos que os cristãos de qualquer estado ou ordem são chamados à plenitude da vida cristã e à perfeição da caridade"773. Portanto, a perfeição cristã é um dom dado por Deus, mas também comporta em si uma decisão da vontade humana, que se decide por Cristo, excluindo de si todo o obstáculo à vida nova e à caridade ${ }^{774}$.

A santidade transborda da perspectiva individual para a eclesial, e desta para a sociedade terrena, na qual os chamados à santidade, pela sua vida e modo de agir, promovem um modo de vida mais humano. Se a caridade fraterna for

\footnotetext{
${ }^{771}$ VITALI, D., Lumen gentium, p. 105.

${ }^{772}$ CONCÍLIO VATICANO II, Lumen gentium 39.

${ }^{773}$ CONCÍLIO VATICANO II, Lumen gentium 40.

${ }^{774}$ LABOURDETTE, M., A santidade, vocação de todos os membros da Igreja, p. 1061-1063.
} 
assumida com seriedade e os ensinamentos de Jesus forem vividos intensamente, haverá uma mudança clara na sociedade, que se perceberá mais humana ${ }^{775}$.

No parágrafo quarenta e um, os padres conciliares expõem sobre a santidade nos diversos estados de vida. Porém, logo no início, reforçam que nos "vários gêneros e ocupações da vida, é sempre a mesma a santidade que é cultivada por aqueles que são conduzidos pelo Espírito de Deus"776. Como a Igreja é uma no seguimento do Senhor, cada um deve progredir, segundo os próprios dons e funções, sem desfalecimentos pelo caminho da fé viva, que estimula a esperança e que atua pela caridade ${ }^{777}$.

Finalizando o quinto capítulo, a Lumen gentium assinala a fundamentação teológica dos meios para se atingir a santidade, destacando a caridade, o martírio e os conselhos evangélicos. A Constituição dá uma importância a este último meio, pois o cita duas vezes, não para reforçar a santidade dos religiosos, mas como meio de perfeição para todos, de acordo com os conselhos que o próprio Cristo deu aos seus discípulos ${ }^{778}$.

Destaca-se, nesse parágrafo, que “o primeiro e mais necessário dom é a caridade, com que amamos a Deus sobre todas as coisas e ao próximo por amor d'Ele". Os padres conciliares reforçam que todo discípulo de Cristo se exercita neste dom maior, pois foi o próprio Senhor que o recomendou como mandamento maior. Ademais, é muito significativo que o Concílio, mesmo sendo dogmático e teológico, aponte sete meios práticos para o crescimento do discípulo na caridade: a palavra de Deus; cumprir a vontade de Deus; participar nos sacramentos, sobretudo na Eucaristia e nos ritos sagrados; dar-se à oração; à abnegação de si mesmo; ao serviço efetivo de seus irmãos; e a toda a espécie de virtude ${ }^{779}$.

Outro meio de santificação destacado pelos padres conciliares é o martírio, expressão de caridade e forma de o discípulo se tornar mais semelhante ao Mestre. O ponto de partida da revelação do amor do Pai por nós foi a entrega única e irrepetível do Filho na cruz. Aí está o fundamento cristológico de toda a santidade da Igreja, que permite à pessoa viver o amor de forma superior, doando a vida a Deus e aos irmãos. Por mais que os padres conciliares tenham afirmado que este

\footnotetext{
${ }_{775}$ MAZZOLINI, S., Vocazione universale alla santità nella Chiesa, p. 364-365.

${ }^{776}$ CONCÍLIO VATICANO II, Lumen gentium 41.

${ }^{777}$ LABOURDETTE, M., A santidade, vocação de todos os membros da Igreja, p. 1064-1065.

${ }^{778}$ IPARRAGUIRRE, I., Natureza da santidade cristã e meios para consegui-la, p. 1081-1082.

${ }^{779}$ IPARRAGUIRRE, I., Natureza da santidade cristã e meios para consegui-la, p. 1077-1078; CONCÍLIO VATICANO II, Lumen gentium 42.
} 
meio é concedido a poucos, S. Mazzolini afirma que, no passado, nas origens do cristianismo, muitos mártires deram o testemunho deste amor supremo ${ }^{780}$.

Irineu afirma na Epideixis que "o homem é um ser vivente, composto de alma e corpo; (...) existe uma santidade do corpo, que é a continência de todas as coisas descaradas e de toda ação iníqua, e uma santidade da alma, que conserva

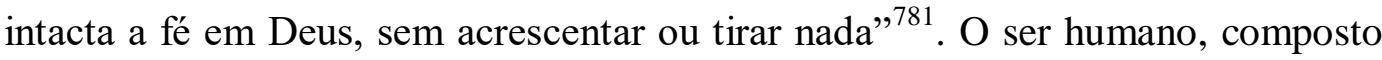
de corpo e alma em sua natureza racional, é completado pelo Espírito com a graça de Deus; esta plenifica a natureza racional.

A santidade de corpo e alma, segundo A. Orbe, é a perfeição para o ser humano que mantém a integridade da fé e das boas obras. Por isso, no parágrafo primeiro da Epideixis, Irineu reforça a importância de trilhar o caminho da piedade, pois é este que conduz à vida eterna. A santidade não é perdida somente quando o corpo é contaminado, mas também quando o pecado chega à alma, ou seja, à fé vivida e acreditada na Igreja ${ }^{782}$.

A oposição aos gnósticos é nítida na forma que Irineu define santidade, pois ele afirma que "verdadeiramente condenam-se a si mesmos quantos se separam da Igreja para aderir a tais falsidades" ${ }^{, 783}$. Essa é uma crítica ao ponto de vista dos gnósticos, visto que estes ignoram as preocupações com o corpo, pois, como pneumáticos, já estão salvos, isto é, têm o seu lugar certo no Pleroma. Desta forma, o bispo de Lião mostra que eles se afastam não somente da doutrina, mas também da vida verdadeira, que só têm os que se deixam envolver pela Verdade revelada em Cristo e, assim, enchem-se da graça do Espírito.

$\mathrm{Na}$ mesma perspectiva da Lumen gentium, a santidade é uma convocação para todos que aderem ao chamado de Deus na Igreja, que se decidem por viverem o seguimento de Jesus de forma clara. Com efeito, Irineu afirma que "assim devem comportar-se os crentes, pelo fato de que neles habita permanentemente o Espírito Santo, doado pelo Senhor no batismo e custodiado por aquele que [o] recebe, se é que vive na verdade e na santidade, na justiça e na paciência" ${ }^{784}$. Independentemente de meios específicos de santidade, a regula

\footnotetext{
${ }^{780}$ MAZZOLINI, S., Vocazione universale alla santità nella Chiesa, p. 374.

${ }^{781}$ IRINEU de Lião, Epideixis 2.

${ }^{782}$ ORBE, A., Antropología de San Ireneo, p. 309-310.

${ }^{783}$ IRINEU de Lião, Adversus haereses I, 16, 3.

${ }^{784}$ IRINEU de Lião, Epideixis 42
} 
fidei ${ }^{785}$, para Irineu, é o grande caminho de santidade. Foi por meio da fidelidade a ela que os cristãos ganharam o prêmio da vida incorruptível e da glória eterna reservada aos justos, aos santos e aos que guardaram os mandamentos e perseveraram no seu amor - alguns desde o início, outros depois de sua conversão $^{786}$.

Guardar os mandamentos e perseverar no amor é o grande caminho de santidade em Irineu de Lião, segundo J. Fantino. Dessa forma, "como a farinha seca não pode, sem água, tornar-se uma só massa nem um só pão, também nós não nos poderíamos tornar um só em Cristo, sem a água que vem do céu" ${ }^{\text {"787 }}$. É esta água que capacita cada pessoa a se tornar um ramo viçoso e frutuoso na videira do Senhor. Ela vem pelo Batismo, que une o ser humano a Cristo, o qual foi solidário para conosco na sua obra de recapitulação, livrando o ser humano do velho Adão.

Ainda pelo Espírito, que é a chuva generosa enviada do alto, o corpo humano recebeu a água pelo banho do batismo e a alma a recebeu pelo Espírito. Ou seja, a graça de Deus se encontra com a liberdade humana. A santidade só é possível pela decisão do homem de voltar-se para Deus e acolher o seu Espírito, que lhe dá vida nova. Portanto, os dois são necessários, porque ambos levam à vida de Deus ${ }^{788}$.

$\mathrm{Na}$ mesma linha do parágrafo quarenta e um da Lumen gentium, quando trata da santidade específica, conforme o estado de vida, Irineu reforça a importância da santidade dos bispos "junto dos que na Igreja possuem a sucessão dos apóstolos, a integridade inatacável da conduta e a pureza incorruptível da palavra"789.

Como afirma D. Singles, garantir a transmissão da fé é um exercício de caridade que cabe aos bispos. E uma leitura coerente e verdadeira das Escrituras não surge somente pelo fato de ser bispo, mas está ligada diretamente à integridade de vida do pregador. Como a tradição recebida e transmitida vem de fontes seguras, os apóstolos, aquele que assume a sucessão apostólica deve garantir a integridade de vida para honrar a santidade do que transmitiu. Tanto

\footnotetext{
${ }^{785}$ Como dito acima, p. 118-121.

${ }^{786}$ IRINEU de Lião, Adversus haereses I, 10, 1.

${ }^{787}$ IRINEU de Lião, Adversus haereses III, 17, 2.

${ }^{788}$ SINGLES, D., A glória de Deus é o homem vivo, p. 153-161; FANTINO, J., La théologie d'Irénée, p. 9-12.

${ }^{789}$ IRINEU de Lião, Adversus haereses IV, 26, 5.
} 
que, quando os gnósticos criticam muitos bispos pela pouca eloquência na pregação, Irineu os defende a partir da graça de Deus, que os escolheu para tal ministério, e da ilibada conduta dos bispos da Igreja ${ }^{790}$.

A santidade da Igreja, para Irineu, se firma no Espírito: “onde está a Igreja, aí está o Espírito de Deus, e onde está o Espírito de Deus ali está a Igreja e toda a graça. E o Espírito é verdade"791. Para Irineu, a Igreja é o Espírito de Cristo atuando no mundo e no coração dos homens. É o Espírito que determina as fronteiras da Igreja. Não que ela seja desencarnada, mas é tão encarnada na realidade humana, que, como Povo de Deus, reúne em si os novos filhos que Deus conquistou pela graça.

A Igreja é a assembleia de Deus ${ }^{792}$ que reúne os que se deixam nutrir pela graça do Senhor, pela Palavra, pela Eucaristia, na qual o Senhor entra em comunhão com a carne do ser humano na sua própria carne, conduzindo-o à incorruptibilidade ${ }^{793}$.

O martírio é abordado por Irineu numa perspectiva mais ampla e fundante que a Lumen gentium. Para o bispo de Lião, no martírio não ocorre a morte de uma pessoa, mas sim uma teofania do conteúdo profundo do batismo cristão. Para D. Singles, a comunhão dos santos é a comunhão dos que trazem a marca, o selo de pertencimento a Cristo, como sigilo da vocação assumida no Batismo: ser imagem e semelhança de Deus ${ }^{794}$. "Tendo recebido pelo Espírito a imagem e a inscrição do Pai e do Filho, façamos frutificar os dons que nos foram confiados e os restituamos multiplicados ao Senhor" ${ }^{\text {,795. }}$.

Irineu também aproxima o batismo da criação ${ }^{796}$, mostrando que a regeneração batismal, que torna os homens filhos de Deus no Filho Jesus, é a grande obra da recapitulação que o Cristo realizou. Se o ser humano foi criado à imagem e semelhança de Deus, o Cristo recapitula nele esta imagem, na sua entrega total. Ao ser batizado na morte de Cristo para receber a vida, o Espírito sela esse novo nascimento como uma graça fundante.

\footnotetext{
${ }^{790}$ SINGLES, D., A glória de Deus é o homem vivo, p. 161-163.

${ }^{791}$ IRINEU de Lião, Adversus haereses III, 24, 1.

${ }^{792}$ IRINEU de Lião, Adversus haereses III, 6, 1.

793 FANTINO, J., La théologie d'Irénée, p. 60-61; SINGLES, D., A glória de Deus é o homem vivo, p. 163-167.

794 SINGLES, D., A glória de Deus é o homem vivo, p. 157-158.

795 IRINEU de Lião, Adversus haereses III, 17, 3.

796 SESBOÜÉ, B., Tout récapituler dans le Christ, p. 66-70
} 
Sendo assim, afirma Irineu que a carne é fraca e o espírito está pronto, ou seja, é capaz de suprir a fraqueza da carne. "Portanto, se alguém misturar a prontidão do Espírito à fraqueza da carne, a fraqueza da carne será absorvida pela força do Espírito e quem era carnal será doravante espiritual, graças à comunhão do Espírito". Consequentemente, afirma o bispo de Lião: “assim os mártires testemunham e desprezam a morte não segundo a fraqueza da carne, e sim conforme a prontidão do Espírito"797.

A vitória do mártir não está na fraqueza da carne, mas sim na confiança do Senhor, e disso a Igreja inteira se beneficia. Segundo D. Singles, é no perfeito conhecimento da causa que o mártir expressa sua convicção de que a justiça de Deus se manifestará não somente na plenitude da imagem em cada um dos membros de Cristo, mas também na Igreja inteira ${ }^{798}$.

A plenitude de vida recebida no batismo se manifesta no fim, quando todos, conformados à cabeça, formarão a Igreja na plenitude. Mesmo mutilada pelas heresias e pelo martírio dos seus fiéis, a Igreja cresce e resgata os membros de Cristo, conduzindo-os à pátria definitiva, até resgatar todos os membros de Cristo $^{799}$.

\subsection{5.}

A índole escatológica da Igreja

O sétimo capítulo da Constituição Dogmática sobre a Igreja - Índole escatológica da Igreja peregrina e sua união com a Igreja celeste - teve seu início numa proposta apresentada pelo papa João XXIII, em 1961, à Congregação dos Santos, intitulada De consummatione sanctitais in gloria sanctorum.

O papa Paulo VI encaminhou o esquema à Comissão Teológica do Concílio, que o inseriu no esquema sobre a Igreja. $\mathrm{O}$ documento encontrou grande acolhida entre os padres conciliares, recebendo várias indicações. Por fim, foi tão bem integrado ao conjunto da Constituição Dogmática, que apresentou duas realidades complementares da Igreja: no capítulo segundo, reflete sobre o Povo de Deus em

\footnotetext{
${ }^{797}$ IRINEU de Lião, Adversus haereses V, 9, 2.

${ }^{798}$ SINGLES, D., A glória de Deus é o homem vivo, p. 159-160.

799 ORBE, A., Ecclesia, sal terrae según san Ireneo, p. 233-240; IRINEU de Lião, Adversus haereses III, 18, 5 .
} 
seu caminho para o Reino e o capítulo sétimo mostra o mesmo Povo de Deus em sua relação com as coisas últimas, a comunhão dos santos ${ }^{800}$.

O capítulo se divide em duas partes: os dois primeiros parágrafos (n.48-49) apresentam a meta escatológica da Igreja; nos dois últimos, reflete sobre as consequências da orientação escatológica na prática da veneração dos santos. Compõe-se, assim, o caráter escatológico da vocação cristã: a Igreja peregrina na fé e na esperança está unida no amor à Igreja do céu ${ }^{801}$.

A Igreja, inicia a Lumen gentium, "à qual todos somos chamados e na qual por graça de Deus alcançamos a santidade, só na glória celeste alcançará a sua realização acabada, quando vier o tempo da restauração de todas as coisas" ${ }^{\text {"02 }}$. Consequentemente, todos os homens e mulheres, a criação completa encontrará em Cristo sua restauração perfeita.

Enquanto o novo céu e a nova terra não chegam, a Igreja peregrina, na ordem temporal, vive entre as realidades passageiras sua santidade e aguarda a manifestação dos filhos de Deus. Nesta expectativa, o parágrafo quarenta e nove afirma que, enquanto o Senhor não vem para conduzir todos ao seu reino definitivo, "de modo nenhum se interrompe a união dos que ainda caminham sobre a terra com os irmãos que adormeceram na paz de Cristo, mas antes, segundo a constante fé da Igreja, é reforçada pela comunicação dos bens espirituais" $" 803$.

Desde o princípio do cristianismo, afirmam os dois últimos parágrafos desse capítulo, a Igreja peregrina, Corpo Místico de Cristo, conservou devoção aos seus falecidos, venerando-os pelo seu seguimento de Cristo e suplicando sua intercessão. Ademais, é na vida de tantos que se uniram mais perfeitamente a Cristo, mesmo participando da natureza humana, que Deus revela aos homens de maneira viva sua presença e sua face. "Pois, assim como a comunhão cristã entre os peregrinos nos aproxima mais de Cristo, assim a comunhão com os santos nos une a Cristo, de quem procedem, como de fonte e cabeça, toda a graça e a própria vida do Povo de Deus"

\footnotetext{
${ }^{800}$ VITALI, D., Lumen gentium, p. 125-126; CANOBBIO, G., Indole escatológica della Chiesa pellegrinante e sua unione com la Chiesa celeste, p. 397-398.

${ }^{801}$ LOPES, G., Lumen gentium, p. 137.

${ }^{802}$ CONCÍLIO VATICANO II, Lumen gentium 48.

${ }^{803}$ CONCÍLIO VATICANO II, Lumen gentium 49.

${ }^{804}$ CONCÍLIO VATICANO II, Lumen gentium 50.
} 
A índole escatológica da Igreja, em Irineu de Lião, passa pela perspectiva milenarista ${ }^{805}$ que os Padres da Igreja dos primeiros séculos cultivaram. Ademais, o bispo de Lião compreende na saída do Povo de Deus do Egito, conduzido por Moisés, a figura e o tipo do êxodo da Igreja. Esta, recapitulada pela encarnação do Verbo de Deus, no fim, sairá da terra para receber sua herança definitiva no Cristo, o Filho de Deus ${ }^{806}$. Então, não haverá mais uma Aliança firmada entre homens, que resgata os filhos de Deus; mas o próprio Deus, que armou sua tenda neste mundo, com a encarnação do seu Filho, agregará na Igreja os que são salvos. E ele mesmo, no final dos tempos, reunirá a todos no Reino de seu Pai ${ }^{807}$.

A Igreja, tanto a peregrina neste mundo, como a expectante no céu, agrega a si os justos que seguiram o Verbo de Deus na Palavra e na vida, e os vencedores que suportaram as tribulações e serão coroados com a incorruptibilidade ${ }^{808}$. De fato, como Povo de Deus a caminho, a Igreja constrói o grande edifício, que é o Corpo do Senhor. E faz isso quer pela pregação incessante, pelo ensino das verdades da fé e pela vivência e seguimento do Cristo junto a todos os irmãos; quer pelo Batismo, que agrega novos filhos para uma vida nova, pelo Espírito, que sela os que pertencem ao Senhor e pelo envio de uma multidão de mártires de todo tempo e lugar ${ }^{809}$.

\subsection{6.}

\section{A bem-aventurada Virgem Maria no mistério de Cristo e da Igreja}

O capítulo oitavo da Lumen gentium, segundo G. Baraúna, intitulado A Bem-aventurada Virgem Maria, Mãe de Deus, no mistério de Cristo e da Igreja, não constava no primeiro esquema De Ecclesia, mas sim no primeiro período do Concílio Vaticano II. Tratava-se de um esquema à parte, intitulado De Beata Maria Virgine, Matre Dei et Matre hominum.

O esquema foi distribuído aos padres conciliares, porém, antes de ser discutido publicamente, houve algumas intervenções notáveis que sugeriram a inserção do texto marial no esquema relativo à Igreja, o que já havia acontecido nas reuniões preparatórias.

\footnotetext{
${ }^{805}$ IRINEU de Lião, Adversus haereses V, 33, 4-36, 3; como dito acima, p. 196.

${ }^{806}$ IRINEU de Lião, Adversus haereses IV, 30, 4.

${ }^{807}$ SINGLES, D., A glória de Deus é o homem vivo, p. 193; IRINEU de Lião, Epideixis 94.

${ }^{808}$ IRINEU de Lião, Adversus haereses V, 29, 1.

${ }^{809}$ IRINEU de Lião, Adversus haereses IV, 33, 9.
} 
De acordo com D. Vitali, embora cerca de seiscentos bispos terem enviado à Comissão Preparatória do Concílio a proposta de um documento específico sobre Nossa Senhora, no primeiro esquema De Ecclesia não era possível encaixar o esquema De Beata. Ainda assim, pelas novas discussões realizadas entre o primeiro e o segundo períodos, o esquema De Ecclesia adentrou na perspectiva do mysteron, o que abriu espaço para o agigantamento das manifestações favoráveis à inserção do esquema De Beata no esquema De Ecclesia.

Apesar disso, a campanha panfletária contrária a essa proposta acusava os padres conciliares e peritos dizendo que: 1) queriam alterar a doutrina sobre a Virgem Maria, para a igualar aos seres humanos; 2) a teologia sobre Maria como tipologia da Igreja era uma doutrina nova, e não segundo a tradição; 3) quanto mais se diminuem os privilégios à Mãe de Deus, mais se diminui a devoção a ela, a ponto de não mais a considerarem verdadeiramente Mãe de Deus e Medianeira de toda a Igreja, a não ser nos escritos.

A divisão dos padres conciliares a respeito da inserção do esquema sobre a Virgem Maria no esquema sobre a Igreja ficou evidente na votação, pois foi vencida por somente quarenta votos de diferença. Todavia, o ganho para a reflexão sobre a Igreja foi gigantesco, visto que o ponto de convergência e a perspectiva fundamental do capítulo oitavo da Lumen gentium é a Virgem Maria, como objeto privilegiado da complacência de Deus, obra-prima da redenção que o Pai operou pelo Filho no Espírito Santo ${ }^{810}$.

Numa palestra feita por Karl Rahner, às vesperas da votação sobre a inserção do esquema De Beata no esquema De Ecclesia, na Domus Mariae, para bispos brasileiros e latino-americanos lá hospedados, segundo J. Libânio, que estava presente, o perito conciliar faz um resumo em dois tópicos sobre a importância de ser um único documento.

A inserção de Maria no documento sobre a Igreja, num primeiro argumento de K. Rahner, não pretendia desmerecer a dignidade e proeminência da Mãe de Deus, nem no plano salvífico nem na sua presença na Igreja. Pelo contrário, objetivava reforçar teologicamente este dois pontos. Numa segunda argumentação, o perito conciliar afirmava que Maria só pode ser entendida na sua

${ }^{810}$ BARAÚNA, G., A Santíssima Virgem a serviço da economia da salvação, p. 1157-1159; VITALI, D., Lumen gentium, p. 135-137; CANOBBIO, G., La Beata Vergine Maria Madre di Dio nel mistero di Cristo e della Chiesa, p. 423-434. 
relação com o mistério de Cristo, pois, como discípula fiel de Jesus, está presente à Igreja nos seus inícios. Conclui-se, então, a compreensão conciliar de que ela é typus Ecclesiae, figura da Igreja, como afirma Santo Ambrósio de Milão ${ }^{811}$.

No título do oitavo capítulo, A Bem-aventurada Virgem Maria, Mãe de Deus, no mistério de Cristo e da Igreja, o mysterium vem no singular porque, como explica o segundo esquema apresentado, conforme G. Canobbio, ao se tratar do mistério de Cristo, Verbo encarnado, o que se refere a Ele como fonte de todo mistério se refere à beata Virgem Maria; e, ao se falar de Maria, remete-se a Cristo como fonte.

Ademais, o mesmo mistério continua na Igreja, por meio da qual seus efeitos são aplicados. Sendo assim, a referência é única, o Cristo mistério de Deus. Maria é o coroamento da Constituição Conciliar sobre a Igreja, pois ela, como Mãe de Deus e Mãe do Povo de Deus, é o tipo exemplar da Igreja.

Por conseguinte, os padres conciliares aprovaram o oitavo capítulo com a seguinte distribuição: um proêmio, no qual se conectam as doutrinas sobre a Mãe de Jesus e sobre a Igreja (n. 52-54); prosseguindo, mostra a figura de Maria presente na história da salvação atestada pelas Escrituras Sagradas, e lidas à luz da tradição da Igreja (n. 55-59); então, detém-se na explicação da função de Maria na economia da salvação (n. 60-65); posteriormente, apresenta algumas indicações relativas ao culto mariano e à sensibilidade ecumênica com a qual se deve falar de Maria (n. 66-67); finaliza apresentando Maria, a Mãe de Jesus, como sinal do Povo de Deus, e exortando à pregação, a fim de realizar a unidade de todas as pessoas (n. 68-69).

$\mathrm{Na}$ segunda parte, do capítulo oitavo da Lumen gentium, "a Sagrada Escritura do Antigo e Novo Testamento e a venerável tradição mostram de modo progressivamente mais claro e como que nos põem diante dos olhos o papel da Mãe do Salvador na economia da salvação" ${ }^{\prime 812}$.

À luz das profecias e dos relatos do Antigo Testamento, lidos na lógica do cumprimento no Novo Testamento, os padres conciliares apresentam Maria como a Filha de Sião e a Mãe do Redentor, mas tudo conduzido pela interpretação do relato da anunciação do anjo Gabriel a Maria (Lc 1,26-38), que a apresenta como escolhida por Deus, mas também como mulher de fé, obediente e serva do Senhor.

${ }^{811}$ LIBÂNIO, J., Concílio Vaticano II, p. 143-144.

${ }^{812}$ CONCÍLIO VATICANO II, Lumen gentium 55. 
Maria não é instrumento meramente passivo, mas sim cooperadora na salvação e libertação da humanidade. "Esta associação da Mãe com o Filho na obra da salvação, manifesta-se desde a conceição virginal de Cristo até à sua morte" ${ }^{\text {813 }}$, quando, com o discípulo, toda a Igreja é acolhida pela Mãe do Salvador. Ademais, Maria, no cenáculo, acompanha a Igreja, nos seus primeiros passos, a acolher o Espírito e abrir-se ao chamado de Deus. Finaliza-se esta parte com o resgate da mariologia tradicional, enfatizando a virgindade perpétua de Maria, a imaculada conceição e sua assunção aos céus.

No capítulo oitavo da Constituição Lumen gentium, a terceira parte é a mais inovadora, trata da relação entre Maria e a Igreja, segundo H. de Lubac, surgiu na teologia contemporânea ao padres conciliares, de uma forma tão inesperada quanto deslumbrante. Esta característica tão significativa do cristianismo estava no horizonte da teologia dos Padres da Igreja e abre caminhos na teologia contemporânea ${ }^{814}$. Segundo G. Philips, a perspectiva é inovadora, pois Maria não é na Igrea um protótipo de poder hierárquico, mas sim modelo de receptividade espiritual diante da graça divina ${ }^{815}$.

Além disso, nesta terceira parte, segundo D. Vitali, há uma insistência dos padres conciliares na compreensão de Maria como Medianeira, mas a Lumen gentium conduz a discussão para outro caminho, que resultará na afirmação: “O nosso Mediador é só um... mas a função maternal de Maria em relação aos homens de modo algum ofusca ou diminui esta única mediação de Cristo; manifesta antes a sua eficácia» ${ }^{\wedge 16}$. Ou seja, Maria se torna participante na mediação de Cristo, frustrando os desejos de vários prelados, que queriam uma proclamação dogmática sobre Maria Medianeira de todas as graças.

No entanto, terminada essa discussão, os padres conciliares apresentam, segundo G. Cannobio, Maria como tipo da Igreja, ou melhor, pelo dom e missão, "a maternidade divina, que a une a seu Filho Redentor e, pelas suas graças e funções, está também a Virgem intimamente ligada à Igreja: a Mãe de Deus é o tipo e a figura da Igreja, na ordem da fé, da caridade e da perfeita união com Cristo" ${ }^{\text {817. }}$

${ }^{813}$ CONCÍLIO VATICANO II, Lumen gentium 57.

${ }^{814}$ DE LUBAC, H., Paradosso e mistero della Chiesa, p. 58-61.

${ }^{815}$ PHILIPS, G., La chiesa e il suo mistero, p. 367.

${ }^{816}$ CONCÍLIO VATICANO II, Lumen gentium 60.

${ }^{817}$ CONCÍLIO VATICANO II, Lumen gentium 63. 
A relação entre Maria e a Igreja é construída no Concílio, segundo H. de Lubac, dando preferência ao tema do Povo de Deus, pois a imagem da filha de Sião é personificada na comunidade messiânica, o pequeno grupo que retorna do exílio para Jerusalém. Já no Novo Testamento, a Igreja, segundo o evangelista João, é quem gera o povo messiânico, expressão comunidade eclesial. Maria, no Concílio Vaticano II, consagrou por sua própria autoridade algo que provém da profundidade da consciência católica. Não está baseado nos estudos eruditos, nem na história do dogma, nem na piedade popular, nem nesses laços misteriosos, nem nos testemunhos da tradição; mas, de forma totalmente independente, esses testemunhos foram reorientados e, de certo modo, reinventados e revividos, embora muito diferentes uns dos outros. Paul Claudel afirma que a Santa Virgem Maria está tão estreitamente unida à Igreja, que não é mais possível distinguir uma da outra ${ }^{818}$.

A teologia de Irineu em torno do papel da Virgem Maria na economia da salvação do Pai, iniciada pelo Verbo que se encarnou, é ampla e se espalha por todos os seus escritos ${ }^{819}$.

A Constituição Lumen gentium faz uma referência direta à teologia irineana no oitavo capítulo, na segunda parte, quando trata da Virgem Santíssima na economia da salvação - as únicas duas referências diretas a um Padre da Igreja são a Irineu de Lião, nos parágrafos vinte e cinquenta e seis ${ }^{820}$ - "Como diz S. Irineu, 'obedecendo, ela tornou-se causa de salvação, para si e para todo o gênero humano' (Adversus haereses III, 22, 4)" ${ }^{\prime 821} \mathrm{e}$ "Eis porque não poucos padres afirmam com ele, nas suas pregações, que 'o nó da desobediência de Eva foi desatado pela obediência de Maria; e aquilo que a virgem Eva atou, com a sua incredulidade, desatou-o a Virgem Maria, com a sua fé' (Adversus haereses III, $22,4)^{», 822}$. Ambas as citações se referem à compreensão mais importante de Irineu: que a Virgem participa da recapitulação que Cristo veio realizar.

Primeiramente, pela encarnação do Verbo de Deus a partir do sim da Virgem, Irineu refuta as teses valentinianas que defendiam a encarnação somente como aparência, e não como fato concreto. Nos dois primeiros séculos do

\footnotetext{
${ }^{818}$ DE LUBAC, H., Paradosso e mistero della Chiesa, p. 65-70.

${ }^{819}$ Como dito acima, p. 132-138.

${ }^{820}$ GIANOTTI, D., I Padri della Chiesa al Concílio Vaticano II, p. 313-314.

${ }^{821}$ CONCÍLIO VATICANO II, Lumen gentium 56.

${ }^{822}$ CONCÍLIO VATICANO II, Lumen gentium 56.
} 
cristianismo, a luta contra as controvérsias docetistas foram muito significativas, pois não somente diminuíam a obra realizada por Cristo, como rompiam com a economia da salvação do Pai, visto que, se o Filho não assumiu nossa natureza, esta não foi salva.

Em seguida, Irineu refutará os gnósticos ${ }^{823}$ afirmando que o nascimento na carne do Filho de Deus, vindo de Maria, não só ocorreu, como Deus fez dela partícipe da obra salvadora do Cristo ${ }^{824}$. O bispo de Lião alega que "o Espírito Santo sobreveio em Maria e que o poder do Altíssimo a cobriu com sua sombra e

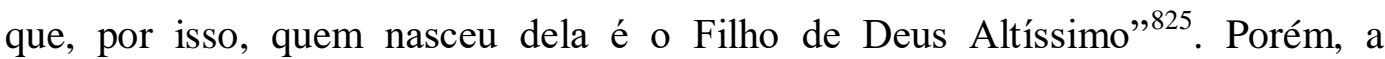
encarnação do Filho de Deus foi igual a um "novo nascimento, a fim de que, tendo nós herdado a morte pelo nascimento anterior, por este, herdássemos a vida $^{\sharp 26}$, visto que Deus não refaz a criação, mas adentra nela com o seu Filho para a resgatar por dentro.

Para tanto, Irineu aprofunda que seria impossível pensar o plano de salvação de Deus, se não fosse igualando seu Filho à nossa realidade. E Maria, na sua obediência aos projetos de Deus, acolhe este plano de salvação e permite que ele aconteça na sua vida. Deus, ao se utilizar da virgindade e da humanidade ${ }^{827}$ de Maria, torna-a partícipe da recapitulação que Jesus Cristo realizou ${ }^{828}$.

No paralelismo entre Eva e Maria, segundo E. Peretto, Irineu apresenta o sinal da Virgem ${ }^{829}$, ou melhor, a obediência de Maria, que vence a desobediência de Eva, ambas virgens, mas com atitudes totalmente diversas, pois Eva opta por ouvir a serpente e abandonar a proposta que o Criador lhe fizera; já Maria ouve a proposta de Deus pelo anjo e a acolhe plenamente. Por conseguinte, em Maria, Deus recapitula toda a criação e executa em seu Filho, o novo Adão, a economia da salvação.

A fé e a obediência de Maria ao Criador fazem um caminho inverso. Por isso, reforça a Lumen gentium que Maria desata os nós que Eva atou com sua incredulidade; de Maria Virgem a Maria esposa de José, e da esposa de José a toda a família humana, e de José a Adão, e isso com eficácia universal. Deus

\footnotetext{
${ }^{823}$ IRINEU de Lião, Adversus haereses I, 7, 2.

${ }^{824}$ SINGLES, D., A glória de Deus é o homem vivo, p. 66.

${ }^{825}$ IRINEU de Lião, Adversus haereses V, 1, 3.

${ }^{826}$ IRINEU de Lião, Adversus haereses V, 1, 3.

${ }^{827}$ IRINEU de Lião, Adversus haereses III, 22, 2.

${ }^{828}$ IRINEU de Lião, Adversus haereses III, 21, 4.

${ }^{829}$ IRINEU de Lião, Epideixis 33; IRINEU de Lião, Adversus haereses III, 22, 4; DE LUBAC, H., Paradosso e mistero della Chiesa, p. 60-61.
} 
restaura o plano primitivo de salvação da humanidade. A Virgem não é uma criatura celeste, mas sim terreste, que veio precisamente para Eva, uma criatura terrestre que a precedeu no tempo; Maria é a Virgem que veio na plenitude dos tempos pela primeira virgem, mulher de $\operatorname{Adão}^{830}$.

Ao tratar da relação entre Maria e a Igreja, Irineu afirma que "Maria cantava profeticamente, em nome da Igreja: 'A minha alma glorifica o Senhor e meu espírito exulta em Deus, meu Salvador. Socorreu Israel, conforme prometera a nossos pais, em favor de Abraão e de sua descendência, para sempre" "831. Maria canta em nome do novo Povo de Deus. Ela, como Mãe do Messias, proclama as maravilhas de Deus na sua vida e naqueles que se colocam como seguidores do seu Filho.

O que quer dizer Irineu, ao proclamar que Maria é a fonte da regeneração? Ele afirma que, em Maria, pela encarnação do Filho, Deus prefigurou uma nova geração, não herdada da morte, como fora por Eva, mas herdada da vida que nos vem do Cristo, novo Adão. Essa vida se perpetua por meio da Eucaristia, Corpo e Sangue de Cristo, fonte de Vida Eterna. Maria canta em nome da Igreja e conclama, segundo Irineu, toda a Igreja a proclamar a fonte de vida que o Senhor manifestou a todos, pela obra da salvação inaugurada no Cristo Jesus ${ }^{832}$.

\footnotetext{
${ }^{830}$ PERETTO, E., Ireneo di Lione, p. 219-221.

${ }^{831}$ IRINEU de Lião, Adversus haereses III, 10, 2.

${ }^{832}$ OSBORN, E., Irenaeus of Lyons, p. 117-118.
} 


\section{5. \\ Considerações finais}

A comparação da eclesiologia de Irineu de Lião com a Lumen gentium surge no contexto do movimento de retorno às fontes cristãs nos séculos XIX e XX. O Concílio Vaticano II foi traspassado pelo ressourcement no seu processo de aggiornamento da Igreja no mundo moderno. A eclesiologia de Irineu de Lião, com seus antecedentes bíblicos e patrísticos, abre um arcabouço teológico próprio das comunidades cristãs dos dois primeiros séculos. $\mathrm{O}$ cristianismo passa por um processo de emancipação do judaísmo, para constituir um movimento autônomo. Nesse contexto, Irineu aparece como um dos primeiros pensadores cristãos a fundamentar as características destes pequenos grupos que se espalhavam por todo Império.

Na sua missão de denunciar o que não era próprio da tradição apostólica e de refutar as doutrinas erradas que adentravam as comunidades nesse processo emancipatório cristão, o bispo de Lião costruiu um fértil pensamento teológico do qual, nesta pesquisa, coletamos a sua compreensão sobre a Igreja.

Portanto, esta pesquisa, ao comparar o pensamento eclesiológico de Irineu com o desenvolvido na Lumen gentium, busca as referências que estão no texto conciliar e recupera as múltiplas concepções de Igreja que foram possíveis elencar por meio de uma análise comparativa, para assim perceber como o modelo eclesiológico do início do cristianismo possiblita uma compreensão maior e mais profunda de um texto contemporâneo.

A pesquisa foi organizada em cinco capítulos. No primeiro capítulo, foi apresentada a introdução da Tese. No segundo capítulo, foram apresentadas as fontes do pensamento irineano, em seus antecedentes patrísticos e bíblicos. Iniciando pela compreensão de ekklesía no Antigo Testamento que partia de dois termos hebraicos, 'eda que representa a totalidade da comunidade judaica, e qahal que é a comunidade convocada. Depois, no Novo Testamento há dois aspectos fundamentais da compreensão de ekklesía: como assembleia de Deus e como um vínculo comunitário existente entre os crentes em Cristo. 
Nas fontes patrísticas a perspectiva de assembleia e agregação assumem várias interpretações. Clemente afirma que a Igreja se traduz na vida de cada fiel, e todos numa comunhão de sentimentos e de pensamentos. É neste amor que a Igreja de Cristo encontra a paz, a unidade, a fraternidade e se reúne como novo Povo de Deus. Na leitura do epistolário de Inácio de Antioquia se compreende a Igreja em duas dimensões fundamentais: a sua unidade como comunidade liderada pelos seus dirigentes e a eucaristia como realidade constitutiva desta comunidade. Em Hermas, a agregação da Igreja é o que possibilita a salvação. A comunidade reúne as diversas categorias de fiéis para formar a assembleia do Senhor, na qual não há distinção entre as pessoas, pois todos em Cristo formam o grande edifício de fé. Justino mostra que a comunidade se reúne nas orações, nas celebrações e no socorro dos mais necessitados. No entanto, pelo batismo é que se compreende a profundidade da comunidade, que pelo banho da regeneração e pela eucaristia agrega os irmãos em Jesus Cristo. Em Melitão de Sardes a Igreja é receptáculo da verdade que Deus revelou e o Corpo de Cristo que no mistério pascal celebra essa pertença ao Senhor. No epitáfio de Abércio a compreensão de agregação ganha contornos muito importantes pela antiguidade e também elementos que o autor apresenta. A comunidade é pastoreada pelo Cristo, "casto pastor" que enxerga a todos; ela tem em Roma a rainha de grande beleza, mas também nela se estabelece a representação universal de toda Igreja peregrina, rumo à Jerusalém celeste; ela reúne os marcados com o sigilo que lavaram suas vestes no sangue do cordeiro; ela é aquela que tem irmãos em todos os lugares, sempre prontos a partilharem a alegria, a fé e o alimento: pão, peixe e vinho. Em contraposição, a agregação a um grupo gnóstico nasce de uma experiência existencial e individual, pois a pessoa sente a necessidade de se libertar da prisão do mundo material, das suas adversidades, para retomar seu lugar no Pleroma.

Em relação às fontes bíblicas, Irineu é um dos primeiros Padres da Igreja a se servir de um vasto uso das Sagradas Escrituras, não somente por citações, mas também por causa da compreensão da continuidade da revelação reconhecida em ambos os testamentos. A sua hermenêutica dos textos escriturísticos parte da Tradição qual um princípio universal e fundante, sobre tudo porque precisa combater os marcionitas que ignoram o Deus que chamou Abraão e os gnósticos que utilizam da alegoria para descobrir nas Sagradas Escrituras os segredos escondidos. Por meio da tipologia, Irineu compreenderá que a Igreja foi revelada 
nas Sagradas Escrituras, não somente no Novo Testamento, mas também prefigurada nos relatos veterotestamentários.

No terceiro capítulo, reflete-se sobre a ortodoxia de Irineu presente na suas duas obras Adversus haereses e Epideixis. Primeiramente, descreve-se a gnose valentiniana como Irineu a apresenta: o dualismo entre o mundo espiritual e o mundo material; o surgimento do Pleroma; o desprezo à matéria, por ter se originado de uma entímese expulsa do Pleroma; a antropologia gnóstica tripartida - pneumáticos, hílicos e materiais; a soteriologia gnóstica que aguarda o retorno ao mundo espiritual; e suas diversas doutrinas. Na descrição irineana do sistema gnóstico valentiniano há uma processo de degradação das emanações, separandoas por importância na ordem que foram surgindo, porém, não é possível compreender o sistema gnóstico fora de um contexto eclesiológico claro e definido. Por isso, o termo Igreja, a hierarquia dos éons e a própria gnose como produto doutrinal de conhecimento designam, quer porque dependa do cristianismo, quer porque faz o cristianismo depender dela, os mais antigos conceitos ligados à eclesiologia desse grupo.

Em sequência, examinou-se o pensamento de Irineu sobre a Igreja. O bispo de Lião afirma que a Igreja é obra de Deus, que, no mistério insondável do seu amor de Pai pelo ser humano criado, envia o Filho, Jesus Cristo, para recapitular a criação, para resgatar o homem decaído e restituir-lhe a dignidade de filho por meio da adoção em Cristo. Sendo assim, a encarnação do Filho de Deus marca o início da Igreja que tem em Cristo seu grande modelo, enquanto ela é conduzida e guiada pelo Espírito de Deus que impulsionou os apóstolos na missão de levar a revelação de Cristo a todos. A Igreja é a grande assembleia reunida por Deus, em torno do mistério pascal do seu Filho e da graça do Espírito. Ela chegará à sua consumação quando todos os membros do Cristo estiverem agregados ao seu Corpo.

Para Irineu, como ambos os testamentos marcam uma única revelação, a Igreja está prefigurada-presente em alguns relatos do Antigo Testamento: jardimparaíso plantado por Deus no Éden; no relato de Noé; na descendência de Davi; na profecia de Oséias e Isaías; e no povo libertado do Egito que constrói no Senhor a sua habitação definitiva. Ora, a relação entre a promessa feita a Abraão para constituí-lo como um grande povo e a Igreja nascida da nova Aliança em Cristo é um dos elementos primordiais que distinguem a Igreja na obra de Irineu 
de Lião. A Igreja é, portanto, o edifício de Deus, constituído a partir dos inúmeros fiéis que acolheram a Boa Nova e a verdadeira gnose que é a doutrina dos apóstolos difundida na Igreja em todo tempo e por todo o mundo.

Ademais, Irineu compreende a Igreja dos que receberam de Cristo, através dos apóstolos a missão de conduzir e pastorear os fiéis. De fato pela sucessão apostólica os encarregados de tal ministério transmitem a tradição recebida de fonte segura, proclamam as Sagradas Escrituras e ensinam a regula fidei. A Tradição apostólica é indicada como um critério de autoridade para a comunidade cristã, ou seja, é aquilo que dava fundamento e autenticidade para o modo de vida dos cristãos. A regra de fé é um instrumento de discernimento entre as verdades de fé e os desvios ensinados pelos gnósticos, que a Igreja, constituída pelo Senhor como luz, através da pregação verdadeira e firme a utiliza para iluminar o caminho até a vida verdadeira em Jesus Cristo. Estas são três bases fundamentais da vida cristã, que a partir do banho da regeneração, que mergulha a pessoa no mistério trinitário, sustenta os fiéis na sua vida concreta, enquanto Cristo os alimenta com seu corpo e sangue, mistério de Deus comunicado pela Igreja aos que creem. Além disso, para Irineu a presença da Virgem no mistério e no ministério de Jesus Cristo foi essencial. Sendo assim, ela é o modelo de obediência à vontade do Senhor e de decisão pela vida plena em Deus, que nos vem pelo seguimento do seu Filho Jesus Cristo e pela abertura à graça do Espírito.

O quarto capítulo inicia mostrando o desenvolvimento do aggiornamento teológico que traspassará o Concílio Vaticano II, trazendo aos padres conciliares a consciência de uma necessária mudança na Igreja. Visto que o movimento teológico e o apelo pastoral convocavam a Igreja a se inserir na realidade humana com renovado ardor. O movimento de volta as fontes cristãs - patrísticas e medievais - trouxeram aos padres conciliares um novo vigor espiritual, pois o frescor da fé e da vivência dos primeiros cristãs invadiram as aulas conciliares. Entretanto, a abordagem neoescolástica das fontes cristã não possibilitou uma compreensão mais clara e profunda da teologia dos primeiros séculos. Obra que ocorrerá ulteriormente ao Concílio.

$\mathrm{Na}$ sequência, apresenta um histórico sobre o desenvolvimento da Constituição sobre a Igreja que é considerado o documento central do Concílio Vaticano II. De fato, a Lumen gentium colocou as questões sobre a Igreja no centro do Concílio Vaticano II, não somente porque favoreceu uma discussão 
ampla sobre a eclesiologia, mas também porque mostrou que, para fazer um aggiornamento, ou definir a presença da Igreja no mundo, sua ação pastoral e sua organização, é preciso refletir sobre seus fundamentos e identidade, além de ouvir a tradição e os Santos Padres. Como afirma o papa Paulo VI, é a Igreja olhando para si mesma e dizendo sobre si mesma.

Neste momento do quarto capítulo reflete-se sobre a Lumen gentium e a eclesiologia de Irineu de Lião, objetivo central desta pesquisa. Para tanto este momento foi dividido em seis partes, compreendendo seis capítulos da Lumen gentium: o mistério da Igreja, o Povo de Deus, o episcopado e sucessão apostólica, a vocação à santidade universal, a índole escatológica da Igreja e a bem-aventurada Virgem Maria no mistério de Cristo e da Igreja.

A Igreja entendida como mistério, na primeira parte, foi uma nova perspectiva apresentada pelos padres conciliares na Lumen gentium. Pois ao se voltarem à compreensão de mistério, percebem Deus que no seu desígnio eterno age em favor da humanidade. Por isso reconhecem que Cristo é a luz dos povos, e a Igreja é sinal dessa luz de Cristo para o mundo. De fato o mistério da Igreja tem em Cristo seu fundamento e sustenação. Sendo assim, os padres conciliares também reconhecem a Igreja como de sacramento de Cristo, pois como sacramento ela torna presente o Cristo nas suas ações e como instrumento ela comunica a graça do Cristo a cada um.

Ademais, os padres conciliares resgataram, ainda no primeiro capítulo da Lumen gentium, o mistério fundamental do cristianismo, que é a Trindade, e mostraram que só é possível compreender o mistério da Igreja à luz da economia da salvação: do Pai, do Filho e do Espírito Santo. Também relacionaram a Igreja com o Reino de Deus, afirmando que a Igreja constitui o germe e o princípio deste mesmo Reino na terra. Vivendo numa tensão escatológica, do já e ainda não. Irineu, remetendo à tradição dos patriarcas e profetas, afirma que o Reino de Cristo, que está presente a todos para os quais, desde o início, Deus quis que o Verbo estivesse presente. A Lumen gentium é finalizada com as imagens da Igreja presentes no Novo Testamento, retomando o modelo patrístico de reflexão eclesiológica. Além de um parágrafo específico sobre a imagem da Igreja, baseada na teologia paulina: Corpo Místico de Cristo. E um último parágrafo sobre a perspectiva teândrica da Igreja. 
Na comparação da eclesiologia irineana com a eclesiologia conciliar, nesta primeira parte, surgem alguns pontos interessantes de reflexão.

Primeiramente Irineu tem clara consciência de que a Igreja no mundo é sinal da luz de Cristo. A imagem da luz do Sol que brilha sobre todo o mundo, é a luz da pregação e da fé da Igreja em Cristo, que ilumina todos os povos e os une sob uma mesma fé. Esta é a catolicidade da Igreja, que anuncia a todos a verdade que recebeu do Pai, pelo Filho, e o faz por meio do Espírito. Portanto, a Igreja não é, ela própria, a luz dos povos, porque a luz dos povos é Jesus Cristo, em cuja face humana resplandece a imagem do Deus Vivo. Irineu resume isso afirmando que "Deus é a glória do homem e o homem é o receptáculo da obra, de toda a sabedoria e do poder de Deus" ${ }^{\text {833 }}$, ou ainda, "a glória de Deus é o homem que vive e a vida do homem consiste na visão de Deus" ${ }^{\text {} 834}$.

Não é um homem vivo na eternidade, mas sim vivente. Irineu mostra uma consciência clara da missão da Igreja de ser no mundo sinal do Cristo luz, para iluminar a todos com a verdade e com a graça que ela recebe do alto. De fato, como candelabro de sete velas, a Igreja porta o Messias a todos os lugares onde vai. E ele como portador dos sete dons do Espírito os comunica através da Igreja. É assim que a Igreja se reconhece como Reino de Cristo, pois pela Boa Nova anunciada e acolhida como sinal de conversão, estes, evangelizados e evaneglizadores tornam-se membros deste Reino.

Igreja é voltada para os homens, ela é com o ser humano, não é uma Igreja em si e para si mesma. Por isso ela é em vaso precioso, que se renova e renova o próprio vaso que a contém, nesta perspectiva Irineu a entende como sacramento. A Igreja não só comunica a graça de Deus, que recebeu pelo Espírito Santo, como também essa mesma graça age nela mesma, transformando-a. Por isso, como sacramento e instrumento este dom de Deus foi confiado à Igreja, como o sopro de vida inspirado na obra modelada, para que sejam vivificados todos os membros que o recebem.

$\mathrm{Na}$ perspectiva da Igreja mistério e sacramento, que surge em Irineu na perspectiva da Igreja como mãe que alimenta seus filhos nos seus seios para a vida e, assim, estes recebem a vida da fonte puríssima, que procede do Corpo de Cristo. O sinal sacramental é apresentado com toda a sua profundidade de sinais

${ }^{833}$ IRINEU de Lião, Adversus haereses III, 20, 2.

${ }^{834}$ IRINEU de Lião, Adversus haereses IV, 20, 7. 
visíveis e invisíveis. A Igreja é onde se manifesta a ação salvífica de Deus e, ao mesmo tempo, o instrumento por meio do qual Deus realiza a sua vontade salvífica. A diástase da Igreja e do Reino, na dinâmica do já e ainda não, na Lumen gentium, está presente na teologia irineana.

Entretanto ela sabe sua missão no mundo de ser sal, de resplandecer a luz do Cristo, de anunciar a Boa Nova, de reunir os filhos e filha dispersos, de agregar a si o que Deus lhe confiou na recapitulação que o Cristo realizou. Não é uma Igreja estática ou mística, pois Irineu combate os gnósticos que se apoaiam nessas perspectivas. Mas sim é uma Igreja: dinâmica, presente, clara, cheia do Espírito, que se renova, que se insere nas diversas realidades, anuncia. "Recordamos Irineu que fala da fé vivificante na qual somente a Igreja, mais fecunda que a antiga sinagoga, sustenta seus filhos" ${ }^{\text {,835. }}$.

$\mathrm{Na}$ segunda parte, a ideia da Igreja Povo de Deus surge no Concílio valorizando perspectiva pastoral em detrimento da jurídica. Retoma-se a perspectiva bíblica do povo resgatado, liberto e conduzido pelo Senhor. A Igreja Povo de Deus se destina a abranger todas as regiões, entrar na história dos homens, ao mesmo tempo que transcende os tempos e as fronteiras dos povos. Ademais também reflete sobre a teologia do sacerdócio comum dos fiéis, resgatado da teologia bíblica e patrística. O sacerdócio comum é o sacerdócio primordial e indispensável a toda consagração posterior, porque outra qualquer participação no sacerdócio de Cristo não é senão o desenvolvimento ulterior desta incorporação fundamental. Finaliza a segunda parte com a reflexão sobre o caráter missionário da Igreja, como uma dimensão eclesial constitutiva, que aprofunda ainda mais a natureza do povo de Deus.

Ao comparar esta parte da Lumem gentium com a eclesiologia irineana, a revolução que o concílio fez em assumir a Igreja como novo povo de Deus contendo em si a hierarquia, Irineu não só assumiu a Igreja povo de Deus como amplia a dimensão de sua teologia. Visto que, o grande projeto de salvação do Pai foi recapitular toda a criação na encarnação do seu Filho Jesus. Nisso Ele também agregou em si tudo e todos, conduzindo-os do deserto do sofrimento para onde foram mandados após banidos do Jardim do Éden, para o encontro integrante e integrador com seu Deus e Pai. Deste modo, o povo de Deus não é somente a

${ }^{835}$ DE LUBAC, H., Paradosso e mistero della Chiesa, p. 48. 
hierarquia ou um novo grupo, mas sim todos os que em Cristo receberam vida nova e se voltaram para ouvir e nutrir-se da fonte da vida. Não é uma salvação exclusivista, mas sim integradora. Tudo foi recapitulado e todos têm a possibilidade de se achegarem.

Além disso, a reagregação do ser humano, num novo povo de Deus, fora necessária para que todos os homens e mulheres pudessem descobrir a maravilha das suas vidas e reconhecer seu Senhor e Criador. Por isso a perspectiva missionária da Igreja é fundante de Irineu. Como bispo ela sabe sua missão de anunciar e denunciar, ensinar e confirmar na fé, para conservar os que estão neste povo, mas também sair ao encontro dos que ainda cavam cisternas seca ou estão nos lamaçais dos ensinamentos errado.

Irineu não utiliza a expressão sacerdócio comum dos fiéis para se referir aos batizados, visto que reserva os vocábulos sacerdócio e sacerdote para se referir aos descendentes de Aarão, no Antigo Testamento, ao múnus de Cristo e aos apóstolos. Porém, em Jesus Cristo sacerdote, profeta e rei, todos recebem a regeneração, e participam da economia da salvação, deixando de ser oliveira bravia, abandonada no deserto árido, para se tornar oliveira fértil. Da teologia irineana sobre o batismo se apreende uma compreensão da teologia do sacerdócio comum dos fiéis como membros do novo povo de Deus. O batismo confere aos cristãos a fé e, por meio dela, quem adentrar no tesouro sagrado da tradição apostólica, da regula fidei, das práticas e experiências cristãs, deixa de ser um homem velho, pois foi recapitulado em Cristo. O batismo marca, para o bispo de Lião, o ingresso neste novo povo de Deus, porque o batismo é o selo da vida eterna, o novo nascimento em Deus, de modo que já não somos mais filhos de homens mortais, mas do Deus eterno e indefectível.

$\mathrm{Na}$ terceira parte, a Lumen gentium apresenta uma nova visão teológica sobre o ministério ordenado na Igreja, que deve ser lida e compreendida a partir da Igreja novo povo de Deus, visto que o ministério ordenado, primeiramente é pensado como serviço na Igreja e para a Igreja povo sacerdotal e comunidade carismática. Além disso, todos os batizados são chamados ao serviço dos irmãos na caridade e reconhecidos como sujeitos participantes da missão eclesial, portadores de uma palavra necessária na proclamação da fé e na compreensão do Evangelho. 
O capítulo terceiro da Lumen gentium inicia retomando a doutrina do primado pontifício. Entretanto, os padres conciliares fundamentam a vocação hierárquica da Igreja sobre o mandato e a instituição dos doze apóstolos e nos bispos como sucessores diretos deles. Com isso, retomam a teologia patrística dos três primeiros séculos, que afirmava o episcopado não a serviço do papa, mas sim como mandato do próprio Senhor.

Uma das partes mais importantes do capítulo terceiro é a reflexão sobre a sacramentalidade do episcopado, estes pastores, escolhidos para apascentar o rebanho do Senhor, são ministros de Cristo e dispensadores dos mistérios de Deus, juntamente com o poder de santificar, confere também os poderes de ensinar e governar. A descoberta do caráter colegiado do episcopado representa um dos elementos de novidade na compreensão do Vaticano II, e tem todas as credenciais para ser considerado um progresso real da eclesiologia. Posto isto, ela apresenta o episcopado numa organização mais harmônica e comunional, assemelhando-se à sua original instituição, que foi o colégio apostólico, instituído por Cristo.

A Lumen gentium cita Irineu de Lião para confirmar a sucessão apostólica, porém na obra irineana ela não tem sinal de poder ou autoridade sobre algo ou alguém. Mas sim, brotou do próprio mandato de Cristo aos seus apóstolos e da graça do Espírito que em Pentecostes os impulsionou para levar a todos a Boa Nova. A autoridade que a Tradição apostólica apresentava, era sim uma autenticação de veracidade da vivência cristã, por isso os bispos deveriam ter uma vida ilibada, pois testemunhavam pelo anúncio e pela prática do que pregavam. Por conseguinte, a tradição está materializada nas Escrituras que a comunidade conserva com fidelidade, e também presente nos ensinamentos e pregações orais, que, em virtude de seguirem a regula fidei, são isentos de fraude e em plena conformidade. Apesar disso, o que de mais importante a tradição apostólica conserva é o dom da caridade, mais precioso que todo conhecimento, que toda profecia e superior a todos os outros carismas.

Ao refletir sobre a colegialidade na eclesiologia irineana, novamente o poder e a força não são partes fundantes. $\mathrm{O}$ episcopado não é monárquico, mas sim caritativo, testemunhal, exortativo. No relato da visita de Policarpo, bispo de Esmirna a Aniceto, bispo de Roma, como também na visita de Irineu, bispo da Gália, a Vitor, bispo de Roma, ambas para tratarem sobre a data da Páscoa, Irineu 
mostra mais do que um primado potifício do bispo de Roma, mas sim um primado na caridade. Ele é para toda Igreja o sinal das duas colunas da Igreja - Pedro e Paulo - que ali deram seu testemunho de vida, no anúncio e na entrega plena no martírio, por isso é uma igreja mais veneranda. Vitor, conforme Eusébio de Cesareia, pode não ter aceitado os questionamentos de Polícrates, bispo na Ásia, mas se dispôs a dialogar com Irineu, que num processo de pacificação agrega novamente os irmãos. Percebe-se ai, a colegialidade episcopal presente, não brotando da autoridade de uma pessoa, mas da rocha, que é o Cristo. Do seu coração, fendido como a rocha fendida por Moisés no deserto, correram doze fontes de água, que são a doutrina dos doze apóstolos, que transmitiram à Igreja.

$\mathrm{Na}$ quarta parte do capítulo, tratou-se do tema da santidade que, segundo a Lumen gentium, transborda da perspectiva individual para a eclesial, e desta para a sociedade terrena, na qual os chamados à santidade promovem um modo de vida mais humano. Se a caridade fraterna for assumida com seriedade e os ensinamentos de Jesus forem vividos intensamente, haverá uma mudança clara na sociedade, que se perceberá mais humana. $\mathrm{O}$ chamado à santidade, como afirma $\mathrm{o}$ capítulo quinto da Lumen gentium, é uma condição a que são convocados todos os membros do Povo de Deus pela força do batismo, e não somente os consagrados em razão da observância dos conselhos evangélicos.

Comparando essa parte com a antropologia irineana, a santidade de corpo e alma é a perfeição para o ser humano que mantém a integridade da fé e das boas obras. Por isso, Irineu reforça a importância de trilhar o caminho da piedade, pois é este que conduz à vida eterna. A santidade não é perdida somente quando o corpo é contaminado, mas também quando o pecado chega à alma, ou seja, à fé vivida e acreditada na Igreja. Desta forma a regula fidei, para Irineu, é o grande caminho de santidade. Foi por meio da fidelidade a ela que os cristãos ganharam o prêmio da vida incorruptível e da glória eterna reservada aos justos, aos santos e aos que guardaram os mandamentos e perseveraram no seu amor - alguns desde o início, outros depois de sua conversão.

Por mais que a Lumen gentium aponte meios e formas para a santidade, Irineu traz uma profundidade na abordagem do tema, pois não desvincilha a vivencia cristã da decisão pela santidade. Ambos estão integrados numa única forma de seguimento do projeto de Jesus Cristo. Para os padres conciliares, por mais que tenham ressaltado a santidade para todos e não somente para os 
consagrados, não se abrem a uma santidade na vida cotidiana, na vivência fraterna na comunidade cristã e na prática da caridade.

O martírio é abordado por Irineu numa perspectiva mais ampla e fundante que a Lumen gentium. Para o bispo de Lião, no martírio não ocorre a morte de uma pessoa, mas sim uma teofania do conteúdo profundo do batismo cristão. A comunhão dos santos é a comunhão dos que trazem a marca, o selo de pertencimento a Cristo, como sigilo da vocação assumida no batismo: ser imagem e semelhança de Deus. Irineu também aproxima o batismo da criação, mostrando que a regeneração batismal, que torna os homens filhos de Deus no Filho Jesus, é a grande obra da recapitulação que o Cristo realizou. Se o ser humano foi criado à imagem e semelhança de Deus, o Cristo recapitula nele esta imagem, na sua entrega total. Ao ser batizado na morte de Cristo para receber a vida, o Espírito sela esse novo nascimento como uma graça fundante.

Na quinta parte, a índole escatológica da Igreja, referente ao sétimo capítulo da Constituição Dogmática sobre a Igreja, os padres conciliares afirmam que a Igreja, peregrina na terra, à qual todos somos chamados, só na glória celeste alcançará a sua realização acabada. Consequentemente, todos os homens e mulheres, a criação completa encontrará em Cristo sua restauração perfeita. Enquanto isto não acontece, a Lumen gentium, reforça que de modo nenhum se interrompe a união dos que ainda caminham sobre a terra com os irmãos que adormeceram na paz de Cristo. Há sim uma comunhão espiritual.

A índole escatológica da Igreja, em Irineu de Lião, é prefigurda na tipologia do povo de Deus em saída do Egito, pois Deus recapitulou pela encarnação do Verbo de Deus toda a criação e no fim, os que constituíram o novo Povo de Deus receberão de Cristo sua herança definitiva. Então, não haverá mais uma Aliança firmada entre homens, que resgata os filhos de Deus; mas o próprio Deus, que armou sua tenda neste mundo, com a encarnação do seu Filho, agregará na Igreja os que são salvos. E ele mesmo, no final dos tempos, reunirá a todos no Reino de seu Pai.

Na sexta e última parte, o capítulo oitavo da Lumen gentium, trata-se da bem-aventurada Virgem Maria no mistério de Cristo e da Igreja. Os padres conciliares colocam Maria dentro do mistério da Igreja, pois ao se tratar do mistério de Cristo, Verbo encarnado, o que se refere a Ele como fonte de todo mistério se refere à beata Virgem Maria; e, ao se falar de Maria, remete-se a 
Cristo como fonte. Ademais, o mesmo mistério continua na Igreja, por meio da qual seus efeitos são aplicados. Sendo assim, a referência é única, o Cristo mistério de Deus. Maria é o coroamento da Constituição Conciliar sobre a Igreja, pois ela, como Mãe de Deus e Mãe do povo de Deus, é o tipo exemplar da Igreja.

Por conseguinte, os padres conciliares refletiram a respeito da doutrina sobre a Mãe de Jesus e sobre a Igreja; sobre a figura de Maria presente na história da salvação atestada pelas Escrituras Sagradas; a função de Maria na economia da salvação; algumas indicações relativas ao culto mariano e à sensibilidade ecumênica; e finalizaram apresentando Maria, a Mãe de Jesus, como sinal do Povo de Deus.

O tema da relação entre Maria e a Igreja é a parte mais deslumbrante e inesperada do capítulo oitavo. A perspectiva é inovadora, pois Maria não é na Igreja um protótipo de poder hierárquico, mas sim modelo de receptividade espiritual diante da graça divina. A relação entre Maria e a Igreja é construída dando preferência ao tema do Povo de Deus, pois a imagem da filha de Sião é personificada na comunidade messiânica, o pequeno grupo que retorna do exílio para Jerusalém.

Comparando a teologia de Irineu em torno do papel da Virgem na economia da salvação do Pai, iniciada pelo Verbo que se encarnou, é ampla e se espalha por todos os seus escritos. Tão significativo que a Constituição Lumen gentium faz uma referência direta à teologia irineana no oitavo capítulo, na segunda parte, quando trata da Virgem Santíssima na economia da salvação.

Numa primeira comparação, Irineu afirma que a encarnação do Verbo de Deus a partir do sim da Virgem foi concreta e não por aparência como defendiam os gnósticos. Um ponto concorde entre a Lumen gentium e Irineu. Para tanto, Irineu aprofunda que seria impossível pensar o plano de salvação de Deus, se não fosse igualando seu Filho à nossa realidade. E Maria, na sua obediência ao projeto de Deus, acolhe este plano de salvação e permite que ele aconteça na sua vida. Deus, ao se utilizar da virgindade e da humanidade de Maria, antítese de Eva, torna-a partícipe da recapitulação que Jesus Cristo realizou.

Irineu apresenta a relação entre Maria e a Igreja, afirmando que Maria canta, no magnificat, em nome do novo Povo de Deus. Ela, como Mãe do Messias, proclama as maravilhas de Deus na sua vida e naqueles que se colocam como seguidores do seu Filho. Em Maria Deus prefigurou uma nova geração, não 
herdada da morte, como fora por Eva, mas herdada da vida que nos vem do Cristo, novo Adão.

Para Irineu Maria não é uma figura a ser exaltada por si mesma, mas pelo exemplo que ela deixou. O sinal da Virgem é o sinal que toda Igreja deve seguir: obediência, atenção à vontade de Deus, disposição em se colocar ao seu serviço, saber ser discípula. A Igreja reflete a luz de Cristo para o mundo, como Maria trouxe o Filho de Deus para a recapitulação. A Igreja precisa aprender de Maria a estar presente e comunicar a presença do Senhor.

A tese consegue chegar às seguintes conclusões:

Primeiramente, no momento em que se deseja retornar às fontes patrísticas para discutir e para produzir a redação definitiva da Lumen gentium existe um germe de aggiornamento que não avança profundamente, visto que os padres conciliares, mesmo desejosos e impulsonados por uma renovação eclesial, não admitem uma eclesiologia unitária, mas, ao invés, produzem um texto fragmentado como resultado de várias opinões e várias intervenções como foi próprio da proposta de um concílio ecumênico. A compreensão de Igreja como mistério e sacramento não rompe com a teologia jurídica e desencarnada da Igreja Corpo Místico de Cristo. Ao mesmo instante, Irineu mostra uma Igreja que nasce na encarnação do Filho de Deus e que se desenvolve na sua vida. Isto não é sinal de Cristo como fundador de um sistema meramente jurídico e institucional, mas sinal da Igreja como um modelo para se inserir na realidade. A eclesiologia irineana se desenvolve da encarnação à parusia, pois o projeto de Deus acontece na existência humana, e abarca o ser humano como um todo. Não um povo, nem uma raça.

Na promessa feita a Abraão surge o grande chamado de Irineu para a Igreja que o Concilio lhe permitiu escutar: "Eu [Deus] farei de ti um grande povo, eu te abençoarei, engrandecerei teu nome" (Gn 12,2). No discurso de Paulo VI, na abertura do segundo período conciliar, ecoa essa busca pela descoberta de Cristo como fundamento e fonte da Igreja. Porém o retorno às fontes cristãs se mantém numa perspectiva espiritual e não real. Não transforma a compreensão da Igreja. Irineu para combater os que desejam espiritualizar a existência humana e sua relação com Deus, contra aqueles que queriam transformar as Sagradas Escrituras somente em mistérios escondidos, e os ritos cristãos em busca pelos mistérios ocultos, afirma a concretude da revelação divina, da encarnação do Filho e da 
graça santificante do Espírito. A existência da Igreja está em Deus e, no seu Filho, ela entende a necessidade de executar a sua missão no mundo.

Um segundo ponto conclusivo aparece no horizonte da comparação entre Irineu e a Lumen gentium, na perspectiva da Igreja como Povo de Deus e do sacerdócio comum dos fiéis, que inaugura na Igreja pós-conciliar um novo horizonte de relação e estruturação eclesial. Na dinâmica litúrgica o Concílio torna a proposta de participação clara pela Sacrosanctum concilium, no horizonte estrutural da comunidade eclesial a mesma participação aparece, na temática do pertencimento ao novo povo de Deus, através do batismo que confere esse múnus de Cristo aos fiéis. Sem desmerecer outras explicações no conjunto da Tese, mas ao olhar para a eclesiologia de Irineu, percebe-se que os padres conciliares foram intimistas na sua revolução. Para Irineu o novo povo de Deus, é prefigurado nos que foram libertos do Egito, mas são salvos na recapitulação que Jesus Cristo empreendeu. Unidos ao Corpo de Cristo pelo batismo, partilham da vida do Cristo. Por conseguinte, o batismo inaugura no fiel essa íntima relação com o Senhor, participando da sua vida, e principalmente da recapitulação que ele empreendeu. A Igreja como povo de Deus, que reúne em si os novo membros regenerados no Cristo, segundo Irineu, muito mais que convocar os cristãos a participarem da comunidade de fé ativamente, convoca a todos os cristãos à tomarem parte da salvação que o Senhor lhes concedeu. Irineu aprofunda a compreensão do novo povo de Deus, pois participam da recapitulação que Jesus Cristo realizou.

Um terceiro ponto é trazido sobre a sucessão apostólica e a colegialidade. Partindo do princípio da comunhão eclesial, Irineu o fundamenta no Espírito Santo que renova e plenifica a Igreja. Assim o ministério episcopal brota de fonte segura e clara, diretamente dos apóstolos, como um rio que nasce no Cristo. Por isso não há nele referência jurídica alguma, pois os bispos são exemplos de vida cristã, de caridade, do seguimento de Cristo, do ensino na regula fidei e da conservação da tradição apostólica. Por mais que a Lumen gentium avance na sacramentalidade do episcopado, a consciência colegial, ainda nasce de um modelo jurídico e de autoridade, como parte da relação com o primado petrino. Para Irineu a cabeça da Igreja é o Cristo e em torno dele todos se reúnem, pois ele também é o corpo, a Igreja. A sucessão emerge do Cristo, enquanto que em comunhão com ele nasce a colegialidade. O bispo de Roma é modelo e 
testemunha de uma igreja que tem origem excelente. Porém o seu poder e sua autoridade estão firmados no Cristo, na tradição da sua igreja e no seu testmunho de vida. Para além de tudo, Irineu defende que o que fundamenta a comunhão eclesial é a consciência de cada cristão, que iluminado pelo Espírito assume sua pertença a Cristo plenamente.

Outra conclusão surgiu na reflexão sobre a presença de Maria no mistério de Cristo e da Igreja. A teologia de Irineu e da Lumen gentium se harmonizam amplamente. Porém neste ponto em que o Concílio conseguiu avançar tão claramente, vencendo o desejo de muitos padres conciliares de exaltarem a Virgem Maria com mais um dogma, o desenvolvimento teológico e o ensino posterior ao Concílio não se debruçaram sobre a profundidade deste tema. A eclesiologia e a mariologia se desenvolvem separadamente nos tempos hodiernos. Sendo assim, a teologia irineana sobre Maria é uma fonte importante para a compreensão da Virgem, vinculada à recapitulação de Cristo e à Igreja. Um aprofundamento na mariologia de Irineu motivaria a teologia contemporânea a uma maior profundidade sobre a presença da Virgem no mistério de Cristo e da Igreja, valorizando ainda mais os avanços conciliares.

Num último ponto, analisando a reflexão do conjunto dos temas eclesiológicos que compõem as partes da Lumen gentium, estes não partem de um projeto pessoal ou de um projeto consciente. Mas partem de escrutínios com vários níveis de convencimento, aceite, rechaço e renúncia dos elementos. Em conseqüência em nenhum momento os padres conciliares pretendem ou demonstram uma unidade temática da Lumen gentium. Quando vão a Irineu ou outra fonte patrística, a abordagem é pontual e de forma acrítica, pois as fontes são escassas e sem um estudo aprofundado.

A eclesiologia de Irineu de Lião como uma fonte de comparação com a Constituição Dogmática Lumen gentium, não emerge com o intuito de uma fonte cristã explicar um texto contemporâneo, pois nem metodologica e nem epistemologicamente isso seria possível. Entretanto o ressourcement abriu aos teólogos e padres conciliares um caminho para encontrarem nas fontes cristãs patrísticas e medievais mais que um texto histórico, isto é, uma fonte de renovação espiritual e teológica. Contudo se percebeu que para usufruir dessas fontes era preciso abordá-las de modo crítico e buscando a hermenêutica do texto. Portanto esta pesquisa conclui que, décadas depois do Concílio, os textos 
patrísticos hoje estudados e analisados criticamente, oferecem um tesouro inenarrável para uma hermenêutica mais aprofundada das propostas conciliares. 


\section{6. Referências Bibliográficas}

ALBERIGO, G. O Vaticano II e sua história. Concilium, v.312, p.7-19, 2005/4.

ALBERIGO, G. (Org.). História dos Concílios Ecumênicos. São Paulo: Paulus, 1995.

ALDAMA, J. A. María en la patrística de los siglos I y II. Madrid: BAC, 1970.

ALDAZÁBAL, J. Gestos e símbolos. São Paulo: Edições Loyola, 2005.

ALDAZÁBAL, J. A Eucaristia. Petrópolis: Editora Vozes, 2012.

ALMEIDA, A. Aggiornamento. In: PASSOS, J.; SANCHEZ, W. (coord.). Dicionário do Concílio Vaticano II. São Paulo: Paulus, 2015, p. 8-9.

ALTANER, B.; STUIBER, A. Patrologia. São Paulo: Paulinas, 1972.

ANDIA, Y. Homo vivens: incorruptibilité et divinisation de l'homme selon Irénée de Lyon. Paris: Études augustiniennes, 1986.

ANDIA, Y. Irénée, théologien l'unité. Nouvelle Revue Théologique, v.109, n.1, p. 3148, 1987. Disponível em: <file:///C:/Users/User/Downloads/irenee-theologien-de-lunite.pdf>. Acesso em: 08 dez. 2020.

ANDIA, Y. L'hérésie et as refutation selon Irénée de Lyon. Augustinianum, v.25, n.3, p. 609-644, dec. 1985.

AYÁn, J. J. Padres Apostólicos. Madrid: Ciudad Nueva, 2012.

BARAÚNA, G. (Org.). A Igreja do Vaticano II. Petrópolis-RJ: Editora Vozes, 1965.

BARBAGLIA, S. Ireneo di Lione e la comunicazione della fede cristiana in una coscienza canonica delle Sacre Scritture. In: CATTANEO, E.; LONGOBARDO, L. (Org.). Consonantía Salutis: studi su Ireneo di Lione. Trapani, Itália: Il pozzo di Giacobbe, 2005, p. 81-158.

BARDY, G. La Théologie de l'Église: de Saint Clément de Rome à Saint Irénée. Paris: Les Éditions du Cerf, 1945.

BARDY, G. La Théologie de l'Église: de Saint Irénée au concile de Nicée. Paris: Les Éditions du Cerf, 1947.

BARRERA, Julio Trebolle. La Biblia judía y la Biblia cristiana. Madri: Editorial Trotta, 2013.

BAZÁN, F. El símbolo Cristiano del pez origen y proyecciones. Scripta Mediaevalia, n.1, p.141-161, 2008. Disponível em: <https://bdigital.uncuyo.edu.ar/objetos_digitales/3762/06-garcia-bazan-scripta-v1-

n1.pdf> Acesso em: 20 abr. 2020.

BEHR, J. Irenaeus of Lyons: identifying christianity. Oxford: Oxford University Press, 2013.

BENOIT, A. Saint Irénée: introduction a l'étude de sa théologie. Paris: Presses Universitaries de France, 1960.

BENOIT, A. Ecriture et Tradition chez saint Irénée. Revue d'Histoire et de Philosophie religieuses, v.40, n.1, p. 32-44, 1960.

BENTO XVI. Discurso do papa Bento XVI aos cardeais, arcebispos e prelados da cúria romana na apresentação dos votos de Natal, 2005. Disponível em: $<\mathrm{http} / / / \mathrm{www}$.vatican.va/content/benedict- 
xvi/pt/speeches/2005/december/documents/hf_ben_xvi_spe_20051222_romancuria.html>. Acesso em: 10 jan. 2021.

BERGAMELLI, F. "Sinfonia" della chiesa nelle lettere di Ignazio di Antiochia. In: FELICI, S. (org.) Ecclesiologia e catechesi patristica. Roma: LAS, 1981, p. 21-80.

BERGER, K. Los primeiros cristianos. Santander-Espanha: Sal Terrae, 2011.

BETTI, U. Relações entre o papa e os outros membros do colégio episcopal. In: BARAÚNA, G. A Igreja do Vaticano II. Petrópolis: Editora Vozes, 1965, p. 789-799.

BOERSMA, H. Nouvelle théologie and sacramental ontology: a return to mystery. Oxford: Oxford University Press, 2009

BRAKKE, D. Los gnósticos: mito, ritual y diversidad en el cristianismo primitivo. Salamanca: Ediciones Sígueme, 2013.

BROW, C.; COENEN, L. Ekklesia. In: BROW, C.; COENEN, L. Dicionário Internacional de Teologia do Novo Testamento. São Paulo: Edições Vida Nova, 2000, v. I, p. 984-998.

BUENO, D. Actas de los mártires. Madrid: BAC, 2012.

CAELLI, A. La vita comune del clero: storia e spiritualitá. Roma: Città Nuova, 2000. Disponível em: <https://books.google.com.br/books?id=buY2k0nAcxEC\&pg=PA33\&lpg=PA33\&dq=la+ concezione+della+chiesa $+\mathrm{in}+\mathrm{s} .+$ clemente+romano+B+Maggioni\&source $=\mathrm{bl} \&$ ots $=\mathrm{i} 24 \mathrm{~S} 1$ N3CfD\&sig=ACfU3U2MT2wbHzkhX0WzwTRy4Q-

B6gDZaA\&hl=it\&sa=X\&ved=2ahUKEwiN473rqMXoAhVSHLkGHZ8rAXsQ6AEwAH oECAoQAQ\#v=onepage $\& \mathrm{q}=\mathrm{la} \% 20$ concezione $\% 20$ della\%20 chiesa\%20in $\% 20 \mathrm{~s} . \% 20 \mathrm{clem}$ ente\%20romano\%20B\%20Maggioni\&f=false >. Acesso em: 31 mar. 2020.

CALABI, F. Fílon de Alexandria. São Paulo: Paulus, 2014.

CALVO, J. J. A. Clemente de Roma: carta a los Corintios. Madrid: Editorial Ciudad Nueva, 1994.

CAMELOT, P. T. Lettres: Ignace d'Antioche et Polycarpe de Smyrne. Paris: Les Éditions du Cerf, 1969, Sources Chrétiennes 10.

CANOBBIO, G. Indole escatológica della Chiesa pellegrinante e sua unione com la Chiesa celeste. In: NOCETI, S.; REPOLE, R. (Orgs.). Commentario ai documenti del Vaticano II: Lumen gentium. Bologna: Edizioni Dehoniane Bologna, 2018, p. 397-421, v.2.

CANOBBIO, G. La beata vergine Maria madre di Dio nel mistero di Cristo e della Chiesa. In: NOCETI, S.; REPOLE, R. (Orgs.). Commentario ai documenti del Vaticano II: Lumen gentium. Bologna: Edizioni Dehoniane Bologna, 2018, p. 423-481, v.2.

CANTALAMESSA, R. Dal kerygma al dogma: studi sulla cristologia dei Padri. Milano: Vita e Pensiero, 2006.

CATtAneO, E.; LONGOBARDO, L. (Org.). Consonantía Salutis: studi su Ireneo di Lione. Trapani, Itália: Il pozzo di Giacobbe, 2005.

CERFAUX, L. As imagens simbólicas da Igreja no Novo Testamento. In: BARAÚNA, G. A Igreja do Vaticano II. Petrópolis: Editora Vozes, 1965, p. 331-345.

CHIAPPARINI, G. Valentino gnostico e platonico: il valentinianesimo della 'Grande notizia' di Irieno di Lione: fra esegesi gnostica e filosofia medioplatonica. Milano: Vita e Pensiero, 2012.

CIPRIANO de Cartago. A oração do Senhor. In: CIPRIANO de Cartago. Obras completas I. São Paulo: Paulus, 2016, p. 157-204.

CLEMENTE de Roma. Carta aos Coríntios. In: PADRES Apostólicos. São Paulo: Paulus, 1995, p. 11-71.

CONGAR, Y. M.-J. A Igreja Povo de Deus. Concilium, v.1, p.8-26, janeiro de 1965. 
CONGAR, Y. M.-J. À guisa de conclusão. In: BARAÚNA, G. A Igreja do Vaticano II. Petrópolis: Editora Vozes, 1965, p.1285-1292.

CONCÍLIO VATICANO II. Constituição dogmática Lumen gentium: sobre a Igreja. 1964.

Disponível

em:

<http://www.vatican.va/archive/hist_councils/ii_vatican_council/documents/vat-

ii_const_19641121_lumen-gentium_po.html>. Acesso em: 8 dez. 2020.

CONCÍLIO VATICANO II. Constituição dogmática Dei verbum: sobre a Revelação divina. $1965 . \quad$ Disponível em: <http://www.vatican.va/archive/hist_councils/ii_vatican_council/documents/vat-

ii_const_19651118_dei-verbum_po.html>. Acesso em: 8 dez. 2020.

CONCÍLIO VATICANO II. Constituição conciliar Sacrosanctum concilium: sobre a sagrada liturgia. $1963 . \quad$ Disponível em: <http://www.vatican.va/archive/hist_councils/ii_vatican_council/documents/vatii_const_19631204_sacrosanctum-concilium_po.html>. Acesso em: 5 jan. 2021.

CONCÍLIO VATICANO II. Declaração Nostra aetate: sobre a Igreja e as religiões não cristãs. $1965 . \quad$ Disponível em: <http://www.vatican.va/archive/hist_councils/ii_vatican_council/documents/vatii_decl_19651028_nostra-aetate_po.html>. Acesso em: 5 mai. 2020.

CONCÍLIO VATICANO II. Declaração Dignitatis humanae: sobre a liberdade religiosa. $1965 . \quad$ Disponível em: <http://www.vatican.va/archive/hist_councils/ii_vatican_council/documents/vatii_decl_19651207_dignitatis-humanae_po.html>. Acesso em: 5 mai. 2020.

COSENTINO, A. Contro le eresie/1: smascheramento e confutazione della falsa gnosi. Roma: Città Nuova Editrice, 2009.

DANIÉLOU, J. La teologia del giudeo-cristianesimo. Bologna: Edizioni Dehoniane Bologna, 1998.

DANIÉLOU, J. La Chiesa dei primi tempi: dalle origini alla fine del III secolo. Torino: Lindau, 2017.

DE LUBAC, H. Liminar. In: BARAÚNA, G. A Igreja do Vaticano II. Petrópolis: Editora Vozes, 1965, p. 27-33

DE LUBAC, H. Cattolicismo: aspetti sociali del dogma. Milano: Editoriale Jaca Book; Lugano: Istituto di Storia della Teologia della Facoltà di Teologia di Lugano, 2017, v.7.

DE LUBAC, H. Paradosso e mistero della chiesa. Milano: Editoriale Jaca Book; Lugano: Istituto di Storia della Teologia della Facoltà di Teologia di Lugano, 2017, v.9.

DE SMEDT, E. O sacerdócio dos fiéis. In: BARAÚNA, G. A Igreja do Vaticano II. Petrópolis: Editora Vozes, 1965, p. 486-498.

DEJAIFVE, G. A colegialidade episcopal na tradição latina. In: BARAÚNA, G. A Igreja do Vaticano II. Petrópolis: Editora Vozes, 1965, p. 860-876.

DONADON, D. B. Adversus haereses, de Irineu de Lyon: tradução e comentários. Campinas, 2011. 146p. Dissertação. Instituto de Estudos da Linguagem, Universidade Estadual de Campinas. Disponível em: <http://repositorio.unicamp.br/jspui/handle/REPOSIP/270759>. Acesso em: $29 \mathrm{dez}$. 2018.

DROBNER, H. R. Manual de Patrologia. Petrópolis-RJ: Editora Vozes, 2003.

ESTRADA, J. A. Para compreender como surgiu a Igreja. São Paulo: Paulinas, 2005.

EUSÉBIO de Cesareia. História Eclesiástica. São Paulo: Paulus, 2000.

FANTINO, J. La théologie d'Irénée: lecture dês Écritures en réponse à l'exégèse gnostique, une approche trinitaire. Paris: Les Éditions du CERF, 1994

FAUS, J. I. G. Carne de Dios: significado salvador de la Encarnación en la teologia de san Ireneo. Barcelona: Editorial Herder, 1969. 
FEINER, J.; LÖHRER, M. (ed.). Mysterium Salutis: Compêndio de Dogmática Histórico-Salvífica. Petrópolis-RJ: Editora Vozes, 1975, v. IV, tomo I, II, III.

FIEDROWICZ, M. Teologia dei Padri della Chiesa: fondamenti dell'antica riflessione cristiana sulla fede. Brescia: Editrice Queriniana, 2010.

FLYNN, G.; MURRAY, P. D. Ressourcement: a movement for renewal in twentiethcentury catholic theology. Oxford: Oxford University Press, 2012.

FORTE, B. A Igreja: ícone da Trindade. São Paulo: Edições Loyola, 2005.

FUENTE, E. B. Eclesiología. Madrid: BAC, 2014.

FÜGLISTER, N. Formas de existência da ekklesia do Antigo Testamento. In: FEINER, J.; LÖHRER, M. Mysterium Salutis: compêndio de dogmática histório-salvífica. Petrópolis: Vozes, 1975, v. IV/1.

GIANOTTI, D. I Padri dela Chiesa al Concilio Vaticano II: la Teologia Patristica nella Lumen gentium. Bologna: Centro editoriale dehoniano, 2010.

GIANOTTI, D. Ressourcement: una teologia dalle fonti. In: VERGOTTINI, M. (org.). Concilio Vaticano II: il balzo innanzi della teologia. Milano: Edizioni Glossa, 2012, p. 19-52.

GIANOTTI, D. Il Vaticano II all'interno della «traditio ecclesiae»: la prospettiva patrística. Rivista di scienze religiose, n.26, p.329-346, 2012. Disponível em: <file:///D:/Il_Vaticano_II_all_interno_della_traditi\%20(1).pdf>. Acesso em: 16 maio 2019.

GIANOTTI, D. I Padri della Chiesa: anima del concilio: il ritorno alle fonti della tradizione patrística e spirituale. Parola e Tempo, n.11, p.50-62, 2012. Disponível em: <file:///D:/I_Padri_della_Chiesa_anima_del_concilio..pdf>. Acesso em: 16 maio 2019.

GILSON, E. A Filosofia na Idade Média. São Paulo: WMF Martins Fontes, 2013

GIRARDI, L. Sacrosanctum concilium. In: NOCETI, S.; REPOLE, R. Commentario ai documenti del Vaticano II: Sacrosanctum concilium e Inter mirifica. Bologna: Edizioni Dehoniane Bologna, 2018, p. 81-300, v. 1.

GONÇALVES, P.; PIACENTE, L., Antropologia espiritual de Irineu de Lião. Teocomunicação, v.47, n.1, p. 39-50, jan./jun. 2017.

GRANADO, C. El Espiritu Santo en la teologia patristica. Salamanca: Ediciones Sigueme, 1987.

GRASSO, D. I carismi nella Chiesa antica. Augustinianum, v.20, n.3, p. 671-686, dec. $1980 . \quad$ Disponível em: <https://www.pdenet.org/agstm/content/agstm_1980_0020_0003_0671_0686>. Acesso em: 8 mai. 2020.

GRILLMEIER, A. Gesù il Cristo nella fede della Chiesa: dall'età apostolica al concilio di Calcedonia (451). Brescia: Paideia Editrice, 1982, v. I/I

GROSSI, V. Linee di ecclesiologia patrística: il formarsi della coscienza di 'Chiesa' nei primi sette secoli. Roma: Edizioni Borla, 2014.

GROSSI, V.; DI BERNARDINO, A. La chiesa antica: ecclesiologia e istituzioni. RomaItália: Ed. Borla, 1984.

GUARDUCCI, M. L'iscrizione di Abercio e Roma. Ancient Society, vol. 2, p.174-203, 1971. Disponível em: <https://www.jstor.org/stable/44080036?readnow=1\&seq=1\#page_scan_tab_contents $>$. Acesso em: 20 abr 2020.

HAMMAN, A.-G. Saint Irénée et la priére. In: POSE, E. R. (ed.) Pléroma: salus carnis. Santiago de Compostela: [s.n.], 1990, p. 307-319.

HELLÍN, F. G. (Org.). Constitutio dogmatica de Ecclesia Lumen gentium: Concilii Vaticani II synopsis. Vaticano: Libreria Editrice Vaticana, 1995.

HERMAS. O Pastor. In: PADRES Apostólicos. São Paulo: Paulus, 1995, p. 161-276. 
HOUSSIAU, A., Le baptêmê selon Irénée de Lyon. Ephemerides Theologicae Lovanienses, v.60, n.1, p. 45-59, 1984.

INÁCIO de Antioquia. Cartas. In: PADRES Apostólicos. São Paulo: Paulus, 1995, p. 73128.

IPARRAGUIRRE, I. Natureza da santidade cristã e meios para consegui-la. In: BARAÚNA, G. A Igreja do Vaticano II. Petrópolis: Editora Vozes, 1965, p. 1069-1084. IRÉNÉE de Lyon. Contre les hérésies: livre I. Paris: Les Éditions du Cerf, 2008, tome I. Sources chrétiennes 263.

IRÉNÉE de Lyon. Contre les hérésies: livre I. Paris: Les Éditions du Cerf, 1979, tome II. Sources chrétiennes 264.

IRÉNÉE de Lyon. Contre les hérésies: livre II. Paris: Les Éditions du Cerf, 1982, tome I. Sources chrétiennes 293.

IRÉNÉE de Lyon. Contre les hérésies: livre II. Paris: Les Éditions du Cerf, 1982, tome II. Sources chrétiennes 294.

IRÉNÉE de Lyon. Contre les hérésies: livre III. Paris: Les Éditions du Cerf, 1974, tome I. Sources chrétiennes 210.

IRÉNÉE de Lyon. Contre les hérésies: livre III. Paris: Les Éditions du Cerf, 1974, tome II. Sources chrétiennes 211.

IRÉNÉE de Lyon. Contre les hérésies: livre IV. Paris: Les Éditions du Cerf, 1965, tome I. Sources chrétiennes 100.

IRÉNÉE de Lyon. Contre les hérésies: livre IV. Paris: Les Éditions du Cerf, 1965, tome II. Sources chrétiennes 100.

IRÉNÉE de Lyon. Contre les hérésies: livre V. Paris: Les Éditions du Cerf, 1969, tome I. Sources chrétiennes 152.

IRÉNÉE de Lyon. Contre les hérésies: livre V. Paris: Les Éditions du Cerf, 1969, tome II. Sources chrétiennes 153.

IRÉNÉE de Lyon. Démonstration de la prédication apostolique. Paris: Les Éditions Du Cerf, 1995.

IRENEO di Leone. Contro le eresie: smascheramento e confutazione della falsa gnosi. Roma: Città Nuova Editrice, 2009, v. I.

IRENEO di Leone. Contro le eresie: smascheramento e confutazione della falsa gnosi. Roma: Città Nuova Editrice, 2009, v. II.

IRINEU de Lião. Contra as heresias: denúncia e refutação da falsa gnose. São Paulo: Paulus, 2013.

IRINEU de Lião. Demonstração da pregação apostólica. São Paulo: Paulus, 2014.

JOÃO XXIII. Discurso de sua santidade papa João XXIII na abertura solene do Santíssimo Concílio. 1962. Disponível em: <http://w2.vatican.va/content/johnxxiii/pt/speeches/1962/documents/hf_j-xxiii_spe_19621011_opening-council.html>.

Acesso em: 04 maio 2019.

JOSSA, G. Regno di Dio e Chiesa: ricerche sulla concezione escatológica ed ecclesiologica dell'Adversus haereses di Ireneo di Lione. Napoli: M. d'Auria Editore Pontificio, 1970.

JUSTINO de Roma. I e II Apologias; Diálogo com Trifão. São Paulo: Paulus, 1995.

KASPER, W. A Igreja Católica: essência, realidade, missão. São Leopoldo: Editora Unisinos, 2012.

KEHL, M. A Igreja: uma eclesiologia católica. São Paulo: Edições Loyola, 1997.

KLOPPENBURG, B. As vicissitudes da Lumen gentium na aula conciliar. In: BARAÚNA, G. A Igreja do Vaticano II. Petrópolis: Editora Vozes, 1965, p. 194-251. 
LABOURDETTE, M. A santidade, vocação de todos os membros da Igreja. In: BARAÚNA, G. A Igreja do Vaticano II. Petrópolis: Editora Vozes, 1965, p.1057-1068.

LAITI, G. La Chiesa nell'economia di Dio secondo Ireneo di Lione. In: CATTANEO, E.; LONGOBARDO, L. (Org.). Consonantía Salutis: studi su Ireneo di Lione. Trapani, Itália: Il pozzo di Giacobbe, 2005, p. 159-178.

LAMELAS, I. P. Sim, cremos: o credo comentado pelos Padres da Igreja. Lisboa: Universidade Católica Editora, 2013.

LAMELAS, I. P. As origens do Cristianismo: Padres Apostólicos. Lisboa: Paulus Editora, 2016.

LAYTON, B. As escrituras gnósticas. São Paulo: Edições Loyola, 2002.

LE GUILLOU, M.-J. A vocação missionária da Igreja. In: BARAÚNA, G. A Igreja do Vaticano II. Petrópolis: Editora Vozes, 1965, p. 713-728.

LIBÂNIO, J. B. Concílio Vaticano II: em busca de uma primeira compreensão. São Paulo: Edições Loyola, 2005.

LIÉBAERT, J. Os Padres da Igreja: séculos I-IV. São Paulo: Edições Loyola, 2000, v.1.

LOPES, G. Patrística pré-nicena. São Paulo: Paulinas, 2014.

LOPES, G. Lumen gentium: texto e comentário. São Paulo: Paulinas, 2011.

MAGGIONI, Bruno. La concezione della Chiesa in S. Clemente Romano. Studia Patavina, v.13, p.3-27, 1966.

MAIA, G. A soteriologia ireneana e seu influxo na constituição "Gaudium et spes" como relevância para a acolhida da salvação na alta modernidade. Roma, 2013. 409p. Tese. Programa de pós-graduação da Faculdade de Teologia, Pontifícia Universidade Gregoriana

MAZZOLINI, S. Vocazione universale alla santità nella Chiesa. In: NOCETI, S.; REPOLE, R. (Orgs.). Commentario ai documenti del Vaticano II: Lumen gentium. Bologna: Edizioni Dehoniane Bologna, 2018, p. 355-375, v. 2.

MELITONE di Sardis. Omelia sulla Santa Pasqua. Disponível em: $<\mathrm{http} / / / \mathrm{www}$. notedipastoralegiovanile.it/index.php?option=com_content\&view=article\&i $\mathrm{d}=13614$ :omelia-sulla-santa-pasqua-melitone-di-sardi\&catid=170\&Itemid=1227> .

Acesso em: 21 abr. 2020.

MORESCHINI, C.; NORELLI, E. História da Literatura Cristã Antiga grega e latina I: de Paulo à era Constantiniana. São Paulo: Edições Loyola, 1996, v.I.

MOTTA, S. A. Eclesiologia nas cartas de santo Inácio de Antioquia. Revista de Cultura Teológica, n.16, p. 121-125, 1996.

NOCETI, S. La costituzione gerarchica della Chiesa e in particolare l'episcopato. In: NOCETI, S.; REPOLE, R. (Orgs.). Commentario ai documenti del Vaticano II: Lumen gentium. Bologna: Edizioni Dehoniane Bologna, 2018, p. 209-314, v. 2.

NOCETI, S.; REPOLE, R. (Org.). Commentario ai documenti del Vaticano II: Lumen gentium. Bologna: Centro editoriale dehoniano, 2018, v. 2.

O'MALLEY, J. W. Volta às fontes e reforma no Vaticano II. Concilium, v.346, p.48-57, 2012/3.

OÑATIBIA, I. Batismo e confirmação: sacramentos de iniciação. São Paulo: Paulinas, 2007.

ORBE, A. Antropología de San Ireneo. Madrid: BAC, 1969.

ORBE, A. Espiritualidad de San Ireneo. Madrid: BAC, 2015.

ORBE, A. Introduccion a la teologia de los siglos II y III. Salamanca: Sigueme, 1988.

ORBE, A. Parábolas evangélicas en San Ireneo. Madrid: BAC, 2015.

ORBE, A. Teología de San Ireneo I: comentario al Libro V Del "Adversus haereses". Madrid: BAC, 1985. 
ORBE, A. Teología de San Ireneo II: comentario al Libro V Del "Adversus haereses". Madrid: BAC, 1987.

ORBE, A. Teología de San Ireneo III: comentario al Libro V Del "Adversus haereses". Madrid: BAC, 1988.

ORBE, A. Teología de San Ireneo IV: traducción y comentario al Libro IV Del "Adversus haereses". Madrid: BAC, 1994.

ORBE, A. Ecclesia, sal terrae, según san Ireneo. Recherches de Science Religieuse, v.60, p. 219-240, 1972.

ORBE, A., Gli apocrifi cristiani a Nag Hammadi. Augustinianum, v.23, p. 83-109, 1983.

OSBORN, E. Irenaeus of Lyons. New York: Cambridge UniversitY Press, 2001.

PADRES Apostolicos. Madrid: BAC, 1965.

PADRES Apostólicos. São Paulo: Paulus, 1995.

PADRES Apostólicos. Madrid: Ciudad Nueva, 2012.

PADRES Apologistas. São Paulo: Paulus, 1995.

PAULO VI. Discurso do papa Paulo VI na solene inauguração da $2^{\text {a }}$ sessão do Concílio Vaticano II. 1963. Disponível em: <http://www.vatican.va/content/paulvi/pt/speeches/1963/documents/hf_p-vi_spe_19630929_concilio-vaticano-ii.html>.

Acesso em: 12 dez. 2020.

PAULO VI. Discurso do papa Paulo VI na inauguração da terceira sessão do Concílio Ecumênico Vaticano II. 1964. Disponível em: <http://www.vatican.va/content/paul-vi/pt/speeches/1964/documents/hf_p-

vi_spe_19640914_III-sessione-conc.html >. Acesso em: 12 dez. 2020.

PAULO VI. Carta encíclica Ecclesiam suam. 1964. Disponível em: <http://www.vatican.va/content/paul-vi/pt/encyclicals/documents/hf_pvi_enc_06081964_ecclesiam.html >. Acesso em: 13 dez. 2020.

PERETTO, E. Ireneo di Lione. In: SODI, M.; RONZANI, R. La predicazione nei Padri della Chiesa: una tradizione sempre attuale. Città del Vaticano: Lateran University Press, 2017, p. 215-226.

PERETTO, E. Epideixis, antico catechismo degli adulti. Roma: Borla, 1981.

PHILIPON, M. A Santíssima Trindade e a Igreja. In: BARAÚNA, G. A Igreja do Vaticano II. Petrópolis: Editora Vozes, 1965, p. 361-383.

PHILIPS, G. A Igreja e seu mistério no II Concílio do Vaticano: história, texto, comentário da Constituição Lumen gentium. São Paulo: Editora Herder, 1968, tomo I.

PHILIPS, G. La chiesa e il suo mistero: storia, testo e commento della "Lumen gentium". Milano: Jaca Book, 1975

PIACENTE, L. O encontro do cristianismo com a cultura clássica: a questão em Irineu de Lião. Campinas, 2016. 159p. Dissertação. Programa de Pós-Graduação em Ciências da Religião, Pontifícia Universidade Católica de Campinas.

PIÉ-NINOT, S. Eclesiología: la sacramentalidad de la comunidad cristiana. Salamanca: Ediciones Sígueme, 2015.

PIETRI, C. L'ecclésiologie patristique et Lumen gentium. In: LE DEUXIÈME concile du Vatican (1959-1965). Roma: Ecole Française de Rome, p. 511-537, 1989. Disponível em: 〈https://www.persee.fr/doc/efr_0000-0000_1989_act_113_1_3389>. Acesso em: 29 dez. 2018.

PIO XII. Carta encíclica Mystici corporis. 1943. Disponível em: $<$ http://www.vatican.va/content/pius-xii/pt/encyclicals/documents/hf_pxii_enc_29061943_mystici-corporis-christi.html>. Acesso em: 12 dez. 2020.

PLAGNIEUX, J. La doctrine mariale de Saint Irénée. In: LE DEUXIÈME concile du Vatican (1959-1965). Roma: Ecole Française de Rome, p. 179-189, 1989. Disponível 
em: <https://www.persee.fr/doc/efr_0000-0000_1989_act_113_1_3389>. Acesso em: 29 dez. 2018.

POSE, E. R. La siembra de los Padres. Madrid:Publicaciones San Damaso, 2010.

POSE, E. Pensamiento teológico de san Ireneo de Lion. El gnosticismo, madre de todas las sectas. In: POSE, E. R. La siembra de los Padres. Madrid: Publicaciones San Damaso, 2010, p. 583-600.

POSE, E. R. Ireneo de Lión. Demostración de la precicación apostólica. Madrid: Editorial Ciudad Nueva, 1992.

PRINZIVALLI, E.; SIMONETTI, M. La teologia degli antichi cristiani (secoli I-V). Brescia: Editrice Morcelliana, 2015.

QUASTEN, J. Patrologia I: hasta el concilio de Nicea. Madrid: BAC, 2004.

RAHNER, H. Simboli della Chiesa: l'ecclesiologia dei Padri. Milano: Edizioni San Paolo, 1995.

RÄISÄNEN, H. El nacimiento de lãs creencias cristianas. Salamanca: Ediciones Sígueme, 2011.

RATZINGER, J. Iglesia, signo entre los pueblos: escritos sobre eclesiologia y ecumenismo. Madrid: BAC, 2015, v. VIII/1.

RATZINGER, J. A colegialidade episcopal. In: BARAÚNA, G. A Igreja do Vaticano II. Petrópolis: Editora Vozes, 1965, p. 763-788.

REPOLE, R. Il mistero della Chiesa. In: NOCETI, S.; REPOLE, R. (Orgs.). Commentario ai documenti del Vaticano II: Lumen gentium. Bologna: Edizioni Dehoniane Bologna, 2018, p. 79-142, v. 2.

RIBEIRO, A. L. V. Demonstração da pregação apostólica. São Paulo: Paulus, 2014.

RIBEIRO, H. Contras as Heresias: denúncia e refutação da falsa gnose. São Paulo: Paulus, 2013.

ROUSSEAU, A. Démonstration de la prédication apostolique. Paris: Les Éditions du Cerf, 1995.

ROUSSEAU, A.; DOUTRELEAU, L. Contre lês hérésies: livre 1. Paris: Les Éditions du Cerf, 2008.

ROUTHIER, G. Les accents ecclésiologiques du pontificat du pape François: une mise em oeuvre originale de Lumen gentium. Atualidade teológica, v.20, n.54, p.549-563, set./dez. 2016.

ROUTHIER, G. Introduzione alla costituzione dogmatic Lumen gentium. In: NOCETI, S.; REPOLE, R. (Orgs.). Commentario ai documenti del Vaticano II: Lumen gentium. Bologna: Edizioni Dehoniane Bologna, 2018, p. 13-78, v. 2.

SCHERRER, T. La gloire de Dieu dans l'oeuvre de Saint Irénée. Roma: Editrice Pontificia Università Gregoriana, 1997.

SCHILLEBEECKX, E. Cristo, sacramento do encontro com Deus. Petrópolis: Editora Vozes, 1967.

SCHILLEBEECKX, E. Por uma Igreja mais humana: identidade cristã dos ministérios. São Paulo: Edições Paulinas, 1989.

SCHLIER, H. A eclesiologia do Novo Testamento. In: FEINER, J.; LÖHRER, M. Mysterium Salutis: compêndio de dogmática histório-salvífica. Petrópolis: Vozes, 1975, v.IV/1.

SCORDAMAGLIA, D. Ritratti di Cristo in Sant'Ireneo. Bologna: Edizioni Dehoniane Bologna, 2015.

SEMERARO, M. Collegialità episcopale e primato al Vaticano II. In: TANGORRA, G. (ed.). La Chiesa, mistero e missione: a cinquant'anni dalla Lumen gentium (1964-2014). Roma: Lateran University Press, 2016, p. 135-152. 
SEMMELROTH, O. A Igreja, novo Povo de Deus. In: BARAÚNA, G. A Igreja do Vaticano II. Petrópolis: Editora Vozes, 1965, p. 471-485.

SESBOÜÉ, B. L'acte théologique d'Irénée de Lyon à Karl Rahner: les grandes créations en théologie chrétienne. Paris: Éditions jésuites, 2017.

SESBOÜÉ, B. Tout récapituler dans le Christ: christologie et sotériologie d'Irénée de Lyon. Paris: Desclée, 2000.

SESBOÜÉ, B. O Espírito na Igreja. Concilium, v.342, p.66-74, 2011/4.

SILVA, A. L. R. A comunidade de São Justino mártir em Roma: a escolarização da comunidade cristã como critério de distinção eclesiástica. Roma, 2012. 240p. Tese. Institutum Patristicum Augustinianum, Pontificia Universitas Lateranensis.

SILVA, V. S. Ecclesia sicuti "unitate Patris et Filii et Spiritus Sancti”: aspectos de eclesiologia de comunhão da liturgia e nos Santos Padres. Teocomunicação, v.42, n.2, p. 242-258, jul./dez. 2012. Disponível em: <file:///C:/Users/User/Downloads/12305-457001-PB.pdf >. Acesso em: 18 abr. 2020.

SIMONETTI, M. Il vangelo e la storia: il cristianesimo antico (secoli I-IV). Roma: Carocci editore, 2015.

SIMONETTI, M. Lettera e/o allegoria: un contributo alla storia dell'esegesi patristica. Roma: Institutum Patristicum Augustinianum, 1985.

SINGLES. D. A glória de Deus é o homem vivo: a profissão de fé de Santo Irineu. São Paulo: Paulus, 2010.

SINISCALCO, P. Il cammino di Cristo nell'Impero romano. Roma: Editori Laterza, 2009.

SMULDERS, P., A Igreja como sacramento de salvação. In: BARAÚNA, G. A Igreja do Vaticano II. Petrópolis: Editora Vozes, 1965, p. 396-419.

SOTOMAYOR, M.; UBIÑA, J. F. (Orgs.). Historia del cristianismo: el mundo antiguo. Madrid: Editorial Trotta, 2011, v. I.

SPIKOWSKI, L. La doctrine de l'Église dans Sanit Irénée. Strasbourg, 1926.161p. Tese. Faculté de Théologie Catholique, Université de Strasbourg.

STEGEMANN, E. W.; STEGEMANN, W. História social do protocristianismo: os primórdios no judaísmo e as comunidade de Cristo no mundo mediterrâneo. São Paulo: Paulus; São Leopoldo: Sinodal, 2004.

STORNIOLO, I; BALANCIN, E., Padres apostólicos. São Paulo: Paulus, 1995.

SYKES, A. S. Melito anti' judaism. Journal of Early Christian Studies, v.5, n.2, p. 271283, 1997. Disponível em: <https://muse.jhu.edu/article/9873/summary>. Acesso em: 19 mai. 2020.

TANGORRA, G. (ed.). La Chiesa, mistero e missione: a cinquant'anni dalla Lumen gentium (1964-2014). Roma: Lateran University Press, 2016.

TREVIJANO, R. A Bíblia no cristianismo antigo: pré-nicenos, gnósticos, apócrifos. São Paulo: Editora Ave-Maria, 2009, v. 10.

TRISOGLIO, F. Dalla Pasqua ebraica a quella cristiana in Melitone di Sardi. Augustinianum, v.28, p.151-185, aug. 1988. Disponível em: <https://www.pdcnet.org/agstm/content/agstm_1988_0028_0001_0151_0185>. Acesso em: 20 abr. 2020.

VITALI, D. Lumen gentium: storia/commento/recezione. Roma: Edizioni Studium, 2017.

VITALI, D. Il popolo di Dio. In: NOCETI, S.; REPOLE, R. (Orgs.). Commentario ai documenti del Vaticano II: Lumen gentium. Bologna: Edizioni Dehoniane Bologna, 2018, p. 143-208, v. 2.

WIEDENHOFER, S. Eclesiologia. In: SCHNEIDER, T. Manual de dogmática. Petrópolis: Editora Vozes, 2012, p. 50-142. 
ZOGHBY, E. Unidade e diversidade da Igreja. In: BARAÚNA, G. A Igreja do Vaticano II. Petrópolis: Editora Vozes, 1965, p. 557-576. 